\title{
De waarde van PiPS voor de Nederlandse Bouwsector verklaard
}

Inleiding op de Openbare Verdediging Joop van Duren

5 juni 2013

Twente University 
De waarde van pips voor de Nederlandse Bouwsector verklaard 


\title{
promotiecommisie
}

\author{
Voorzitter secretaris prof.dr. F. Eising Universiteit Twente \\ Promotor prof.dr.ir. A. G. Dorée Universiteit Twente \\ Leden prof.mr.dr. C.E.C Jansen Vrije Universiteit Amsterdam \\ dr.drs.ir. C.M. Ravesloot Hogeschool Rotterdam \\ prof.mr.dr.ir. S.C. Santema Technische Universiteit Delft \\ prof.dr. Telgen Universiteit Twente \\ dr. J. T. Voordijk Universiteit Twente
}

Titel

De waarde van pips voor de Nederlandse

Bouwsector verklaard.

Auteur

ISBN

Joop van Duren

978-90-365-3531-1

Grafisch ontwerp

Studio Sanne Gijsbers

DOI

10.3990/1.9789036535311

Drukkerij

Drukkerij Tielen 
DE WAARDE VAN PIPS VOOR DE NEDERLANDSE BOUWSECTOR VERKLAARD

\section{PROEFSCHRIFT}

ter verkrijging van

de graad van doctor aan de Universiteit Twente, op gezag van de rector magnificus,

prof.dr. H. Brinksma

volgens besluit van het College voor Promoties

in het openbaar te verdedigen

op woensdag 5 juni 2013 om 16.45 uur

door

Joseph Maria Antonius van Duren geboren op 2 september 1959

te Heerlen 

information Procurement System (PiPs). Deze methode om 'anders' aan te besteden heeft me vanaf de eerste kennismaking geïntrigeerd. In een notendop komt pips op het volgende neer:

Daag marktpartijen uit door bij de uitvraag een oplossingsvrij geformuleerde vraagstelling te hanteren, en geef daarbij aan wat het maximale budget is dat besteed kan worden aan de gevraagde functionaliteiten. Verzamel en gebruik vervolgens informatie over de performance van inschrijvers uit het verleden. Richt een proces in om inschrijvers te kunnen ranken, zowel wat betreft hun performance op in het verleden uitgevoerde projecten, als voor wat betreft hun vermogen om het huidige project succesvol te kunnen realiseren. Besteed daarbij aandacht aan prijs, kwaliteit van sleutelfunctionarissen, kwaliteit van de oplossing, en aan het inzicht in de aan het aan te besteden project verbonden risico's en de manier waarop men denkt die te managen. Draag projectrisico's over aan de aannemer, zodat deze 'gedwongen' wordt deze risico's ook daadwerkelijk te managen en te minimaliseren. Sta de gecontracteerde aannemer toe de eigen 'performance' te managen en te monitoren, gebaseerd op het minimaliseren van risico's. Volg de prestaties van de gecontracteerde aannemer op kritische punten, en beoordeel de prestaties met het oog op eventuele toekomstige projecten.

In de loop van 2003 heb ik een voorstudie over pips uitgewerkt en met Dean Kashiwagi kunnen bespreken, in 2004 en 2005 hebben enkele bachelor- en master studenten (onder mijn leiding) deelonderzoeken naar de werking ervan uitgevoerd. In 2005 bestonden er serieuze plannen pips voor het eerst in Nederland toe te passen waarbij ik een 
leidende rol zou vervullen. Vandaar dat ik in februari 2005 de jaarlijkse 'Best Value Conference' in Phoenix, Arizona heb bijgewoond.

$\mathrm{Al}$ deze activiteiten riepen een aantal vragen bij mij op. Met name omdat de pips methodiek tot opmerkelijke resultaten leidt, terwijl de verklaring daarvoor, zoals Kashiwagi die ziet, in mijn ogen smal is. Ik wilde deze methodiek, waarvan ik 'het gevoel' had dat hij werkt, wetenschappelijk verklaren en onderbouwen. Uiteindelijk leidde die drang tot dit proefschrift. Met dank aan André Dorée die me 'dwong' om mijn vragen en ambitie dusdanig te vertalen dat ik helder kon formuleren wát ik wilde onderzoeken, waaróm ik dat wilde en waartoe dat zou moeten leiden. Uiteindelijk bracht me dat bij:

"Het is toch te gek dat er geen bevredigende verklaring voor de werking van pips bestaat."

Verder wilde ik het onderzoek naar de bruikbaarheid van deze methodiek beperken tot het bouwdomein. Deze afbakening werd ingegeven doordat de roep naar 'anders aanbesteden' het meest prominent in de bouwsector speelde. Vandaar de titel van mijn proefschrift:

"De waarde van pips voor de Nederlandse Bouwsector verklaard."

De meeste promovendi zullen het woekeren met de beschikbare tijd en de verdeling daarvan herkennen en onderschrijven. Daarop vorm ik geen uitzondering. Dit ondanks mijn geluk dat mijn werkgever, Zuyd Hogeschool, dit onderzoek in tijd heeft gefaciliteerd. Waarvoor mijn hartelijke dank!

Mijn focus op enerzijds dit wetenschappelijk onderzoek en anderzijds de meer op de praktijk gerichte нво wereld, vroeg om spankracht en flexibiliteit.

Dit onderzoek heeft me verrijkt. Het verschafte me nieuwe inzichten in de wetenschap en haar methodologische werkwijzen en haar typische idioom. Het gaf me een betere kijk op 'de bouw' in Nederland en op aanbesteden. Daarnaast heb ik ontdekt dat theorievorming gebaat is bij een streng methodologisch regime en dat een zeker abstractieniveau gekoppeld aan het 'spelen met distantie', voorwaarde is om tot nieuwe inzichten te komen.

Ik heb de boeiende wereld van het aanbesteden mogen ontdekken en steeds beter leren begrijpen. Uitgebreide internationale literatuurstudie maakte duidelijk dat zowel opdrachtgevers als opdrachtnemers uitzien naar het doorbreken van de traditionele en versnipperde aanpak. Die leidt blijkbaar te vaak tot teleurstelling aan beide zijden.

$\mathrm{Nu}$ ik de pips werkwijze in beeld heb, de werking ervan kan verklaren en ook heb kunnen ervaren en constateren dat er goede mogelijkheden zijn om de meeste werkzame elementen in de Nederlandse Bouw toe te kunnen passen, heb ik de overtuiging dat dit promotie onderzoek niet alleen mijzelf verrijkt heeft, maar -en dat is vele malen belangrijkerstructureel en systematisch kan bijdragen aan het verbeteren van aan bestedingen en het vergroten van de kans op projectsucces van eenmaal aanbestede werken. En daarmee kan bijdragen tot professionalisering van de sector.

Tijdens dit onderzoek heb ik de hulp en medewerking van vele mensen en organisaties mogen ervaren. Op het gevaar af mensen tekort te doe door ze hier niet te noemen, wil ik toch een aantal mensen en organisaties in het bijzonder noemen.

Dean Kashiwagi en John Savicky (beiden van Arizona State University Performance Based Studies Research Group) voor het beantwoorden van vele vragen, het ter beschikking stellen van projectdata en het op afstand beschikbaar zijn voor het geven van adviezen bij de praktijkcases. PSiBouw en Regieraad Bouw voor het faciliteren (lees toekennen van subsidie aan project i401) van het vooronderzoek dat ik in 2005 en 2006 heb mogen uitvoeren onder auspiciën van Lector Mark Erik Nota (Lectoraat FMInnovation; Zuyd, Saxion, HU, 2003 - 2007).

UMC St Radboud (in de personen van Felix van Baal, directeur Bedrijf Huisvesting en de projectmanagers Jan Bijl, René de Weger, contractmanager Lia Mur) voor het bieden van de mogelijkheden pips toe te passen bij enkele 'live' aanbestedingen ( 3 onderhoudsprojecten, nieuwbouw parkeergarage en Fase III van de vernieuwing van de UMC Campus). Rijkswaterstaat in de personen van Mark Eichner en Wiebe Witteveen voor het bieden van de mogelijkheid om mee te denken bij de voorbereidingen voor het daadwerkelijk toepassen van (delen van) pips bij het aanbesteden van concrete projecten, tevens voor het ter beschikking stellen van een grote hoeveelheid e-mail 
adressen van projectleiders voor het kwantitatieve deel van dit onderzoek. De gemeente 's-Hertogenbosch en Breijn (respectievelijk vertegenwoordigd door Albert Oostra en Gard van Hulzen) voor het bieden van de mogelijkheid een bijdrage te leveren aan de inrichting en uitvoering van het aanbestedingstraject voor het aanleggen van een bergbezinkbassin. Sanne Gijsbers heeft de vormgeving en opmaak van dit proefschrift voor haar rekening genomen, waarvoor hartelijk dank Sanne!

André Dorée is zo'n zeven jaar mijn gids geweest. Zoals dat past in een promotieonderzoek heb ik veel zelf moeten uitzoeken, maar op cruciale punten kon ik altijd bij André terecht voor een doortastende tegenvraag, kritische feedback, het tonen van andere (inderdaad

interessantere) routes waarvoor mijn welgemeende dank.

Christoph Maria Ravesloot (tot eind 2011 Lector bij Zuyd Hogeschool) heeft vanaf begin 2009 een rol gespeeld bij de dagelijkse begeleiding. Zijn relativeringsvermogen, soms onorthodoxe werkwijzen en netwerk zijn daarbij voor dit onderzoek waardevol gebleken.

De gesprekken met de leden van de promotiecommissie zijn inspire-

rend geweest en hebben tot zinvolle aanscherpingen geleid.

Behalve naar promotor prof. dr. ir. A.G. Dorée gaat mijn dank in dit verband ook uit naar prof. dr. J. Telgen, Prof. mr. dr. ir. S.C. Santema, prof. mr. dr. C.E.C. Jansen, dr. J.T. Voordijk en dr. drs. ir. C.M Ravesloot. Ook de feedback met betrekking tot het kwantitatieve onderzoek van prof. dr. C.C.P. Snijders heeft tot waardevolle aanscherpingen geleid. Deze gesprekken hebben onder andere geleid tot het herstructureren en 'indikken' van het proefschrift en het aanscherpen, focussen van de inhoud ervan. Niet altijd makkelijk om over de eigen schaduw heen te stappen, maar achteraf wel erg nuttig. Dank daarvoor!

Ook zijn er een aantal dingen tegengevallen en/of niet helemaal gelopen als gewenst. Die deel ik hier graag met u. Kierkegaard, een $19^{e}$ eeuwse Deense filosoof, schreef dat het leven alleen achterwaarts begerepen kan worden, maar dat het slechts voorwaarts geleefd kan worden.

Een parallel met het doen van promotieonderzoek dringt zich op. Ik kom herhaaldelijk inzichten tegen die op dat moment nog niet doorgrond worden, het belang ervan nog onvoldoende doorzien. Verderop kon ik dat wel duiden. Zo ontstaat de spreekwoordelijke Echternachter processie. Na twee stappen voorwaarts, moet regelmatig een stap terug gezet worden. Een onderzoek als dit moet doorleefd en doorgemaakt worden.

De afgelopen zeven jaren ben ik soms intensief, bij tijd en wijlen minder indringend met dit onderzoek bezig geweest. Dat is duidelijk langer dan ik oorspronkelijk voorzien had. De tijd die nodig is voor het uitvoeren van onderzoek dat ten grondslag ligt aan dit proefschrift enerzijds, en het 'opschrijven' ervan anderzijds, staat achteraf bezien, in een heel andere verhouding dan aanvankelijk gedacht. Met andere woorden, ik heb een langere weg af moeten leggen om deze 'meesterproef' af te leveren dan ik op voorhand dacht. Dat verklaart voor een deel dat minder aan heel recente bronnen wordt gerefereerd; de meeste delen van het onderzoek zijn tot en met 2009 uitgevoerd. Ook heb ik onmisbare hulp gehad in de vorm van tips, adviezen, een luisterend oor, wegwijs maken in een softwarepakket, het tegenlezen van concepten etc. Danielle, Jack, Maarten, Ad, Ria, Peter, Monique, Mirjana, Jessie, Clint, Sjef, Ger: dank jullie wel. Ook dank aan Ad Smit en Roel Hamers (respectievelijk faculteitsdirecteur en opleidingscoördinator) die er in zijn blijven geloven dat mijn promotieonderzoek tot een goed einde zou geraken.

Gedurende de eerste jaren van dit onderzoek zijn enkele master en bachelor studenten ingezet. Andries van Bentum heeft de resultaten van de Amerikaanse pips projecten tegen het licht gehouden en Moniek Faassen heeft als een soort van projectsecretaris het verloop van enkele Pips aanbestedingen bij het UMC St Radboud gedocumenteerd en gemonitord. Jullie bijdragen hebben me flink geholpen, beiden van harte bedankt hiervoor.

Last but not least het thuisfront: Dit onderzoek heeft de afgelopen jaren een deel van me opgeslokt. Dat uitte zich in het benutten van vrije dagen, delen van vakanties, avonden en weekends, maar ook in verschillende vormen van afwezig zijn, verstrooidheid. Rosita, maatje, ook dit heb je weer van me gepikt, je bent een kei. Dank je!

Joop van Duren

Ubachsberg, juni 2013 


\section{inhoudsopgave}

Voorwoord

Overzicht bijlagen

Lijst van tabellen

Lijst van afbeeldingen

Lijst van afkortingen

Samenvatting

1 Het waarom van dit onderzoek en de onderzoeksopzet

1 Wat kunt u in dit hoofdstuk verwachten?

1.2 Waarom dit onderzoek?

1.3 Onderzoeksopzet

1.4 Onderzoeksmethode

$2 \quad$ Wat is pips en tot welke resultaten leidt pips?

Inleiding op pips

2.2 Pips resultaten

2.3 Pips resultaten vergeleken met 'low bid'

3 De werking van PiPs verklaard

3.1 Information Management Theory \& Kashiwagi Solution Model; een introductie

3.2 Bieden Iмт en кsм voldoende verklaringskracht?

3.3 Inleiding in New Institutional Economics (NIE)

3.4 New Institutional Economics Theorieën

3.5 Opportunisme, onzekerheid, safeguarding, begrensde rationaliteit en vertrouwen

3.6 De link tussen pips en NIE mechanismen 
pips elementen en safeguards

Deelconclusies over de werking van pips

4 Pips en het in Nederland geldende juridische kader

4.1 Inleiding op de juridische inpasbaarheid van pips binnen het in Nederland geldende juridische kader

4.2 Het in Nederland geldende juridische kader

4.3 Verbinding pips elementen met het juridisch kader

4.4 pips elementen in de niet openbare aanbestedingsprocedure

4.5 Deelconclusies pips versus juridisch kader

4.6 Reflectie op juridische bevindingen

5 De toepassing van Pips bij praktijkcases

5.1 De onderzoeksopzet van de case studies

5.1.1 De vier criteria van Yin

5.1.2 Systematiek van case beschrijvingen

5.2 De Onderhoudsprojecten UMC St Radboud

5.3 Nieuwbouw parkeergarage UMC St Radboud

5.4 Nieuwbouw Fase III UMC St Radboud

5.5 Bergbezinkbassin gemeente 's-Hertogenbosch

5.6 Cross Case Analyse

5.7 Deelconclusies praktijkcases

6 Validatie van theoretische bevindingen door kwantitatief onderzoek

6.1 Waarom kwantitatief onderzoek?

6.2 Opbouw en verantwoording

6.3 Onderzoeksresultaten, verwerking en analyse

6.4 Deelconclusies Kwantitatief Onderzoek

\section{Conclusies en aanbevelingen}

7.1 Overzicht van conclusies

7.2 Aanbevelingen
$8 \quad$ Reflecties en bijdragen

8.1 Methodologische reflectie

8.2 Terugkoppeling onderzoeksresultaten naar vooronderstellingen

8.3 Reflecties

8.4 Bijdragen

Literatuurregister

Bijlagen

Over de auteur

Reflectie op de rol van Kashiwagi bij pips in NL
313 


\section{overzicht bijlagen}

Bijlage I Manco's van traditioneel aanbesteden

Bijlage II Pips in detail

Bijlage III Vragenlijst Opdrachtgevers verkennend onderzoek USA

Bijlage IV Innovatieve pips elementen

Bijlage $V$ NIE

Bijlage VI Pips versus NIE

Bijlage VII pips safeguards versus onzekerheid en opportunisme

Bijlage VIII Aanbestedingsprocedures

Bijlage IX Interviewronde Juristen

Bijlage X Overzicht Bvp projecten door J. van Duren begeleid

Bijlage XI Online enquête 


\section{lijst van tabellen}

Tabel 2.1 Vergelijkend overzicht "Kashiwagi, van Bentum"

Tabel 2.2 Overzicht traditionele aanpak, Revaluing Construction en pips

Tabel 3.1 Invloed van safeguard functioneel specificeren op NIE mechanismen

Tabel 3.2 Invloed van safeguard informeren over max budget op NIE mechanismen

Tabel 3.3 Invloed safeguard PPI op NIE mechanismen

Tabel 3.4 Invloed safeguard kwaliteit sleutelfunct. op NIE mechanismen

Tabel 3.5 Invloed van safeguard RAP/RAVA op NIE mechanismen

Tabel 3.6 Invloed van safeguard prijs/kwaliteit op NIE mechanismen

Tabel 3.7 Invloed van safeguard pre-award fase op NIE mechanismen

Tabel 3.8 Invloed van safeguard PCR op NIE mechanismen

Tabel 3.9 pips elementen gesorteerd naar soorten safeguards volgens Williamson

Tabel 4.1 Toepassingsmogelijkheden Pips elementen binnen вAо

Tabel 5.1 Safeguards en hun effecten bij uMc St Radboud onderhoudsprojecten 
Tabel 5.2 Invloed safeguards op NIE mechanismen bij UMC St Radboud onderhoudsprojecten

Tabel 5.3 Safeguards en hun effecten bij UMC St Radboud parkeergarage

Tabel 5.4 Invloed safeguards op NIE mechanismen bij UMC St Radboud parkeergarage

Tabel 5.5 Safeguards en hun effecten op NIE mechanismen bij UMC St Radboud Fase III

Tabel 5.6 Safeguards en hun effecten bij's-Hertogenbosch bergbezinkbassin

Tabel 5.7 Invloed safeguards op NIE mechanismen bij 's-Hertogenbosch bergbezinkbassin

Tabel 5.8 Cross case analyse pips safeguards

Tabel 5.9 Cross case analyse leerpunten en conclusies

Tabel 6.1 Verdeling respondenten naar sector

Tabel 6.2 Verdeling respondenten naar ervaringscategorie

Tabel 6.3 Verdeling respondenten naar publieke en private domein

Tabel 6.4 Verdeling respondenten naar achtergrond

Tabel 6.5 Procentuele verdeling mate van ervaring met pips elementen PipsoG en Pipson

Tabel 6.6 Tendenties Pipsog inclusief Cronbach's a

Tabel 6.7 Tendenties Pipson inclusief Cronbach's a

Tabel 6.8 Verschillen in antwoorden tussen minder/meer ervaring pipsoG
Tabel 6.9 Verschillen in antwoorden tussen minder/meer ervaring Pipson

Tabel 6.10 Gemiddelde waarden van effecten pips safeguards volgens respondenten Pipsog en PiPSON

Tabel V.1 Zes types transacties volgens Williamson

Tabel V.2 Overzicht transactietypen en meest gewenste contractvormen (Williamson)

Tabel V.3 Overzicht raakvlakken en overlappingen TCE theorieën.

Tabel VI.1 Invloed pips elementen op NIE mechanismen

Tabel VI.2 Invloed van pips elementen op directe projectkosten

Tabel VII.1 Confrontaties pips safeguards met onzekerheid opdrachtgevers

Tabel VII.2 Confrontaties pips safeguards met opportunisme opdrachtnemers

Tabel VII.3 Confrontaties Pips safeguards met onzekerheid opdrachtnemers

Tabel VII.4 Confrontaties pips safeguards met opportunisme opdrachtgevers

Tabel X.1 Overzicht BVP projecten door J. van Duren begeleid 


\title{
lijst van afbeeldingen
}

\author{
Afbeelding 1.1 Structuur Onderzoek \\ Afbeelding 3.1 Principal/Agent enMonitoring/Bonding costs \\ Afbeelding 3.2 Schematische weergave theoretisch model \\ Afbeelding 4.1 Schematische weergave Pips aanbesteding var. I \\ Afbeelding 4.2 Schematische weergave Pips aanebsteding var. II \\ Afbeelding 5.1 Illustratie van PPI vragenlijst \\ Afbeelding 6.1 Schematische weergave van theoretisch model \\ Afbeelding 6.2 Geconcretiseerde onderzoeksopzet \\ Afbeelding 6.3 Boxplots Pipsog onzekerheid \\ Afbeelding 6.4 Boxplots Pipsog opportunisme \\ Afbeelding 6.5 Boxplots Pipson onzekerheid \\ Afbeelding 6.6 Boxplots Pipson opportunisme
}


Afbeelding II.1 Beoordelingsstructuur

Afbeelding II.2 Past Performance Criteria

Afbeelding II.3 Voorbeeld DIM score

\section{lijst van}

\section{afkortingen}

$B A O$

$B V P$

DBM

$E I B$

Funcspec

Harddat

IMT

KSM

NIE

OG

ON

$P C R$

PIPS

PiPSOG

PiPSON

PPI

Pr/kwal

PSiBouw

Qsleutelf

RAP

RAVA

Risktrans

TCO

Besluit Aanbestedingsregels Overheidsopdrachten Best Value Procurement

Design, Build, Maintain

Economisch Instituut voor de Bouwnijverheid

Facility Management

Functioneel Specificeren

Harde Performance data

Information Management Theory

Kashiwagi Solution Model

Life Cycle Costs

New Institutional Economics

Opdrachtgever

Opdrachtnemer

Post Construction Rating

Performance information Procurement System

Kwantitatief onderzoek onder Opdrachtgevers

Kwantitatief onderzoek onder Opdrachtnemers

Past Performance Information

Prijs-Kwaliteit verhouding

Proces \& Systeem Innovatie in de Bouw

Kwaliteit Sleutelfunctionarissen

Risk Assessment Plan

Risk Assessment Value Added

Risk Transfer

Total Costs of Ownership 


\section{samenvatting}

De waarde van pips voor de Nederlandse Bouwsector verklaard. In het post-bouwfraude tijdperk zijn er vele initiatieven ontstaan om de samenwerking tussen opdrachtgevers en opdrachtnemers te bevorderen, faalkosten terug te dringen en de sector te professionaliseren. Parallel aan de Regieraad Bouw en PSiBouw programma's deed Perfomance information Procurement System (hierna afgekort met Pips) in 2003 voorzichtig haar intrede in Nederland. Vanuit Amerika werd melding gemaakt van opmerkelijk positieve resultaten. Tijdens de eerste verkenningen en daarop gebaseerde toepassingen bleken projecten die PiPS wise aanbesteed werden inderdaad tot goede resultaten (vooral: eindresultaat binnen planning en budget en naar tevredenheid opdrachtgever) te leiden. De bestaande verklaringen voor het pips succes op basis van de informationfactor (in het kort: indien meer relevante informatie kwalitatief beter en sneller wordt verwerkt en benut, leidt dat tot betere beslissingen en daarmee een groter voorspellend vermogen van een aanbesteding) waren niet bevredigend om de pips effecten in de breedte te kunnen begrijpen. De basis van het nu voorliggend onderzoek werd gevormd door de uitdaging de werking van pips te doorgronden vanuit erkende theorieën.

De centrale vraag in dit onderzoek luidt dan ook als volgt:

"Hoe kan de werking van PiPs worden verklaard? Of anders gezegd: welke mechanismen liggen ten grondslag aan de successen van PiPs?"

\section{Een korte introductie van pips}

Een pips aanbesteding bestaat uit een aantal werkzame elementen. Deze elementen worden in dit onderzoek geïnterpreteerd als zogeheten safeguards. Een safeguard is een maatregel die gericht is op het reduceren 
van onzekerheid en/of het ontmoedigen van de neiging tot het vertonen van opportunistisch gedrag. Deze mechanismen vormen een belangrijk onderdeel van New Institutional Economics (NIE). Deze benadering vormt het uitgangspunt bij het zoeken naar het antwoord op de centrale vraag zoals voor deze alinea weergegeven.

In dit onderzoek staan de volgende safeguards centraal, gerangschikt naar de contact-, contract- en controlfase. Waar "pips filter" wordt vermeld gaat het om een werkzaam element zoals door Kashiwagi/pips gehanteerd:

\section{Contactfase}

- Oplossingsvrij specificeren

Maximaal beschikbaar budget vooraf mededelen

- Past performance informatie mee laten wegen; Pips filter 1

\section{Contractfase:}

- Risico's laten duiden en aan laten geven hoe men die denkt te managen; optimalisaties laten inbrengen; pips filter 2

- Sleutelfunctionarissen interviewen en de resultaten daarvan mee laten wegen; pips filter 3

- Kwaliteit/prijs verhouding mee laten wegen; Pips filter 4

\section{Controlfase:}

- Risico's overdragen; pips filter 5

- Performance management o.b.v. harde data; pips filter 6

- Performance rating na oplevering; pips filter 7

\section{Introductie van het theoretisch model}

Toepassing van deze safeguards reduceert onzekerheid, verkleint de ruimte voor en neiging tot het vertonen van opportunistisch gedrag na gunning en reduceert de consequenties van begrensde rationaliteit. Omdat deze laatste factor, begrensde rationaliteit, zich vertaalt in het nemen van beslissingen (op basis van ervaring of op basis van een deel van de beschikbare informatie en/of op basis van gebrekkige interpretatie/benutting van beschikbare informatie) in plaats van de relevante beschikbare informatie snel en goed te verwerken en 'voor zich te laten spreken', manifesteert begrensde rationaliteit zich in meer onzekerheid.
Geringere onzekerheid en ontmoedigd opportunistisch gedrag dragen bij aan projectsucces. Onzekerheid en opportunisme kunnen zowel bij opdrachtgever als opdrachtnemer een rol spelen tijdens de aanbesteding en tijdens de samenwerking. Behalve aan het reduceren van onzekerheid en het ontmoedigen van opportunistisch gedrag leidt toepassing van pips elementen ook tot andere effecten zoals een efficiënter proces, lagere transactiekosten, professionalisering van de sector en grotere tevredenheid over het eindresultaat. Bovendien zijn er de invloeden van factoren die buiten de pips aanpak liggen (denk aan weer, markt, ondergrond etc). Deze rechtstreekse effecten worden in onderstaand model weergegeven door middel van de pijl die rechtstreeks loopt van de "overige factoren" naar "projectsucces". In schema:

\section{Overige}

factoren

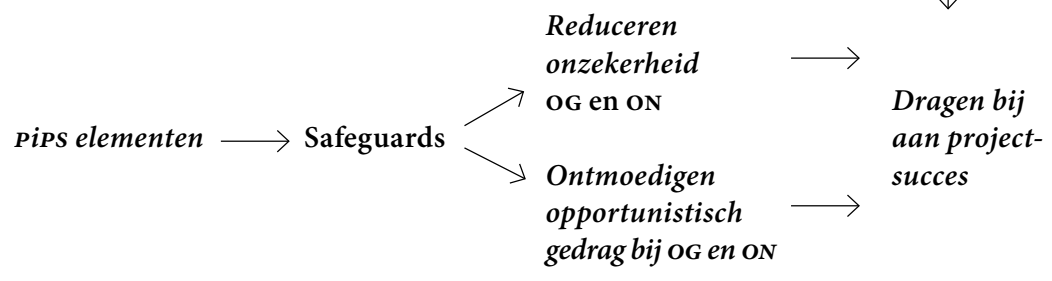

pips en het in Nederland geldende juridische kader

Een belangrijke voorwaarde voor de implementatie van PiPs wise-aanbestedingen is gelegen in het antwoord op de vraag of en vooral hoe aanbestedende diensten die gehouden zijn aan het wettelijke kader (In Nederland gevormd door het BAO: Besluit Aanbestedingsregels Overheidsopdrachten) de verschillende pips elementen toe kunnen passen volgens en binnen dat kader. In de praktijk zien we in toenemende mate 
dat aanbestedende diensten elementen van de pips methodiek toepassen. De vraag of alle pips elementen toepasbaar zijn, is daarmee nog niet beantwoord. Vandaar dat in dit onderzoek ook nagegaan wordt over welke elementen nog discussie gevoerd wordt en over welke elementen helderheid bestaat met betrekking tot de vraag of toepassing van dit element door een aanbestedende dienst wel of geen fricties met het juridisch kader kent.

Het juridisch kader blijkt ruime mogelijkheden te bieden om invulling te geven aan Best Value Procurement (pips staat ook onder deze aanduiding bekend). De pips elementen uit de contact- en contractfase kunnen deels zonder meer toegepast worden, deels onder voorwaarden. De controlfase valt buiten het bestek van het juridisch kader ten aanzien van aanbesteden. Toch is er een element uit de controlfase dat zodanige impact heeft op toekomstige aanbestedingen, dat dit element wel onder het bereik van het juridisch kader valt: PCR. Toepassing van dit element wordt sterk ontraden. Daarnaast is het hanteren van interviews met sleutelfunctionarissen een item waarover de meningen verdeeld zijn. Dit element kan niet zomaar 'automatisch' in een procedure opgenomen kan worden. Dit geldt evenzo voor de prijs/kwaliteit verhouding en het gebruiken van PPI in de selectiefase. De prijs/kwaliteit verhouding kan alleen toegepast worden wanneer EMVI als gunningscriterium wordt gehanteerd. PPI kan toegepast worden in de selectiefase in de vorm zoals in het kader van dit onderzoek ontwikkeld. Voor alle toepassingen geldt dat de aanbestedingsbeginselen steeds gerespecteerd dienen te worden.

\section{pips in de praktijk}

Toepassing van pips elementen bij praktijkcases heeft de theoretische vooronderstellingen zoals hiervoor schematisch weergegeven voor een belangrijk deel bevestigd. Waar deze mechanismen niet uit de verf kwamen, kan dit aan de hand van situationele omstandigheden worden beredeneerd en verklaard.

Ook een kwantitatief onderzoek maakt deel uit van dit promotieonderzoek. Met dit kwantitatieve onderzoek werd getoetst of 'de praktijk' verwacht dat toepassing van pips elementen zal leiden tot de effecten zoals verwacht op basis van het ontwikkelde model. Dat model geeft aan dat toepassing van pips elementen onzekerheid reduceert en de neiging tot het vertonen van opportunistisch gedrag ontmoedigt. Respondenten zijn het daar grotendeels doch niet geheel mee eens. Dit kwanitatief onderzoek heeft geleid tot onderstaande inzichten.

\section{De belangrijkste conclusies van dit onderzoek}

Toepassing van pips safeguards reduceert onzekerheid voor de opdrachtgever. De pips aanpak zorgt ervoor dat er meer en ook meer relevante informatie beschikbaar is op basis waarvan keuzes gemaakt worden. Door informatie ten aanzien van het maximaal aan te wenden budget op voorhand met marktpartijen te delen (en er de consequentie van 'terzijde legging' bij overschrijding daarvan aan te verbinden) word het risico van ongeldige inschrijvingen verkleind. Het risico van het kiezen van een incompetente marktpartij is kleiner doordat past performance information meeweegt en ook de mate waarin een marktpartij in staat is risico's te duiden, ze te prioriteren en van adequate remedies te voorzien van invloed is op de uiteindelijke keuze. Onzekerheid ten aanzien van de vraagspecificatie wordt gereduceerd doordat de verantwoordelijkheid voor een 'werkende oplossing' ligt bij de marktpartij die deze oplossing inbrengt en alleen inbreng van partijen met bewezen high performance uiteindelijk toegelaten worden. Onzekerheid ten aanzien van het naleven van het overeengekomene wordt gereduceerd doordat de 'laagste-prijs-klem' wordt gemeden, er tijdens de uitvoering harde performance data beschikbaar is en het 'reputatiemechanisme' haar werk kan doen.

Voor opdrachtnemers wordt onzekerheid gereduceerd omdat ze het project meer naar hun hand kunnen zetten, ze zich kunnen onderscheiden op kwalitatieve criteria en niet alleen op laagste prijs, waardoor het realiseren van een faire marge binnen bereik komt. Ze kunnen dus een aanbesteding winnen op basis van een slimme oplossing, een geschikte projectleider, een van visie getuigend en wel doordacht risk assessment plan. Dat zijn allemaal zaken waar ze zelf invloed op kunnen uitoefenen, daardoor hebben ze meer vertrouwen in de goede afloop van een project.

Het toepassen van pips safeguards reduceert de neiging tot opportunistisch gedrag van opdrachtnemers doordat er sprake is van gunnen op waarde (in plaats van gunnen op laagste prijs bij de traditionele aanpak). Ze kunnen het zich daardoor permitteren om vakmensen, deugdelijke 
materialen etc. in te zetten. Marchanderen daarmee is simpelweg niet nodig in dit concept. Hier staat tegenover dat in situaties waarin de kosten de opbrengsten dreigen te overschrijden (reëel risico bij het

hanteren van de 'laagste-prijs-klem'), het waarschijnlijk is dat de opdrachtnemer zich opportunistisch zal gedragen. Ook het vroeger betrekken van opdrachtnemers en ze ruimte bieden om eigen inbreng te hebben reduceert de neiging tot opportunistisch gedrag doordat er sprake is van een groter commitment met het project en ook naar de opdrachtgever toe. Als derde element in dit kader speelt het 'reputatiemechanisme' een belangrijke rol. Opdrachtnemers weten dat de op dit werk feitelijk gerealiseerde performance goede of minder goede PPI scores op zal leveren die ingezet kunnen worden bij toekomstige aanbestedingen en daarmee van invloed zijn op de kansen op toekomstig werk. Opportunistisch gedrag draagt daar niet aan bij.

Opportunistisch gedrag aan opdrachtgeverszijde wordt in de ogen van opdrachtnemers slechts in beperkte mate ontmoedigd door het toepassen van pips. Een mogelijke verklaring hiervoor is gelegen in het feit dat opdrachtgevers decennia lang de werkwijze gehanteerd hebben 'alles' voor te schrijven en vervolgens te zoeken naar de partij die het gevraagde tegen de laagste prijs kan realiseren. De veronderstelling luidt dat opdrachtnemers sceptisch zijn ten opzichte van een gedragsverandering hieromtrent bij opdrachtgevers ("willen als het erop aan komt toch voor een dubbeltje op de eerste rang zitten”).

pips speelt in op begrensde rationaliteit van actoren doordat alleen informatie 'toegelaten wordt' die relevant, to the point en countable is. Daarmee wordt een overload aan informatie voorkomen en wordt informatie beter hanteerbaar. Dit uit zich in een compact, in omvang gelimiteerd RAP/RAVA, PPI volgens een format (omvang ook gelimiteerd), het toekennen van scores aan alle pips filters en het werken met harde performance data tijdens de uitvoeringsfase. Dit alles draagt bij aan het verhogen van efficiency, het zo min mogelijk maken van keuzes (op basis van 'ervaring' en/of windowdressing informatie) maar het zoveel mogelijk 'laten spreken' van verzamelde en verwerkte informatie. pips beïnvloedt dus niet begrensde rationaliteit an sich, maar wel de consequenties die deze onontkoombare conditie heeft wat zich manifesteert als geringere onzekerheid.

\section{Aanbevelingen}

Onderstaand volgen de belangrijkste aanbevelingen voor de wetenschap voor beleidsmakers, voor onderwijs, en voor toepassing in de praktijk Als eerste aanbeveling voor de wetenschap geldt het doen van vervolgonderzoek naar de mate waarin opdrachtnemers de pips aanpak onderschrijven; de eerste indicaties duiden er op dat opdrachtnemers kansen zien in deze benadering. Voor beleidsmakers is "BVP tenzij..." de belangrijkste boodschap. Voor het onderwijs luidt de belangrijkste aanbeveling de pips inzichten/aanpak in te bouwen in curricula waarbij het make, buy or ally vraagstuk frequent speelt. Opdrachtgevers wordt aanbevolen leveranciers royaal de ruimte te geven waarde toe te voegen bij het indienen van hun (op een functionele specificatie gebaseerde) oplossing. Opdrachtnemers tenslotte doen er goed aan ervoor te zorgen dat hun inschrijvingsteam die competenties aan boord heeft die nodig zijn om met de "andere" vragen die bij een pips aanbesteding worden gesteld om te kunnen gaan.

Data-collectie heeft aldus (ondanks de actieve participatie van de onderzoeker) geobjectiveerd plaatsgevonden. Bij de verwerking van deze data in dit proefschrift heb ik de data zoveel mogelijk voor zich laten spreken. Evaluatieve opmerkingen zijn gebaseerd op interviews met projectleiders, leden kernteam en ook zijn ervaringen van vertegenwoordigers van leveranciers meegenomen, waarvan ook (goedgekeurde) verslagen zijn gemaakt.

De belangrijkste bijdragen aan de wetenschap bestaan er uit dat er nu een stevig theoretisch fundament beschikbaar is dat de werking van pips verklaart, er zicht is op de juridische inpasbaarheid van de verschillende pips elementen en dat verduidelijkt is dat het verlaten van de laagste-prijs-klem voor opdrachtgevers van veel projecten bijdraagt aan projectsucces. 


\section{het waarom van dit onderzoek en de onderzoeksopzet}

1.1 Wat kunt $u$ in dit hoofdstuk verwachten?

Dit hoofdstuk gaat in op de relevantie van dit onderzoek. Doelstelling
is immers dat dit onderzoek een bijdrage levert aan het verbeteren van
de aanbestedingspraktijk en in het verlengde daarvan aan succesvolle
bouw- en infra projecten. In de tweede plaats geeft dit hoofdstuk inzicht
in de structuur van het onderzoek en wordt een aantal vooronderstel-
lingen gepresenteerd die leidend zijn bij de inrichting en vormgeving
van dit onderzoek. 
In het kader van professionalisering en imagoverbetering van de sector zijn er vele initiatieven genomen om de aanbestedingspraktijk te verbeteren. De noodzaak tot verbetering wordt erkend door opdrachtgevers en opdrachtnemers. Initiatieven als PSiBouw (Proces en Systeem innovatie in de Bouw) en Regieraad Bouw getuigen van deze verbeternoodzaak. Ook diverse wetenschappelijke publicaties waaronder Revaluing Construction (Barret, 2007) benadrukken het belang van het verbeteren van samenwerking, het reduceren van faalkosten. In veel publicaties wordt 'anders aanbesteden' genoemd als effectief aangrijpingspunt voor de gewenste verbeteringen. Zo beschrijven Eriksson \& Pesamaa (2007) een toenemende interesse voor samenwerkingsvormen in de bouw als reactie op escalerende conflicten en vijandige verhoudingen tussen opdrachtgevers en opdrachtnemers. Ze refereren daarbij aan diverse auteurs (o.a. Bresnen \& Marshall, 2000; Chan et al, 2003; Graafland \& Nijhof, 2007). Dainty et al (2001) benadrukken het belang van aanbesteden voor de mate van samenwerking en integratie tussen opdrachtgever en opdrachtnemer. Ook Seo \& Hyan (2004) en Ive \& Chang (2007) benoemen een "appropriate procurement system" als sleutelfactor voor projectsucces en tevredenheid van de opdrachtgever, ze betogen dat deze keuze een van de belangrijkste beslissingen vormt die een opdrachtgever moet nemen omdat (volgens hun betoog) deze beslissing van grote invloed is op de relaties tussen participanten. Eerder hebben ook Naoum (1995), Rowlinson (1999) en Love et al (1998) het belang (voor projectsucces) van het kiezen van een inkoopsysteem beschreven. Daarnaast beschrijven Egan (1998) en Chan et al (2003) dat betere samenwerking leidt tot voordelen als hogere kwaliteit, veiliger werkomgevingen, duurzaamheid, beter omgaan met conflicten, aantrekkelijker werkgeverschap, innovaties en reducties van bouwkosten en bouwtijd. Van der Rijt, Hompes en Santema (2009) stellen dat andere manieren van aanbesteden bij kunnen dragen aan de binnen de sector nagestreefde veranderingen; zij voorzien dat methodieken als pips (Performance information Procurement System) toegevoegde waarde zullen leveren in vergelijking met de traditionele low bid aanpak.

Vanuit deze breed gedragen overwegingen die de noodzaak van veranderingen illustreren, is het dan ook niet verwonderlijk dat er vele initiatieven zijn op dit gebied.

pips is zo een initiatief. Vanuit Amerika worden sinds 2003 opmerkelijke resultaten gemeld bij toepassing van pips. De meest in het oog springende zijn:

- Nagenoeg alle projecten zijn binnen planning en budget opgeleverd

- Opdrachtgevers en opdrachtnemers zijn tevreden met samenwerking èn het behaalde resultaat

- Betere samenwerking (vergeleken bij de low bid aanpak)

- Besparing van managementtijd aan opdrachtgeverszijde

Deze resultaten bieden, vergeleken met de Nederlandse praktijk, een aantrekkelijk perspectief (EIB onderzoeken; 2005 tot en met 2007; Bremer, 2004; Bijsterveld, 2005; Graafland en Nijhof, 2007). Hierin lig de belangrijkste drijfveer voor dit onderzoek met als centrale vraag:

"Hoe kan de werking van PiPS worden verklaard? Of anders gezegd: welke mechanismen liggen ten grondslag aan de successen van PiPs"

Een pips aanbesteding bestaat uit een aantal werkzame elementen. Deze elementen worden in dit onderzoek geïnterpreteerd als zogeheten safeguards dat wil zeggen een maatregel die gericht is op het reduceren van onzekerheid en/of het ontmoedigen van de neiging tot het vertonen van opportunistisch gedrag. Deze mechanismen vormen een belangrijk onderdeel van New Institutional Economics (NIE). Deze benadering vormt het uitgangspunt bij het zoeken naar het antwoord op de centrale vraag zoals voor deze alinea weergegeven.

\subsection{Onderzoeksopzet}

Om het antwoord op deze centrale vraag te vinden is de volgende aanpak gehanteerd. Als eerste is stilgestaan bij de pips methodiek en de daarmee behaalde resultaten; zijn ze van dien aard dat de pips methodiek toegevoegde waarde kan bieden aan de Nederlandse bouwsector? Vervolgens wordt antwoord gezocht op de vraag hoe het komt dat de 
pips methodiek tot deze resultaten leidt en wordt stilgestaan bij de vraag welke (op erkende theorieën gebaseerde) mechanismen daarvoor verklaringskracht bieden en hoe de werking van pips in een op erkende theorie gebaseerd model te 'vangen' is? Het antwoord op deze vragen is van belang met het oog op betrouwbaarheid, herhaalbaarheid en generaliseerbaarheid. Ook is de 'adoptie' van methodieken als pips gebaat bij een heldere, sluitende en plausibele verklaring voor de effecten van de methodiek.

Wanneer we weten of pips tot aantrekkelijke resultaten leidt en modelmatig, met behulp van erkende theorieën, verklaard kan worden waardoor dat komt, dringt zich de vraag op hoe pips toegepast kan worden binnen het geldende juridische kader

(helderheid over de manier waarop pips inpasbaar is, zal toepassing van pips bevorderen). Dit is de volgende deelvraag waarop dit onderzoek ingaat.

Nadat de antwoorden op deze theoretische deelvragen bekend zijn, komen de praktijkcases aan bod. Daarbij staat centraal of, en in welke mate, we bij praktische toepassing van pips de mechanismen volgens het theoretisch model zien optreden en of (en in welke mate) gewenste effecten optreden. Volgens Yin (2008) kunnen case studies zowel gebruikt worden om nieuwe theorie te ontwikkelen, te testen en/of om bestaande theorieën aan te scherpen. In dit onderzoek ligt het accent op het tweede doel (testen), maar de praktijkcases hebben zeker ook bijgedragen aan het aanscherpen van het theoretisch model, het inzicht in de pips werkwijze en aanpassingen daarvan. Omdat het aanta praktijkcases dat in het kader van dit onderzoek is uitgevoerd beperkt is en de cases die 'voorbij kwamen' in een vroeg stadium van het onderzoek als kans zijn aangegrepen, wordt extra validatie gezocht in 'het veld'. Projectleiders aan opdrachtgevers- en opdrachtnemerszijde is gevraagd in welke mate zij het (geoperationaliseerde) model onderschrijven. Schematisch ziet het onderzoek er als volgt uit:

\section{Onderzoeksvraag:}

verklaring werking

pips NL bouwsector?

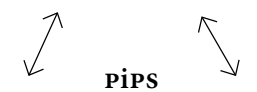

\section{Theoretisch Onderzoek: $\quad \longleftrightarrow \quad$ Praktijk onderzoek:}

- pips en haar resultaten

- Verklaring o.b.v. theorie (model)?

- Toepasbaar binnen juridisch kader? 
PIPS EN HET IN NEDERLAND GELDENDE JURIDISCHE KADER; - theorie -

- inpasbaarheid pips elementen

- ontwikkeling twee varianten voor toepassing pips bij niet openbare procedure

hfdst 5 TOEPASSEN VAN PiPS BIJ PRAKTIJKCASES; - praktijk

- beschrijving uitgevoerde praktijkcases

- Pips effecten en werking NIE mechanismen volgens het theoretisch model ( $\left.\mathrm{H}_{3}\right)$

hfdst

VALIDATIE VAN THEORETISCHE BEVINDINGEN DOOR KWANTITATIEF ONDERZOEK - praktijk

- ontwikkeling en verantwoording van kwantitatief onderzoek

- resultaten en analyse daarvan

\section{hfdst 7 CONCLUSIES EN AANBEVELINGEN}

- wat kan geconcludeerd worden op basis van dit onderzoek?

- tot welke aanbevelingen leidt dit?

$h f d s t \mathbf{8}$

REFLECTIES EN BIJDRAGEN

- terugblik op dit onderzoek

- bijdrage aan wetenschap

Afbeelding 1.1; Structuur Onderzoek

${ }^{1}$ Ook in 2011 en 2012 zijn door de auteur van dit proefschrift pips aanbestedingen begeleid in opdrach van een woningcorporatie, een zorgorganisatie en een Europees instituut. Deze aanbestedingen zijn echter niet als praktijkcase in het kader van dit onderzoek geoormerkt ( zie ook Bijlage $\mathrm{x}$ ). worden welke van deze vooronderstellingen onderschreven worden, en welke vooronderstellingen verworpen danwel bijgesteld dienen te worden:

$n r 1$ PiPS IS WAARDEVOL VOOR DE NEDERLANDSE BOUWSECTOR.

Deze vooronderstelling is enerzijds gebaseerd op het gangbare beeld van de huidige aanbestedingspraktijk en anderzijds gebaseerd op het pips gedachtengoed en de met pips behaalde resulaten.

$n r 2$ NIE KAN DE WERKING VAN PIPS OVERTUIGEND VERKLAREN.

Deze vooronderstelling is gebaseerd op de aanname dat pips de (economische) belangen van opdrachtgever en opdrachtnemer erkent en daarmee constructiever gedrag triggert.

$n$ r 3 HET JURIDISCH KADER BIEDT VOLDOENDE RUIMTE OM PIPS TOE TE KUNNEN PASSEN.

Deze vooronderstelling is gebaseerd op het feit dat (ook publieke) opdrachtgevers pips inmiddels bij een uiteenlopend scala van projecten toepassen.

$n r 4$ PRAKTIJKCASES LATEN RESULTATEN ZIEN DIE OP BASIS VAN HET THEORETISCH MODEL TE VERWACHTEN ZIJN.

Deze vooronderstelling is gebaseerd op het uitgangspunt dat het model de resultante is van erkende theorieën en logische redeneringen.

$n r 5$ HET KWANTITATIEF ONDERZOEK LAAT ZIEN DAT 'DE PRAKTIJK' DE WERKING VAN HET THEORETISCH MODEL ONDERSCHRIJFT.

Deze vooronderstelling is gebaseerd op Best Value Procurement $^{2}$ (BVP) visie ten aanzien van het organiseren van succesvolle samenwerkingen: doe een appèl op vakmanschap, erken wederzijdse belangen en zoek naar de beste aanbieding in plaats van naar de goedkoopste.
${ }^{2}$ BVP wordt als algemene aanduiding gebruikt voor inkoopbenaderingen die gebaseerd zijn op gunnen op waarde; pips is een specifieke methode binnen dit veld. 


\section{Onderzoeksmethode}

Bij de theoretische hoofdstukken vormt literatuuronderzoek naast het interviewen van in aanbestedingsrecht gespecialiseerde juristen de belangrijkste onderzoeksmethode.

Literatuuronderzoek heeft geleid tot de basis waarop theorievorming heeft plaatsgevonden. Dit literatuuronderzoek heeft zich onder andere toegespitst op 'traditioneel aanbesteden', op pips, op New Institutional Economics en op juridische items. Journals als:

- Construction Management \& Economics

- Facilities Management

- Building Research and Information

- Public Procurement

- Academy of Management Journal

- Construction Procurement

- Construction Engineering and Management

- Strategic Management Journal

zijn daarbij waardevolle bronnen gebleken. Vakbladen als Building Business en CoBouw zijn gebruikt om naast de wetenschappelijke discussies ook het 'reilen en zeilen' in de bouwpraktijk beter in beeld te krijgen. Honderden wetenschappelijk artikelen zijn geselecteerd met behulp van relevante zoekwoorden (onder andere: PiPS, BVP, cooperation, transaction costs, principal agency theory, ownership, property rights, safeguards, procurement systems, innovative tendering, information management theory, construction management). Na lezing van de abstracts is een nadere selectie gemaakt van tientallen papers die bestudeerd zijn. Van al deze papers is puntsgewijze samenvatting gemaakt. Aan het einde van elke samenvatting is de betekenis van de inhoud van het betreffende artikel voor dit onderzoek beschreven. Op die wijze is onderzoeksmateriaal verzameld, gesorteerd, bestudeerd, geanalyseerd en is de basis gelegd voor de theoretische hoofdstukken. Uiteraard is het onderzoeks-materiaal daarna door middel van logische redeneringen en verdere toepassing verwerkt zoals in de verschillende theoretische hoofdstukken van dit onderzoek is te lezen.

Voor wat betreft het juridische gedeelte zijn 'Bouwrecht', het Besluit
Aanbestedingsregels voor Overheidsopdrachten (BAO), de 'Leidraad aanbesteden Bouwopdrachten 2009', 'Journal of Law \& Economics' en 'International Construction Law Review' de belangrijkste bronnen voor literatuuronderzoek geweest. Daarnaast heeft de interviewronde plaatsgevonden met 12 juristen op het gebied van aanbestedingsrecht. Daarbij is enerzijds gekozen voor een mix van public en private en anderzijds voor een mix van wetenschappers en praktijkbeoefenaars. Deze keuze is gemaakt om een brede inventarisatie van opinies en interpretaties te bereiken.

Bij de praktische hoofdstukken maak ik een splisting tussen het hoofdstuk over de praktijkcases en het kwantitatief onderzoek.

Voor praktijkcases is gekozen om meer zicht te krijgen op de vraag hoe toepassing van Pips in de praktijk uitpakt; doen de mechanismen wat volgens het theoretisch model verwacht wordt? Bij de praktijkcases geldt dat bij de onderhoudsprojecten en de parkeergarage een studente is ingezet die de processen heeft gemonitord en heeft gedocumenteerd (notulen, aanbiedingsstukken, procesverloop, logboek, scorematrici). Op die wijze is alle data systematisch verzameld en beschikbaar.

Bij de aanbesteding van Fase III (UMC St Radboud) en het Bergbezinkbassin (gemeente's-Hertogenbosch) zijn van alle vergaderingen verslagen gemaakt door projectgroepleden. Ook aanbiedingsstukken, beoordelingsformulieren en scorematrici zijn gedocumenteerd en beschikbaar. Het verloop van de praktijkcases is daardoor reconstrueerbaar.

Het kwantitatieve onderzoek is uitgevoerd om aanvullend aan de praktijkcases te onderzoeken in welke mate 'de praktijk' (de werking van) het theoretisch model onderschrijft. Voor de methodologische aanpak van dit kwantitatieve hoofdstuk, verwiis ik naar hoofdstuk zes alwaar een aparte paragraaf 'opbouw en verantwoording' is opgenomen. 


\section{wat is pips en tot}

\section{welke resultaten \\ leidt pips?}

2.1 Inleiding op pips

In dit hoofdstuk staat de vraag centraal wat pips is en tot welke resultaten toepassing van pips leidt. Logischerwijs begint dit hoofdstuk met een beschrijving van pips (in Bijlage II vindt $\mathrm{u}$ een meer gedetailleerde beschrijving). Daarna volgt een uiteenzetting over de effecten die pips volgens haar ontwikkelaar, Dean Kashiwagi, bereikt. Tot slot volgt een analyse van 400 in de Verenigde Staten uitgevoerde toepassingen waarbij ingezoomd wordt op de daarmee bereikte effecten.

De informatie in dit hoofdstuk is verkregen door middel van literatuuronderzoek en voor een belangrijk deel ontleend aan het door Kashiwag geschreven boek Best Value Procurement, tweede uitgave 2004. Daar waar aan dit boek gerefereerd wordt is volstaan met het tussen [haakjes] weergeven van de bladzijde aanduiding. Daar waar andere bronnen zijn gebruikt, wordt dat op de reguliere manier vermeld. Tevens worden hierbij eigen waarnemingen gebruikt, onder andere opgedaan tijdens deelname aan de Best Value Conference in februari 2005 in Phoenix, USA en diverse gesprekken met Dean Kashiwagi in de loop van 2004 
${ }^{3}$ Onder kwaliteit van sleutelfunctionarissen kan naast de benodigde technische kwalificaties ook aandacht

besteed worden aan samenwerkingsvermogen, sociaal communicatieve skills en managerial competenties. Zaken waarvoor doorgaans pas na gunning (bv. bij Project Start Up; PSU) aandacht

bestaat. tot en met 2012. De ervaringen die tijdens de zogeheten type A meetings gedurende de afgelopen vijf jaren zijn uitgewisseld, hebben bijgedragen aan de inzichten in de pips methodiek en de daarmee behaalde resultaten.

\section{Beschrijving van PiPs methodiek op hoofdlijnen}

pips is in wezen een eenvoudig, niet technisch georiënteerd logisch selectie- en contracterings proces [7-1]. pips is een aanbestedings- én projectmanagementtool die tot doel heeft de meest geschikte partij voor een bepaald project te contracteren en hem aan te sporen high performance/best value te realiseren en tegelijkertijd de managementinspanning die de opdrachtgever aan dat project moet besteden terug te dringen (Kashiwagi, 2001, 2004)

Kort geformuleerd komt pips op het volgende neer [7-4]. Daag marktpartijen uit door bij de uitvraag een oplossingsvrij geformuleerde vraagstelling te hanteren (verderop: Funcspec), en geef daarbij aan wat het maximale budget is dat besteed kan worden aan de gevraagde functionaliteiten (verderop: Budginf). Verzamel en gebruik vervolgens informatie over de performance van inschrijvers uit het verleden (verderop: PPI). Richt een proces in om inschrijvers te kunnen ranken, zowel wat betreft hun prestaties op in het verleden uitgevoerde projecten, als voor wat betreft hun vermogen om het huidige project succesvol te kunnen realiseren. Besteed daarbij aandacht aan prijs/kwaliteit verhouding (verderop: $\mathrm{Pr} / \mathrm{kwal}$ ), kwaliteit van sleutelfunctionarissen (verderop: Qsleutelf) ${ }^{3}$, en aan het inzicht in de aan het aan te besteden project verbonden risico's en de manier waarop men denkt die te managen en aan optimalisaties zoals de marktpartij die inbrengt (verderop: RAVA). Draag projectrisico's over aan de aannemer (verderop: Risktrans), zodat deze 'gedwongen' wordt deze risico's ook daadwerkelijk te managen en te minimaliseren. Sta de gecontracteerde aannemer toe de eigen prestaties te managen en te monitoren, gebaseerd op het minimaliseren van risico's. Volg de performance van de gecontracteerde aannemer op kritische punten (verderop: Harddat), en beoordeel de prestaties met het oog op een penalty of bonus bij een volgende aanbesteding (verderop: PCR; post construction rating).

pips beoogt de risico's bij het definiëren van de vraag, het selecteren van de meest geschikte partij en aanbieding, en tijdens de realisatie van het project te beperken [7-3]. Uitgangspunt is dat de opdrachtgever geen risico's dient te dragen die de opdrachtnemer beter kan managen [7-4] pips beoogt inschrijvers te ranken. De best value inschrijver eindigt in de competitie op de eerste plaats. De relatieve afstand tussen de nummers twee, drie enzovoort wordt cijfermatig uitgedrukt. Bij deze ranking wegen zowel prijs, past performance, kwaliteit van sleutelfunctionarissen, het vermogen om risico's te duiden en te managen en de kwaliteit van de aanbieding mee [7-5]. In tegenstelling tot traditionee aanbesteden is de focus dus gericht op de meeste waarde voor het beschikbare budget, tegen de laagste risico's.

Binnen de pips methodiek is een project succesvol als het binnen de planning en binnen het budget opgeleverd wordt conform de kwaliteitsverwachtingen van de opdrachtgever en naar tevredenheid van de opdrachtnemer ${ }^{4}$.

Een pips aanbesteding is opgebouwd uit een aantal stappen ofwel filters.

Bij elk filter wordt informatie gebruikt en omgezet in een score. De pips filters zijn [7-3]:

\section{$n r 1 \quad$ Past performance Information (PPI)}

$n r 2$ Risk assessment plan value added (RAVA)

${ }^{n r} \mathbf{3}$ Interviews

${ }^{n r} 4 \quad$ Selectie kwaliteit/prijs (Q/€)

${ }^{n r} 5$ Pre-award

nr 6 Performance meting en sturing tijdens de uitvoering

$n r 7 \quad$ Post construction rating (PCR)
${ }^{4}$ Deze beschrijving vormt tevens de

basis voor de definitie van projectsucces zoals in hoofdstuk 6 wordt gebruikt. 
${ }^{5}$ Hieruit spreek al dat de methodiek niet persé integraal toegepast hoeft te worden; slechts die elementen die relevant zijn voor een gegeven aan te besteden werk kunnen worden toegepast.

${ }^{6}$ De auteur van dit proefschrift is door Land van Rode ingehuurd om deze aan bestedingsprocessen vorm te geven, te begeleiden en ingediende stukken mede te beoordelen.
De doelstelling van het hanteren van de eerste vier pips filters is, dat wanneer alle marktpartijen scores krijgen toegekend op deze elementen, uiteindelijk de inschrijver die de beste totaalscore heeft met betrekking tot de som van waarde en risico, op de eerste plaats zal eindigen. pips creëert hiermee een omgeving waarin, zoals Kashiwagi het formuleert, high performers zich thuis voelen, en low performers zich oncomfortabel voelen en uiteindelijk zichzelf zullen diskwalificeren. Het separeren van high- en low performers is de essentie van Best Value aanbesteden. Het behalen van hoge scores op de pips onderdelen die de eindscore bepalen (price, past performance, risk management, interviews, projectplan en schedule) én het accepteren van de over te dragen risico's, vormt bovendien een lastiger opgave voor low-performers dan voor high-performers [7-2]). Daardoor zijn high-performers in het voordeel. Dat past bij de aanbestedingsdoelstelling van de opdrachtgever: selecteren van de partij die het onderhavige project met de meeste waarde, binnen budget, tegen het laagste risico kan realiseren. Low-performers moeten dus ofwel hun bedrijfsvoering verbeteren/aanpassen om reële kansen op werk te hebben in een Best Value omgeving, ofwel zich richten op anders aanbestede projecten, aldus Kashiwagi tijdens de Best Value Conference 2005.

In Bijlage II wordt het verloop van een pips aanbesteding per onderdeel/ stap in detail beschreven.

Elementen van de pips methodiek ${ }^{5}$ zijn in Nederland toegepast door Rijkswaterstaat (RWs) bij de zogenoemde spoedaanpak projecten. Ook enkele aannemers (bijvoorbeeld Heijmans en Ballast Nedam) passen (delen van) deze benadering toe bij het contracteren van onderaannemers. Daarnaast zijn er nog enkele initiatieven van gemeentes (zie verderop bijvoorbeeld de casus van 's-Hertogenbosch in hoofdstuk vijf) en zetten woningcorporaties ook de eerste stappen op dit gebied. Woningcorporatie Land van Rode heeft in 2010 een invlechtingsproject Best Value aanbesteed en in 2011 nog drie projecten ${ }^{6}$. Ook zorgorganisaties ontdekken de voordelen van de pips benaderingswijze. Cicero Zorggroep besteedde in het voorjaar van 2011 de renovatie en het gedurende 20 jaar onderhouden van een Zorgcentrum PiPs wise aan. Begin 2012 heeft Cicero Zorggroep ook de selectie van een bouwteampartner voor de nieuwbouw van een zorgcentrum PiPs wise ingevuld. Ook de uitbreiding, verbouwing en renovatie van een derde zorgcen- trum zal door Cicero in 2013 PiPs wise aanbesteed worden 7 . NEVI makkte begin februari 2012 bekend vijf BVP aanbestedingen 'binnen de zorg' te sponsoren.

\subsection{PiPs resultaten}

In veel van zijn publicaties en lezingen (diverse journal papers, zijn best value boek, diverse conference papers) claimt Kashiwagi met de pips methodiek opmerkelijk positieve resultaten te boeken:

- $\quad 98 \%$ van de projecten wordt binnen budget en planning opgeleverd

- Opdrachtgevers ervaren meer value for money en zijn daardoor meer tevreden in vergelijking met de traditionele aanpak

- Opdrachtnemers zijn meer tevreden omdat ze het project meer naar hun hand kunnen zetten, zich op kwalitatief gebied kunnen onderscheiden en de focus op waarde stelt ze in staat een betere marge te realiseren

- $80 \%$ reductie van benodigde managementcapaciteit ${ }^{8}$ aan de zijde van de opdrachtgever

- Men beschikt over harde performance data en kan daardoor meer gericht en krachtiger sturen.

In deze paragraaf worden deze claims nader bekeken. Daartoe worden de claims vergeleken met de uitkomsten van een analyse van 400 aan bestedingen die in de Verenigde Staten zijn uitgevoerd. Dit verkennend onderzoek is onder leiding van de auteur van dit proefschrift uitgevoerd door afstudeerder van Bentum (European Master Facility Management, 2005).

\section{Claim: meer projecten binnen budget en planning}

Kashiwagi geeft aan (Kashiwagi, 2005) dat pips in de UsA bij ca. 400 aanbestedingen is toegepast (inmiddels meer dan 900 maal), en dat $98 \%$ van die aanbestedingen binnen planning en budget en naar klantverwachting is opgeleverd. In 2008 (Bunnik, oktober 2008) verklaart

Kashiwagi desgevraagd, dat ook na het toepassen van pips bij grote en meer complexe projecten, dit percentage onveranderd is gebleven. Nader onderzoek naar deze claim (op basis van de in 2005 voorhanden zijnde
Ook Cicero Zorggroep heeft de auteur van dit proefschrift ingeschakeld om deze trajecten vorm te geven, te begeleiden en mee te beoordelen.

${ }^{8}$ Tijdens de realisatiefase 


\section{informatie) heeft tot de volgende bevindingen geleid:}

Bij het eerder genoemde verkennend onderzoek (van Bentum, 2005) dat betrekking heeft op relatief eenvoudige projecten, is ingezoomd op de vraag hoe opdrachtgevers en opdrachtnemers de toepassing van pips in de praktijk hebben ervaren. Er is gevraagd naar positieve en negatieve ervaringen, naar voorziene en onvoorziene effecten. De basis voor dit onderzoek is gelegd tijdens de 2005 Best Value Conference, Arizona, Phoenix. Daar zijn afspraken gemaakt over het ter beschikking stellen van (door Kashiwagi geselecteerde) data met behulp waarvan antwoorden gezocht konden worden op de hiervoor gememoreerde vragen. Naar 32 opdrachtgevers is een vragenlijst gestuurd waarbij stellingen (zie Bijlage III) zijn voorgelegd en enkele open vragen zijn gesteld. Deze 32 Pips opdrachtgevers ${ }^{9}$ is gevraagd naar hun ervaringen met deze methode. Van 17 opdrachtgevers is een ingevulde vragenlijst ontvangen. Dit is een gering aantal (niet a-select gekozen), de onderzoeksresultaten dienen dan ook met terughoudendheid te worden geïnterpreteerd; ze vormen slechts indicaties. De belangrijkste resultaten:

- Meer dan 90\% van de 400 projecten binnen planning en budget

- 16 van de 17 respondenten geven aan dat ze dankzij toepassing van pips een betere aannemer hebben gecontracteerd (dan de traditionele aanpak zou hebben opgeleverd);

- 15 respondenten geven een rapportcijfer acht of hoger voor de performance van de aannemer;

- Alle respondenten zouden pips weer gebruiken bij een vergelijkbare aanbesteding;

- Tien van de 17 respondenten geven aan dat de opdrachtnemer onvoldoende wist hoe om te gaan met de pips aanpak;

In dit verkennend onderzoek is aan opdrachtnemerszijde sprake van slechts twee respondenten die meermaals ervaring hebben met pips. Deze respondenten zijn tevens betrokken bij de ontwikkeling van pips. De resultaten uit deze vragenlijsten vormen dan ook geen bruikbare informatie in het kader van dit onderzoek.

Inmiddels is pips ook bij grotere en meer complexe aanbestedingen

toegepast. Hierbij gaat het om enkele tientallen projecten. Ten opzichte van de eerste 400 uitgevoerde pips aanbestedingen gaat het bij deze grotere projecten dus om een relatief klein aandeel in het geheel. De grotere en complexere projecten die pips wise zijn aanbesteed (bijvoorbeeld University of Utah Phase II, \$ 48 miljoen; Reconstruction of Hawaiin highway, \$ 5 miljoen; Georgia Institute of Technology, \$ 45 miljoen), laten volgens Kashiwagi (hieraan is geen toetsend onderzoek gewijd) een bestendiging zien van de eerder met eenvoudiger projecten behaalde resultaten. Met andere woorden, ondanks de grotere managerial uitdaging en de grotere risico's lijkt pips in staat ook deze projecten tot een succes te kunnen maken. pips lijkt dus zowel voor kleinere e minder complexe projecten ${ }^{10}$ als voor meer omvattende en uitdagen-

der projecten tot aansprekende resultaten te leiden.

${ }^{10} 88 \%$ van de door van Bentum (afstudeeronderzoek Master Facility Management, 2005) geënquêteerde opdrachtgevers gaf aan ook voor eenvoudige projecten er de voorkeur aan te geven pips wise aan te besteden.

\section{Concluderend:}

PiPs aanbestedingen leiden volgens het verkennend onderzoek voor eenvoudige projecten tot percentages binnen planning en budget die Kashiwagi's claim benaderen. Voor complexe projecten is een dergelijke kwantitatieve uitspraak niet op basis van eigen onderzoek te doen, doch de voor handen zijnde indicaties ${ }^{11}$ tenderen in dezelfde richting.

${ }^{11}$ Gebaseerd op de in Nederland aan-

Claim: opdrachtgever meer value for money, opdrachtnemer meer profit

Kashiwagi geeft aan dat opdrachtgevers én opdrachtnemers meer tevreden zijn over projecten die PiPS wise zijn aangepakt in vergelijking met projecten die traditioneel zijn aangepakt. Nader onderzoek naar deze claim (op basis van de in 2005 voorhanden zijnde informatie) heeft geleid tot onderstaande bevindingen:

$94 \%$ van de respondenten ${ }^{12}$ in het verkennend onderzoek geven aan dat ze een betere aannemer hebben geselecteerd dan wanneer ze gebruik hadden gemaakt van een traditionele aanpak. Onbesproken blijft of dit effect het gevolg is van de andere aanbestedingsmethodiek, of dat er een voor hen nieuwe aannemer is gecontracteerd waarmee deze opdrachtgevers nog geen eerdere ervaring hadden. Uit onderzoek door Performance Bases Studies Research Group (PBSRG) blijkt dat wanneer bestede werken en de uitspraken van Kashiwagi hieromtrent

${ }^{12}$ Enkele voorbeelden van opdrachtgevers die hebben deelgenomen aan de enquête: United Airlines, IBM/Tuscon, Resno Unified School District, University of Hawaii, Honeywell Inc., State of Wyoming, Motorola, Phelps Dodge Mining Company, US Army/Madigan Army Medical Centre, Intel Corporation. 
Amerikaanse overheidsprojecten volgens de pips methodiek aanbesteed worden, nieuwe succesvolle aannemers meedingen, die eerder in de low bid aanpak niet inschreven op soortgelijke projecten. $94 \%$ van de respondenten geeft aan de performance van de gecontracteerde aannemer met een rapportcijfer acht of hoger te waarderen. Een zelfde aantal geeft aan opnieuw deze aannemer te willen contracteren. Deze scores wijzen in de zelfde richting als de claim dat een PiPs wise aanbesteed project tot value for money leidt.

Gezien het geringe aantal opdrachtnemers dat heeft meegewerkt aan het verkennend onderzoek, zijn geen kwantitatief onderbouwde uitspraken te doen over de mate waarin opdrachtnemers tevreden zijn met hun financiële resultaat bij een pips project. De eerste ervaringen in Nederland maken wel duidelijk dat opdrachtnemers het als een duidelijke pré zien dat pips aanbestedingen zo worden georganiseerd dat niet de goedkoopste aanbieding, maar de beste zal winnen. Hieromtrent zijn echter geen cijfers bekend; dit kan enkel als indicatie gezien worden

\section{Concluderend:}

PIPS opdrachtgevers ervaren value for money, zijn tevereden met het projectresultaat en de ondervonden samenwerking op weg naar dat resultaat.

Eerste indicaties wijzen er op dat PiPS opdrachtnemers positief staan tegenover de aanpak, doch harde cijfers over "meer winst" zijn er vooralsnog niet.

\section{Claim: $80 \%$ minder managementinspanning aan de zijde van} de opdrachtgever.

Kashiwagi geeft aan dat bij PiPs wise aangepakte projecten de totale managementinspanning tijdens de realisatiefase aan de zijde van de opdrachtgever met $80 \%$ gereduceerd wordt vergeleken met de traditionele aanpak. Onderstaand wordt ingezoomed op deze claim. Uit het verkennend onderzoek bleek dat twee van de drie respondenten geen, of een geringere besparing heeft gerealiseerd. Daarnaast moet uitgaande van een situatie waarbij opdrachtgevers en opdrachtnemers niet bekend zijn met pips, rekening gehouden worden met extra initiële tijdsinvesteringen (uitleg, training, interpreteren, beoordelen en ver- werken informatie, interviews houden) gedurende het voortraject. Managementbesparingen tijdens de uitvoering kunnen weliswaa gesaldeerd worden met deze extra bestede tijd. Hoe dit saldo uitpakt is erg afhankelijk van omvang en looptijd van het project. $80 \%$ reductie over de hele looptijd lijkt vooralsnog eerder uitzondering dan regel. Wanneer een groot deel van de risico's overgedragen wordt aan de opdrachtnemer, hij zijn eigen performance daadwerkelijk meet en daarover rapporteert en de opdrachtnemer de uitvoering op redelijke afstand volgt, is de verwachting dat een reductie van managementcapaciteit aan opdrachtgeverszijde met enkele tientallen procenten tot de mogelijkheden behoort. Dergelijke besparingen worden ook genoemd bij Design \& Construct projecten en overige geïntegreerde contractvormen. Hieraan dient echter aanvullend onderzoek te worden gewijd.

\section{Concluderend:}

reductie van managementcapaciteit aan opdrachtgeverszijde is bij pips projecten wel aan de orde, maar de mate van reductie verschilt situationeel (saldo van meer inspanning tijdens voorbereiding en 'terugverdienen' tijdens realisatie). Een systematische reductie met $80 \%$ is vooralsnog niet aangetoond.

\section{Claim: bij een pips project beschikt men over harde} performancedata

Tijdens de aanbesteding beschikt de opdrachtgever over sound information. Tijdens de uitvoeringsfase laat Kashiwagi de gecontracteerde aannemers hun eigen performance meten en daarover rapporteren. Hij stuurt bottomline op één cijfer; het weekly risk number. Dat ene cijfer vormt daarmee een geabstraheerde indicator waarin dreigende overschrijdingen van planning en budgetten zijn verdisconteerd en ook dreigende kwaliteitsproblemen zijn in de formule opgenomen (Sullivan et al, 2006).

Door de systematische wijze waarop Past Performance Information (PPI) wordt verzameld, beschikt de aanbestedende partij over informatie met betrekking tot past performance. pips 'dwingt' de aannemer vervolgens om tijdens de uitvoering zijn performance te meten en daarover 
wekelijks te rapporteren, zoals hiervoor is weergegeven. Of dit wekelijks risk number voldoet aan de behoefte aan stuurinformatie die een opdrachtgever heeft is niet onderzocht. Afhankelijk van complexiteit, omvang, context kan dit afdoende zijn of juist te kort schieten.

\section{Concluderend:}

bij een Pips wise aangepakt project is er tijdens de aanbesteding meer feitelijke informatie voorhanden die het nemen van de juiste beslissingen (met het oog op een hoge mate van voorspelbaarheid) makkelijker maakt ${ }^{13}$. Tijdens de uitvoering is het principe van het op compacte wijze laten rapporteren over de eigen performance voor het ene project passend, terwijl het voor andere projecten ontoereikend kan zijn.

${ }^{13}$ Er hoeven ook

minder beslissingen

te worden genomen

doordat meer infor-

matie beschikbaar

is, die 'voor zich'

spreekt.
Onderstaand in tabelvorm een samenvattend overzicht van de verge-

lijking tussen de pips leer zoals Kashiwagi die uitdraagt met de

resultaten van het verkennend onderzoek.
Onderwerp

Relevantie 400 projecten

op tijd, binnen

planning

Reductie Management

capaciteit bij opdracht-

gever

\section{Tevredenheid achteraf \\ bij opdrachtgever}

\section{Claims Kashiwag}

Complexe projecten.

Focus op waarde

$98 \%$

ie tot $80 \%$ in publicaties. Tot 40\% reductie

is genoemd tijdens PBSRG

conference 2005

$98 \%$

\section{Bevindingen verkennend onderzoek}

Veel eenvoudige projecten. Focus op waarde

$93,5 \%$ binnen planning $96,8 \%$ binnen budget

$80 \%$ reductie lijkt uit-

zondering te zijn.

$30-40 \%$ reductie lijkt

realistischer

93,9\% geeft rapportcijfer acht of hoger.

$100 \%$ zou pips weer als methode hanteren

Is één van de claims

Te weinig waarnemingen om gefundeerde uitspraak te kunnen doen pips draagt bij aan

professionalisering
Harde performance data

Wekelijks door zelfmeting Niet onderzocht beschikbaar 
Pips projecten worden in meer dan $90 \%$ van de gevallen binnen planning en budget opgeleverd. Opdrachtgevers zijn tevreden met het resultaat en de samenwerking om tot dat resultaat te geraken. Alle respondenten in het verkennend onderzoek geven aan pips weer te zullen toepassen. Dat veronderstelt dat minstens aan de verwachtingen (m.b.t. value for money) is voldaan. Wanneer dit vergeleken wordt met het EIB onderzoek 2007 en het onderzoek "opdrachtgevers aan het woord" (2005 t/m 2007 van Regieraad Bouw) tekent zich een beeld af dat de pips resultaten een wenkend perspectief vormen voor de sector. Nederlandse percentages over de mate van tevredenheid van aannemers in het EIB onderzoek "Opdrachtgevers aan het woord" 2005 en 2006 komen (exclusief de scores van particuliere opdrachtgevers en kleine bedrijven) tot een gemiddeld rapportcijfer van 6,8 .

De pips resultaten sluiten aan bij de voor de sector gewenste ontwikkelrichting zoals beschreven in het artikel "Revaluing Construction; a holistic model" in Building Research \& Information (Barrett, 2007). Volgens Peter Barrett verruilt de toekomstige bouwsector de laagste prijsoriëntatie voor 'waarde-oriëntatie' (bij pips speelt prijs doorgaans voor $30 \%$ mee, kwaliteit echter voor $70 \%$ !), en speelt ze beter in op de behoeften van de opdrachtgever (pips opdrachtgevers zijn duidelijk meer tevreden dan 'traditionele opdrachtgevers'). De toekomstige bouwcultuur verlaat volgens Barrett de conflictcultuur en gaat op weg naar een cultuur die gekenschetst wordt door betere samenwerking (pips bevordert samenwerking, geeft partijen de ruimte om hun inbreng te hebben en hun verantwoordelijkheden te nemen). In plaats van een versnipperde sector, schetst Barrett dat partijen in de toekomst vroeger samenwerken en elkaar bij het voorbereidings- en wordingsproces meer betrekken (het hanteren van een oplossingsvrij gespecificeerde vraagstelling, een belangrijk element van pips, bevordert de betrokkenheid en gaat versnippering in de sector tegen). Overschrijdingen van budgetten en plannen zijn dan minder aan de orde van de dag (pips levert projecten in meer dan $90 \%$ van de gevallen binnen planning en budget op). De Bouw is een veilige en aantrekkelijke werkomgeving geworden waarbij professionalisering en innovatie hoog in het vaandel staat (pips bevordert innovatie, door het geven van ruimte om recente ervaringen en knowhow in te brengen, kwaliteit van de oplossing levert onderscheidend vermogen op en pips stimuleert aannemers hun beste personeel in te zetten).

De pips aanpak lijkt dus bij te kunnen dragen aan de beoogde veranderingen; immers kwaliteit en 'waarde' wegen bij de pips aanpak duidelijk zwaarder dan prijs. Opdrachtnemers verdiepen zich in de oplossingsvrij gespecificeerde vraag en worden in een vroeger stadium betrokken, kunnen zich onderscheiden door de kwaliteit van hun eigen oplossing (lees: concurrentie spitst zich toe op de beste oplosing in plaats van op de laagste prijs). Door betere samenwerking en sturing met behulp van performance data, het vooraf gerichter nadenken over (en overdragen van) risico's en bijbehorende remedies worden beduidend meer projecten binnen planning en budget opgeleverd. De oriëntatie op waarde (in plaats van op laagste prijs) biedt ruimte om meer aandacht te besteden aan kwaliteit, maar ook aan duurzaamheid en veiligheid. Opdrachtnemers hebben er belang bij kwalitatief goede oplossingen in te dienen en adequaat personeel in te zetten; een pips project wordt niet gewonnen op basis van de laagste prijs, maar met een doordachte uitwerking en het inzetten van goed personeel. Op de volgende pagina afgebeelde tabel brengt de traditionele kenmerken, de gewenste ontwikkeling van die kenmerken en de wijze waarop pips daarbij aansluit in beeld. 


\section{Traditioneel}

Ontwikkeling zoals

beschreven in

"Revaluing Construction"

Focus op laagste prijs

Focus op waarde

pips speurt naar Best

Eigen belangen centraal

Oog voor wederzijdse belangen

Samenwerking

Conflictcultuur

Versnippering

Integratie

Budget overschrijding

Binnen budget opleveren

Vernieuwend

Behoudend
Value tegen laagste risico

pips

Faire marge; dus belangen

$\mathrm{OG}^{14}$ en $\mathrm{ON}^{15}$ worden

'gezien'

Doel congruentie legt

basis voor goede

samenwerking

Aannemer brengt in vroeg

stadium oplossing in;

bevordert tevens

commitment

$>90 \%$ on time

$>90 \%$ on budget

Bevordert innovatie en

professionaliteit
Deze tabel laat zien dat pips goed aansluit bij en inspeelt op de ontwikkelingen die de sector (Opdrachtgevers en Opdrachtnemers) nastreeft. pips kan daardoor een aantrekkelijk alternatief zijn voor de traditionele aanpak.

\section{Concluderend:}

PiPs resultaten vormen op grond van deze eerste verkenning een wenkend perspectief voor de bouwsector. Voor wat betreft eenvoudige projecten is dit kwantitatief aangetoond. Voor complexere projecten is deze kwantitatieve onderbouwing in mindere mate voorhanden, maar wijzen indicaties op basis van USA en NL projecten in dezelfde richting. Nader onderzoek naar de werking van PiPs is dan ook gerechtvaardigd.

$\mathrm{Nu}$ we op hoofdlijnen bekend is wat pips is en er indicaties zijn dat pips tot aantrekkelijker resultaten leidt dan de traditionele benadering, dringt zich de vraag op hoe de werking van pips verklaard kan worden. Daarop wordt in het volgende hoofdstuk verder ingezoomd.

Tabel 2.2; Overzicht traditionele aanpak, "Revaluing Construction" en PiPS 


\title{
de werking van pips verklaard
}

3.o Inleiding

\begin{abstract}
De centrale vraag in dit hoofdstuk is of- en in hoeverre- New Institutional Economics (NIE) de pips resultaten kunnen verklaren. De keuze voor NIE is enerzijds ingegeven door de vooronderstelling dat NIE goede aanknopingspunten bevat voor het vanuit economische invalshoek onderzoeken van 'transacties' en anderzijds door het feit dat NIE bekend staat als een erkende en vitale set van theorieën.

Als eerste wordt kort stilgestaan bij de verklaringen zoals Kashiwag die zelf presenteert ("zijn gedachtengoed"). Daarbij staan twee door hem zelf ontwikkelde 'denkramen' centraal die beiden de information factor hebben. Omdat voorondersteld wordt dat economische mechanismen een rol spelen bij het andere gedrag bij pips projecten, wordt op zoek gegaan naar aanvullende verklaringskracht bij een set vitale economische theorieën: New Institutional Economics.

Door middel van literatuurstudie is informatie verzameld over NIE. De relatie tussen NIE en pips is gelegd door middel van logische redeneringen en deels eveneens gebaseerd op het uitgebreide literatuuronderzoek naar Best Value Procurement. Uiteindelijk mondt dit uit in een theoretisch model dat de werking van pips verklaart met behulp van twee centrale mechanismen: het reduceren van onzekerheid en het ontmoedigen van de neiging tot het vertonen van opportunistisch gedrag na gunning.
\end{abstract}


3.1 Information Management Theory \& Kashiwagi Solution Model; een introductie

Kashiwagi voert de Information Management Theory (Iмт) en Kashiwagi Solution Model (KSM) aan als "theoretische dragers" voor de pips methodiek; deze beide theoretische denkramen vormen samen het 'Kashiwagi gedachtengoed' op basis waarvan hij de werking van pips verklaart. In deze paragraaf wordt bij beide denkramen stilgestaan.

\section{Information Management Theory (IMT):}

Bij IMT staat centraal dat een 'gebeurtenis' maar op één wijze zal verlopen. Die wijze wordt bepaald door een aantal "initiële condities en wetten". Hoe meer informatie je verzamelt en gebruikt, hoe beter je dus in staat bent het verloop van de gebeurtenis te voorspellen. Dit sluit goed aan bij de theorie rondom the information gap van Galbraith (1973) die het verschil tussen benodigde en beschikbare informatie ziet als belangrijke bron van onzekerheid. Hoe beter je op grond van valide, actuele, juiste informatie kunt voorspellen, hoe lager het risico is

Vertaald naar het aanbesteden op de pips manier, gebruikt Kashiwagi IMT op een aantal punten (Kashiwagi, 2002).

In de eerste plaats bij het gebruik van PPI. Het hebben en gebruiken van informatie over prestatieniveaus uit het verleden, helpt om beter te kunnen voorspellen wat het toekomstig te verwachten prestatieniveau zal kunnen zijn. Als uit deze PPI blijkt dat een bepaalde aannemer in het verleden telkens tijdig en pro actief wist in te spelen op risico's en daardoor projecten tijdig, binnen budget en naar tevredenheid wist af te ronden, is dat bruikbare informatie die het risico van een verkeerde keuze verkleint. Daarnaast ziet Kashiwagi een duidelijk verband tussen het vermogen van een projectleider om relevante informatie snel te kunnen verwerken en adequaat te kunnen gebruiken aan de ene kant en het kunnen opleveren van succesvolle projecten aan de andere kant. Deze verschillen zijn tevens eenvoudig te meten (in termen van ranken) en goed te gebruiken om tot een goede beslissing (voor het selecteren van een aannemer) te komen. Vanuit de IMT theorie beredeneert Kashiwagi verder dat opdrachtgevers niet veel beslissingen zelf moeten nemen, maar vooral de aannemers aan het woord moeten laten (welke risico's zie je, hoe ga je ze managen etc.) en goed moeten letten op informatie die onderscheidend vermogen bevat ten aanzien van prijs, aanpak, risicomanagement, optimalisaties etc.

\section{Waar is IMT op gebaseerd?}

Kashiwagi ontleent aan Hawking's "no Boundary Theory" (1988; tijd en ruimte zijn oneindig) de stelling dat wetmatigheden niet gemaakt maar ontdekt worden. Dit impliceert vervolgens weer dat het aantal wetten in het verleden, heden en toekomst onveranderd zal blijven. Een door Kashiwagi veelvuldig gebruikt voorbeeld:

Als je een pen 1,5 meter boven de grond vasthoudt, en hem vervolgens loslaat zal die naar beneden vallen. Immers, de pen bevat een zekere hoeveelheid potentiële energie, die door de gravitatiekracht omgezet zal worden in neerwaarts gerichte kinetische energie.

Hoe meer relevante informatie je over een gebeurtenis tot je beschikking hebt, en hoe meer van die beschikbare informatie je ook daadwerkelijk aanwendt, hoe groter de kans dat je het verloop van de gebeurtenis correct zult kunnen voorspellen (Galbraith, 1973). Beschik je in mindere mate over het vermogen om relevante informatie te selecteren en te interpreteren, moet je vaker beslissingen nemen, met het risico dat het de verkeerde beslissing is. Dit is in de kern het gedachtegoed achter IMT.

Kashiwagi geeft het zelf als volgt weer [2-2]

"IMT can be defined as: a deductive, logical explanation of an event. It includes the use of relative and related data, to create information that predicts the future outcome of an event."

In zijn boek refereert Kashiwagi verder aan de Information Theory van Claude Shannon (1948). In die theorie staat de transmissiesnelheid van informatie centraal. Kashiwagi linkt de effectieve transmissie-snelheid uit deze theorie met de informatieverwerkingssnelheid van information workers. Kashiwagi zelf publiceerde in 1991 voor de eerste maal over IMT $[2-2]$.

"In addition (...) the author suggests that, when an individual is 
constrained by a slow processing speed, he or she is unable to see readily available information, and is forced to use his or her database of past experience, or incomplete information, to form expectations of future outcomes. The use of an individual's personal experience to draw conclusions is the application of the person's subjective bias, or more commonly known as decision-making. IMT identifies bias as the major obstacle to perfectly understanding reality. [2.1]"

Kashiwagi koppelt deze (hierboven cursief weergegeven) definitie aan twee methodes van 'problem sloving'; de deductieve en de inductieve methode (Davies 1992). De inductieve methode volgt een aantal sequentiële stappen:

- formuleer een hypothese

- bepaal een experiment om de hypothese te toetsen

voer het experiment uit

- onderzoek of de hypothese door het experiment wordt bekrachtigd of ontkrachtigd

- bepaal in welke mate de uitkomsten herhaalbaar zijn.

De inductieve methode leidt tot conclusies die een zekere waarschijnlijkheid bevatten (bijvoorbeeld met een $\alpha$ van o,05 betrouwbaar zijn). De deductieve methode gaat uit van herdefiniëren en herordenen van bestaande informatie om daarmee de verwachte uitkomst te voorspellen. Deductieve benaderingen bestaan vaak uit redeneringen gebaseerd op reeds voor handen zijnde informatie. Deze redeneringen worden zodanig opgebouwd dat de conclusies die de resultante vormen van die redeneringen onvermijdelijk waar moeten zijn. Het verschil met de inductieve methode $[2-2]$ :

- deductie gebruikt geen nieuwe informatie of -theorie

- er vindt geen experiment plaats

- het is sneller, simpeler en goedkoper

- het vereist minder specialistische informatie

- deductie vereenvoudigt complexe situaties.
Kashiwagi maakt vooral gebruik van de deductieve methode om de werking van pips te verklaren aan de hand van het centrale thema the information factor. KSM gaat nader in op deze informatiefactor en wordt hierna besproken.

\section{Kashiwagi Solution Model (KSM):}

In hoofdstuk 3 van zijn boek beschrijft Kashiwagi KsM. Daarbij wordt niet aan bestaande theorie gerefereerd, wel aan bronnen die de karakteristieken van de Japanse samenleving beschrijven [3-8]. Die bronnen worden niet als onderbouwing voor KSM gebruikt, maar als illustratie bij een voorbeeld toepassing (zijn eigen familie betreffend). Tijdens de Conference in Phoenix, februari 2005 bestond de redenering die

Kashiwagi hieromtrent aanreikte ook uit deductieve logica:

- "No event has two outcomes

- All event outcomes can be predicted with "all information"

- More information leads to more accurate prediction

- Not perceiving the information does not change the outcome

- A person without sufficient information, cannot predict the outcome

- This person must take a decision

- With the potential risk that the wrong decision will be made"

Ksm maakt onderscheid tussen 'type A, B en C' mensen (Kashiwagi: "we even barcode people..."). Type A verwerkt informatie snel, type $\mathrm{B}$ gemiddeld en type c langzaam. In zijn uitleg besteedt Kashiwagi nauwelijks aandacht aan Type B, omdat de extremen (A en C) het onderscheid beter verduidelijken tussen beide typen. Kashiwagi noem type A information workers. Ook weet een type a persoon informatie beter op waarde te schatten, te interpreteren en toe te passen. Omdat type a personen over een hoger informatieniveau beschikken, kunnen ze het verloop van een gebeurtenis beter en efficiënter voorspellen.

Kashiwagi typeert type a personen als volgt: ze beschikken over meer informatie, verwerken die efficiënter, passen deze gerichter toe, zijn gericht op win-win situaties, zijn meer leider dan manager en creëren waarde in plaats van waarde te verbruiken. Ksm is zoals uit voorgaande blijkt slechts een 'verlengstuk' van IMT, en vormt geen apart denkkader (Kashiwagi gebruikt in zijn boek ook geen bestaande theorieën om KSM 
op te baseren). KsM kan dan ook niet als zelfstandige theorie worden gekwalificeerd.

Nu de link naar een aanbesteding: wanneer je tijdens een aanbesteding voldoende informatie verzamelt over het vermogen van aanbieders om het onderhavige project tot een succes te maken, hoe groter de kans dat je de meest geschikte partij contracteert voor dat project (IMT). Wanneer je daarbij information workers inzet, verloopt dat proces efficiënter en met minder risico (KSM), zo is de redenering van Kashiwagi ${ }^{16}$. Kashiwagi focust op de beste aanbieder

terwijl doorgaans de focus gericht is op het beste contract, de beste deal. Wannee de lijn van Kashiwagi te rigoreus gevolgd wordt is er een zeker risico weliswaar een geschikte partij te contracteren, maar niet tegen de meest optimale condities. Daarom zetten we bij toepassing van pips in Nederlan in op focus op geschikte partijen tijdens de selectiefase en focus op de beste bieding tijden de gunningsfase. is de uitkomst van aanbestedingsvraagstukken ook afhankelijk van inschrijvingsgedrag van anderen, intersubjectieve beoordelingen van ingeleverde plannen en prijzen, kortom van menselijk gedrag dat behalve door initiële wetten ook bepaald wordt door bijvoorbeeld economische motieven en belangen. Haaks op de IMT benadering staat overigens de Chaos Theorie die door Lorenz in 1963 is ontwikkeld. Deze theorie komt er op neer dat een vleugelslag van een vlinder boven het regenwoud in het Amazone gebied, kan leiden tot een heuse wolkbreuk twee weken later boven New York. Goldberg \& Markóczy (2000) stellen in het verlengde hiervan dat complexiteit de karakteristieke eigenschap vormt van elk geheel dat uit een groot aantal interacterende delen bestaat. Relatief simpele ingrepen kunnen leiden tot interacties tussen al die delen samen en zonder aanwijsbare coördinatie tot onverwachte en volledig nieuwe patronen in het groter geheel.

Deze overwegingen vormen extra argumenten voor het standpunt dat de IMT en Ksм basis te smal en daarmee ontoereikend is als verklaring voor de werking van pips; het samenstel van samenhangende factoren bij een aanbesteding (het project, de inschrijvers, de markt, de beoordelaars, de wijze van beoordelen) is zodanig dynamisch en interfererend dat de 'voorspellende waarde' van IMT en KsM slechts één factor is naast vele anderen die de uitkomst zullen bepalen. Bovendien treden pips effecten pas voor het grootste deel op na gunning en manifesteren die effecten zich in de vorm van betere samenwerking, flexibeler opstelling, meer commitment; kortom een mindset om kwaliteit te willen leveren. Aan deze effecten besteden IMT en KSM minder aandacht. IMT (en KSM) vormt als zodanig geen theorie die qua erkenning en vitaliteit vergelijkbaar is met New Institutional Economics, tevens valt met behulp van Kashiwagi's denkraam maar een deel van de pips effecten te verklaren.

Het feit dat meer PiPS wise aanbestede projecten binnen planning en budget worden opgeleverd is slechts deels te verklaren op grond van het feit dat er meer informatie beschikbaar is die ook sneller en slimmer gebruikt wordt. Na gunning spelen er kennelijk ook andere mechanismen een rol die maken dat de gecontracteerde marktpartij binnen planning en budget blijft. De efficiëntere aanpak is ook slechts deels te verklaren vanuit IMT/KSM. Door te focussen op relevante en objectieve data is tijdwinst te boeken. Maar dat er tijdens de uitvoering minder 
controles en inspecties nodig zijn heeft naar we hier vooronderstellen van doen met meer in elkaars verlengde liggende belangen.

Verderop in dit hoofdstuk wordt aan de hand van New Institutional

Economics gezocht naar bredere en meer gefundeerde verklaringen voor de pips effecten. Naast de "informatiefactor" waaraan Kashiwagi de pips effecten wijdt, is de verwachting dat economisch georiënteerde factoren een rol spelen bij de verklaring van de werking van de methodiek. Het samenspel tussen opdrachtgever en opdrachtnemer wordt immers ingekaderd door een contractuele relatie waar bij wederzijdse economische belangen een rol spelen.

\section{Concluderend:}

IMT en KSM bieden voor een deel van de effecten een verklaring, zij het dat die verklaring niet via een logische en sluitende redeneerlijn tot stand is te brengen. De theoretische basis is bovendien smal, weinig gefundeerd en de redenering is methodolgisch zwak. Voor betere samenwerking en coöperatiever gedrag wordt meer verklaringskracht van economische theorieën verwacht. Daarop wordt in het vervolg van dit onderzoek verder ingegaan.

\subsection{Inleiding in New Institutional Economics (NIE)}

Deze paragraaf beschrijft een set vitale, algemeen erkende economische theorieën waarvan we vooronderstellen dat ze een bruikbare basis vormen om de werking van pips te kunnen verklaren. Deze theorieën staan bekend onder de verzamelnaam New Institutional Economics (NIE) (Alston, 2008). De belangrijkste theorieën in dit kader zijn de transactieosten theorie, de property rights theorie en de principal agent theorie. Deze drie theorieën zijn complementair en leiden tot begrip van gedrag(smotieven) bij het aangaan van, het komen tot en het uitvoering geven aan een economische transactie (Geyskens et al, 2006). In deze paragraaf wordt verder ingezoomd op de mechanismen die deze theorieën beschrijven. Juist het doorgronden van deze mechanismen is van belang bij het kunnen leggen van relaties tussen deze theorieën en pips, hetgeen in de volgende paragraaf aan de orde komt.

Een aanbesteding is te beschouwen als het organiseren van een trans- actie (Ramstad, 1996). Die transactie behelst niet alleen de selectie van een partij en het gunnen, maar loopt door totdat het overeengekomen werk is gerealiseerd. Daarmee legt een aanbesteding de basis voor de samenwerking binnen de 'tijdelijke coaltie' na gunning. Transaction Costs Economics (TCE; belangrijk onderdeel van New Institutiona Economics) handelt over het streven naar de laagste som van productieen transactiekosten (Williamson, 1975). TCE is voor het organiseren van een transactie (aanbesteding) van belang, omdat bepaalde organisatievormen voor bepaalde transacties geschikter zijn dan andere. TCE gaat over het vinden van de meest geschikte organisatievorm, gegeven de eigenschappen van de transactie. Bepaalde organisatievormen kennen voor een gegeven transactie namelijk een hoger kostenniveau (kijkend naar de som van productie- en transactiekosten) dan andere

(Williamson, 1975).

De centrale opgave van TCE is dan ook volgens Williamson (1975) voor een betreffende transactie de meest aangewezen economische bestu-

ringsstructuur te bepalen, rekening houdend met transactie specificiteit, de mate van onzekerheid, de frequentie waarin de transactie voorkom en de duur van de samenwerking op basis van die transactie. Een bouwproject is te zien als een tijdelijke coalitie van en tussen verschillende partijen die door contracten bijeen wordt gehouden. Dit maakt bouwprojecten bijzonder (Chang \& Ive, 2007) ten opzichte van 'reguliere productie'. Opvallend in dit kader is de discontinuiteit vanwege het projectmatige karakter van de branche. Ook is er geen sprake van een vaste productie site. Tot slot speelt er het zogenaamde endogene design; design is onderdeel van het productieproces. Met andere woorden: ook het ontwerpen en engineeren van het project is transactiespecifiek (hoewel er op componentniveau wel sprake is van standaarden die bij uiteenlopende projecten terugkeren).

Bij bouwopgaven is vaak sprake van een zeer hoge mate van transactiespecificiteit (het werk wordt aan dit ene gebouw op deze plek uitgevoerd), onzekerheid (alle betrokkenen weten aan het begin van het project niet hoe ze er aan het einde van het project bij zullen zitten; de opdrachtgever heeft een meer of minder praktisch gebouw dan gedacht, de aannemer meer of minder winst dan gedacht, men heeft prettig samengewerkt of 'het is oorlog geweest', in hoeverre is de orderportefeuille na afloop van dit project gevuld?), een lage frequentie (een 
${ }^{17}$ Opportunistisch gedrag na gunning komt veelvuldig voor bij aanbestede werken die gegund zijn op laagste prijs. De aannemer heeft dan 'diep moeten gaan' om het werk binnen te halen en daarmee continuiteit van zijn bedrijf(svoering) gecreëerd; het realiseren van een 'gezonde' marge op zo een werk gaat in de praktijk noga eens gepaard met vormen van opportunistisch gedrag. tie beschreven door Coase, maar in wetenschappelijke literatuur wordt veel vaker gerefereerd aan Berkely professor Williamson.

Williamson heeft transactiekosten to eenheid van onderzoek gemaakt (Lai, Ng \& Yung, 2008) bouwwerk wordt doorgaans voor minstens 20 - 30 jaren gemaakt) en een lange duur (een bouwproject duurt al gauw enkele maanden tot jaren).

Economische belangen en motieven zijn van invloed op het doen en laten, kortom op het gedrag van opdrachtgever en opdrachtnemer in een contractuele coalitie (Menard et al, 2005). Beperkte ofwel begrensde rationaliteit (Simon, 1976) en opportunisme (Williamson, 1985) zijn in dit kader belangrijke gedragsproposities (Dorée, 1996). Met begrensde rationaliteit bedoelen we hier dat niet alles voorzien kan worden, dat er grenzen zijn aan communicatie- en het bevattingsvermogen (vermogen informatie te interpreteren, te verwerken) van functionarissen hetgeen onzekerheid met zich meebrengt.

Met opportunistisch gedrag ('opportunisme') wordt hier bedoeld dat een partij zijn eigen belangen nastreeft, desnoods ten koste van de belangen van de andere partij (self-interest seeking with guile)

(Williamson, 1975). Na het sluiten van het contract tussen opdrachtgever en aannemer, bevinden beiden zich in een bilaterale monopoliepositie (de 'fundamentele transformatie' heeft zich voltrokken) wat ex post opportunistisch gedrag in beginsel mogelijk maakt (Coase, 1937,

Williamson, 1975, Chang \& Ive, 2007). Als er dan ook nog vanuit het perspectief van één van beiden het beeld ontstaat dat opportunistisch gedrag 'nodig is' om de eigen belangen veilig te stellen (bijvoorbeeld omdat de kosten de opbrengsten dreigen te overschrijden, Kadefors, 2005), groeit de onzekerheid zodanig dat projectsucces daardoor bedreigd wordt. ${ }^{17}$

\section{New Institutional Economics Theorieën}

Zoals hiervoor al kort gememoreerd zijn TCE, principal agent en property rights de belangrijkste componenten van NIE. In deze paragraaf worden deze drie theorieën besproken en wordt de betekenis ervan voor dit onderzoek verklaard.

\section{Transaction Costs Economics: TCE}

Williamson ${ }^{18}$ stelt in zijn artikel "Transaction cost economics; the governance of contractual relations" in the Journal of Law \& Economics in 1979 dat de transactie het centrale object van studie moet zijn in de economie. Deze keuze heeft bijgedragen aan het succes van TCE. Zijn stelling komt erop neer dat de karakteristieken van een transactie bepalend zijn voor de manier waarop de transactie kan worden georganiseerd:

- binnen de hiërarchie van de eigen organisatie waarbij de eigen hiërarchie besturend optreedt en eigen incentive structuren hanteert

- middels een contract met een marktpartij waarbij sprake is van concurrentiestelling waarbij de marktwerking besturend optreedt; de zogeheten invisible hand (Williamson, 1979)

- een hybride vorm waarbij sprake is van een langdurig samenwerkings-

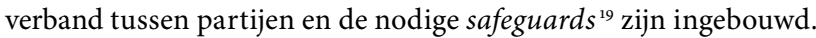

De term 'transactie' wordt door Williamson $(1985$, ) als volgt omschreven: "a transaction occurs when a good or service is transferred across a technologically separable interface". Nooteboom (1992) voegt daaraan toe dat een transactie een gebeurtenis is die deel uitmaakt van een ruilproces. Aan een transactie zijn kosten verbonden zowel ex ante als ex post. Hieronder kan worden verstaan kosten van het zoeken, van evalueren, en kiezen van opties; van planning, vormgeving en onderhandeling van overeenkomsten; van controle op naleving van overeenkomsten en uitvoering van eventuele sancties; van aanpassing van overeenkomsten en het oplossen van conflicten. Ook omvatten dergelijke kosten inefficiënties door misverstanden, verkeerde beslissingen, slechte afstemming, imperfecte naleving van overeenkomsten en risico's van verlies van investeringen (Nooteboom, 1992). Speklé (2001) verwoordt de essentie van TCE als volgt: gegeven opportunisme en begrensde rationaliteit, zullen de eigenschappen van transacties (specificiteit, onzekerheid en frequentie) aanleiding geven tot voorspelbare problemen waarmee contractpartijen om zullen moeten gaan. Graafland en Nijhof (2007) onderschrijven wat eerder werd opgetekend over begrensde rationaliteit en geven aan dat een overload aan informatie averechts werkt. De informatie is niet meer te overzien, niet meer te controleren, de waarde van de informatie is niet meer goed vast te stellen en de inhoudelijke essenties (van de informatie) zijn niet meer helder te duiden. Hiermee illustreren Graafland en Nijhof het TCE principe van begrensde rationaliteit.
${ }^{19}$ Safeguards worden verderop in dit hoofdstuk toegelicht 
${ }^{20}$ Williamson voegde aan transactiekosten zaken als opportunistisch gedrag en shirking (je ergens makkelijk vanaf maken) toe. Volgens sommige neo institutionele economen double count hij daarmee transactiekosten. In dit onderzoek nemen we deze fenomenen wel mee omdat ze gedragsproposities vormen die gevolg kunnen zijn van incomplete specificaties en/of contracten en van grote invloed op projectsucces kunnen zijn.

${ }^{21} \mathrm{Zie}$ ook verderop in dit hoofdstuk

${ }^{22}$ Gedrag dat projectsucces bedreigt maar voor de partij die dit gedrag vertoont wel op korter termijn optimaal is.

${ }^{23}$ Als het reputatiemechanisme een ro van betekenis speel binnen de sector (bijvoorbeeld door het op grote schaal toepassen van PPI als (nader)selectiecriterium)
Ook Parmigiani (2007) noemt opportunisme, onzekerheid, asset specificity en begrensde rationaliteit als transaction costdrivers. De laatste twee zijn volgens haar min of meer als gegeven te beschouwen bij een concreet project. Dus moet volgens haar een transactie zo ingericht worden dat onzekerheid wordt gereduceerd en opportunisme wordt ontmoedigd.

Het is moeilijk te voorspellen wie zich wanneer opportunistisch zal gedragen (Williamson ${ }^{20}, 1985$ ). Daarom wordt opportunisme voor mogelijk gehouden en zijn maatregelen om negatieve effecten ervan tegen te gaan nodig (daarnaast is het kennelijk goed het organiseren van de transactie zodanig in te richten dat opportunistische neigingen niet worden bevorderd, maar ontmoedigd ${ }^{21}$ ). Markten zijn niet volledig effectief in het verwijderen van suboptimaal gedrag ${ }^{22}$, dus komt suboptimaal gedrag voor en moet er op geanticipeerd worden. Het spreekt voor zich dat maatregelen die gericht zijn op het omgaan met opportunistisch gedrag en/of op het beperken van de gevolgen ervan, bijdragen aan hoge transactiekosten. Nooteboom introduceert de begrippen "ruimte voor" en "neiging tot" opportunisme. Feitelijk opportunisme is een functie van beide. Individuele betrouwbaarheid is moeilijk, zo niet onmogelijk vast te stellen (vertrouwen is een contra-factisch begrip; het ontbreken ervan is makkelijker aan te tonen dan de aanwezigheid ervan). Mensen streven hun eigenbelang na, schakelen daarbij eventueel ook list en bedrog in

Dorée (2001) stelt dat opdrachtgevers daardoor de behoefte hebben zich te wapenen (safeguarding) tegen opportunisme; bijvoorbeeld door het inbouwen van bonussen en malussen, inbouwen van een structuur om conflicten te reguleren en door het maken van afspraken, die intenties om dit werk en eventuele volgende opdrachten samen tot een goed einde te brengen, bevorderen. ("trading regularities that signal and support continuity intentions”, Dorée, 2001). Samenwerkingsbereidheid is voor aannemers in dit licht bezien, een soort van belegging in vervolgopdrachten (Dorée, 2001; Chiang, Tang, 2005) ${ }^{23}$.

Williamson (1985) stelt dat vergeleken bij andere economische organisatiestudies TCE meer micro analytisch is en gevoeliger is voor gedrag van actoren. Dat gedrag is van belang omdat opportunisme wordt gezien als belangrijkste veroorzaker van ex post transactiekosten (Stip, 1995). TCE is ook gevoeliger voor asset specificity (en daar is bij bouwprojec- ten in hoge mate sprake van, zie ook Bijlage v) en bovenal gevoeliger voor ex post effecten en kosten. Dit laatste is van groot belang omdat pas na contractering, wanneer partijen met elkaar aan het werk zijn, zicht verkregen wordt op feitelijke kwaliteitsniveaus, kostenniveaus, hoe soepel of hoe stroef (lees hoe weinig of hoeveel transactiekosten hiermee gemoeid zijn) het naleven van overeengekomen afspraken verloopt etc.

Deze overwegingen (meer gevoelig voor gedrag van actoren en asse specificity en meer gericht op micro economische situaties) bieden aanknopingspunten voor het verklaren van de werking van de pips elementen. Er is bij het organiseren van een transactie sprake van toepassing bij een concreet project (micro economie, en specifiek) waarbij actoren (zeker sleutelfunctionarissen) veel bewegingsvrijheid hebben binnen de projectorganisaties (besturingsstructuur) en op de daarbinnen functionerende tijdelijke samenwerkingsverbanden een stempel drukken. Projecten hebben veelal lange doorlooptijden waardoor de transactiekosten ex post aan belang winnen, naast de ex ante transactiekosten. Zoals Williamson het stelt: TCE inzichten zijn bruikbaar waar tijdelijke organisatievormen van, met en tussen organisaties worden gesloten (Williamson, 1975, 1985)

Met het complexer worden van projecten nemen de mogelijkheden om opportunistisch gedrag te vertonen toe, wat meer problemen op het vlak van contractbeheersing met zich mee brengt. Met andere woorden: er is in de hedendaagse bouw sprake van onzekere en complexe transacties die 'nooit volledig waterdicht' te contracteren zijn (Luo, 2002). Boukendour (2007) geeft aan dat niet alles is te voorzien en dat het schrijven van 'complete contracten' onbetaalbaar is en wellich zelfs onmogelijk. Contracten zijn volgens hem zelfs per definitie niet $100 \%$ dekkend, en daardoor is er een risico van contractueel ex post opportunisme. Yates \& Hardcastle (2003) noemen incomplete contracten zelfs "de sleutel" tot opportunisme. Ze pleiten met deze stellingname niet voor het nastreven van complete klassieke contracten, maar voor de benadering van relationele contracten en de daarbij op coöperatie gerichte samenwerking ${ }^{24}$. Klassieke contracten schieten in hun ogen tekort omdat clausules waarmee getracht wordt tot contractuele protectie te komen maar deels werken, kostbaar zijn en niet in alle contingenties zullen voorzien.
${ }^{24}$ Meer hierover in Bijlage $\mathrm{v}$ 


\section{Samenvattend:}

TCE biedt inzicht in de samenhang tussen directe kosten en transactiekosten. Het bewerkstelligen van de laagste som van beiden kan door het ontmoedigen van de neiging tot het vertonen van opportunistisch gedrag en door onzekerheid te reduceren. Daarnaast dient rekening gehouden te worden met begrensde rationaliteit van actoren.

\section{Principal agent theory}

Naast TCE vormt de principal agent theorie een belangrijke component van NIE (Kim \& Mahomey, 2005 die verwijzen naar Jensen \& Meckling, 1976; Holmstrom, 1979; Fama, 1980; Fama \& Jensen, 1983). De essentie van die theorie: partijen hebben verschillende doelen en belangen en beschikken niet over volledige informatie over elkaars doen en laten. De principal (opdrachtgever) weet niet of de agent (leverancier) maximaal presteert. De leverancier weet dat wel. Er is sprake van imperfecte informatie (informatie is onvolledig) en asymmetrische informatie (partijen zijn niet gelijk geïnformeerd). Beide partijen worden verondersteld hun eigen belang na te streven 'in een wereld vol onvolledige informatie'. Daarbij heeft de agent na gunning meer informatie dan de principal. Het voorkomen van al te grote informatie asymmetrie, verkleint contractuele gevaren ${ }^{25}$. Contractuele gevaren

${ }^{25}$ Deze informatie asymmetrie is vooral te verkleinen door te streven naar even-

wicht in informatieniveaus aan de zijde van de principal en de agent; niet door extra informatie toe te voegen.

${ }^{26}$ Cheung, Rowlinson, Jefferies \& Lau (2005) geven aan dat er in de bouw in toenemende mate gebruik wordt gemaakt van relationele contracten (zie daarvoor ook bijlage IV) aan sturing van het verloop van de transactie (Eisenhardt, 1989). Het aldus sturen van agents brengt uiteraard kosten met zich mee; de zoge-
heten agentschapskosten. De principal agent theorie stelt daarbij het contract centraal (TCE stelt de transactie centraal). Bij de principal agent theorie is vooral van belang dat niet alles op papier gezet kan worden en dat in de geest van het contract moet worden gehandeld ${ }^{26}$. Vertrouwen tussen partijen speelt daarbij een rol van betekenis (verderop meer over het belang van vertrouwen bij het organiseren van transacties). Het feit dat contracten van complexe projecten niet perfect zijn (kunnen niet in alle contingenties voorzien), biedt ruimte voor opportunistisch gedrag van de aannemer na gunning; of de aannemer deze 'ruimte voor' ook daadwerkelijk zal benutten hangt af van de mate waarin de belangen van de opdrachtnemer in een specifiek contract worden gediend. Di kan tot gevolg hebben dat het originele contract aangepast moet worden, inclusief daarbij behorende onderhandelingen waarbij de macht steeds meer bij de aannemer aan wie gegund is komt te liggen, hetgeen kosten verhogend kan werken. Als de 'laagste-prijs-klem' bij de aanbesteding te strak is aangedraaid ${ }^{27}$, zoekt de aannemer wellicht na gunning compensatie in de sfeer van het uitspelen van 'gaten in het bestek', het 'royaal' afprijzen van door de opdrachtgever geïnitieerd meerwerk en opportunistisch gedrag bij heronderhandelingen in geval van onvoorziene situaties (Ling, Kumaraswamy, 2005; Guccio et al, 2008).

Aannemers kunnen er zodoende de strategie op nahouden bewust laag in te schrijven (wellicht zelfs onder kostprijs) om de aanbesteding te winnen, wetende dat er na gunning nog mogelijkheden liggen om de verliezen te beperken. Met andere woorden (Dorée, 2001): afhankelijk van de verhoudingen tussen contractanten, kunnen post contractuele onderhandelingen soepel of moeizaam verlopen. Ze kunnen zich coöperatief opstellen of opportunistisch gebruik maken van de situatie. Agentschapkosten kunnen beperkt worden door een organisatievorm waarin sturing op een efficiënte wijze kan plaatsvinden door overdrach van informatie, het geven van prikkels en regels en voorschriften (Ling Kumaraswamy, 2005; Guccio et al, 2008)

De prinicipal agent theory handelt over de kosten van monitoring and bonding. Nadat het contract is gegund aan de aannemer die het project gaat realiseren, is het zaak dat de opdrachtgever (principal) borg dat de aannemer (agent) acteert zoals verwacht en overeengekomen. Daarvoor moet de principal inspanningen plegen; dat levert monitoring kosten op. De agent maakt bonding costs; hij pleegt inspanningen om de principal ervan te overtuigen dat hij in zijn belang werkt en geen activiteiten zal ontplooien en/of nalaten die dat belang mogelijk kunnen schaden (Eisenhardt, 1989).
${ }^{27}$ Anders gezegd; er is dan sprake van een opdrachtgever die opportunistisch gedrag vertoont 


\section{Principal \\ $\leftarrow$ \\ $\uparrow$ $\downarrow$ \\ Agent}

Afbeelding 3.1; Principal/Agent en Monitoring/Bondings costs

Er bestaat een wederzijdse afhankelijkheid tussen beiden, en beiden beschikken bovendien over een wisselend informatieniveau (er is sprake van informatie asymmetrie). De principal zal de agent nooit voor $100 \%$ kunnen controleren en monitoren. Dat zou bovendien de transactiekosten buitensporig laten stijgen. Kennelijk moet er dus een modus gevonden worden waarbij de mate van monitoring en bonding tot een werkbare (acceptabel risiconiveau en acceptabel kostenniveau) situatie zal leiden.

Samenvattend:

De Principal Agent theory bevat inzichten die aanvullend zijn op de transactiekosten theorie. De verhouding opdrachtgever opdrachtnemer is te zien als principaal tot agent. De beperking van monitoring- en bonding kosten en de invloed die informatie asymmetrie en 'vertrouwen' daarop hebben is van belang bij het beperken van de som van de directe en de transactiekosten.

\section{Property rights theory}

De basis voor de property rights theory is gelegd door Grossman \& Hart (1986) en Hart \& Moore (1990) die voortborduurden op de meer

klassieke basis die gelegd werd door onder andere Coase $(1959,1960)$, Alchian $(1965,1969,1972)$, Demsetz $(1964,1966,1967)$. Zie hiervoor het artikel van Kim \& Mahomey (2005) waaraan al eerder is gerefereerd. Moderne property rights theory complementeert principal agent theory en transactiekosten theorie door eigenaarschaps-concepten in te brengen in complexe contractsituaties. Kim \& Mahomey (2005) geven een omschrijving van property rights die neerkomt op: de eigendomsrechten van individuen om bepaalde eigendommen te gebruiken, eraan te verdienen en ze al dan niet in economisch verkeer uit te wisselen. De property rights theory is relevant in het kader van dit onderzoek omdat deze theorie beschrijft dat wanneer een partij eigenaar is van bepaalde properties, deze partij ander gedrag zal vertonen dan wanneer er geen sprake is van dit eigenaarschap (Williamson: "ownership matters"). Achterliggende gedachte hierbij is dat je wanneer je de (zoete of zure) vruchten zult plukken van je inspanning als directeur/eigenaar, je ander gedrag ten toon zult spreiden dan wanneer je de rol van bedrijfsleider invult. Ter illustratie: De bedrijfsleider loopt hoogstens een deel van de bonus mis, maar is verder verzekerd van zijn reguliere beloning (vast salaris). De directeur/eigenaar echter zal de waarde van zijn bedrijf zien teruglopen, de winst zien slinken; kortom hij zal waarschijnlijk enkele "extra passen zetten" om succesvol te zijn, vergeleken bij de bedrijfsleider bij wie de belangen die op het spel staan beperkter zijn. Dit fenomeen is door Williamson "shirking" genoemd; je ergens makkelijk vanaf maken (Lai, $\mathrm{Ng}$ en Yung, 2008).

\section{Samenvattend:}

De property rights theory geeft inzicht in het feit dat ownership gedrag beinvloedt. Bij het overdragen van risico's naar de opdrachtnemer (Kashiwagi: "the contractor is risk owner") en door het vergroten van betrokkenheid ("commitment"), kan op grond van deze theorie constructief gedrag worden verwacht ten aanzien van het managen van deze overgedragen risico's. Dit vergroot de kans op projectsucces en verlaagt de som van directe- en transactiekosten. 


\section{Concluderend}

NIE bestaat uit een set algemeen erkende en 'vitale' theorieën. De transactiekosten theorie, de property rights theory en de principal agent theory zijn complementair aan elkaar. De drie theorieën hebben dezelfde antecedenten en mogen volgens Kim \& Mahomey (2005) naast elkaar gebruikt worden om economische transacties te onderzoeken. Deze theorieën geven inzicht in de begrensde rationaliteit van actoren en de invloed die dat heeft op selecteren, contracteren en projectmanagement. Ook besteden deze theorieën aandacht aan de ruimte voor en neiging tot opportunistisch gedrag, en de invloed daarvan op de samenwerking. Tevens besteden deze theorieën aandacht aan het belang van het reduceren van onzekerheid, met name de combinatie van hoge onzekerheid met een zekere neiging tot het vertonen van opportunistisch gedrag dient te worden ontmoedigd. Ook de invloed die de principal en agent rol hebben op bonding- en monitoring kosten en de rollen die informatie asymmetrie en 'vertrouwen' daarbij spelen komen hierbij aan de orde. Tot slot gaat NIE ook in op het belang van demarcatie en overdracht van risico's vanuit de property rights benadering. Deze inzichten helpen bij het zodanig inrichten van aanbestedingsprocessen dat het uiteindelijke projectresultaat erbij gebaat is en de som van directe- en transactiekosten wordt verlaagd. Voor een meer uitvoeriger beschrijving van NIE zie bijlage $\mathrm{v}$.

\subsection{Opportunisme, onzekerheid, safeguarding, begrensde}

\section{rationaliteit en vertrouwen}

Het gaat er volgens NIE om transacties zodanig te organiseren dat de som van productie- en transactiekosten zo laag mogelijk is. Volgens Williamson worden transactiekosten bepaald door:

- Transactietype (Williamson onderscheidt zes transactietypen ${ }^{28}$ geordend naar frequentie van transacties vanuit het opdrachtgevers perspectief én specificiteit van activa)

- Risico van opportunisme (wordt bepaald door alignment of goals en vormgeving contract)

- Mate van onzekerheid (gerelateerd aan kans op opportunisme en mede bepaald door begrensde rationaliteit)

Bouwprojecten zijn doorgaans te typeren door een lage frequentie ${ }^{29}$, een hoge specificiteit, een hoge mate van onzekerheid en een zeker risico op het optreden van opportunistisch gedrag na gunning. Specificiteit en frequentie zijn als gegeven te beschouwen bij een specifieke transactie. De mate van onzekerheid en het risico van optreden van opportunistisch gedrag kan met behulp van NIE begrepen worden en daardoor beïnvloed worden.

\section{Opportunisme}

Omdat bij het aanbesteden van complexe projecten sprake is van onzekerheid en opportunistisch gedrag kan optreden (onder andere vanwege begrensde rationaliteit, kans op opportunisme, onzekerheid, informatie asymmetrie, imperfecte contracten) speelt het fenomeen vertrouwen (lees voorspelbaarheid) ook in de transactiekosten economie een belangrijke rol. Bromiley \& Cummings (1995) geven aan dat samenwerkingsrelaties die op vertrouwen gebaseerd zijn 'voordeliger' zijn omdat ze leiden tot lagere kosten, kortere doorlooptijden en kwaliteits- en performance verbetering. Ook Dainty, Briscoe \& Millet (2001) onderschrijven het belang van een meer op coöperatie gericht samenwerkingsconstruct in hun artikel "Subcontractors perspectives on supply chain alliances". Ze verwachten vooral resultaten van verbeterde interactie tussen opdrachtgever en contractor(s) en het aangaan van alliances en partnerships. Dorée stelt dat het voor de ontwikkeling van de nieuwe bouwpraktijk van belang is de scherpe kanten van de competitie af te snijden, en werkbare vormen te vinden voor interactie en co-development. Chan, Chan \& Ho (2003) bevestigen evenzo de positieve effecten van samenwerkingsconstructen die zijn geënt op meer coöperatie. In hun artikel "An empirical study of the benefits of construction partnering in Hong Kong" stellen ze dat goede en actieve partnering van alle betrokken partijen bijgedragen heeft aan tijdig en binnen budget opleveren, met een minimum aan conflicten, claims en fouten. Ook Thamhaim \& Wilemon (1987) stellen dat mee vertrouwen leidt tot betere projectresultaten. Want, zo redeneren ze, in een setting waarin vertrouwen heerst, wordt informatie open en royaal gedeeld en worden er 'geen spelletjes gespeeld'. Als er meer
${ }^{29}$ Voor menig opdrachtnemer geldt dat hij frequent met bouwprojecten wordt geconfronteerd, voor veel opdrachtgevers is dat slechts incidenteel het geval. Laat onverlet dat elk (uniek) project an sich een laag frequent karakter kent. 
vertrouwen heerst, zal de kwaliteit van informatiedeling hoger liggen, zodat er betere informatie beschikbaar is, die gebruikt kan worden om juiste beslissingen te kunnen nemen. Dat komt projectresultaat ten goede (zie ook IMT eerder in dit hoofdstuk).

Williamson (1985) stelt dat het transactiekostenmodel niet zonder wederzijds vertrouwen kan, wanneer de doelstelling is het welbevinden van beide partners te dienen. In een situatie waarin één partner ervoor kiest niet vanuit vertrouwen te handelen, ligt opportunisme op de loer, wat in bouwprojecten tendeert naar vijandig in plaats van coöperatief gedrag. Hierbij onderscheidt Williamson twee driifveren voor vertrouwen: selforiented trust en socially oriented trust. In het eerste geval wordt de drijfveer gevormd door wat de andere partij voor mij zou kunnen betekenen. In het tweede geval wordt de drijfveer gevormd door wat ik voor die andere partij zou kunnen betekenen. Deze laatste drijfveer zal minder vaak voorkomen in combinatie met opportunistisch gedrag (Edkins \& Smyth, 2006). Gambetta (1998) stelt zelfs dat vertrouwen een voorwaarde is om überhaupt te kunnen samenwerken. 'Bouwen aan vertrouwen' (vergroten voorspelbaarheid, verkleinen onzekerheid) zal bijdragen aan het verkleinen van de neiging tot opportunisme.

Vertrouwen (tussen principal and agent) is tevens belangrijk vanwege het feit dat niet alles vooraf bekend is ("bouwen is het kopen van een belofte") en er dus onzekerheid in elk project bestaat (Goddard \& Manion, 1998; Jin \& Ling, 2005). Vertrouwen kan feitelijk als tegen hanger van opportunisme worden gezien (Dorée, 1996). Wood \&

McDermott (1999) definiëren vertrouwen als de bereidheid te bouwen op de acties van anderen, afhankelijk van hen te zijn en dus een zekere kwetsbaarheid te hebben ten aanzien van hun doen en laten. Williamson en Gambetta leggen een link tussen vertrouwen en de hoogte van transactiekosten. Vertrouwen is een belangrijk smeermiddel, het werkt erg efficiëntie verhogend; als er genoeg van is, bespaart dat mensen veel problemen omdat een redelijke mate van betrouwbaarheid ontleend kan worden aan toezeggingen van anderen (Thamhain, Wilemon, 1987). Economische relaties die gebaseerd zijn op een hoge mate van vertrouwen, zijn efficiënt (Eriksson, Pesamaa, 2007). Wanneer er sprake is van een hoge mate van vertrouwen tussen partijen, zal dat leiden tot lage transactiekosten bij het contracteren en monitoren van de op basis van de overeengekomen contracten te verwachten performance. Dirks
(1999) vindt soortgelijke resultaten: teams waarin meer vertrouwen heerst, werken efficiënter, beter gecoördineerd en brengen betere output voort dan teams waarin minder vertrouwen heerst. Goddard \&

Mannion (1998) onderscheiden drie soorten van vertrouwen:

nr $1 \quad$ Contractual trust

Zullen partijen het contract naleven?

nr 2 Competence trust

Hoe waarschijnlijk is het dat de partij waar mee ik in zee ga ook competent zal blijken?

\section{nr 3 Goodwill trust}

Hoe waarschijnlijk is het dat de partij waar mee ik in zee ga bereid is initiatieven te nemen en "een pas extra te zetten" om zaken die niet contractueel voorzien zijn, tot een goede oplossing te brengen?

Meer vertrouwen op alle drie deze dimensies, leidt tot geringere neiging tot het vertonen van opportunistisch gedrag en daarmee tot reductie van onzekerheid.

Vertrouwen speelt een grotere rol naarmate onzekerheid en specificiteit een grotere rol spelen (Drexler \& Larson, 2000). Daarnaast is het zo dat hoe groter de onzekerheid, hoe meer nadelige effecten je van begrensde rationaliteit zult ervaren. Anders gezegd: onzekerheid ${ }^{30}$ an sich is nie zo een probleem, maar in combinatie met opportunisme (als tegen-

hanger van vertrouwen!) wordt het pas een probleem (Williamson, 1985). Jin en Ling (2005) hebben de relatie tussen vertrouwen en risico ${ }^{31}$ uitgebreid onderzocht. Ze concluderen dat als er geen risico is, er ook geen vertrouwen nodig is. Als er meer risico is, is de behoefte aan vertrouwen groter. Risicoreductie maakt dat er minder behoefte aan (het moeilijk grijpbare begrip) vertrouwen is. Ze noemen een aanta remedies om risico's (en daarmee samenhangend onzekerheid) te reduceren. Bij de selectie van partijen ook aandacht besteden aan samenwerkingsvermogen is er daar een van. Deze aannemers vroeg
${ }^{30}$ Begrensde rationaliteit mondt onzekerheid; ofwel door het nemen van verkeerde beslissingen, ofwel door het niet goed interpreteren en verwerken van informatie.

${ }^{31}$ Risico en onzekerheid houden direct met elkaar verband. Risico $=$ kans $\mathrm{x}$ effect; de kans vormt de onzekere factor. 
${ }^{32}$ Zoals in hoofdstuk twee is beschreven, hanteert pips deze remedies. Verderop in dit hoofdstuk wordt hierop nog uitgebreid teruggekomen.

${ }^{33} \mathrm{Na}$ gunning van de opdracht.

${ }^{34}$ Opportunistisch gedrag is overigens aan de zijde van opdrachtgever en opdrachtnemer mogelijk. Zie hiervoor ook hoofdstuk zes.

\section{${ }^{n r} 1 \quad$ Belonings- en straf procedures;}

\section{$n r 2$ Conflictregulering;}

\section{${ }^{n r} 3$ Continuïteitsondersteunende mechanismen;}

Belonings en straf procedures zijn safeguards die de hoogte van de tegenprestatie van een partij kunnen beïnvloeden. Conflictregulering wordt bereikt door safeguards die bijdragen aan het voorkomen van conflicten en het beperken van (escalerende) gevolgen van conflicten. Continuiteitsondersteunende mechanismen tenslotte, zijn safeguards die gericht zijn op het laten prevaleren van belangen op een langere termijn, zoals bijvoorbeeld belangen in het kader van kansen op toekomstig werk

Geyskens, Steenkamp en Humar tonen in hun artikel "make, buy or ally" aan dat het zaak is transacties (type c; zie Bijlage v) waarbij sprake is van onzekerheid en specificiteit zodanig te organiseren dat opportunisme ontmoedigd wordt, en belangen dus meer in lijn met elkaar liggen, de begrensde rationaliteit slechts in geringe mate tot nadelige effecten zal leiden en aan wederzijds vertrouwen wordt gebouwd. De auteurs zien verticale integratie als oplossingsrichting voor het safeguarding problem dat speelt bij transactie specifieke zaken als bouwwerken. Verticale integratie is hier te interpreteren als maatregelen die er op gericht zijn taken in de bedrijfskolom zodanig te verdelen dat er meer gefocused wordt op gezamenlijke belangen; conflictregulerende en continuiteits ondersteunende safeguards dus.

Bresnen \& Marshall (2000) citeren:

"It appears to be almost universally accepted that partnering requires: changing traditional relationships to a shared culture...based upon trust, dedication to common goals, and an understanding of each other's individual expectations and values" (pagina 232)

Dit citaat onderschrijft het belang van een samenwerkingsconstruct dat opportunisme ontmoedigt (en daarmee ook onzekerheid reduceert), wederzijds vertrouwen bevordert en waarin begrensde rationaliteit slechts in geringe mate zal leiden tot nadelige effecten. Ook deze auteurs gaan in op de bijdragen die het doelgericht toepassen van safeguards heeft op het reduceren van ongewenst gedrag en het bevorderen van gewenst gedrag. In hun visie is een mix van de drie categorieën safeguards hiertoe de aangewezen oplossing. Want, zo luidt hun redenering, partnering kan alleen succesvol gedijen als beide partijen beter worden van de samenwerking (win-win in plaats van loose-loose; belonings-safeguards), belangen zodanig matchen dat conflicten niet veel voorkomen danwel goed oplosbaar zijn (conflictregulerende safeguards) en er uitzicht is op voortzetting van de profijtelijke situatie (safeguards die continuiteitsondersteunend werken).

Ook Greenwood \& Yates (2006) komen tot de conclusie dat het bevorderen van samenwerking positieve effecten heeft op projectresultaten $\mathrm{Zij}$ onderzochten 85 projecten die aan de hand van een partnering 
agreement zijn gemanaged. 80\% van deze projecten scoorden vergeleken met een traditionele benadering beter qua tevredenheid bij de opdrachtgever. Faalkosten pakten significant lager uit en projectkosten lagen ca. $20 \%$ onder het niveau dat voor vergelijkbare projecten gebruikelijk was. Het toepassen van safeguards die gericht zijn op belonen komen in dit onderzoek prominent naar voren als verklaring voor het uitblijven van opportunistisch gedrag. Singh (2002) toont aan dat projecten die zijn gebaseerd op partnering $25 \%$ beter scoren op 10 factoren (eenduidige verwachtingen, commitment, communicatie, moed, onbetwist vakwerk, verantwoordelijkheid, bereidheid tot delen, synergie, vertrouwen en respect) dan traditionele projecten

Dyer (1997) heeft in zijn studie naar verschillen in transactiekosten niveaus tussen Japanse en Amerikaanse automotive suppliers aangetoond dat een van de vijf factoren die deze verschillen verklaren (naast verschillen in schaalgrootte, informatiedeling, investeringsniveau's en commitment) betrekking heeft op de mix van safeguards die toegepast zijn. Hij brengt daarbij een nieuw element in: naast het hanteren van contractuele safeguards maakt zijn onderzoek duidelijk dat self enforcing safeguards effectiever zijn dan de eerst genoemde categorie. Hiermee doelt hij op relationeel vertrouwen, maar ook op het verantwoordelijk maken van suppliers voor bijvoorbeeld voorraden ( financial hostage). Met deze self enforcing safeguards brengt hij een variant in op de eerder genoemde continuiteitsondersteunende safeguards. De pips safeguards zijn overigens, zoals verderop zal blijken, ook meer self enforcing dan contractual.

\section{Samenvattend:}

Bij het aanbesteden, contracteren en managen van bouwprojecten is er sprake van onzekerheid ("je koopt een belofte" en de begrensde rationaliteit van actoren brengt ook onzekerheid met zich mee) en tevens is er een kans dat een of meer partijen zich opportunistisch gaat gedragen. Daarom verdient het aanbeveling safeguards te hanteren (die onzekerheid reduceren, rekening houden met begrensde rationaliteit van actoren en de neiging tot opportunistisch gedrag ontmoedigen) en te 'bouwen aan vertrouwen'.

\subsection{De link tussen Pips en NIE mechanismen}

Centrale vraag in deze paragraaf is in hoeverre is de werking van pips vanuit NIE te verklaren? Deze vraag is positief te beantwoorden als uit het verbinden ${ }^{35}$ van Pips met de NIE mechanismen blijkt dat pips onzekerheid reduceert, de neiging tot opportunistisch gedrag ontmoedigt, inspeelt op de begrensde rationaliteit van actoren en alignment of goals bevordert (waardoor coöperatie makkelijker en constructiever zal verlopen). Ook zal duidelijk gemaakt moeten worden hoe pips dat doet.

Overigens is het realistisch ervan uit te gaan dat projectresultaten nie alleen beïnvloed worden door toepassing van de pips elementen. Ook andere factoren kunnen en zullen een rol spelen zoals marktomstandigheden, persoonlijke verhoudingen, lokale omstandigheden in en rond het project etcetera. Dit besef dient onverkort te worden meegenomen

bij het interpreteren van de volgende paragrafen.

Zoals uit voorgaande paragrafen blijkt zijn de belangrijkste NIE mechanismen:

A Het reduceren van onzekerheid door onder andere het beschikbaar hebben van meer relevante informatie en het creëren van commitment

B Het ontmoedigen van de neiging tot het vertonen van opportunistisch gedrag door het evenwichtig dienen van belangen van opdrachtgever en opdrachtnemer (alignment of goals) waardoor cooperatie wordt bevorderd.

- B1: ontmoedigen van de neiging tot het vertonen van opportunistisch gedrag

- B2: bevorderen van alignment of goals

- B3: het bevorderen van coöperatie

Het inspelen op/rekening houden met de begrensde rationaliteit van actoren.

In deze paragraaf wordt inzichtelijk gemaakt of en in welke mate pips
${ }^{35}$ Door middel van logische redeneringen. 
deze NIE mechanismen volgt casu quo gebruikt.

\section{A Reduceert pips onzekerheid, en hoe werkt dat dan?}

pirs hanteert zeven filters, zoals beschreven in hoofdstuk twee. Dit betekent onder andere dat er meer informatie beschikbaar is over in het verleden geleverde prestaties, over risico's (en over hoe daarmee om te gaan) en over de kwaliteit van sleutelfunctionarissen.

Als aanbesteder koop je een 'belofte' als je aanbesteedt. Een aanbesteder heeft zo beschouwd baat bij het reduceren van onzekerheden. pips werkt systematisch aan het reduceren van onzekerheid door genoemde zeven filters te hanteren die ertoe leiden dat de partij geselecteerd wordt die het project op een coöperatieve wijze tot een goed einde kan brengen

${ }^{36}$ Ontleend aan van Weele, inkoop in strategisch perspectief ISBN 9014056206

${ }^{37}$ Het vanuit de beoogde functie van een bouwwerk nadenken over outputspecificaties 'dwingt' de opdrachtgever heel bewust na te denken over aard, omvang, frequentie, kwaliteitsniveau van de verschillende onderdelen die bij moeten dragen aan de beoogde functionaliteiten. Het op deze wijze nadenken over de behoeften blijkt in de praktijk overigens zeker niet eenvoudiger te zijn. warbij voldaan wordt aan financiële, planningstechnische en kwaliteitsafspraken. Graafland en Nijhof (2007) tonen aan dat innovatieve aanpakken zoals pips alignment of goals bevorderen (het meer in elkaars verlengde liggen van doelstellingen van opdrachtgever en opdrachtnemer) en daarmee bijdragen aan commitment, vertrouwen en een besef dat beide partijen afhankelijk zijn van elkaars performance om enten kwaliteit te optimaliseren. pips reduceert drie soorten onzekerheid ${ }^{36}$

$n r$

Op de eerste plaats reduceert pips marktonzekerheid; pips werkt stelselmatig aan het zodanig filteren van gegadigden, dat gericht gezocht wordt naar de meest geschikte partij. Het mee laten wegen van Past Performance Information, het Risk Assessment Value Added, het interviewen van sleutelfunctionarissen en het in te dienen projectplan, draagt daaraan bij. Deze pips elementen zorgen immers voor meer informatie over het van een marktpartij te verwachten prestatie niveau.

$n r 2$ De tweede vorm van onzekerheid die pips reduceert is behoefteonzekerheid; nadenken over je behoefte in termen van (functionele) specificaties, verkleint de behoefteonzekerheid (kopen we wel het juiste; dat wat we ook werkelijk nodig hebben?) ${ }^{37}$. Daarnaast maakt zo een oplossingsvrije specificatie de aanbesteding opener (het is niet uitgesloten dat de beste aanbiedingen 'verrassende' oplossingen bevatten) en bevordert het hanteren van een oplossingsvrije specificatie concurrentie op waarde.

$n r 3$ Als derde en laatste reduceert pips transactieonzekerheid. Transactieonzekerheid gaat over de vraag of de opdrachtnemer wel in overeenstemming met de gemaakte afspraken en gewekte verwachtingen zal presteren. Door Past

Performance Information (het reputatiemechanisme doet zijn werk), Risk Assessment Value Added (de aannemer heeft vooraf al aangegeven hoe hij in voorkomende gevallen zal acteren; dat maakt een en ander een stuk minder vrijblijvend), de interviews met sleutelfunctionarissen (er wordt dus mede geselecteerd op samenwerkingsvermogen en op voor het project relevante competenties) door zijn eigen inbreng (de aannemer zal achter de door hem zelf ingebrachte oplossing staan) én de risk transfer (ownership matters) draagt pips bij aan het reduceren van deze vorm van onzekerheid. Tijdens de pre-award fase wordt eveneens onzekerheid gereduceerd doordat een gedetailleerde check plaatsvindt omtrent de match tussen vraag en aanbod (centrale toetsvraag: biedt de aangeboden oplossing een passend en dekkend antwoord op de gestelde vraag?). Ook het na gunning monitoren van de prestaties (performance meting en sturing) draagt bij aan reductie van transactieonzekerheid.

Door vooraf informatie te verstrekken over het beschikbare budget stelt pips high performers in de gelegenheid value for money te bieden binnen de financiele kaders zoals door de opdrachtgever gesteld.

Inschrijvers kunnen daardoor heel gericht toe werken naar een voorstel/ oplossing dat toegevoegde waarde aan de gevraagde functionaliteiten verbindt binnen de financiële grenzen van wat de opdrachtgever zich kan veroorloven. Dat verlaagt transactiekosten én reduceert onzekerheid. De neiging tot het vertonen van opportunistisch gedrag wordt onderdrukt, want als je jezelf kwalitatief onderscheidt terwijl je binnen 
${ }^{38}$ Zonder daarvoor de belangen van de opdrachtgever te hoeven schaden. de budgetgrenzen blijft, vergroot je daarmee de scoringskans gekoppeld aan de mogelijkheid een redelijke marge te realiseren ${ }^{38}$. Een goed plan (dat een optimaal antwoord op de gestelde vraag biedt) met een faire prijsstelling biedt bij deze Best Value Procurement (BVP) aanpak de beste kans om te winnen. Daardoor komen marktpartijen na gunning niet in de verleiding naar een redelijke marge toe te werken ten koste van de belangen van de opdrachtgever. pips motiveert en stimuleert aannemers om op een zo hoog mogelijk kwaliteitsniveau te presteren. Een hoog prestatieniveau leidt immers tot een hoge ranking. Een hoge ranking draagt bij aan het verwerven van nieuwe opdrachten.

Partijen die geen kans zien het gevraagde aan te bieden binnen het aangegeven budgetplafond, doen een ongeldige inschrijving (deze inschrijvingen kunnen om deze reden terzijde worden gelegd). De focus ligt niet langer op laagste kosten, de focus ligt op waarde. De focus op laagste kosten impliceert een hoger risico niveau, dan de waardefocus. De focus op laagste prijs bevordert namelijk dat marktpartijen de gespecificeerde zaken als bovengrens hanteren en zich buigen over de vraag hoe deze grens tegen minimale kosten is te bereiken (Kashiwagi, 2004 Cheung et al, 2005; Kadefors, 2005). De waardefocus reduceert daarnaast onzekerheid met betrekking tot het respecteren van het budgetplafond. Ook werkt pips zoals al eerder gesteld, bij voorkeur met een oplossingsvrije specificatie en laat daardoor ruimte voor inbreng van/ door aanbieders. Dat dit tot positieve effecten voor projectresultaten leidt, wordt inmiddels algemeen aanvaard (Jansen, 2001 en PSiBouw 2005 en 2006, de Schipper, 2005)

Tijdens de aanbesteding en tijdens de bouw, is er bij de pips aanpak informatie beschikbaar over voormalige en huidige performance.

Dat draagt bij aan transparantie, objectiviteit en resultaatgerich projectmanagement. 'Meten is weten' verkleint onzekerheid. Er is meer informatie beschikbaar met meer voorspellende waarde over te verwachten performance en ook meer informatie beschikbaar over feitelijke performance ten aanzien van planning, budget en kwaliteit (tijdens de uitvoering). Aannemers worden door pips uitgedaagd hun vakmanschap in te zetten om de oplossingsvrij gespecificeerde vraag te vertalen naar een oplossing binnen budget die een positief onder- scheidende 'waarde' in zich heeft. Behalve dat dit waardeverhogend kan werken, leidt het ook tot minder onzekerheid. De kans dat de aanneme zijn eigen oplossing adequaat kan realiseren is immers groter dan dat hij de oplossing die een ander heeft bedacht en uitgewerkt adequaat kan realiseren. Tenslotte bevordert pips de kwaliteit van de samenwer king. Er is aandacht voor de belangen van opdrachtgever en opdrachtnemer. Dit leidt tot betere samenwerking en betere samenwerking reduceert onzekerheid (Bresnen \& Marshall, 200o)

\section{Concluderend:}

PiPs reduceert in hoge mate onzekerheid voor opdrachtgever en opdrachtnemer. Er is immers meer en beter geobjectiveerde informatie beschikbaar (de kans dat je een incompetente marktpartij contracteert wordt daardoor verkleind; ook de opdrachtnemer heeft meer vertrouwen in de goede afloop van het project doordat hij het project naar zijn hand heeft kunnen zetten en vroeger

betrokken is), de focus op waarde (in plaats van op laagste prijs) verkleint risico's, aannemers krijgen de ruimte een project naar hun hand te zetten en vanuit het praktijkperspectief inbreng te hebben bij de voorbereiding van het project. Aannemers zijn daardoor meer, en voelen zich ook meer, betrokken bij het project. Ook de check tijdens de pre-award fase en het tijdens de uitvoering monitoren van de performance dragen bij aan reductie van onzekerheid.

\section{B1 Ontmoedigt pips de neiging tot opportunistisch gedrag en hoe} werkt dat dan?

pips verlaat de 'laagste-prijs-klem'. Daardoor wordt de neiging tot opportunistisch gedrag na gunning ontmoedigd (Sijpersma, 2007).

De neiging om na gunning opportunistisch gedrag te vertonen is bij de pips aanpak in mindere mate aanwezig, omdat er ook aandacht is voor de noden en belangen van de opdrachtnemer (alignment of goals) Door te streven naar een zogenaamde win - win situatie (vergelijk dit met de traditionele aanpak die als loose - loose wordt gekarakteriseerd) kan de aannemer zich concentreren op het leveren van vakwerk volgens planning; hij hoeft zich als hij professioneel en dientengevolge efficiën werkt geen zorgen te maken om zijn financiële projectresultaat. Aanbestedingen die te competitief zijn (dominante focus op laagste prijs), nodigen aannemers niet uit te investeren in 'reputatie'; ze kunnen zich 
immers alleen onderscheiden door laagste prijs. Het gebruik van Past Performance Information (PPI) draagt dan ook bij aan reductie van de transactieonzekerheid. Na gunning zal de aannemer het imago op grond waarvan hij mede is gecontracteerd, waar willen maken (het reputatiemechanisme). Dat is immers ook in zijn eigen belang met het oog op de kans op toekomstig werk. Ook hierdoor wordt de neiging tot opportunistisch gedrag onderdrukt. Graafland en Nijhof (2007) hebben gepubliceerd over het verband tussen het zogenaamde reputatiemechanisme en opportunistisch gedrag. Zij tonen aan dat wanneer er meer informatie beschikbaar is over prestaties uit het verleden, dat tot meer vertrouwen leidt. Zoals al eerder beschreven, zijn opportunisme en vertrouwen elkaars tegenhangers. Hieruit valt af te leiden dat het hanteren van het reputatiemechanisme (zoals pips ook doet) inderdaad bijdraagt aan het reduceren van opportunistisch gedrag. Ook

Nooteboom (1992) komt in zijn onderzoek tot de conclusie dat in een systeem waarin goede (past) performance bijdraagt aan betere kansen op vervolgopdrachten (of toekomstig werk in het algemeen) betere samenwerking is te verwachten ("contractors expecting repeat business will cooperate"). Het gebruik van pips elementen als PPI en de Post Construction Rating leggen een expliciete link met het prestatieniveau en de kans op toekomstig werk. Het reputatiemechanisme ontmoedigt dus opportunistisch gedrag en draagt daardoor bij aan projectsucces. Daarmee draagt deze aanpak bij aan professionalisering van de sector, terwijl de traditionele aanpak deze professionalisering juist remt.

Aannemers worden ook vroeger in het proces betrokken en kunnen daardoor waarde toevoegen. Dat zal leiden tot meer commitment: zaken als identificatie met de oplossing en trots spelen een rol. pips daagt aannemers namelijk uit hun vakmanschap en kennis in te zetten (Bijsterveld, 2005). Partijen die zich uitgedaagd voelen, zullen minder snel opportunistisch gedrag vertonen. Er wordt immers geappelleerd aan zaken waar ze hun trots aan ontlenen. Daardoor leidt meer commitment tot ontmoediging van de neiging tot opportunistisch gedrag.

Door het hanteren van interviews met sleutelfunctionarissen, Risk Assessment Value Added and Past Performance Information, wordt de voorspelbaarheid van de aanbesteding vergroot (er is immers meer informatie beschikbaar die aangewend kan worden voor het maken van keuzes). Deze grotere voorspelbaarheid leidt tot meer vertrouwen. Meer vertrouwen ontmoedigt opportunisme (Williamson: "opportunisme en vertrouwen zijn elkaars tegenpolen") en bevordert de kwaliteit van de samenwerking. Eriksson en Pesamaa (2007) bevestigen dat meer vertrouwen tussen opdrachtgever en opdrachtnemer neerkomt op een geringere behoefte aan monitoring en controle, omdat er meer kan worden vertrouwd op self control. Daarom is het zinvol bij een aanbesteding meer aandacht te besteden aan zaken die informatie verschaffen over de voorspelbaarheid van gedrag (Past Performance Information, Interviews, Risk Assessment Value Added).

Lau \& Rowlinson (2005) stellen dat wanneer onzekerheden afnemen en de neiging tot opportunistisch gedrag afneemt, dat zal leiden tot een mindere noodzaak om elkaars gedrag te controleren, minder noodzaak tot formele controles/inspecties, lagere kosten, minder vertragingen, het delen van kennis en resources (in plaats van het 'voor zich houden wat in traditionele settings vaak de boventoon voert), snellere en betere oplossingen voor zich voordoende knelpunten en minder papierwerk. Deze effecten lopen nagenoeg geheel parallel met de geclaimde (en in de praktijk goeddeels ook zo optredende) pips effecten. Het optreden van deze effecten is zoals uit de eerder aangehaalde onderzoeken blijkt toe te schrijven aan de NIE mechanismen.

\section{Concluderend:}

pips ontmoedigt de neiging tot opportunistisch gedrag. De waardefocus in plaats van de 'laagste-prijs-klem' levert hieraan een belangrijke bijdrage. Ook leidt pips tot meer commitment (vroegere betrokkenheid en de ruimte voor eigen inbreng) bij de opdrachtnemer hetgeen opportunistisch gedrag na gunning afremt. Ook het appèl dat PIPS doet op vakmanschap en op het 'reputatiemechanisme' draagt bij aan het ontmoedigen van opportunistisch gedrag.

\section{B2 Bevordert pips alignment of goals en hoe werkt dat dan?} pips verlaat de 'laagste-prijs-klem'. Dat stelt de gecontracteerde aannemer in principe in de gelegenheid een faire en bedrijfseconomisch verantwoorde marge te kunnen realiseren. Omdat kwaliteit zwaarde weegt dan prijs (de beste oplossing wint dus in plaats van de goedkoop ste), de aannemer in een vroeg stadium betrokken is, het project naa 
zijn hand kan zetten, op voorhand al nagedacht heeft over risico's en bijbehorende remedies, heeft de aannemer bij professionele uitvoering de mogelijkheid een faire marge te maken. Daardoor kan hij zich

focussen op de belangen van de opdrachtgever. pips daagt opdrachtnemers uit zich te onderscheiden door een kwalitatief goede oplossing in te dienen. Daarmee worden de belangen van opdrachtgever én opdrachtnemer gediend. De opdrachtgever krijgt meer value for money. De opdrachtnemer verhoogt daardoor zijn kans op succes. Doordat de opdrachtnemer veel inbreng heeft in het project, wordt het ook meer 'zijn project'. Betrokkenheid, commitment nemen daardoor toe. Doelstellingen komen daardoor veel meer in elkaars verlengde te liggen (alignment of goals).

\section{Concluderend:}

De Pips aanpak draagt ertoe bij dat belangen van opdrachtgever en opdrachtnemer meer in elkaars verlengde komen te liggen (meer gericht op het bevorderen van coöperatie) in vergelijking met de traditionele setting (meer gericht op het bevorderen van competitie). Dit effect wordt, naast de waardefocus, veroorzaakt door de vroegere betrokkenheid van de aannemer en zijn grotere inbreng in het project. Dit bevordert commitment waardoor de aannemer zich meer verantwoordelijk zal voelen en daardoor bereid zal zijn een grotere inspanning te leveren ten behoeve van het eindresultaat in het algemeen en opdrachtgeverstevredenheid in het bijzonder.

\section{B3 Is pips gericht op het bevorderen van coöperatie, en hoe werkt} dat dan?

Bij het aanbesteden van complexe projecten in de bouw, is er sprake van onzekerheid, specificiteit, begrensde rationaliteit en een zekere neiging tot opportunistisch gedrag. Daarom is governance erg belangrijk (Williamson, 1985). Deze governance werkt constructiever naarmate ze meer gericht is op het bevorderen van coöperatie (zie ook eerder aangehaalde onderzoeken van Rahman \& Kumaraswamy, Bresnen, Dainty, Briscoe \& Millet en Chan, Chan \& Ho). Ook Latham (1994) concludeert dat goede samenwerking veel van de problemen die geassocieerd worden met traditioneel aanbestede projecten (gunnen op laagste prijs en partijen denken in plaats van partnerdenken) kan ondervangen waardoor betere projectresultaten binnen bereik komen. Bennet \& Jayes
(1998) indiceren zelfs dat goede samenwerking in extreme situaties tot een kostenreductie van $40 \%$ kan leiden en de planning kan halveren. Ook Bresnen (1991) benadrukt het belang van het erkennen van individuele drijfveren en belangen van deelnemers. Hun motieven, verwachtingen en zingeving beïnvloeden systematisch hun doen en laten. Er moet volgens Bresnen dus gekozen worden voor een aanpak die samenwerking bevordert en opportunistisch gedrag ontmoedigt. pips vergroot betrokkenheid en commitment doordat opdrachtnemer vroeg ingeschakeld worden (Greenwood \& Yates, 2006; Schippers \& Broekhuizen, 2006) en sleutelfunctionarissen uit de anonimiteit worden gehaald door ze te interviewen en mee te laten denken over de aanbieding. De oplossingsvrije specificatie stelt ze in staat het project naar hun hand te zetten en hun vakmanschap in te brengen. Daardoor ontstaat er in grotere mate een ownership gevoel. Grotere betrokkenheid en meer commitment dragen via het beter op elkaar afstemmen van belangen bij aan betere samenwerking. Het verlaten van de 'laagsteprijs-klem' vormt een belangrijk aspect dat bijdraagt aan een goede samenwerkingssetting (van den Berg \& Kamminga, 2006). Bij een Pips project is er geen sprake van 'uitknijpen' aan de zijde van de opdrachtgever en 'terugpakken' aan de zijde van de opdrachtnemer. Greenwood \& Yates (2006) beschrijven dat het 'uitknijpen' en 'terugpakken' funest is voor projectsucces. Dit blijkt uit hun onderzoeksresultaten naar aanleiding van het volgen van 85 partnering agreement projecten. Bij deze projecten hadden aannemers in een vroeg stadium zekerheid over financiële aspecten. Ze wisten dat besparingen 50/50 verdeeld zouden worden en welke procentuele marges ze zouden genereren. Dit heeft volgens Greenwood bijgedragen aan de mate en kwaliteit van coöperatie. Een bevestiging van de pips aanpak: focus niet eenzijdig op laagste prijs, maar geef aannemers de gelegenheid een reële marge te verdienen waardoor de neiging tot opportunistisch gedrag wordt ontmoedigd.

\section{Concluderend:}

PiPs bevordert samenwerking door reputaties (past performances) van partijen mee te laten wegen, door partijen vroeger te betrekken, sleutelfunctionarissen uit de anonimiteit te halen, het project naar hun hand te laten zetten, dominant op kwaliteit te sturen, risico overdracht en alignment of goals. Toepassing van PiPs elementen is gericht op het bevorderen van coöperatie. 


\section{Speelt pips adequaat in op de begrensde rationaliteit van} actoren en hoe werkt dat dan?

Begrensde rationaliteit van actoren dient als onontkoombare conditie te worden beschouwd (Simon, 1945; Dorée, 2004; Greenwood \& Yates, 2006). pips is dus ook niet in staat begrensde rationaliteit an sich te beïnvloeden. Wel is het zo dat bij de pips aanpak alleen informatie in ogenschouw wordt genomen die onderscheidend vermogen oplevert. Deze informatie wordt op eenduidige wijze vertaald in countable numbers waarbij het rekenwerk geautomatiseerd is. Dit maakt dat beoordelaars zich kunnen focussen op informatie die er toe doet (onderscheidend vermogen indiceert) wat efficiënt werkt, waardoor tevens rekening wordt gehouden met het begrensde vermogen van actoren om informatie te verwerken. Daarnaast hecht pips waarde aan een efficiënt procesverloop zonder 'ballastinformatie' waardoor de transactiekosten ex ante en ex post laag zijn. Transactiekosten ex post blijven laag doordat er minder controle nodig is (lagere monitoring en bonding costs) omdat de opdrachtnemer zelf voor wekelijkse stuurinformatie zorgt op basis van harde Performance Data. Tijdens de bouw wordt er namelijk een wekelijks risk number ${ }^{39}$ overlegd en blijft de
${ }^{39}$ Dit getal vormt een afspiegeling van budget-, planningsen kwaliteitsbewaking. information environment in stand waardoor pips ook tijdens de bouw rekening houdt met begrensde rationaliteit. Dit verlaagt tevens transactiekosten en verhoogt de objectiviteit. pips beïnvloedt dus niet de mate van begrensde rationaliteit, maar wel kan begrensde rationaliteit minder kwaad, heeft minder negatieve consequenties door de pips werkwijze.

\section{Concluderend:}

PiPs focust op relevante en geobjectiveerde informatie en is gericht op het beperken van de omvang van te verwerken documenten. Dit speelt zowel tijdens de aanbesteding als tijdens de uitvoeringsfase van de bouw. Pips maakt beoordelingen zo veel mogelijk countable. Pips houdt op deze wijze rekening met (als gegeven te beschouwen) begrensde rationaliteit van actoren.

In Bijlage vi is samenvattend in tabelvorm weergegeven wat de invloed van pips elementen is op het reduceren van onzekerheid, het omgaan met begrensde rationaliteit en de mate waarin de neiging tot opportu- nistisch gedrag aanwezig zal zijn. Deze drie NIE mechanismen gelden zoals eerder beschreven als variabelen voor de hoogte van de transactiekosten. De elementen frequentie en asset specificiteit worden hierbij buiten beschouwing gelaten omdat voor bouwprojecten geldt dat ze een behoorlijke mate van uniciteit kennen en doorgaans een laagfrequent karakter hebben (je bouwt al snel voor minstens 30 jaar). Deze eigenschappen hebben wel invloed op transactiekosten, maar zijn per project meer een gegeven en niet beïnvloedbaar. Daar komt bij dat deze eigenschappen meer van belang zijn bij het vraagstuk een project via de hiërarchie ofwel via de markt te organiseren. Het antwoord op die vraag komt voor vrijwel elke opdrachtgever neer op het contracteren van marktpartijen. Dit vanwege het incidentele karakter van dergelijk projecten, het specialisme en kennis die ervoor nodig is, en het voor de meeste opdrachtgevers branche vreemde karakter (Williamson: type "C" projecten) van bouwprojecten ${ }^{40}$

Bijlage vi bevat daarnaast een overzicht van de effecten van de pips elementen op de productiekosten. Bijlage vi laat daarmee zien dat pips bijdraagt aan het minimaliseren van de som van de transactie- en productiekosten.

\subsection{NIE mechanismen en PiPs safeguards}

Behalve het leggen van een link tussen pips als methodiek en NIE, is ook per pips element ingezoomd op de mechanismen die leiden tot de effecten en de relatie gelegd met NIE inzichten. In deze paragraaf komen de zeven pips filters uit hoofdstuk twee aan de orde, aangevuld met twee werkzame elementen die niet opgenomen zijn bij de zeven filters zoals Kashiwagi ze presenteert. Deze aanvulling betreft het functioneel specificeren en het delen van de informatie omtrent het maximaal beschikbare budget. Waarom dat (ook) safeguards zijn wordt verderop behandeld.
${ }^{40}$ Zie hiervoor ook

Bijlage v met de

typologie van

projecten, waarbij

blijkt dat bouw-

projecten overwegend via de markt worden georganiseerd. 
${ }^{41}$ De fasering zoals hier weer gegeven wordt

door Kashiwag niet gehanteerd deze ordening wordt in dit onderzoek aangebracht omdat dit

de overzichtelijkheid bevordert Aanvankelijk onderscheidde men alleen de ex ante en ex post fase. De period of contact is daaraan toegevoegd. worden gehanteerd):

\section{Contactfase}

- Oplossingsvrij specificeren (Funcspec)

\section{Contractfase:} laten wegen (Qsleutelf); pips filter 3

\section{Control fase:}

Allereerst worden hieronder alle negen de werkzame pips elementen gesorteerd naar de contact-, contract- en controlfase ${ }^{41}$ (tussen haakjes worden de afkortingen weergegeven zoals die verderop in dit onderzoek

Maximaal beschikbaar budget vooraf mededelen (Budginf)

- Past performance informatie mee laten wegen (PPI); PiPs filter 1

- Risico's laten duiden en aan laten geven hoe men die denkt te managen; optimalisaties laten inbrengen (RAVA); pips filter 2

- Sleutelfunctionarissen interviewen en de resultaten daarvan mee

- Kwaliteit/prijs verhouding mee laten wegen ( $\mathrm{Pr} / \mathrm{kwal}) ;$ pips filter 4

- Risico's overdragen (Risktrans); pips filter 5

- Performance management o.b.v. harde data (Harddat); pips filter 6

- Performance rating na oplevering (PCR); pips filter 7

Onderstaand worden de bevindingen per pips element weergegeven.

\section{Oplossingsvrij specificeren}

Van functioneel specificeren wordt verwacht dat dit onzekerheid zal reduceren. Een aanbesteder die functioneel specificeert streeft niet langer na een 'waterdicht' bestek op te (laten) stellen, maar beperkt zich tot outputspecificaties. Het operationaliseren daarvan vormt juist de uitdaging voor de marktpartij die verantwoordelijk is voor een oplossing die voorziet in de gevraagde functionaliteiten. Omdat de marktpartij de oplossing zelf heeft ontwikkeld, zal hij daarmee meer commitment voelen hetgeen de neiging tot het vertonen van opportunistisch gedrag ontmoedigt. Functionele specificaties zijn doorgaans compacter, focussen op functionaliteiten. Op deze wijze

houdt dit element ook rekening met begrensde rationaliteit van actoren

\section{Invloed functioneel specificeren op:}

Consequenties van

Begrensde rationaliteit

Ontmoedigen opportu-

nistisch gedrag
Reduceren onzekerheid

Functionele specificaties zijn compact en focussen op benodigde functionaliteiten.

Functionele specificaties reduceren vraag onzekerheid.

Functionele specificaties ontmoedigen de neiging tot het vertonen van opportunistisch gedrag doordat de marktpartij zich zelf buigt over de (hoe) vraag; deze marktpartij voelt zich daar zelf verantwoordelijk voor.

Tabel 3.1; invloed van safeguard functioneel specificeren op NIE mechanismen

\section{Maximaal beschikbaar budget vooraf mededelen}

Het delen van informatie over het beschikbare budget speelt in op de begrensde rationaliteit. Het verheldert het kader waarbinnen een 'geldige' oplossing uitgewerkt dient te worden. Ook reduceert dit element onzekerheid; de kans op ongeldige inschrijvingen wordt immers gereduceerd. Wat het ontmoedigen van opportunistisch gedrag betreft, heeft dit element alleen indirect effect. Van meet af aan is duidelijk wat het werk maximaal mag kosten, dat ontmoedigt pogingen om kosten te verhogen. 


\section{Invloed informeren over maximaal budget op:}

Consequenties van

Begrensde rationaliteit

Reduceren onzekerheid

Ontmoedigen opportunistisch gedrag
Zorgt voor helder kader waarbinnen

oplossing moet passen

Verkleint kans op ongeldige inschrijving-

Ontmoedigt pogingen om kosten te verhogen.

Tabel 3.2; invloed van safeguard informeren over maximaal budget op NIE mechanismen

PPI

Past Performance Information (PPI) speelt bij pips een rol in de selectiefase. Gegadigden mogen conform de standaard Kashiwagi aanpak zelf van zoveel mogelijk van hun eerder gerealiseerde projecten PPI in-

brengen. De aan de aanbesteding deelnemende opdrachtnemer voert daar zelf de regie over, heeft de gelegenheid zich te onderscheiden en in te spelen op wat de nu aanbestedende opdrachtgever belangrijk vindt. De aanbestedende opdrachtgever kan en mag mate van relevantie mee laten wegen bij het toekennen van PPI scores. Deze scores wegen mee om tot de selectie van de meest aangewezen aanbieder te komen. Dit helpt om de aanbieder te selecteren die met een grote kans op succes het project tijdig, binnen budget, volgens kwaliteitsverwachting en in prettige samenwerking op kan leveren (Gruneberg, 2007). PPI draagt zodoende bij aan het vergroten van voorspelbaarheid en daarmee aan het verkleinen van onzekerheid en ook zal de neiging tot opportunistisch gedrag verkleind worden. Opdrachtnemers weten immers dat de performance tijdens een project de toekomstige scoringskansen kan beïnvloeden. Door PPI toe te passen aan de hand van een beperkt aantal feitelijke aspecten (op tijd, binnen budget en naar tevredenheid opgeleverd zijn de belangrijkste), helpt PPI ook om begrensde rationaliteit te compenseren en draagt het bij tot van verlaging van transactiekosten. Graham \& Chang (2007) zien echter een beperking in het 'reputatiemechanisme'. Ze stellen namelijk dat dit alleen reducerend werkt, voor wat betreft de neiging tot opportunisme, als derden voldoende zicht kunnen hebben op de vraag wie in welke mate gebruik (misbruik) heef gemaakt van wiens kwetsbaarheid. En juist die informatie is voor derden lastig toegankelijk en de betrouwbaarheid ervan is ook lastig vast te stellen. Een te laat opgeleverd project hoeft namelijk niet per definitie verwijtbaar te zijn aan de opdrachtnemer. Dat zelfde geldt voor budgetoverschrijdingen. Het is dus zaak bij het gebruiken van PPI voldoend aandacht te besteden aan validiteit en betrouwbaarheid van de past performance informatie ${ }^{42}$.

Het hanteren van PPI werkt bovendien zelfselectie in de hand ${ }^{43}$. Partijen die over te weinig bewezen (en dus past) performance beschikken, zulle eerder besluiten niet in te schrijven of zich snel terugtrekken. Dit reduceert transactiekosten en verhoogt de kans op selectie van een high performer. In het door ЕІв (2007) in opdracht van PSiBouw uitgevoerd onderzoek "Opdrachtgevers aan het woord" is de volgende passage te vinden die het meewegen van PPI onderschrijft:

"De meeste selectiecriteria, bedoeld om vooraf gekwalificeerde bedrijven tot de aanbesteding toe te laten, dragen achteraf niet bij tot meer tevredenheid over de prestaties van deze bedrijven. Uitzonderingen hierop: opdrachtgevers die als ervaringsgegeven, vooral selecteren op klantgerichtheid en betrouwbaarheid. Deze opdrachtgevers zijn beduidend meer tevreden dan opdrachtgevers die dat niet doen (pagina 15)."

pips richt zich met PPI op bewezen performance waarbij het nakomen van afspraken met betrekking tot kwaliteit, kosten en tijd centraal staat. Dit zijn belangrijke indicatoren voor de mate van betrouwbaarheid doen wat je zegt, binnen de afgesproken tijd en voor de afgesproken prijs. De belangrijkste invloed van PPI op de drie NIE mechanismen worden in het kader op de volgende pagina weergegeven. 


\section{Invloed PPI op:}

Consequenties van

begrensde rationaliteit

PPI info is compact en zoveel mogelijk feitelijk en countable. Dit reduceert marktonzekerheid als gevolg van informatie overload en/of misinterpretaties daarvan

Reduceren onzekerheid Alleen partijen die in het verleden goed gepresteerd hebben op algemeen erkende succescriteria blijven 'in de race', dit reduceert marktonzekerheid en verhoogt de voorspelbaarheid

Ontmoedigen opportunistisch gedrag

Het reputatiemechanisme zorgt ervoor dat marktpartijen de goede naam niet 'te grabbel willen gooien'; dit remt

transactieonzekerheid

Tabel 3.3; invloed safeguard PPI op NIE mechanismen

\section{Interviews}

Door sleutelfunctionarissen te interviewen en te beoordelen op hun competenties verklein je onzekerheid en indien er een fit is (met de job, het project, de mensen en de organisatie) is het gevaar van opportunistisch gedrag kleiner. In een goede relatie zul je immers minder snel besluiten nemen ten koste van de belangen van de ander, dan in een minder goede relatie. Daarnaast haal je sleutelfunctionarissen uit de anonimiteit en leren sleutelfunctionarissen van opdrachtgever en opdrachtnemer elkaar kennen (dit laatste laat onverlet dat er bij de project-start-up expliciet aandacht geschonken moet worden aan kennismaking en samenwerkingsafspraken). Ook dit zal bijdragen aan het beperken van neigingen tot opportunistisch gedrag. Williamson (1975) beschrijft dat de karakters van de beslissers die betrokken zijn bij de transactie van invloed zijn op de hoogte van de transactiekosten. TCE biedt dus legitimatie om bij deze interviews aandacht te besteden aan samenwerkingsbereidheid en vermogen.

Bij het beoordelen van de kwaliteit van sleutelfunctionarissen kan en mag de opdrachtgever zaken als samenwerkingscompetenties en sociaal communicatieve competenties meewegen ${ }^{44}$. Dit verkleint marktonzekerheid en transactieonzekerheid, reduceert de neiging tot opportunistisch gedrag waardoor transactiekosten lager uitvallen. Immers als communicatie soepel verloopt en samenwerkingsvaardigheden adequaa worden aangewend zal dit een soepele planning, afstemming, samenwerking, coördinatie en uitvoering van werkzaamheden bevorderen en daarmee transactiekosten (monitoring and bonding costs) verlagen. Door een team (in plaats van een enkel individu) de kwaliteit van sleutelfunctionarissen op vooraf bepaalde concrete criteria te laten beoordelen, objectiveer je het proces en houd je rekening met de begrensde rationaliteit van beoordelende individuen. Persoonlijke drive, ambitie, inzich en visie op het project kan bij het beoordelen van de kwaliteit van sleutelfunctionarissen eveneens doorklinken en meewegen. Dit vermindert onzekerheid, minder onzekerheid geeft minder aanleiding tot en kans op opportunistisch gedrag en daarmee lagere transactiekosten. Immers een goede 'vent' (vaak belangrijker dan de 'tent'!)

betekent meer vertrouwen, betekent lagere monitoring en bonding costs. Wanneer de kwaliteit van sleutelfunctionarissen meetelt bij de selectie zal de opdrachtnemer een betere kandidaat naar voren schuiven (concurrentie op kwaliteit sleutelfunctionarissen). Daardoor is er sprake van lagere faal- en herstelkosten, is minder controle nodig, is er sprake van betere communicatie en afstemming, kortom toename van vertrouwen (trust) en omgekeerd evenredige afname van transactiekosten.

Bovenstaande wordt tevens bevestigd door Waara (2008). In een onderzoek onder 15 Zweedse inkopers, toont hij aan dat sleutelfunctionarissen erg belangrijk zijn (thus it is the projectorganization that matters, and not the firm). De kwaliteit van de sleutelfunctionarissen wordt door hen dan ook als beoordelingscriterium gebruikt ${ }^{45}$. Daardoor wordt opportunistisch gedrag tijdens de bouw gereduceerd, zo blijkt uit dit onderzoek. De belangrijkste invloeden van het bij de selectie betrekken van de kwaliteit van sleutelfunctionarissen op de drie NIE mechanismen worden in het kader op de volgende pagina kort weergegeven.
${ }^{44}$ Het interviewen van sleutelfunctionarissen is alleen toegestaan als het belang (voor projectsucces) van de competenties waarover deze sleutelfunctionarissen dienen te beschik-

ken duidelijk uit alle aanbestedingsdocumenten blijkt; zie hoofdstuk zes voor meer info.

${ }^{45}$ Wel geven enkele inkopers aan dat vragen naar past performance van projectleiders could be biased. Meer hierover in hoofdstuk zes. 


\section{Invloed Kwaliteit sleutelfunctionarissen op:}

\section{Consequenties van Geobjectiveerde wijze van interviewen}

begrensde rationaliteit draagt bij aan faire vergelijking van com-

petenties, reduceert daardoor marktonze-

kerheid.

Reduceren onzekerheid Meewegen van visie, inzicht, samenwer-

kingsvermogen en projectmanagement

kwaliteiten reduceert markt- en trans-

actieonzekerheid in hoge mate.

Ontmoedigen opportu- Doet appèl op reputatiemechanisme en nistisch gedrag haalt mensen uit anonimiteit; dit verklein transactieonzekerheid.

Tabel 3.4; invloed safeguard kwaliteit sleutelfunctionarissen op NIE mechanismen

\section{RAP/RAVA}

${ }^{46} \mathrm{RAP}$ is in de loop der jaren door Kashiwagi omgedoopt in RAVA (Risk Assessment Value Added) pips laat inschrijvers een Risk Assessment Plan (RAP/RAVA) ${ }^{46}$ maken.

Daarin identificeren en prioriteren ze de in hun ogen belangrijke projectrisico's. Ook geven ze aan hoe ze de geidentificeerde risico's denken te managen. Naast het feit dat dit informatief is voor de opdrachtgever, en hij de kwaliteit van deze plannen mag laten meewegen bij de gunning, reduceert dit ook project onzekerheid. Rahman \& Kumaraswamy (2002):

"a clear definition of the risks and their proper allocation provides incentives for the efficient management of risks during the construction process" (pagina 45).

Het zal voor een low performer een zware opgave zijn een RAP/RAVA op te stellen dat hoger scoort dan dat van een high performer. Het

RAP/RAVA filter draagt dus bij aan het selecteren van de meest gerede partij en daarmee aan het reduceren van onzekerheid. Ook zal het hanteren en meewegen van een RAP/RAVA zelfselectie bevorderen en daarmee transactiekosten verlagen. De belangrijkste invloeden van het bij de selectie betrekken van de kwaliteit van RAP/RAVA's op de drie NIE mechanismen worden in onderstaand kader weergegeven.

\section{Invloed RAP/RAVA op:}

Consequenties van

begrensde rationaliteit

Ruceren onzekerheid

Ontmoedigen opportunistisch gedrag
RAP/RAVA is compact en zoveel mogelijk feitelijk; daardoor houdt pips rekening met begrensde rationaliteit van actoren waardoor onzekerheid wordt gereduceerd.

RAP/RAVA separeert high performers van low performers. Tijdige aandacht voor riskmanagement vertaalt zich in minder markt- en transactieonzekerheid

Het "reputatiemechanisme" zorgt ervoor dat marktpartijen de in het RAP/RAVA geschetste verwachtingen waar willen maken en reduceert daarmee transactieonzekerheid.

Tabel 3.5; invloed van safeguard RAP/RAVA op NIE mechanismen

\section{Prijs/kwaliteit}

pips selecteert op kwaliteit én prijs. Aanbieders kunnen zich daardoor onderscheiden op kwaliteit en niet alleen door laagste prijs. Daardoor wordt, zoals al eerder betoogd voorkomen dat de marge van aanbieder te zeer onder druk komt te staan wat de neiging tot opportunistisch 
gedrag zou bevorderen. De kwaliteitsfocus zal (in combinatie met een vraagspecificatie die een zekere mate van oplossingsvrijheid kent) voorts tot gevolg hebben dat de kans op het selecteren van een competente partij groter wordt. Dat zal de kans op projectsucces ten goede komen. Aanbieders kunnen een redelijke marge maken doordat prijs voor bijvoorbeeld 30\% meetelt en kwaliteit voor $70 \%$. Dit verkleint de neiging tot opportunistisch gedrag. Bij traditionele aanbestedingen zoeken opdrachtnemers vaak 'gaten in het bestek' om meerwerk te kunnen declareren om daarmee toch nog tot een bevredigend financieel resultaat te komen. Door prijs èn kwaliteit mee te laten wegen, verkleint pips dus het gevaar van deze bedreiging van projectsucces die in de literatuur bekend staat onder de term moral hazard (Williamson, 1975). pips is niet eendimensionaal (zoals traditioneel; alleen prijsfocus). Daarmee voorkom je problemen in projectbeheersing als gevolg van het feit dat opdrachtnemers opportunistisch gedrag vertonen om, desnoods ten koste van de opdrachtgever, toch een redelijk resultaat te kunnen boeken. Minder bonding en monitoring costs zijn hiervan het gevolg, er zijn namelijk minder maatregelen nodig om opportunisme te voorkomen en/of de mogelijke gevolgen ervan af te zwakken.

Vergelijkbaarheid en beoordeling van inschrijvingen worden echter lastiger doordat selectie op kwaliteit een prominente plaats inneemt. Inschrijfprijzen zijn goed vergelijkbaar, bij kwaliteit is dat complexer. Dat stelt extra eisen aan het operationaliseren van ' $k w a l i t e i t$ '. Dit brengt in eerste instantie een verhogend effect op transactiekosten met zich mee. Wanneer die operationalisaties (maatstaven en normen) eenmaal beschikbaar zijn, wordt meten en sturen op kwaliteit juist weer eenvoudiger en efficiënter.

Doordat het onderscheidende vermogen voor een groot deel bepaald wordt door kwaliteit, zal bij een pips aanbesteding zelfselectie plaatsvinden. Contractors die weten dat ze een geringere kans zullen maken dit project te scoren vanwege die kwaliteitsfocus, zullen niet meedingen of zich eerder terugtrekken. Dat reduceert onzekerheid en verlaagt transactiekosten. De belangrijkste invloeden van het bij de selectie betrekken van de kwaliteit/prijs verhouding op de drie NIE mechanismen worden in het kader op de volgende pagina weergegeven.

\section{Invloed Prijs/Kwaliteit op:}

Consequenties van

begrensde rationaliteit

Reduceren onzekerheid nistisch gedrag
Vergelijking vraagt om groter vermogen om ingebrachte plannen en aanpakken te kunnen vergeliiken. Als 'kwaliteit' werkbaar geoperationaliseerd is geeft dat juist meer houvast.

Kwaliteitsfocus triggert onderscheiden vermogen op kwalitatief gebied. Zelfselectie verkleint de kans op incompetente deelnemers. Daardoor wordt de marktonzekerheid gereduceerd.

Als aannemers zich verzekerd weten van de mogelijkheid bij professionele bedrijfsvoering een redelijke marge te kunnen maken, vervalt de neiging tot opportunistisch gedrag en kan alle energie letter lijk en figuurlijk constructief aangewend worden. Dat verkleint transactieonzekerheid.
Tabel 3.6; invloed van safeguard prijs/kwaliteit op NIE mechanismen

(Pre) award

Bij dit pre-award filter wordt ook het pips element risk transfer

besproken.

Tijdens de pre-award fase bespreken opdrachtgever en opdrachtnemer de laatste details, werken de planning gedetailleerd uit en overleggen over precieze demarcatielijnen ten aanzien van taken, verantwoordelijkheden, bevoegdheden en risico's. De opdrachtnemer 'pakt' het project pas als alle aspecten helder en voor hem acceptabel zijn. De opdrachtnemer heeft tevens de taak in deze fase inzichtelijk en aannemelijk te 
maken dat zijn oplossing een passend en dekkend antwoord vormt op de vraag die de opdrachtgever heeft gesteld. Er is dus geen sprake van het rücksichtslos 'over de schutting werpen' van risico's, een en ander gebeurt in samenspraak; er is sprake van risico overdracht op basis van consensus. Dit reduceert onzekerheid. Ook ontstaat daardoor alignment of goals, wat zoals hiervoor ook al aangegeven een verlagende invloed heeft op transactiekosten. Deze pre-award fase zorgt ook voor het verkleinen van informatieasymmetrie.

Dorée (2001) maakt melding van verstarring die in de bouw optreedt wanneer onzekerheden dominant aanwezig zijn. Deze verstarring is in principe ongewenst, omdat juist flexibilisering een betere propositie is in tijden van onzekerheid. Dorée verklaart deze verstarring vanuit de gewoonte in de bouw om verhoudingen contractueel vast te leggen en daarbij 'alles te willen dichttimmeren' (om daarmee te vermijden voor kosten van onvoorziene zaken te moeten opdraaien). Doordat pips in de pre-award fase juist op basis van consensus komt tot risico transfer, en doordat pips contracten idealiter meer kenmerken van relationale contracten vertonen dan van klassieke contracten, draagt pips bij aan het reduceren van deze verstarring en daarmee aan het reduceren van onzekerheid.

pips draagt bij gunning een aantal risico's over aan de opdrachtnemer. Deze heeft er dus belang bij deze risico's adequaat te managen. Volgens de property rights theorie, zal de opdrachtnemer zich dankzij deze eigendomspositie inzetten om de risico's goed te beheersen. Veranderingen in eigendomspositie zullen leiden tot veranderingen in gedrag doordat individuen zelf de vruchten van dat andere gedrag kunnen plukken (Williamson, 1985).

Tijdens de pre-award fase wordt een en ander contractueel vastgelegd. Het contract bestaat uit documenten uit eerdere fasen/filters en uit een omschrijving van te behalen resultaten (output omschrijving), fixed price en risicoverdeling zoals tijdens de pre-award fase overeengekomen. In een traditionele setting worden zoveel mogelijk contingenties voorzien en worden ze contractueel vastgelegd. Omdat er rekening gehouden dient te worden met marktimperfecties, niet alles is te voorzien en mensen beperkt rationeel zijn, blijken deze contracten nooit 100\% waterdicht te zijn (Dorée, 2001; Speklé, 2001; Stomp, 2004; Dorée \& Boes, 2007). Pips stuurt aan op een accountable opdrachtnemer, die at risk is en overeengekomen output levert, tegen overeengekomen kosten. Omdat de opdrachtnemer zelf de technische uitwerking van de gevraagde functionaliteiten heeft gemaakt, kan hij zich niet 'verschuilen achter' het bestek van de opdrachtgever. Dit dringt de neiging tot opportunistisch gedrag terug, verkleint onzekerheid en hoge transactiekosten ten gevolge van lijvige contracten worden voorkomen. In plaats van het zoeken van zekerheid in contracten, werkt het op PPI gebaseerde reputatiemechanisme als een impliciete belofte voor een redelijke en eerlijke oplossing voor een probleem waarin het contract niet voorziet (Dorée, 2006). Een pips contract vertoont dan ook meer overeenkomsten met het neo klassieke contractmodel volgens Williamson, waarin safeguards zijn opgenomen. Neo klassieke contracten verlagen de transactiekosten t.o.v. klassiek contracten. Rahman \& Kumaraswamy (2002) noemen dit Relational Contracting. Ze stellen dat relational contracting leidt tot reductie van transactiekosten, de samenwerking verbetert en teamwork bevordert:

"Relational Contracting offers a cost effective means of enforcing good (but apparently unprofitable) behaviour when transactions are associated with exposure to opportunism, but a fully contingent contract is too costly (if not impossible) to specify." (pagina 48)

Ze beschrijven ook de 'onmogelijkheid' om een 100\% waterdicht contract af te sluiten en de kostenverhogende effecten van pogingen daartoe. De belangrijkste invloeden van de pre-award fase op de drie NIE mechanismen worden het kader op de volgende pagina weergegeven. 


\section{Invloed (Pre) award op:}

Consequenties van

begrensde rationaliteit

Heldere en geaccepteerde demarcatie van focussen op risico's waar zij verantwoordelijkheid voor dragen. Dit reduceert transactieonzekerheid.

Reduceren onzekerheid Adequate verdeling van risico's en sluitende afspraken daarover in combinatie met ownership effecten reduceren transactieonzekerheid.

Ontmoedigen opportunistisch gedrag risico's maakt dat actoren zich kunnen
Het overdragen van risico's bevordert het verantwoordelijkheidsgevoel (ownership matters) en reduceert daarmee transactieonzekerheid.
Tabel 3.7; invloed van safeguard pre-award fase op NIE mechanismen

\section{Post Construction Rating (PCR)}

Tijdens de behandeling van dit pips filter wordt zowel Harddat als PCR besproken.

De combinatie van de uitvraag aan de hand van een functionele (oplossingsvrij gespecificeerde) vraagstelling, de fixed price en de overdracht van risico's, maakt dat de opdrachtnemer wel efficiënt moet werken. Er is immers alleen ruimte voor meerwerk dat door de opdrachtgever zelf is geïnitieerd. Binnen de gecontracteerde projectscope realiseert de aannemer de oplossing waaraan hij zelf heeft bijgedragen voor een vaste prijs; hoe efficiënter hij dit doet, des te groter zijn marge. Daarnaast realiseert hij zich dat het reputatiemechanisme gehanteerd wordt, dus eventuele 'verleidingen' om het met de kwaliteit minder nauw te nemen zal hij weerstaan. Deze efficiency drive zal faal- en herstelkosten verlagen (de dingen in een keer goed doen is immers ook in opdrachtnemer's belang!) en inzet van slimme oplossingen, adequaat geschoold personeel evenals goede communicatie bevorderen waardoor de transactiekosten lager uitpakken dan bij de traditionele setting

(Goddard \& Mannion, 1998; Cheung et al, 2005; Kadefors, 2005;

Dagenais, 2007). Het gebruik van PPI maakt dat de opgebouwde, maar nu ook onderbouwde reputatie (dus niet alleen op grond van de eigen glossy folders, of het benoemen van referentieprojecten zonder performance data) een impliciete belofte voor een goede oplossing is (Dorée, 2006). De opdrachtnemer zal die belofte in willen lossen (wil zijn reputatie niet 'te grabbel gooien', want dat verkleint de scoringskans bij volgende aanbestedingen) wat opportunistisch gedrag afremt (Guccio et al 2008). Ook wordt onzekerheid daardoor verkleind (Williamson, 1985; Jin \& Ling, 2005)

Tijdens de uitvoering van het project wordt 'harde' performance data gebruikt. De opdrachtnemer meet zijn eigen performance, en rapportee wekelijks daarover ${ }^{47}$. Dit gebeurt gekwantificeerd en voor enkele (een zeer beperkt aantal) meetbare indicatoren (Kashiwagi, 2004). Dat help om begrensde rationaliteit te compenseren. Deze efficiënte rapportagewijze verlaagt transactiekosten.

Dankzij PPI, Risk Assessment Plan, Interview en het bespreken van risico's tijdens pre-award fase is het vertrouwen in de opdrachtnemer gegroeid. Tijdens de uitvoering van het project zal de behoefte van de opdrachtgever om de opdrachtnemer te controleren dan ook minder manifest zijn ${ }^{48}$. Dit brengt lagere monitoring en bonding costs met zich mee. Ook is de behoefte aan safeguards in het contract daardoor lager. Ook dit vertaalt zich in lagere controle-, inspectie-, arbitrage- en problemshooting/solving costs. Kortom residual costs (zie Bijlage v) zullen lager uitpakken.

PiPs voorziet in een post construction rating. Daarmee biedt pips een OPH (Over de Projecten Heen) mechanisme, wat opportunistisch gedrag ontmoedigt (Axelrod, 1994; Bresnen, 2000; Graafland, 2007). De

performance op dit project, werpt daardoor haar schaduw vooruit wat zich vertaalt in betere of slechtere kansen op toekomstig werk. Dit blijkt een effectief mechanisme te zijn dat tot positieve effecten leidt met betrekking tot projectsucces (Dorée, 1996, 2001). Post Construction Rating (PCR) bevordert de motivatie van de opdrachtnemer om taken zodanig uit te voeren dat de doelstellingen van de opdrachtgever worden
${ }^{47}$ Deze werkwijze vertoont parallellen met de zogenoemde vendor rating aanpak waarbij de prestatieniveau's van marktpartijen en gecontracteerde leveranciers ook

kwantitatief worden gevolgd waardoor inzicht in performance ranking ontstaat.

${ }^{48}$ Zoals in hoofdstuk 3 is te lezen, bedraagt de reductie van management inspanning aan opdrachtgeverszijde dan ook tientallen procenten. 
behaald op aanvaardbare wijze. Hogere motivatie bij opdrachtnemer, verlaagt transactiekosten. De belangrijkste invloeden van PCR op de drie NIE mechanismen worden in onderstaand kader weergegeven.

\section{Invloed (Post) Construction fase op:}

Consequenties van

begrensde rationaliteit

\section{Reduceren onzekerheid}

Opdrachtgever vertaalt gerealiseerde

performance van opdrachtnemer in één

score; deze informatie is eenvoudig te

interpreteren en te verwerken.

De gecontracteerde partij zal vanwege reputatiemechanisme en kansen op toe-

komstig werk high performance waa

willen maken. Is ook vanwege risico

verdeling in zijn belang. Beide zaken

reduceren transactieonzekerheid.

Ontmoedigen opportu- Opportunistisch gedrag past niet in een

nistisch gedrag setting waarin belangen van opdracht-

gever en opdrachtnemer in elkaars

verlengde liggen waarbij de opdracht-

nemer zich realiseert dat de kwaliteit

van vandaag de kansen voor morgen

mede bepaalt. Daardoor wordt transactie-

onzekerheid gereduceerd.

Tabel 3.8; invloed van safeguard PCR op NIE mechanismen
3.7.2 PiPs elementen en safeguards

Vervolgens wordt ingegaan op de stap van pips element naar safeguard. Een safeguard is volgens Williamson ${ }^{49}$ : Een mechanisme om de kans op opportunistisch gedrag van de aannemer ex post contract ${ }^{50}$ te verkleinen (Dorée, 1996,). Safeguards zijn volgens Williamson in drie categorieën te verdelen (zie ook hoofdstuk vier):

$n r 1$ Belonings- en straf procedures;

\section{nr 2 Conflictregulering;}

nr 3 Continuïteitsondersteunende mechanismen;

49 De belangrijkste auteur (en Nobelprijswinnaar Economie 2009) op het gebied van NIE in het algemeen en TCE in het bijzonder.

${ }^{50} \mathrm{Na}$ gunning van de opdracht.

In onderstaande tabel worden de pips elementen gerubriceerd naar de drie soorten Safeguards zoals Williamson die onderscheidt.

\section{Belonen/straffen Conflictregulering Continuiteitsonderst.}

Funcspec

Budginf

PPI

RAVA

Qsleutelf

$\operatorname{Pr} / \mathrm{kwal}$

Risktrans

Harddat

PCR
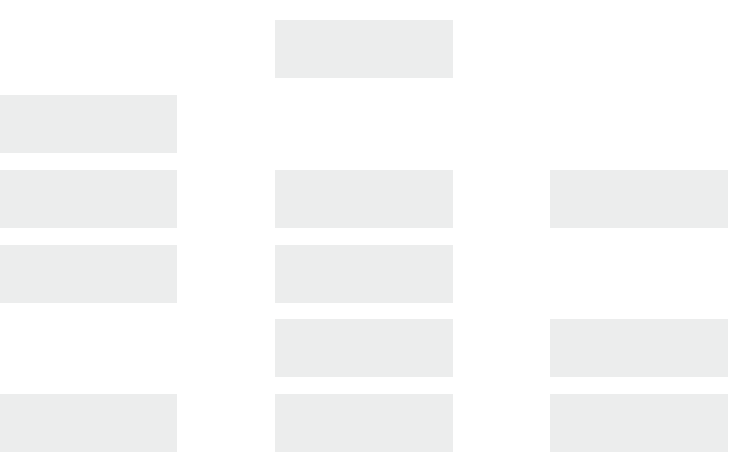

Tabel 3.9; Pips elementen gesorteerd naar soorten Safeguards volgens Williamson 
Hieronder wordt toegelicht waarom de achtereenvolgende pips elementen als safeguard kunnen worden beschouwd.

Inschrijvers uitdagen door middel van het hanteren van een oplossingvrije specificatie (Funcspec) is een safeguard die met name bijdraagt aan conflictregulering (voorkomt het verschuilen achter oplossingen van anderen). Voor hun eigen inbreng zullen aannemers zich meer verantwoordelijk voelen (ervan uitgaande dat de risico's die met deze inbreng samenhangen ook overgedragen worden aan deze aannemer). Opdrachtgevers zullen minder onzeker zijn over de geformuleerde vraag want door gewenste output te beschrijven in plaats van 'alles' uit te werken wat nodig is om tot die gewenste functionaliteiten te komen, is het risico van een incompleet bestek geringer en treden minder fricties op over de 'letter en de geest' van de overeenkomst.

Informatie over het maximaal aan te wenden budget van meet af aan delen met marktpartijen (budginf) is een safeguard die vooral gericht is op belonen/straffen. Weten wat het budgetplafond is van de opdrachtgever en tegelijkertijd weten welke functionaliteiten deze opdrachtgever gerealiseerd wil zien, bevordert win kansen van high performers.

PPI gebruiken (PPI) is een safeguard want de aannemer weet en beseft dat de performance die hij op dit project tentoonspreidt, zijn kansen op toekomstig werk mede beïnvloedt (gericht op belonen/straffen en tegelijkertijd continuiteitsondersteunend). Graafland en Nijhof (2007) noemen dit het reputatiemechanisme. Opportunistisch gedrag draagt niet bij tot het verstevigen van een reputatie (dus ook gericht op conflictregulering).

Kwaliteit van Risk Assessment Plan/Value Added (RAVA) mee laten wegen is een safeguard die gericht is op belonen/straffen (een goed RAVA verhoogt win kansen). Daarnaast is deze safeguard gericht op conflictregulering. Dit wordt veroorzaakt door de door de leverancier in te brengen optimalisaties; die zal hij tot een succes willen maken.

Kwaliteit sleutelfunctionaris meewegen (Qsleutelf) is een safeguard die gericht is op conflictregulering, want samenwerkingsvermogen gerelateerd aan wat het nu aan te besteden werk vraagt, vormt een van de speerpunten van deze safeguard. Deze safeguard stelt de opdrachtgever in de gelegenheid (proportionele!) eisen te stellen aan persoonlijkheid, integriteit en competenties (ook op het gebied van bouwprocesmanagement en samenwerken) waardoor de kans groter wordt dat competenties van sleutelfunctionarissen aansluiten bij wat het aan te besteden werkt vraagt. Voor opdrachtnemers betekent dit dat het hebben en houden van 'goede mensen' zijn kansen op het winnen van aanbestedingen vergroot (contuïnuiteitsondersteunend).

Focus op kosten én kwaliteit $(\mathrm{Pr} / \mathrm{kwal})$ is een safeguard die vooral is gericht op conflictregulering. Gunnen op waarde voorkomt namelijk dat de laagste-prijs-klem wordt gehanteerd. Het vertonen van opportunistisch gedrag is daardoor minder 'nodig' om een faire marge te kunnen maken. Deze safeguard is tevens gericht op belonen/straffen, doordat de kwaliteit van de oplossing van invloed is op win kansen. Toepassing van deze safeguard leidt tot meer tevredenheid aan de zijde van opdrachtgever en opdrachtnemer en is daardoor ook gericht op continuïteitsondersteuning.

Risico's, op basis van in de pre award fase gemaakte afspraken, leggen bij die partij die deze het beste kan managen (Risktrans) is een safeguard die is gericht op conflictregulering. Risico overdracht schept duidelijkheid over de vraag wie at risk is; daardoor worden veel conflicten vermeden.

Performance management op basis van harde data (Harddat) is een safeguard die bijdraagt aan conflictregulering doordat er objectieve en feitelijke performance data beschikbaar is. Vanuit deze performance data is de link naar bonussen en/of penalties snel gelegd; deze safeguard is ook gericht op belonen/straffen.

Performance rating na oplevering (PCR) is een safeguard die gericht is op belonen/straffen (voorsprong/achterstand bij aanvang nieuwe aanbesteding) en draagt ook bij aan continuïteitsbevordering (goede performance op huidige project vergroot de kans dat deze aannemer een volgend project wint). 
$\mathrm{Nu}$ helder is dat en waarom de pips elementen als safeguards zijn te beschouwen, wordt stilgestaan bij de vraag hoe deze safeguards in de praktijk bijdragen aan het reduceren van onzekerheid en de neiging tot opportunistisch gedrag. Om deze vraag te kunnen beantwoorden worden in hoofdstuk zes een aantal operationalisaties van onzekerheid en opportunistisch gedrag geformuleerd. Vervolgens wordt onderzocht of er relaties te leggen zijn tussen deze operationalisaties en de safeguards. Deze zogeheten confrontaties verduidelijken welke effecten (ten aanzien van het reduceren van onzekerheid en het ontmoedigen van de neiging tot opportunistisch gedrag) we vooronderstellen bij toepassen van de safeguards. In Bijlage viI wordt in vier tabellen weergegeven welke van deze relaties in het kwantitatieve onderzoek in hoofdstuk zes worden onderzocht.

\subsection{Deelconclusies over de werking van PiPs}

Zoals in dit hoofdstuk aangegeven functioneren de pips elementen als safeguards (zie NIE theorie in Bijlage v). Toepassing van deze safeguards reduceert onzekerheid, verkleint de ruimte voor en neiging tot het vertonen van opportunistisch gedrag na gunning en reduceert de consequenties van begrensde rationaliteit. Omdat deze laatste factor, begrensde rationaliteit, zich vertaalt in het nemen van beslissingen (op basis van ervaring of op basis van een deel van de beschikbare informatie en/of op basis van gebrekkige interpretatie/benutting van beschikbare informatie) in plaats van de relevante beschikbare informatie snel en goed te verwerken en 'voor zich te laten spreken', manifesteert begrensde rationaliteit zich in meer onzekerheid. Vandaar dat verderop in het kwantitatieve onderzoek (hoofdstuk zes) enkel gesproken wordt over het reduceren van onzekerheid (waarin de effecten op het beperken van de consequenties van begrensde rationaliteit mee genomen worden) en het ontmoedigen van de ruimte voor en neiging tot opportunisme. Geringere onzekerheid en ontmoedigd opportunistisch gedrag dragen bij aan projectsucces. Onzekerheid en opportunisme kunnen zowel bij opdrachtgever als opdrachtnemer een rol spelen tijdens de aanbesteding en tijdens de samenwerking. Behalve aan het reduceren van onzekerheid en het ontmoedigen van opportunistisch gedrag leidt toepassing van pips elementen ook tot andere effecten zoals een efficiënter proces, lagere transactiekosten, professionalisering van de sector en grotere tevredenheid over het eindresultaat. Bovendien zijn er de invloeden van factoren die buiten de pips aanpak liggen (denk aan weer, markt ondergrond etc). Deze rechtstreekse effecten worden in onderstaan model weergegeven door middel van de pijl die rechtstreeks loopt van de "overige factoren" naar "projectsucces". In schema:

\section{Overige}

factoren

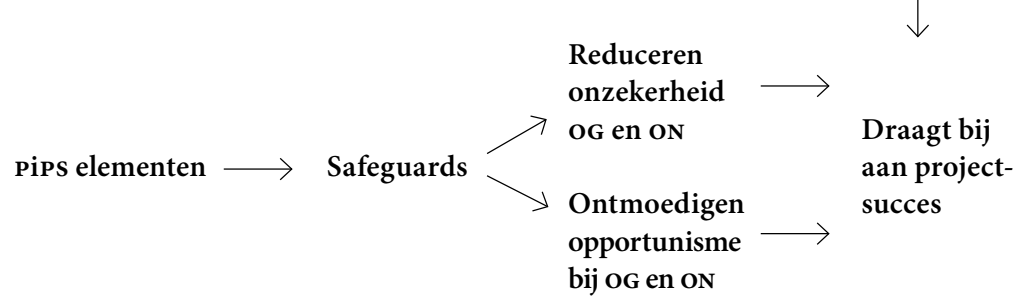

Afbeelding 3.2; Schematische weergave theoretisch model

In hoofdstuk zes zal dit model de 'kapstok' vormen voor het kwantitatieve onderzoek waarmee de in dit huidige hoofdstuk behandelde theoretische redeneringen aan een toetsend onderzoek worden onderworpen.

Het koppelen van de NIE inzichten aan de pips methodiek levert behalve het hiervoor gepresenteerde model de volgende deelconclusies op (gevolgd door een korte toelichting/motivering): 
Deelconclusie $\mathbf{3 . 1}$

DE RATIO ACHTER DE PIPS EFFECTEN WORDT VOORAL

GEVORMD DOOR DE ECONOMISCHE MECHANISMEN DIE IN NIE BESCHREVEN ZIJN.

De effecten die toepassing van pips oplevert zijn voor het overgrote deel te herkennen in termen van ander, cooperatiever, gedrag. Ander gedrag wordt veroorzaakt door economische mechanismen (onder andere: weten dat je in de gelegenheid zult zijn een faire marge te maken doordat kwaliteit zwaarder weegt dan laagste prijs, triggert gedrag dat gericht is op het realiseren van die kwaliteit. Immers het reputatiemechanisme verlangt het realiseren van kwaliteit als voorwaarde om de kansen op toekomstig werk te vergroten).

Deelconclusie $\mathbf{3 . 2}$

PIPS REDUCEERT ONZEKERHEID EN VERLAAGT DE NEIGING TOT OPPORTUNISTISCH GEDRAG NA GUNNING.

Er is meer informatie beschikbaar waardoor de voorspellende waarde van de aanbesteding wordt vergroot. Bij een pips project 'ontbreken' de motieven voor opportunistisch gedrag na gunning.

\section{Deelconclusie 3.3}

PIPS ELEMENTEN FUNCTIONEREN ALS SAFEGUARDS EN DRAGEN DAARDOOR BIJ AAN PROJECTSUCCES.

Safeguards reduceren onzekerheid en ontmoedigen de neiging tot het vertonen van opportunistisch gedrag; daardoor dragen ze bij aan projectsucces.

Het is nu bekend hoe de pips methodiek in elkaar zit, dat de methodiek in de Verenigde Staten van Amerika tot opmerkelijke resultaten leidt en er is een bevredigende verklaring (met behulp van NIE inzichten) voor de werking van de methodiek beschikbaar. Als vanzelf rijst nu de vraag hoe pips inpasbaar is binnen het geldende regime van het (Europese) aanbesteden zoals dat hier geldt. Hieraan wordt aandach besteed in het volgende hoofdstuk (vier). Daarna wordt in hoofdstuk vijf in gegaan op de ervaringen die het toepassen van pips elementen bij enkele praktijkcases in Nederland die in het kader van dit onderzoek zijn uitgevoerd heeft opgeleverd. 


\section{pips en het in}

\section{Nederland geldende}

juridische kader

pips blijkt in de Verenigde Staten van Amerika effectief te zijn en er is vanuit NIE een meer bevredigende verklaring voor de werking van de methodiek voorhanden. Om echter defacto een bijdrage te kunnen leveren aan de door de Nederlandse bouwsector beoogde veranderingen, is onderzoek naar de toepasbaarheid van de pips elementen vanuit juridische optiek nodig. Een belangrijke voorwaarde voor de implementatie van 'PiPS wise-aanbestedingen' is gelegen in het antwoord op de vraag of en vooral hoe aanbestedende diensten die gehouden zijn aan het wettelijke kader (In Nederland gevormd door het BAO: Besluit Aanbestedingsregels Overheidsopdrachten ${ }^{51}$ ) de verschillende pips elementen toe kunnen passen volgens en binnen dat kader. In de praktijk zien we in toenemende mate dat aanbestedende diensten elementen van de pips methodiek toepassen. De vraag of alle pips elementen toepasbaar zijn, is daarmee nog niet beantwoord. Vandaar dat in dit hoofdstuk nagegaan wordt over welke elementen nog discussie gevoerd wordt 
en over welke elementen helderheid bestaat met betrekking tot de vraag of toepassing van dit element door een aanbestedende dienst wel of geen fricties met het juridisch kader kent.

Om het antwoord op deze laatste vraag te vinden is in eerste instantie de primaire bron, de wetstekst bestudeerd en ook de daarop gebaseerde "Leidraad aanbesteden Bouwopdrachten 2009" (hierna "de Leidraad").

Als leidend principe voor die bestudering zijn de door de opdrachtgever te maken keuzes bij de inrichting van het aanbestedingsproces, gehanteerd. Het belang van die keuzes wordt in verschillende onderzoeken bevestigd (Lee, 2001; Zhang et al, 2003)

De onderzoeksbevindingen die bestudering van de hierboven genoemde bronnen opleveren zijn ter toetsing vergeleken met de resultaten van een interviewronde langs de in 2006 geconsulteerde in aanbestedingsrecht gespecialiseerde juristen.

Naast deze meer theoretische verkenning heeft tijdens de aanbesteding van de aanleg van het bergbezinkbassin (2009) voor de gemeente

's-Hertogenbosch een juridische check plaatsgevonden die vanuit deze praktijkcase de juridische risico's in beeld brengt die het toepassen van pips elementen met zich mee kan brengen (zijn de pips elementen vanuit juridische optiek toepasbaar?). De inzichten van het theoretisch onderzoek in combinatie met de inzichten uit deze praktijkcase hebben geleid tot het ontwikkelen van een procesmodel in twee varianten waarbij de pips elementen een plaats krijgen, gebaseerd op de niet openbare procedure (hoe kan aan die toepasbaarheid invulling gegeven worden?). De niet openbare procedure is gekozen omdat deze veelvuldig gehanteerd wordt binnen de sector. Het hanteren van deze procedure draagt immers bij aan het reduceren van transactiekosten (Constantino et al, 2008) en stelt de opdrachtgever in staat van meet af aan het aantal marktpartijen tot een hanteerbaar en proportioneel aantal te beperken. Aan het einde van dit hoofdstuk worden deelconclusies geformuleerd met betrekking tot de binnen het juridische kader aanwezige toepassingsmogelijkheden van de pips elementen.

\subsection{Het in Nederland geldende juridische kader}

In het Staatsblad van het Koninkrijk der Nederlanden, nummer 408, is het besluit d.d. 16 juli 2005, houdende regels betreffende de procedure voor het gunnen van overheidsopdrachten voor werken, leveringen en diensten gepubliceerd onder de titel Besluit Aanbestedingsregels voo Overheidsopdrachten (kortweg en hierna BAO). Het BAO vormt de Nederlandse concretisering van de Europese wetgeving hieromtrent (Richtlijn 2004/18/EG)

Als eerste wordt hier kort ingegaan op de hoofdlijnen van het hierboven geintroduceerde BAO. Het BAO schetst de regels waar aanbestedend diensten ${ }^{52}$ zich aan te houden hebben bij het zogehete Europese aanbesteden

Paragraaf 7 gaat in op o.a. technische specificaties ${ }^{53}$, en draagt ook deze titel hoewel het BAO ook functionele specificaties toestaat.

Paragraaf 8 beschrijft de verschillende procedures en hun toepassingsbereik. Voor een beschrijving van de verschillende aanbestedingsprocedures zie bijlage viII. Paragraaf 9 behandelt de manier van aankondigen en paragraaf 10 gaat in op de te respecteren termijnen. Paragraaf 11 gaat in op informatieverstrekking van aanbestedende dienst naar deelnemers. Paragraaf 12 biedt de meeste houvast voor dit onderzoek en gaat in op uitsluiting, selectie en gunning. Hierop wordt in de loop van dit hoofdstuk uitgebreid terug gekomen. Daarna volgen nog enkele paragrafen over elektronisch veilen, concessieovereenkomsten en enkele afrondende paragrafen.

Om de juridische ruimte voor het toepassen van pips elementen in beeld te brengen, worden in deze paragraaf de beslissingen gevolgd die een aanbesteder te nemen heeft in het kader van een concrete aanbesteding. Naast de centraal staande vraagstelling met betrekking tot rechtmatig heid worden ook enkele opmerkingen gemaakt met betrekking to

doelmatigheid waar dat zinvol wordt geacht. Waar dit van toepassing is wordt de motivatie daartoe in de tekst opgenomen.

Achtereenvolgens worden in deze paragraaf beslissingen behandeld ten aanzien van:
${ }^{52}$ Artikel 1 van BAO gaat in op het fenomeen 'aanbestedende dienst'. Populair gezegd zijn dit organisaties die een publiek belang dienen en/of voor het merendeel met publieke middelen zijn gefinancierd. Dat dit niet altijd eenduidig is te interpreteren blijkt uit al jaren voortslepende procedures omtrent het al dan niet aanbestedingsplichtig zijn van (academische) ziekenhuizen (zie o.a. Amphia arrest)

${ }^{53}$ Dat het BAO artikel 7 de naam "technische specificaties" draagt, is een voortvloeisel uit de Franse invloeden zoals die in de geschiedenis speelden. Franse opdrachtgevers zwoeren bij stipt uitgewerkte technische specificaties (mondelinge adstructie van Chris Jansen tijdens bespreking van dit hoofdstuk op 12 april 2011 te Amsterdam) 

A De bouworganisatievorm
B De vraagspecificatie
C De contractvorm
D De aanbestedingsprocedure
E Uitsluitingsgronden, kwalitatieve geschiktheidseisen en selectiecriteria
F Het gunningscriterium en
G Het uitwisselen van informatie.

\section{A Beslissingen t.a.v. de bouworganisatievorm}

\section{Introductie}

de aanbesteder zal een beslissing moeten nemen over de bouworgani-

${ }^{54}$ De wijze waarop de in een bouwproces uit te voeren taken in het concrete geval over de verschillende deelnemers aan het bouwproces zijn verdeeld. satievorm ${ }^{54}$ die hij in het concrete geval wil hanteren. Hij moet bepalen welke taken hij zelf (en/of onder zijn verantwoordelijkheid) uitvoert, en welke taken hij zal uitbesteden aan de markt. Hoeven marktpartijen alleen te bouwen, of moeten ze ook ontwerpen, engineeren, financieren, beheren, exploiteren? Als de aanbesteder hieromtrent keuzes heeft gemaakt, is de volgende vraag hoe uitbesteed zal worden. Alle taken bij één partij neerleggen, of juist separaat diverse specialisten contracteren? Afhankelijk van de keuzes die hierbij gemaakt worden is er telkens sprake van een andere bouworganisatievorm.

\section{Ten aanzien van Rechtmatigheid:}

een aanbesteder is in beginsel vrij in de keuze van de bouworganisatievorm in een concreet geval. Het BAO bevat geen bepalingen die beperkingen opleggen ten aanzien van de vraag wat op de markt te zetten en hoe dat als bouworganisatievorm zijn beslag zou kunnen krijgen. Het BAO stelt wel dat de vraag zodanig geformuleerd dient te worden dat aanbieders redelijkerwijs kunnen begrijpen wat de vraag behelst (вAO artikel 23 lid 3 sub в).

Ten aanzien van doelmatigheid:

de Leidraad maakt melding van het feit dat aanbesteders nog te vaak kiezen voor de traditionele vorm, ook als er duidelijke indicaties bestaan dat met een andere vorm voordelen zijn te behalen (dit vormt tegelijkertijd de motivatie hierover enkele opmerkingen op te nemen). De keuze die een aanbesteder maakt ten aanzien van de bouworganisatievorm hangt nauw samen met de keuzes die hij maakt met betrekking tot de vraagspecificatie. Indien een aanbesteder een aannemer behalve het bouwen van een pand ook het langjarig onderhoud wil opdragen, dan doet hij er goed aan bij de vraagspecificatie voldoende oplossingsvrijheid te bieden zodat deze aannemer ook de ruimte heeft om keuzes voor bijvoorbeeld materialen en de verwerking daarvan te maken die leiden tot lage onderhoudslasten.

De belangrijkste bevindingen ten aanzien van de keuze voor een bouworganisatievorm worden in onderstaand kader weergegeven.

\section{Samenvattend:}

\section{Rechtmatigheid:}

aanbesteders zijn vrij in de keuze voor een bouworganisatievorm.

\section{Doelmatigheid:}

het heeft de voorkeur wat dat betreft een bewuste keuze te maken en te kijken naar de geschiktheid van een geïntegreerde of alliantiebenadering voor het onderhavige project. De zogenoemde projectkarakteristieken zijn van groot belang bij de te volgen aanpak. De keuzes die hier gemaakt worden moeten zich verhouden (voldoende consistent zijn met) tot de keuzes ten aanzien van de vraagspecificatie. 


\section{B Beslissingen t.a.v. de vraagspecificatie}

Introductie:

met de vraagspecificatie wordt hier bedoeld een document waarin de aanbesteder zijn vraag heeft geformuleerd aan de hand van een aantal eisen. Dit document vormt aldus de basis voor de inschrijving van marktpartijen. Afhankelijk van de wijze waarop de aanbesteder deze eisen formuleert, is er voor de marktpartijen meer of juist minder oplossingsvrijheid. Het bepalen van de mate van oplossingsvrijheid vormt de belangrijkste beslissing die de aanbesteder ten aanzien van de vraagspecificatie moet nemen. Vraagspecificaties kunnen technisch gedetailleerd zijn, maar ook kunnen ze in functionele termen (in een zekere mate 'oplossingsvrij') beschreven zijn.

Ten aanzien van Rechtmatigheid:

een aanbesteder is juridisch gezien vrij in de keuze die hij hieromtrent wil maken. в AO Artikel 23 lid 3 sub в еn с spreken letterlijk van "prestatie-eisen en functionele eisen". De formulering van deze eisen moet wel zodanig (concreet) zijn dat inschrijvers "het voorwerp van de overheidsopdracht kunnen bepalen en de aanbestedende dienst de overheidsopdracht kan gunnen" (BAO artikel 23 lid 3 sub B). Toch is de juridische vrijheid van de aanbesteder met betrekking tot het formuleren van eisen niet onbeperkt. De specificatie mag niet tot een ongeoorloofde beperking van mededinging leiden (waardoor slechts een beperkt aantal marktpartijen kan meedingen). Dit is opgenomen in artikel 23 lid 2 en lid 11. Ook mogen deze eisen niet disproportioneel zijn. Het bij de vraagspecificatie betrekken van marktpartijen die ook voornemens zijn deel te nemen aan het aanbestedingsproces is aan juridische grenzen gebonden. Een eventuele informatievoorsprong door participatie in het voortraject moet worden geneutraliseerd en als dat niet kan moeten partijen met een dergelijke voorsprong uitgesloten worden van deelname aan de aanbesteding.

\section{Ten aanzien van Doelmatigheid:}

hier wordt kort op ingegaan omdat beslissingen in dit kader (hoe formuleer ik mijn vraag; met veel of met weinig oplossingsvrijheid?) worden beïnvloed door eerder genomen beslissingen met betrekking tot de bouworganisatievorm. In grote lijnen is het zo dat bij traditionele bouworganisatievormen technisch specificeren meer voor de hand ligt terwijl bij geïntegreerde bouworganisatievormen oplossingsvrij

(functionele en/of output/prestatie eisen) specificeren meer aangewezen

De belangrijkste bevindingen ten aanzien van de vraagspecificatie worden weergegeven in onderstaand kader.

\section{Samenvattend:}

\section{Rechtmatigheid:}

aanbesteders zijn vrij in de keuze tussen het hanteren van een technische specificatie (traditioneel bestek dat materialen en verwerkingswijzen voorschrijft) ofwel een oplossingsvrij gespecificeerde vraagformulering. Formuleringen mogen niet discriminerend zijn, moeten proportioneel zijn en voldoende duidelijk maken wat de overheidsopdracht betreft.

\section{Doelmatigheid:}

het is verstandig bij deze keuze rekening te houden met de eerder gemaakte keuze ten aanzien van de bouworganisatievorm; beide keuzes dienen tot een logisch en samenhangend geheel te leiden.

\section{Beslissingen t.a.v. de contractvorm}

\section{Introductie:}

met de inschrijver wiens oplossing als beste uit de bus komt, zal de aanbesteder in de regel een contract sluiten. Met zo een contract komen opdrachtgever en opdrachtnemer economische, technische en juridisch administratieve voorwaarden overeen die vanaf dat moment tussen hen gelden.

\section{Ten aanzien van Rechtmatigheid:}

een aanbesteder heeft een aanzienlijke mate van vrijheid bij het bepalen van de inhoud van de juridische en administratieve voorwaarden. Het proportionaliteitsbeginsel speelt hierbij ook weer een belangrijke rol. Onevenwichtige voorwaarden kunnen als disproportioneel worden 
aangemerkt en staan op gespannen voet met het aanbestedingsrecht omdat mededinging hierdoor op ongeoorloofde wijze wordt beperkt. Het BAO bevat bepalingen (BAO artikelen 32, 33 en 43) die zien op het hanteren van raamovereenkomsten en dynamische aankoopsystemen, maar stelt verder geen specifieke voorwaarden aan contractering die aanvullend zijn op het contractenrecht.

\section{Ten aanzien van Doelmatigheid:}

de Leidraad beveelt aan zoveel mogelijk gebruik te maken van door en binnen de sector ontwikkelde standaardcontracten zoals bijvoorbeeld $\mathrm{UAV}(\mathrm{gc})$ en modelovereenkomsten voor Bouwteam en DBFMO contracten. De keuze voor een bepaalde contractvorm moet zich verhouden tot eerder gemaakte keuzes ten aanzien van bouworganisatievorm en vraagspecificatie. De aan de markt geboden oplossingsvrijheid, moet immers consistent worden doorvertaald naar de contractuele/juridische weergave van de verdeling van verantwoordelijkheden en risico's.

De belangrijkste bevindingen ten aanzien van de contractvorm worden onderstaand weergegeven.

Samenvattend:

\section{Rechtmatigheid:}

het BAO bevat voor contractering (niet betreffende raamovereenkomsten, dynamische aankoopsystemen en concessieovereenkomsten voor openbare werken) geen nadere bepalingen die verder gaan dan het contractenrecht.

\section{Doelmatigheid:}

het heeft de voorkeur waar mogelijk gebruik te maken van beschikbare standaardcontracten. De gekozen contractvorm moet zich verhouden tot de eerder gemaakte keuzes ten aanzien van bouworganisatievorm en vraagspecificatie.

\section{Beslissingen t.a.v. de aanbestedingsprocedure}

Introductie:

zoals in Bijlage viII te lezen valt, zijn er een aantal verschillende procedures die aanbesteders kunnen hanteren om de vraag in de markt te zetten en concurrentie op te roepen ${ }^{55}$. De aanbesteder zal op voorhand een beslissing moeten nemen met betrekking tot de keuze voor de te hanteren procedure.

Ten aanzien van Rechtmatigheid:

indien een aanbesteder Europees moet aanbesteden, kan hij alleen vrijelijk kiezen uit de openbare en de niet openbare procedure (beide procedures met algemene bekendmaking). Gebruik van de concurrentiegerichte dialoog en de onderhandelingsprocedures is alleen onder nadere voorwaarden toegestaan.

\section{Ten aanzien van Doelmatigheid:}

de Leidraad beveelt in beginsel aan zoveel mogelijk te kiezen voor procedures die algemeen aankondigen. Deze procedures voorzien in royale ruimte voor mededinging. Wel is het zo dat deze procedures in het algemeen voor hogere administratieve lasten en hogere transactiekosten zorgen. Aan dit dilemma kan ontkomen worden door te kiezen voor een procedure die algemeen bekend gemaakt moet worden, maar wel de mogelijkheid biedt in een vroeg stadium het aantal marktpartijen te reduceren dat een inschrijving mag doen: de niet openbare procedure Daarnaast luidt de aanbeveling om bij geïntegreerde- en alliantie projecten zoveel mogelijk gebruik te maken van de concurrentiegerichte dialoog.

De belangrijkste bevindingen ten aanzien van de te kiezen aanbestedingsprocedure worden op de volgende pagina weergegeven.
${ }^{55}$ Wanneer er sprake is van Europees Aanbesteden. 


\section{Samenvattend:}

\section{Rechtmatigheid:}

alleen uit de openbare en niet openbare procedure kan vrijelijk worden gekozen. Voor de overige procedures geldt dat er nadere voorwaarden zijn om deze procedures toe te kunnen passen.

\section{Doelmatigheid:}

de keuze voor een aanbestedingsprocedure moet zoveel mogelijk aansluiten bij eerder gemaakte keuzes ten aanzien van bouworganisatievorm, vraagspecificatie en contractvorm. Bij geïntegreerde contracten en alliantievorming is de concurrentiegerichte dialoog een aantrekkelijke optie.

\section{E Beslissingen t.a.v. uitsluitingsgronden, kwalitatieve geschikt-} heidseisen en selectiecriteria

\section{Introductie:}

een aanbestedende dienst moet op voorhand beslissingen nemen ten

${ }^{56}$ Uitsluitingsgronden (artikelen 45, 46 en 47 van het BAO) hebben betrekking op omstandigheden die de gegadigde of inschrijver betreffen en die diens uitsluiting van deelname aan aanbestedingsprocedures in het algemeen kunnen rechtvaardigen.

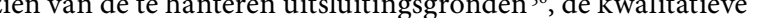
geschiktheidseisen en de selectiecriteria. Hierbij gaat het om gronden, eisen en criteria die betrekking hebben op de kwalitatieve beoordeling en selectie van ondernemingen tijdens het aanbestedingsproces. Het gaat dus om maatstaven die gehanteerd worden bij de kwalitatieve beoordeling en selectie van gegadigden: "het beoordelen van de geschiktheid van aanbieders kan aan de hand van met name hun knowhow, efficiëntie, ervaring en betrouwbaarheid" (Pijnacker Hordijk, 2004). De aanbesteder moet bijvoorbeeld beslissen of hij naast de wettelijk voorgeschreven (dwingende) gronden gebruik maakt van de mogelijkheid facultatieve uitsluitingsgronden te hanteren (als hij daarvoor kiest moet hij dit wel al in de aankondiging bekend maken). Ook het wel of niet hanteren van (nadere) selectiecriteria als aanvulling op de geschiktheidseisen is een voorbeeld van een in dit kader te nemen beslissing. En zo ja, welke criteria moeten dat dan in een concreet geval zijn?

\section{Rechtmatigheid:}

paragraaf 12 van het BAO behandelt uitsluitingsgronden, (minimum) geschiktheidseisen en criteria die in respectievelijk de selectie- en gunningsfase toepasbaar zijn. Het BAO schrijft voor dat eerst gekeken dient te worden naar het voldoen aan eisen met betrekking tot integriteit. Dit wordt geconcretiseerd in de vorm van uitsluitingsgronden. Uitsluitingsgronden hebben betrekking op integriteitseisen ten aanzien van het niet correct afdragen van premies, het niet voldoen va verschuldigde belastingen, het veroordeeld zijn voor criminele activi-

teiten, het aantoonbaar tekortgeschoten zijn ten opzichte van beroepscodes en het aantoonbaar begaan hebben van ernstige en verwijtbare fouten (zie BAO artikelen 45 sub 1 tot en met $3 \mathrm{~A}$ tot en met 3G). Aanbestedende diensten moeten deze partijen uitsluiten. Aan partijen die niet uitgesloten worden, mogen nadere eisen gesteld worden die verband dienen te houden met het aan te besteden werk (вAO artikel 44 lid 1). Deze geschiktheidseisen moeten "de toets van proportionaliteitsbeginsel en gelijkheidsbeginsel doorstaan; ze moeten in voldoende mate objectief zijn en in redelijke verhouding staan tot voorwerp en omvang van de opdracht" (Pijnacker Hordijk, 2004). Deze eisen betreffen de zogenaamde financiële en economische draagkracht en de technische- en beroepsbekwaamheid. Samen vormen deze eisen het kader waarbinnen de selectie van geschikte partijen plaats dient te vinden.

De financiële en economische draagkracht kan volgens BAO artikel 48 aangetoond worden aan de hand van bankverklaringen, bewijzen van verzekering, financiële balansen, omzetgegevens van de afgelopen (maximaal drie) boekjaren. Ook andere documenten en verklaringen waarmee een ondernemer aan kan tonen dat hij over voldoende financiële resources kan beschikken zijn geoorloofd. De technische bekwaamheid of beroepsbekwaamheid van de ondernemer dient de aanbestedende dienst te beoordelen aan de hand van BAO artikel 49 to en met 53. BAO Artikel 49 gaat in op de manier waarop ondernemers hun geschiktheid kunnen aantonen, waarbij wordt aangegeven dat telkens een keuze gemaakt kan worden uit de items die bij 49 sub $2 a$ tot en met $2 \mathrm{k}$ worden behandeld. De keuze moet overigens passen bij de omvang en de aard van het aan te besteden werk, levering of dienst (zie BAO artikel 49 sub 2).

Ervaringseisen hebben als doel vast te stellen of de aanbieder in staat is de opdracht uit te voeren. "Hieraan kan invulling gegeven worden door de aanbieder gegevens te laten overleggen over uitgevoerde opdrachten waarvan het voorwerp overeenstemt met dat van de aanbe- 
stede opdracht" (Pijnacker Hordijk, 2004).

Verder maakt Pijnacker Hordijk (2004) nog melding van de volgende inkaderende opmerkingen:

- De aanbesteder is in beginsel vrij in de keuze van een selectiemethode zolang deze methode vatbaar is voor toetsing achteraf en vooraf in de selectieleidraad is beschreven.

- Het hanteren van een puntensysteem kan in beginsel een objectieve wijze van keuzebepaling betekenen. De aanbesteder dient wel te communiceren hoe hij de verschillende onderdelen zal waarderen.

- Het inwinnen van informatie bij derden levert een onaanvaardbaar subjectief keuze element op.

\section{Doelmatigheid:}

geschiktheidseisen (minimumeisen en selectiecriteria) hebben de functie het risico te beperken ten aanzien van discontinuiteit, insolvabiliteit, onvoldoende capaciteit, en het door een marktpartij leveren van een prestatie van onvoldoende kwaliteit. Het verdient dan ook aanbeveling bij het hanteren van deze eisen te vertrekken vanuit het nu aan te besteden werk; welke eisen zijn redelijk en passend gezien de opgave? Voor geschiktheidseisen geldt dat ze proportioneel moeten zijn en dat ze op begrijpelijke en eenduidige wijze geformuleerd moeten worden. Voor wat betreft proportionaliteit geeft de Leidraad aan dat voor

${ }^{57}$ Dit betreft geen harde juridische grenzen. Het gaat meer om gezichtspunten die algemeen gehanteerd kunnen worden zodat aanbesteders 'in de veilige zone zitten'. In specifieke situaties kan proportionaliteit tot afwijkende grenzen leiden. Dit moe dan weer terug te voeren zijn tot wat de specifieke bouwopgave vraagt.

\section{Samenvattend:}

\section{Rechtmatigheid:}

partijen die op basis van de uitsluitingsgronden niet mogen deelnemen, moeten door aanbestedende diensten worden uitgesloten. Daarnaast mogen aanbesteders (nadere) proportionele eisen stellen aan de aanbieders die hun financiele draagkracht en vakbekwaamheid regarderen. De wet biedt een duidelijk kader waarop wel geselecteerd mag worden en waarop niet, alsmede welke bewijzen in dit kader mogen worden verlangd en welke niet

\section{Doelmatigheid:}

het hanteren van uitsluitingsgronden, geschiktheids eisen en aanvullende selectiecriteria is van grote invloed op de uitkomst van een aanbesteding. Daarom verdienen deze zaken tijdens de voorbereiding veel aandacht. Bij te maken keuzes hieromtrent is het zaak telkens te vertrekken vanuit de vraag: "wat vraagt de bouwopgave". Op deze wijze worden disproportionele eisen voorkomen en wordt geborgd dat de eisen die gehanteerd worden leiden naar de keuze voor een partij die het onderhavige werk met de beste kans op succes kan realiseren.

\section{F Beslissingen t.a.v. het gunningscriterium}

Introductie:

aanbestedende diensten dienen onderscheid te maken tussen criteria die ze hanteren om de geschiktheid van aanbieders te beoordelen enerzijds, en criteria op basis waarvan ze tot gunning over gaan anderzijds. Gunningscriteria hebben betrekking op de inschrijving (de bieding), selectiecriteria zien op de inschrijvers (de bieder). Bij gunning gaat het om het criterium op grond waarvan uiteindelijk gegund zal worden.

\section{Rechtmatigheid:}

BAO artikel 53 verduidelijkt dat, in geval van Europees Aanbesteden, uit twee criteria gekozen dient te worden: laagste prijs of economisch meest voordelige inschrijving (EMVI). Indien EMVI gehanteerd wordt, dient de aanbesteder het relatieve gewicht van de door hem gekozen criteria voor de bepaling van EMVI, vooraf vast te stellen en te communiceren. Indien een aanbesteder varianten toestaat, dient hij EMVI te hanteren. Dit geldt ook wanneer de concurrentiegerichte dialoog wordt gekozen, 
${ }^{58}$ Veel werken die aanbesteed worden zijn van zodanige aard dat deze proceskwaliteit essentieel is, ook omvang, complexiteit en doorlooptijd zijn vaak substantieel. Bij het aanbesteden van werken waarbi deze factoren dominant spelen, is het dus mijns inziens geoorloofd in de gunningsfase hieraan aandacht te besteden. dan is alleen EMVI als gunningscriterium geoorloofd. De wijze waarop de aanbesteder de subcriteria formuleert, moet voldoen aan de beginselen van non discriminatie en transparantie.

Wanneer een marktpartij eenmaal als geschikte partij is aangemerkt en uitgenodigd is tot het doen van een inschrijving, mag zijn ervaring en geschiktheid in beginsel geen rol meer spelen bij de beoordeling van zijn inschrijving in het licht van het gestelde gunningscriterium. Onder omstandigheden is het toegestaan hiervan af te wijken. De Leidraad spreekt hier van zogenoemde "impliciet toegstane aspecten". Dit geldt wanneer in de vraagspecificatie expliciet dan wel impliciet zaken zijn opgenomen ten aanzien van bepaalde competenties en eigenschappen waarover personen moeten beschikken om het concrete project tot een succes te kunnen maken. Vaak betreft dit competenties en eigenschappen van sleutelfunctionarissen die betrekking hebben op te realiseren proceskwaliteit. Het belang daarvan neemt evenredig toe met de omvang, complexiteit en de looptijd van een project. Denk hierbij aan aspecten als het omgaan met risico's, kwaliteitsborging, het beperken van overlast voor de omgeving, communicatie, samenwerkingsgerichtheid enzovoort ${ }^{58}$. Pijnacker Hordijk (2004) stellen overigens dat zij bij werken en leveringen geen ruimte zien voor gunningscriteria die betrekking hebben op individuele kwaliteiten. Zij stellen dat dit soort criteria alleen van toepassing zijn bij diensten waarbij specifieke persoonlijke intellectuele vermogens en/of vaardigheden een rol van betekenis spelen.

Een ander issue in dit kader is het hanteren van relatieve beoordelingen; dit dient zoveel mogelijk te worden vermeden. Met relatieve beoordelingen wordt hier bedoeld beoordelingen waarbij de score van een partij afhankelijk is van inschrijvingen en daarmee behaalde scores van andere partijen. Absolute beoordelingen hebben vanuit juridisch oogpunt, maar ook vanuit het oogpunt van doelmatigheid de voorkeur. Relatieve scores hebben namelijk het risico in zich dat 'strategisch inschrijfgedrag' van één partij de kansen van andere partijen en daarmee de uitkomst van een aanbesteding kan beïnvloeden.

\section{Doelmatigheid:}

de Leidraad beveelt aan EMVI te hanteren, tenzij er gegronde redenen zijn om dat niet te doen. Het verdient tevens aanbeveling inschrijvingen eerst te beoordelen op aspecten die verband houden met kwaliteit en vervolgens op basis van die kwalitatieve beoordeling de waarde van de inschrijving vast te stellen.

Kiest de aanbesteder voor EMVI, dan zal hij beslissingen moeten nemen ten aanzien van de te hanteren subcriteria en de daarbij behorende wegingsfactoren. Daarbij mag de aanbesteder alle aspecten hanteren zolang ze maar een economische dimensie hebben (met andere woorden: te vertalen zijn naar prijs/kwaliteit verhouding) en verband houden met de opdracht. Hierdoor heeft de aanbesteder een sturende invloed op kwaliteit en innovatie. De Leidraad adviseert kwaliteit gerelateerde aspecten voor tenminste $40 \%$ te laten meewegen ten opzichte van prijsgerelateerde aspecten. Zelfs lastig te objectiveren criteria als esthetische kenmerken mogen hierbij gehanteerd worden, als de beoordeling ervan maar op een in redelijke mate geobjectiveerde wijze geschiedt die tot gelijke kansen leidt. Ook duurzaamheidsaspecten en sociale aspecten mogen hierbij gehanteerd worden. Het verdient aanbeveling een eenvoudig en transparant systeem van subcriteria en relatieve weging daarvan te hanteren.

De belangriikste bevindingen ten aanzien van de gunningscriteria worden onderstaand weergegeven.

\section{Samenvattend:}

Rechtmatigheid:

gunnen door aanbestedende diensten kan alleen op basis van laagste prijs of EMVI Indien EMVI wordt gehanteerd dient de aanbesteder duidelijk omschreven subcriteria en hun relatieve weging vooraf bekend te maken.

\section{Doelmatigheid:}

bij complexe projecten verdient het de voorkeur kwaliteit relatief zwaar mee te laten wegen en daarop ook eerst te focussen. Pas daarna de verbinding met 'prijs' maken op een wijze die duidelijk maakt welke aanbieding de meeste waarde vertegenwoordigt. 


\section{G Beslissingen t.a.v. het uitwisselen van informatie}

Introductie:

om tot een efficiënt contract te komen, is het gewenst dat de beoogde contractpartijen vooraf relevante informatie met elkaar delen die van invloed is of kan zijn op de uiteindelijk te maken afspraken.

\section{Rechtmatigheid:}

er bestaan op dit gebied grote verschillen tussen de verschillende aanbestedingsprocedures. Het zogenoemde één op één communiceren kan van groot belang zijn. In de eerste plaats kan deze communicatie onduidelijkheden over en weer wegnemen. Voor communicatie met dit motief bestaan er geen juridische beletselen. Wel moet de aanbesteder de inzichten die hieruit voortkomen delen met andere marktpartijen die deelnemen aan de procedure (bewaken van het zogenoemde level playing field). Daarnaast kan de communicatie gericht zijn op het 'verkennen' met het oog op het nemen van een vervolgbeslissing. Communicatie die gericht is op het beïnvloeden van de ander gaat nog een stap verder. Denk daarbij aan communicatie die als motief heeft tot aanpassing van ingediende stukken te komen. Communicatie vanuit verkennende en beïnvloedende motieven is wel aan juridische beperkingen gebonden. Voorafgaande aan de inschrijving gelden bij alle procedures (behalve bij de concurrentiegerichte dialoog) beperkingen hieromtrent, maar deze beperkingen zijn zodanig dat het beter op elkaar afstemmen van vraag en aanbod wel tot de mogelijkheden behoort.

\section{Doelmatigheid:}

de Leidraad roept aanbesteders op zoveel mogelijk gebruik te maken van de ruimte voor het uitwisselen van informatie. Is er eenmaal gekozen voor een vraagspecificatie met een behoorlijke mate van oplossingsvrijheid, is het legitiem en logisch dat de aanbesteder en ook de marktpartijen meer behoefte hebben aan één op één communicatie om tot een naadloze match tussen vraag en aanbod te kunnen komen. Het verkrampt omwille van procedurele risico's zoveel mogelijk mijden van interactie betekent bij het hanteren van een vraagspecificatie met veel oplossingsruimte dat ontwikkelkansen mogelijk onbenut blijven; het wederzijds verkennen van behoeften en mogelijkheden is onderdeel van gezond marktgedrag. Bovendien biedt voornoemde interactie mogelijkheden voor productverbetering en een betere match tussen vraag en aanbod (Dorée, 2001).

De belangrijkste bevindingen ten aanzien van het uitwisselen van informatie worden in onderstaand kader weergegeven.

\section{Samenvattend:}

Rechtmatigheid:

informatieuitwisseling met de intentie de aanbieding te verhelderen is geoorloofd. Informatie uitwisseling die gericht is op beïnvloeding, wijziging van de vraag tot gevolg heeft is alleen in de concurrentiegerichte dialoog geoorloofd. Na inschrijving is de ruimte voor het uitwisselen van informatie in alle procedures gering en mag alleen sprake zijn van 'verhelderen van de aanbieding'.

Doelmatigheid:

aan het één op één uitwisselen van informatie is bij aanbesteders en marktpartijen grote behoefte, zeker als het gaat om aanbestedingen waarbij een vraagspecificatie wordt gehanteerd die veel oplossingruimte biedt. Deze afstemmingen kunnen namelijk leiden tot een betere match tussen vraag en aanbod. Het verdient dan ook aanbeveling de beschikbare ruimte ten volle te benutten.

\subsection{Verbinding Pips elementen met het juridisch kader}

Nu het juridisch kader verkend is, dringt zich de vraag op hoe de verschillende pips elementen zich verhouden tot dit kader. Om het antwoord op die vraag te vinden worden in deze paragraaf alle pips elementen achtereenvolgens behandeld waarbij naast de in de vorige paragraaf uitgevoerde verkenning van de juridische ruimte gebruik gemaakt wordt van de kennis en inzichten van specialisten van statuur op het gebied van aanbestedingsrecht (zie bijlage Ix). In de structuur van de tekst zullen dan ook telkens eerst de resultaten gememoreerd worden die de eigen verkenning heeft opgeleverd, waarna ter validatie de interview resultaten hiermee in verband gebracht worden.

Door het bestuderen van de hierboven genoemde stukken is kennis verworven die nodig was om de gesprekken met deze juristen op een betekenisvolle wijze te kunnen voeren en hun respons te kunnen 
interpreteren. Indirect heeft deze kennis dus ook bijgedragen aan de uiteenzettingen in deze paragraaf. Bij het bespreken van de juridische mogelijkheden zullen de pips elementen aan de hand van de structuur

hieronder (conform de eerder in hoofdstuk drie gehanteerde indeling

evenals verderop in hoofdstuk zes) worden behandeld:

Contactfase:

- Oplossingsvrij specificeren (Funcspec)

- Maximaal beschikbaar budget vooraf mededelen (Budginf)

- Past performance informatie mee laten wegen (PPI)

Contractfase:

- Risico's laten duiden en aan laten geven hoe men die denkt te managen; optimalisaties in laten brengen (RAVA)

- Sleutelfunctionarissen interviewen en de resultaten daarvan mee laten wegen (Qsleutelf)

- Kwaliteit/prijs verhouding mee laten wegen ( $\mathrm{Pr} / \mathrm{kwal})$

\section{Control fase:}

- Risico's overdragen (Risktrans)

- Performance management o.b.v. harde data (Harddat)

- Performance rating na oplevering (PCR)

Omdat het wettelijk kader betrekking heeft op de contact- en contractfase wordt de controlfase buiten beschouwing gelaten. Uitzondering wordt gemaakt voor het pips element Post Construction Rating (PCR) dat weliswaar tot de controlfase behoort, maar gericht is op het beïnvloeden van kansen bij nieuwe, toekomstige aanbestedingen. Deze paragraaf gaat dan ook in op de juridische mogelijkheden voor de hierboven vet weergegeven pips elementen.

\section{Oplossingsvrij specificeren (Funcspec)}

Het BAO staat volgens artikel 23 lid 3 sub в toe dat opdrachtgevers hun vraag formuleren in termen van prestatie eisen en functionele eisen. Daaraan is wel de voorwaarde gekoppeld dat deze eisen "zodanig nauwkeurig zijn bepaald dat de inschrijvers het voorwerp van de over- heidsopdracht kunnen bepalen en de aanbestedende dienst de overheidsopdracht kan gunnen".

Mijn interpretatie van bovenstaande: zolang eisen zodanig zijn verwoord dat aanbieders redelijkerwijs kunnen begrijpen waaruit de vraag bestaat en opdrachtgevers in staat zijn op voldoende geobjectiveerde wijze de beste aanbieding te selecteren, biedt het juridisch kader ruimte om functionele specificaties te hanteren.

De geïnterviewde juristen zien eveneens geen juridische belemmeringen om een vraagspecificatie te hanteren die een grote mate van oplossingsvrijheid biedt aan inschrijvers. Wel onderschrijven ze dat de vraagformulering zodanig moet zijn dat marktpartijen een voldoende helder beeld van het gevraagde kunnen vormen zodat een adequate vertaling van vraag naar oplossing redelijkerwijs mogelijk is. Alle geïnterviewde juristen geven deze zelfde uitleg en interpretatie van het wettelijk kader op dit punt.

De belangrijkste bevindingen ten aanzien van het toepassen van een oplossingsvrije vraagspecificatie worden onderstaand weergegeven.

\section{Samenvattend:}

Het juridisch kader bevat geen belemmeringen voor het toepassen van een vraagspecificatie met een grote mate van oplossingsvrijheid. Wel moeten (sub)criteria die gehanteerd worden bij het beoordelen van oplossingen voldoende concreet zijn om passende aanbiedingen en een fair vergelijk daarvan mogelijk te maken.

Maximaal beschikbaar budget vooraf mededelen (Budginf)

Het transparantiebeginsel vormt een van de fundamenten van het BAO. Van meet af aan mededelen welk budget maximaal aangewend zal worden voor de te contracteren prestaties draagt bij aan die transparantie. In het BAO zijn dan ook geen bepalingen opgenomen die zich hier tegen verzetten. Ook de Leidraad en het handboek aanbestedingsrech van Pijnacker Hordijk (2004) zien geen juridische beletselen. Verstrekken van deze informatie stelt wel eisen aan de betrouwbaarheid van de raming (zie bijvoorbeeld jurisprudentie aanbestedingsrecht van Rutten en Stalenberg, Editie 2006, blz. 47 6/80). Een betrouwbare raming is 
juridisch gezien van belang omdat ramingen die veel te krap of veel te ruim zijn aanbieders op het verkeerde been kunnen zetten. Met andere woorden de raming dient zich te verhouden tot de aan te besteden opdracht. De Leidraad stelt daarnaast dat deze werkwijze (het van meet af aan bekend maken van ISmax) transparantie bevordert en informatieasymmetrie ${ }^{59}$ vermindert.

Ook de geïnterviewde juristen zien voor toepassing van dit pips element geen beletselen in het wettelijk kader. Vooraf vermelden wat het maximale budget (ook wel maximale inschrijfsom; IS max genoemd) is dat de opdrachtgever wil aanwenden voor het verkrijgen van de door hem beoogde functionaliteiten, is juridisch gezien toegestaan.

De belangrijkste bevindingen ten aanzien van het vooraf bekend maken van het beschikbare budget worden onderstaand weergegeven.

\section{Samenvattend:}

Het vooraf bekend maken van het budget dat maximaal aangewend zal worden (een zogenoemde maximale inschrijfsom; IS max) staat niet op gespannen voet met het juridisch kader. Dat geldt ook voor het terzijde leggen van aanbiedingen die een dergelijke ISmax overschrijden, mits dit als zodanig is aangekondigd. Een betrouwbare raming vormt wel een voorwaarde voor deze werkwijze. Vanuit juridische optiek draagt deze werkwijze bij aan transparantie. Daarnaast verkleint deze werkwijze de informatieasymmetrie.

\section{Past performance informatie mee laten wegen (PPI)}

Het mee laten wegen van prestaties uit het verleden is aan regels

gebonden. Het BAO geeft aan dat technische bekwaamheid en ervaring alleen mee mag wegen bij de geschiktheidseisen en de (nadere) selectiecriteria. Het van 'derden' inwinnen van informatie (zoals bij de

Kashiwagi aanpak geschiedt) levert een onaanvaardbaar subjectief keuze element op (Pijnacker Hordijk, 2004). De interpersoonlijke relatie die aannemers met hun voormalig opdrachtgevers hadden en hebben kan de door deze opdrachtgevers toe te kennen rapportcijfers beïnvloeden. Ook ten aanzien van proportionaliteit sluit de Kashiwagi aanpak (die marktpartijen van zo veel mogelijk van hun beste projecten PPI info laat inleveren) niet aan bij het juridisch kader. Om aan bovenstaande bezwaren tegemoet te komen, en toch de vruchten van het 'reputatiemechanisme ${ }^{60}$ te kunnen plukken is een alternatieve wijze van PPI hanteren ontwikkeld ${ }^{61}$. Daarbij wordt vertrokken vanuit de bouwopgave en worden enkele karakteristieke elementen benoemd die voor het concrete project wezenlijk zijn. Vervolgens wordt van gegadigden gevraagd op een verifieerbare wijze te beschrijven hoe ze in het verleden bij drie afgeronde, vergelijkbare en met naam en toenaam bekend te maken projecten met deze elementen om zijn gegaan en waartoe dat heeft geleid ${ }^{62}$. Daarbij wordt ook concreet aan gegeven wat onder vergelijkbare projecten verstaan wordt. Hiermee wordt tegemoet gekomen aan de bezwaren ten aanzien van disproportionaliteit, subjectiviteit en transactiekosten. Bovendien wordt een duidelijke relatie gelegd met het onderhavige project waardoor de PPI betekenisvoller wordt voo wat betreft risico reductie voor het nu aan te besteden project.

Mijn interpretatie van de juridische ruimte komt er dan ook op neer dat het hanteren van PPI op de wijze zoals in het kader van dit onder zoek ontwikkeld (zie hoofdstuk vijf, UMC St Radboud fase III) niet in conflict is met het juridisch kader. Ook Chao-Duivis $(2005,2006)$ heeft onderzoek gedaan naar de juridische haalbaarheid van de wens om gegadigden op hun past performance te onderzoeken. Zij komt tot de conclusie dat dit wel kan tijdens de selectiefase ${ }^{63}$, zolang het maa proportioneel, voor ieder gelijk, objectief en transparant gebeurt. Het mee laten wegen van PPI is volgens de geïnterviewde juristen toe-

${ }^{62}$ De wens om de Kashiwagi PPI werkwijze te modificere komt niet alleen voort uit de juridische bezwaren daartegen, maar ook vanuit doelmatigheidsoverwegingen PPI die relevant is voor het nu aan te besteden werk en
${ }^{60}$ Zie hoofdstuk drie voor uitleg en werking van het reputatiemechanisme.

${ }^{61}$ Voor het eerst toegepast bij de aanbesteding van Fase III van de nieuwbouw van UMC St Radboud, daarna ook toegepast bij de aanbesteding van het bergbezinkbassin in opdracht van de gemeente

's-Hertogenbosch en de aanbesteding van een 'inbreiproject' van corporatie Land van Rode (zie Bijlage $\mathrm{x}$ ) en inmiddels ook bij de overige in dit proefschrift genoemde aanbestedingen.

ingaat op hoe de aanbieder in eerdere projecten om is gegaan met voor dit werk karakteristieke uitdagingen is informatiever vergeleken bij enkel rapportcijfers die toegekend zijn door voormalig opdrachtgevers.

${ }^{6} 3$ PPI betreft immers de bieder; niet de bieding. 
${ }^{64}$ Bij de uitgevoerde praktijkcases wordt daarom telkens een zwaarder gewicht aan de current- dan aan de past performance toegekend. gestaan zolang dat proportioneel, objectief, transparant en op een wijze gebeurt die niet leidt tot ongelijke behandeling van marktpartijen. De BAO artikelen 44 en 49.2.A. bieden daartoe de ruimte. Verder waar-

schuwden enkele geïnterviewde juristen ervoor een te groot belang aan PPI toe te kennen ${ }^{64}$. Er kan immers inmiddels het een en ander gewijzigd zijn bij de aannemers. Denk hierbij aan mutaties in het personeelsbestand, nieuwe investeringen in equipement, fusies etc. Ook kan het (te) zwaar mee laten wegen van PPI mededinging dempen doordat altijd dezelfde happy few op grond van in het

verleden uitgevoerd werk geselecteerd worden. Dat zou innovatie en concurrentie kunnen afremmen.

De belangrijkste bevindingen ten aanzien van PPI worden hieronder weergegeven.

\section{Samenvattend:}

Het hanteren van PPI en de kwaliteit ervan mee laten wegen bij een aanbesteding is geoorloofd. Wel moet dit op een voldoende geobjectiveerde en proportionele wijze geschieden. De Kashiwagi methode komt aan deze eisen niet geheel tegemoet. De in het kader van dit onderzoek ontwikkelde werkwijze vormt hiervoor een remedie. Een te groot (disproportioneel) belang hechten aan PPI kan mededinging remmen en dient te worden voorkomen.
${ }^{65}$ In zijn eerste Best Value Procurement boek noemt Dean deel RAP: Risk

Assessment Plan. In de 2009 versie is dit omgewerkt tot RAVA naast de oriëntatie op risicomanagement is hieraan een oriëntatie op het gebied van "optimalisaties die toege-

$$
\text { lees verder ---> }
$$
Kashiwagi dit onder- relevantie daarvan is evident. De Leidraad stelt dat de functie van (gunnings)criteria is de inschrijving te selecteren die met de grootste kans op succes de concrete opdracht tot een goed einde kan brengen tegen zo laag mogelijke totaalkosten. Daarnaast somt de Leidraad een aantal invalshoeken op waaraan aandacht besteed kan en mag worde in het kader van het operationaliseren van EMvi. Daarbij worden productkwaliteit, risico management en -verdeling expliciet genoem De juridische rechtmatigheid vanuit het BAO en de doelmatigheidstoet vanuit de Leidraad leiden beiden tot een positief oordeel voor dit pips element.

De geïnterviewde juristen zien ook geen juridische beletselen vanui het BAO om de kwaliteit van RAVA als subcriterium van EMVI mee te laten wegen, zolang beoordeling ervan maar op een wijze geschiedt die tot gelijke kansen leidt. Het laten beoordelen van geanonimiseerde RAVA's kan daartoe bijdragen ${ }^{66}$

De belangrijkste bevindingen ten aanzien van het toepassen van RAVA's worden onderstaand weergegeven.

\section{Samenvattend:}

De kwaliteit van RAVA's mee laten wegen is in het kader van een EMVI gunning als subcriterium toegestaan, zolang dit niet op gespannen voet met de aanbestedingsbeginselen objectiviteit en non-discriminatie staat.

\section{Sleutelfunctionarissen interviewen en de resultaten daarvan} mee laten wegen (Qsleutelf)

Tijdens de selectiefase mag er niet gewerkt worden met één op één interviews. In die fase zijn alleen de limitatief opgesomde zaken uit BAO artikel 49 toegestaan. Zoals we eerder zagen is het tijdens de gunningsfase alleen in uitzonderingsgevallen toegestaan aandacht te besteden aan individuele competenties van sleutelfunctionarissen. Pijnacker Hordijk stellen zelfs dat dit in hun optiek alleen speelt bij 'diensten' waarbij bijvoorbeeld gedacht kan worden aan persoonlijke intellectuele vermogens die van doorslaggevend belang zijn voor de aan te besteden opdracht. De Leidraad en ook het rapport "Gunnen op waarde" (Pries \& van Reeuwijk, 2007) bieden op dit punt meer ruimte. Wanneer het

voegde waarde vergroten" toegevoegd. nen hierin beschrijven waaruit de toegevoegde waarde die uitstijgt boven minimum vereisten, van hun kant leiden.

${ }^{66}$ Bij de uitgevoerde RAVA's inderdaad anoniem beoordeeld Marktpartijen kun-

van hun inschrijving bestaat, in hoeverre tot welke 'plus' optimalisatie initiatieven praktijkcases hebben beoordelaars de Indien EMVI gehanteerd wordt als gunningscriterium staat het BAO toe aanbieders te vragen risico's te duiden en te beschrijven hoe deze risiso's gemanaged zullen worden. Het BAO bevat namelijk geen limitatieve opsomming van subgunningscriteria. Subcriteria zijn geoorloofd zolang ve maar een economische dimensie hebben en in voldoende maten met het aan te besteden werk. De economische dimensie bestaat eruit dat een partij die een kwalitatief goed RAVA inlevert een grotere kans op projectsucces impliceert (vergeleken met een partij die een minder goed RAVA inlevert), lagere faalkosten zal kennen, en efficiënter en doelgerichter zal werken; de economische 
belang van proceskwaliteit en de daarvoor benodigde competenties voldoende duidelijk doorklinkt in de vraagstelling (en overige aanbestedingsdocumenten zoals de selectie- en gunningsleidraad) is het geoorloofd bij het operationaliseren van EMVI aandacht te besteden aan zaken als samenwerkingsvermogen, kwaliteitsborging en voor het project vereiste (vaktechnische, samenwerkings- en sociaal communicatieve) competenties voor zover deze relevant zijn voor het realiseren van de benodigde proceskwaliteit. Indien er sprake is van een project waarbij het belang van deze individuele kwaliteiten expliciet is aangegeven, is het de vraag of het beoordelen van deze kwaliteiten mag geschieden door middel van het houden van één op één interviews. Aanvullend onderzoek in het kader van de aanbesteding van het bergbezinkbassin in opdracht van de gemeente 's-Hertogenbosch heeft opgeleverd dat deze interviews plaats kunnen vinden tegen een aanvaardbaar claimrisico op voorwaarde dat alle aanbieders gelijk

behandeld worden en de interviews in voldoende mate geobjectiveerd worden (o.a. zelfde vragen, zelfde team, werken met gemiddelde score van beoordelaars). Ook dient vooraf kenbaar gemaakt te worden welke elementen bij de beoordeling van het interview betrokken worden. Verder dient voorkomen te worden dat tijdens de interviews teruggegrepen wordt op zaken die bij de selectie van partijen al een rol hebben gespeeld.

Mijn interpretatie komt erop neer dat het interviewen van sleutelfunctionarissen alleen kan tijdens de gunningfase bij die projecten waarbij de kwaliteiten van sleutelfunctionarissen van dominant belang zijn en dit ook als zodanig uit de aanbestedingsstukken blijkt. Bovendien moeten de interviews zodanig plaatsvinden dat voldaan wordt aan de aanbestedingsbeginselen, waarbij met name aandacht besteed dient te worden aan de beginselen ten aanzien van objectiviteit en het bieden van gelijke kansen.

Tijdens de interviewronde in 2006 werd een divers beeld geschetst van de juridische mogelijkheden met betrekking tot dit pips element. Een volmondig "ja" werd niet geuit. Wel werden er de nodige voorwaarden en zorgen uitgesproken rondom dit pips element. Het interviewen van sleutelfunctionarissen behoort alleen tot de mogelijkheden wanneer de inzet van sleutelfunctionarissen met bepaalde specifieke competenties te vertalen is naar een economische waarde voor het project. Het interviewen van sleutelfunctionarissen kan daartoe (in de gunningsfase) een geëigend middel zijn ${ }^{67}$ op voorwaarde dat een en ander voldoende geobjectiveerd en transparant plaatsvindt en ongelijke behandeling wordt voorkomen ${ }^{68}$. Ook moet voorkomen worden dat de interviews ingaan op onderwerpen die bij de selectiefase al hebben meegewogen.

Spreekt het belang van proceskwaliteit in onvoldoende mate uit de vraagspecificatie, dan is het niet geoorloofd de kwaliteit van sleutelfunctionarissen te betrekken bij het proces om te komen tot contractering van de meest gerede partij.

De belangrijkste bevindingen ten aanzien van het interviewen van sleutelfunctionarissen worden onderstaand weergegeven.

\section{Samenvattend:}

7 De Leidraad Aanbesteden voor de bouw noemt in dit kader ook expliciet "kwaliteit van het team"

${ }^{68}$ Zorg bijvoorbeeld voor een standaard vragenlijst, het maken van audioopnames en een vast team dat de interviews afneemt. In dat team kan eventueel een onafhankelijke deskundige worden opgenomen.

Het één op één interviewen van sleutelfunctionarissen in de gunningsfase van een aanbesteding vormt een item waarover deskundigen geen eensluidende mening geven. Mijn interpretatie luidt dat indien voor het welslagen van een project de competenties van sleutelfunctionarissen van dominant belang zijn en dit belang in voldoende mate doorklinkt in de aanbestedingsstukken, het geoorloofd is deze functionarissen in de gunningsfase te interviewen en de resultaten daarvan mee te wegen. Wel moeten er voldoende maatregelen getroffen worden om gelijke kansen en geobjectiveerde beoordeling te borgen. De juridische discussie op dit punt wordt verder gecontinueerd.

\section{Kwaliteit/prijs verhouding mee laten wegen ( $\mathrm{Pr} / \mathrm{kwal})$}

Het BAO maakt melding van EMVI als gunningscriterium. EMVI is in essentie juist gericht op de prijs/kwaliteitverhouding. Het BAO bevat dan ook geen restricties om prijs/kwaliteit verhouding mee te laten wegen. Wel moet EMVI in voldoende duidelijke mate worden geoperationaliseerd; subgunningscriteria moeten in voldoende mate objectief hanteerbaar zijn (Pijnacker Hordijk, 2004).

Ook alle geïnterviewde juristen geven aan dat het BAO voldoende ruimte 
biedt om de kwaliteit van oplossingen te laten meewegen om tot één partij te komen aan wie de opdrachtgever wil gunnen. Wel is hier de voorwaarde aan verbonden dat het gunningscriterium EMvi wordt gehanteerd en dat dit criterium in voldoende mate wordt geconcretiseerd in de vorm van subcriteria en eventueel bijbehorende wegingsfactoren.

De belangrijkste bevindingen ten aanzien van het mee laten wegen van de kwaliteit van de oplossingen worden onderstaand weergegeven.

\section{Samenvattend:}

Er zijn geen belemmeringen vanuit het juridisch kader om het onderscheidend vermogen dat spreekt uit de kwaliteitsverschillen van de ingebrachte oplossingen mee te laten wegen, zolang recht gedaan wordt aan de aanbestedingsbeginselen. Wel is het hanteren en volgens de regels der kunst concretiseren van het gunningscriterium EMVI voorwaardelijk voor het laten meewegen van kwaliteitsverschillen in biedingen.

\section{Performance rating na oplevering (PCR)}

Het gelijkheidsbeginsel vormt een van de fundamenten van het вaO. Dat gelijkheidsbeginsel stelt dat aanbieders bij de start van een nieuwe aanbesteding gelijke kansen moeten krijgen. Het hanteren van PCR is juist gericht op het geven van een voorsprong (al bij de start) aan die aanbieders die eerdere pips projecten goed hebben afgerond en een achterstand aan die aanbieders die eerdere pips projecten niet volgens de regels der kunst tot een goed einde hebben gebracht. Daarmee staat PCR haaks op, zoniet diametraal tegenover, het gelijkheidsbeginsel. PCR is in mijn interpretatie dan ook niet toepasbaar voor aanbestedende diensten.

Alle geïnterviewde juristen geven aan dat dit element zich in deze vorm niet verhoudt tot het non discriminatiebeginsel van het aanbestedingsrecht. Dit beginsel heeft als oogmerk bij aanvang gelijke kansen te creëren voor marktpartijen. Dit oogmerk wordt door het hanteren van PCR scores direct verstoord. Een marktpartij met goede PCR scores heeft bij aanvang van een nieuwe aanbestedingsprocedure namelijk op voorhand al een voordeel ten opzichte van zijn concurrenten. Met een slechte PCR score heeft deze marktpartij op voorhand al een nadeel ten opzichte van mededingers. Daarnaast wordt het bezwaar van dubbele bestraffing aangevoerd. Wanneer een marktpartij een in de ogen va de opdrachtgever tegenvallende performance laat zien tijdens een project, zal deze aannemer dit project niet gebruiken voor PPI bij volgende aanbestedingen. Deze PPI draagt immers niet bij aan positie onderscheidend vermogen ten opzichte van mede gegadigden en helpt hem dus niet zijn kansen te vergroten ${ }^{69}$. Tijdens IPPC 2008 brachten Albano en Cesi een pleidooi in om een met PCR vergelijkbare penalt te hanteren. Nadere bestudering van hun conference paper maakte echter duidelijk dat de juridische haalbaarheid niet werd onderzoch (Albano en Cesi, 2008).

De belangrijkste bevindingen ten aanzien van PCR worden onderstaan weergegeven.

${ }^{69}$ Hierin zit al een soort van penalty verdisconteerd.

Wanneer deze aan nemer daarenboven ook nog met een $1-0$ achterstand aan de nieuwe wedstrijd zou moeten beginnen wordt hij dubbel getroffen.

\section{Samenvattend:}

Het toekennen en bij nieuwe aanbestedingen gebruiken van PCR staat op gespannen voet met het geldende aanbestedingsrecht en de ongewenste neveneffecten overschaduwen (geen rële kans op nieuw werk, 'inteelt' effecten doordat bij brede toepassing telkens dezelfde selecte groep aanbieders de beste kansen heeft) bovendien de gewenste effecten ('stok achter de deur' om high performance af te dwingen). Deze 'stok achter de deur' wordt overigens al geconcretiseerd door het hanteren van PPI; goede performance op het onderhanden werk kan via de PPI weg al invloed hebben op de kans op toekomstig werk. Toepassing van PCR wordt ten sterkste ontraden. 
De toepassingsmogelijkheden van de verschillende pips elementen bezien vanuit het geldende wettelijke kader zijn als volgt samen te vatten:

pips elementen Toepasbaar $\quad \begin{aligned} & \text { Toepasbaar onder Niet toepasbaar } \\ & \text { voorwaarden }\end{aligned}$

\begin{tabular}{l|l} 
Funcspec & \\
Budginf & \\
\hline PPI $^{70}$ & $\begin{array}{l}\text { In selectiefase mits } \\
\text { voldoende objectief }\end{array}$ \\
\hline
\end{tabular}

RAVA

Qsleutelf

Meningen lopen uiteen Meningen lopen uiteen

$\operatorname{Pr} /$ kwal

EMVI $=$ voorwaarde

PCR

${ }^{70} \mathrm{PPI}$ is toepasbaar in de selectiefase als deze informatie verzameld en beoordeeld wordt op de wijze zoals in het kader van dit onderzoek ontwikkeld.

De standaard

"Kashiwagi aanpak" stuit op bezwaren.

\subsection{Pips elementen in de niet openbare aanbestedingsprocedure}

Rekening houdend met de hiervoor besproken 'juridische ruimte' die het wettelijk kader biedt voor het toepassen van de pips elementen, zijn door de auteur van dit proefschrift op basis van literatuurstudie, interviews en ervaringen met praktijkcases twee procesmodellen ontwikkeld voor de PiPS wise aanbesteding van werken volgens de niet openbare procedure. De keuze voor deze procedure is gemaakt omdat dit door aanbestedende diensten binnen de sector een vrij te kiezen en veel gebruikte procedure is. Het feit dat het binnen deze procedure mogelijk is het aantal marktpartijen 'getrapt' te reduceren vormt daarvoor een belangrijk motief: Dit heeft lagere transactiekosten tot gevolg (Constantino et al 2008, Kras \& Bennema, 2005). Onderstaand wordt de concretisering van deze procedure waarbij de pips elementen worden ingevlochten in twee varianten beschreven. In de eerste plaats voor de situatie waarbij de competenties van sleutelfunctionarissen wel van dominant belang zijn en dit ook uit de aanbestedingsstukken blijkt, en daarna voor de situatie waarin dit niet het geval is.

\section{Variant $\mathbf{1}$}

NIET OPENBARE PROCEDURE VOOR PIPS AANBESTEDINGEN WAARBIJ PROCESKWALITEIT EN DE DAARVOOR BENODIGDE COMPETENTIES VAN SLEUTELFUNCTIONARISSEN EEN DOMINANTE ROL VERVULLEN

\section{Voorbereiding:}

Ter voorbereiding op de start van de procedure maakt de aanbesteder een vraagspecificatie met een grote mate van oplossingsvrijheid en stelt een selectieleidraad op waarin duidelijk staat beschreven wat het werk behelst, wat uitsluitingsgronden, minimumvereisten en selectiecriteria zijn en hoe ze toegepast zullen worden. De aanbesteder draagt er zorg voor dat het belang van proceskwaliteit en de daarvoor benodigde competenties van sleutelfunctionarissen duidelijk doorklinken in dit document. Ook vermeldt de aanbesteder in de selectieleidraad welk budget hij maximaal zal aanwenden om te voorzien in de functionalitei- 
${ }^{71}$ PPI behoort in de selectiefase toegepast te worden

omdat PPI informatie geeft die ziet op de bieder en niet op de bieding.

${ }^{72}$ Deze drie pips elementen behoren in de gunningsfase thuis omdat ze zien op de bieding; ze betreffen dit project. ten die het concrete project moet bieden. De aanbesteder kondigt vervolgens de opdracht aan waarna gegadigden uitgenodigd worden voor een informatiebijeenkomst en ze de selectieleidraad tegelijkertijd in ontvangst kunnen nemen.

\section{Selectiefase}

Tijdens de eerste fase (selectiefase) worden marktpartijen getoetst aan uitsluitingsgronden, minimumeisen en selectiecriteria. Marktpartijen die voldoen aan uitsluitingsgronden en minimumeisen, worden gerankt aan de hand van de PPI $^{71}$ (van drie afgeronde projecten op verifieerbare wijze beschrijven hoe omgegaan is met de door de aanbesteder voor dit project van belang geachte aspecten en waartoe dat heeft geleid).

Op deze wijze brengt de aanbesteder het aantal potentieel geschikte gegadigden terug tot een beperkt aantal marktpartijen dat daadwerkelijk uitgenodigd wordt om een inschrijving te doen. PPI is daarmee een 'nader selectiecriterium' geworden dat gehanteerd wordt naast de minimum eisen. Het aantal potentieel geschikte aanbieders wordt daarmee tot een bij de bouwopgave en de marktsituatie passend aantal (dat van meet af aan vermeld staat in de selectie leidraard) teruggebracht.

\section{Gunningsfase:}

De marktpartijen die uitgenodigd worden een daadwerkelijke inschrijving te doen ontvangen een gunningsleidraad. Daarin staat onder andere beschreven welk gunningscriterium gehanteerd wordt (zal in de regel EMVI zijn) en hoe dat geoperationaliseerd wordt. Ook maakt dit document duidelijk hoe er beoordeeld zal worden en wat de planning van deze fase behelst. Tijdens deze fase komen de volgende pips elementen ${ }^{72}$ aan bod:

- Kwaliteit RAVA

- Interviewen sleutelfunctionarissen

- Kwaliteit van de oplossing/het plan

Daarna wordt de inschrijvingsprijs beoordeeld waarna de waarde/prijs verhouding bepaald kan worden. De kwaliteitgerelateerde aspecten wegen samen bijvoorbeeld $70 \%$ mee, prijs weegt voor $30 \%$ mee.

\section{Contractering:}

De partij met de beste waarde/prijs verhouding wordt uitgenodigd voor de pre award fase waarna awarding (zie voor pre-award en award hoofdstuk drie) en risico overdracht plaatsvindt.

Schematisch

${ }^{n r} 1$ Voorbereiding:

- Vraagspecificatie

- Selectie Leidraad

- Info bijeenkomst

nr 3 Gunningsfase:

- Kwal. Oploss.

- Kwal. Sleutelfunc.

- Kwal. Rava

- Prijs

Afbeelding 4.1; Schematische weergave PiPs aanbesteding variant I

Variant 2

NIET OPENBARE PROCEDURE VOOR PIPS AANBESTEDIN-

GEN WAARBIJ PROCESKWALITEIT EN DE DAARVOOR

BENODIGDE COMPETENTIES VAN SLEUTELFUNCTIONARISSEN EEN ONDERGESCHIKTE ROL VERVULLEN.

Voorbereiding:

Dit ontwerp verschilt van het vorige ontwerp doordat het interviewen van sleutelfunctionarissen niet plaats vindt in de gunningsfase. In de selectiefase is het interviewen van sleutelfunctionarissen zoals al eerder 
geconstateerd niet toegestaan. In deze variant kan dus minder prominent aandacht besteed worden aan de kwaliteit van sleutelfunctionarissen. Deze variant bevat minder juridische risico's omdat de

objectiviteit door het ontbreken van de interviews minder ter discussie staat. Bij de uiteindelijke gunning zullen verschillen in competenties tussen sleutelfunctionarissen niet meer van doorslaggevend belang kunnen zijn, omdat hieraan alleen aandacht besteed kan worden bij de stap van gegadigde naar inschrijver, maar niet meer bij het bepalen van de inschrijver aan wie gegund wordt (Hof van Justitie EG 21 januari 2008, zaak C-532/o6 (Lianakis), r.o. 30).

\section{Selectiefase:}

Aanbesteders zijn bij het toetsen van de technische bekwaamheid gehouden aan de limitatieve opsomming die het ARW 2005 vermeldt. Dit betreft een zogenaamd gesloten systeem dat geen ruimte biedt voor het interviewen van sleutelfunctionarissen. Om toch zicht te krijgen op kwalificaties mag wel gevraagd worden cv's bij te voegen en mag gevraagd worden naar diploma's, getuigschriften certificaten en dergelijke van sleutelfunctionarissen. Op deze wijze krijgt de aanbesteder echter minder goed zicht op de competenties van de beoogde sleutelfunctionarissen voor wat betreft de proceskwaliteit (maar da is ook geen dominante factor voor dit project). Interviews tijdens de selectiefase zijn zoals hiervoor al vermeld niet geoorloofd als selectiecriterium waaraan punten toe te kennen zijn. Wel mogen interviews gebruikt worden om de door de gegadigde ingeleverde informatie te controleren en/of te verduidelijken; deze interviews mogen niet afzonderlijk beoordeeld worden aan de hand van een puntensysteem.

\section{Gunningsfase}

Deze fase komt overeen met de fase uit het proces waarbij de kwaliteit van de sleutelfunctionarissen wel van doorslaggevend belang is voor projectsucces, met uitzondering van de interviews. Die vinden bij dit proces, zoals hiervoor al betoogd, niet plaats.

\section{Contractering}

De contracteringsfase verloopt qua proces conform het processchema van afbeelding 4.1.
Schematisch
${ }^{n r} \mathbf{1}$ Voorbereiding:

- Vraagspecificatie

- Selectie Leidraad

- Info bijeenkoms

nr 3 Gunningsfase:

- Kwal. Oploss

- Kwal. Plan

- Kwal. Rava

- Prijs $n r 2$ Selectiefase:

- Uitsluitings Gronden

- Minimum Eisen

- Aanvullende Eisen (bv ook cv's)

- PPI

4 Contractering.

- Pre award

- Awarding
- Risk transfer

Afbeelding 4.2; Schematische weergave PiPS aanbesteding variant II

\subsection{Deelconclusies Pips versus juridisch kader}

De voorgaande paragrafen leiden naar de volgende deelconclusies.

\section{Algemeen:}

Het juridisch kader biedt ruime mogelijkheden om invulling te geven aan Best Value Procurement. De pips elementen uit de contact- en contractfase kunnen deels zonder meer toegepast worden, deels onder voorwaarden. De controlfase valt buiten het bestek van het juridisch kader ten aanzien van aanbesteden. Toch is er een element uit de control fase dat zodanige impact heeft op toekomstige aanbestedingen, dat dit element wel onder het bereik van het juridisch kader valt: PCR.

Toepassing van dit element wordt sterk ontraden. Het hanteren van interviews met sleutelfunctionarissen is een item waarover de meningen 
verdeeld zijn. Dit element kan niet zomaar 'automatisch' in een procedure opgenomen kan worden. Dit geldt evenzo voor de prijs/kwaliteit verhouding en het gebruiken van PPI in de selectiefase. De prijs/kwaliteit verhouding kan alleen toegepast worden wanneer EMVI als gunningscriterium wordt gehanteerd. PPI kan toegepast worden in de selectiefase in de vorm zoals in het kader van dit onderzoek ontwikkeld. Voor alle toepassingen geldt dat de aanbestedingsbeginselen steeds gerespecteerd dienen te worden.

Deelconclusie

\section{1}

HET JURIDISCH KADER BIEDT AANBESTEDENDE DIENSTEN VOLDOENDE RUIMTE EN MOGELIJKHEDEN PIPS ELEMENTEN TOE TE PASSEN.

Het oplossingsvrij specificeren, het vooraf bekend maken van de maximale budgetruimte, het mee laten wegen van PPI, het laten maken van een RAVA (en de kwaliteit daarvan mee laten wegen) en het mee laten wegen van de kwaliteit van oplossingen (op voorwaarde dat EMVI wordt gehanteerd) zijn met in achtneming van de aanbestedingsbeginselen toegestaan.

\section{Deelconclusie $\mathbf{4 . 2}$}

${ }^{73}$ Zie voor een uitgewerkt voorbeeld hiervan hoofdstuk 5 aanbesteding fase III UMC ST Radboud.

${ }^{74}$ Deze methode voldoet ook aan de proportionaliteitsbepalingen zoals opgenomen in de concept tekst voor de nieuwe aanbestedingswet zoals gepubliceerd op 29 april 2009. METHODE" MINDER GEWENST, EN KOMT DE IN DIT ONDERZOEK Het laten inleveren van PPI van zoveel mogelijk projecten doet transactiekosten stijgen. Beoordelingen van voormalig opdrachtgevers kunnen beïnvloed zijn door de kwaliteit van de relatie.
HET INTERVIEWEN VAN SLEUTELFUNCTIONARISSEN EN HET MEE LATEN WEGEN VAN KWALITATIEVE VERSCHILLEN DIE UIT DEZE INTERVIEWS BLIJKEN, IS EEN PUNT VAN DISCUSSIE. AAN HET INTERVIEWEN VAN SLEUTELFUCNTIONARISSEN ZIJN NADERE VOORWAARDEN VERBONDEN TEN AANZIEN VAN OBJECTIVITEIT, TRANSPARANTIE EN GELIJKE BEHANDELING. Zie BAO, ARW 2005 en de Leidraad; het juridisch debat hieromtrent za verder voortgaan.

Deelconclusie $4 \cdot 4$

POST CONSTRUCTION RATING (PCR) SCORES DIE LEIDEN TOT ONDERSCHEID BIJ AANVANG VAN NIEUWE AANBESTEDINGEN, ZIJN NIET TOEGESTAAN ${ }^{7}$

Het nondiscriminatiebeginsel schrijft voor dat er bij de start van een aanbesteding gelijke kansen dienen te bestaan. PCR leidt juist to aanvangsverschillen die rechtstreeks van invloed zijn op winkansen.

De inpassing van pips in het in Nederland geldende juridische kade vertoont weinig knelpunten, op voorwaarde dat de aanbestedingsbeginselen (en dat geldt overigens altijd) gerespecteerd worden. De discussie spitst zich toe op de (on)mogelijkheden sleutelfunctionarissen te interviewen tijdens de gunningsfase. ONTWIKKELDE ${ }^{73}$ METHODE BETER TEGEMOET AAN DE AANBESTEDINGSBEGINSELEN OBJECTIVITEIT EN PROPORTIONALITEIT ${ }^{74}$.
${ }^{75}$ Daarnaast is toepassing van dit element minder wenselijk vanwege double punishment effecten en de invloed die dit bij bredere toepassing van pips kan hebben op mededinging ('inteelt' effecten). 


\section{Reflectie op juridische bevindingen}

\section{Inleiding:}

Het juridisch onderzoek heeft plaatsgevonden gedurende de eerste helft van de onderzoeksperiode. De interviewronde langs gespecialiseerde juristen heeft in 2006 plaatsgevonden, de link met de Leidraad is in 2009 gelegd. Een paragraaf met enkele reflecterende beschouwingen en updates naar de huidige situatie is dan ook op zijn plaats. Achtereenvolgens zal ingegaan worden op het veranderend wetgevend kader, op de brede toepassing van pips en de juridische aspecten die daarbij een rol hebben gespeeld en op de veranderingen in de pips methodiek casu quo in het gedachtegoed van Kashiwagi.

\section{Het veranderend wetgevend kader}

Het bestaande juridische kader (BAO) is aan verandering onderhevig. Aanleiding daarvoor is gelegen in het feit dat er onder de huidige wet een aantal manco's worden ervaren. Hieronder worden de belangrijkste knelpunten gememoreerd:

- Hoge kosten als gevolg van inefficiënte procedures en verschillende procedures onder de drempels.

- Rechtsonzekerheid als gevolg van onvoldoende duidelijke regelgeving

- Slechte naleving door opdrachtgevers

- Slechte toetsing integriteit en daardoor gunning aan niet integere opdrachtnemers

- Disproportionele eisen als gevolg van niet professioneel opdrachtgeverschap

De invoering van een nieuwe aanbestedingswet is aanstaande. Het eerste wetsvoorstel is in 2008 door de eerste kamer verworpen. De nieuwe aanbestedingswet moet zorgen voor een gelijk speelveld voor alle ondernemers, groot en klein. Daarom bevat het nu liggende voorstel regels ten aanzien van het clusteren van opdrachten. Tweede Kamerleden reageerden kritisch positief op het voorstel voor de Aanbestedingswet dat de minister begin april 2011 naar het parlement stuurde (Cobouw.nl 5 april 2011). In februari 2012 heeft de Tweede Kamer ingestemd met het voorliggende wetsvoorstel en ter behandeling doorgestuurd naar de Eerste Kamer die op 30 oktober 2012 daarmee ook heeft ingestemd. De verwachting is dat de nieuwe wet per 1 april 2013 of 1 juli 2013 in werking zal treden.

Het vernieuwde juridische kader (bron: $w w w$.pianoo/belangrijkstewijzigingen) besteedt extra aandacht aan proportionaliteit (de zogeheten proportionaliteitsgids) om daarmee de kansen voor мкв marktpartijen te vergroten. Ook is het beginsel 'EMVI tenzij' in het nieuwe kader opgenomen.

Aanbesteders worden op grond van de nieuwe Aanbestedingswet geconfronteerd met een aantal veranderingen: EMVI tenzij,... (Aanbestedende diensten moeten bovendien "zoveel mogelijk maatschappelijke waarde creëren bij het aangaan van een overeenkomst"), de verplicht te hanteren proportionaliteitsgids die ziet op het stellen van eisen die zich in redelijke mate verhouden tot wat het aan te besteden werk vraagt zijn hier enkele belangwekkende voorbeelden van (overigens zal met betrekking tot het invulling geven aan het proportionaliteitsbeginsel nog een aanvullende $\mathrm{AMvB}$ worden uitgevaardigd die in dit kader als richtsnoer zal dienen voor aanbesteders). Bij geschiktheidseisen mag omzet alleen nog maar een rol spelen als de aanbesteder daartoe zwaarwegende redenen aanvoert. En dan nog mag de eis maximaal $300 \%$ van het nu aan te besteden werk bedragen. Met deze maatregel wordt disproportionaliteit verder teruggedrongen. Verder zullen aanbesteders hun procedures gedetailleerder voor moeten bereiden en zullen ze keuzes die ze daarbij maken in hogere mate dienen te motiveren. Dat begint al bij de keuze voor de procedure die wordt gekozen en voor de marktpartijen die worden toegelaten. Voor aanbestedende diensten geldt bovendien dat ze alle aanbestedingen op Tenderned dienen te publiceren.

Ook het terugdringen van administratieve lasten vormt een doel waaraan de nieuwe Aanbestedingswet dient bij te dragen. Dit komt bijvoorbeeld tot uitdrukking in een nieuw uniform model "Eigen Verklaring". Ook dient de aanbesteder alle aanbestedingsstukken kosteloos ter beschikking te stellen. Door middel van een AMvB wordt het ARW 2012 als richtsnoer voorgeschreven voor werken onder de drempel. Daarvan afwijken mag alleen indien de aanbesteder daarvoor relevante argumenten heeft.

Een volgend in het oog springend element heeft betrekking op het splitsen danwel samenvoegen van opdrachten. Onder het BAO is er 
vooral aandacht voor 'de percelenregeling' die er op ziet dat opdrachten niet gesplist worden om onder de aanbestedingsplicht uit te komen (met het oog op de zogeheten drempelbedragen). In de nieuwe aanbestedingswet is er meer aandacht voor het splistsen van opdrachten (zodat мкв marktpartijen ook een kans maken) en op het 'verbod' op samenvoegen tenzij de opdrachtgever/aanbesteder daarvoor valide argumenten heeft.

Ook het informeren van 'verliezers' zal onder de nieuwe aanbestedingswet deugdelijker gemotiveerd plaats dienen te vinden ("een aanbestedende dienst dient alle inschrijvers de gunningsbeslissingen met relevante redenen mee"). Overigens wordt de bekende Alcatel termijn opgerekt van 15 naar 20 kalenderdagen. Dat geeft verliezende inschrijvers meer ruimte om bezwaar aan te tekenen; een indirecte manier om aanbesteders te 'dwingen' om de gunningsbeslissing goed te motiveren, om objectief en transparant te zijn in het hele proces.

\section{Concluderend:}

de veranderingen die de nieuwe Aanbestedingswet met zich meebrengt vormen geen beletsel voor het toepassen van pips. Eerder kan gesteld worden dat de nieuwe Aanbestedingswet zorgt voor een 'klimaat' dat beter past bij het Best Value gedachtegoed. Meer aandacht voor waarde (dus EMVI), vertrekken vanuit hetgeen het aan te besteden werk vraagt, open informatiedeling en meer kansen voor inschrijvers die wellicht niet de grootste zijn, maar wel op grond van hun specialismen de beste oplossing/aanbieding hebben. Beide zaken sluiten goed aan bij de PiPS methodiek: Pips laat kwaliteit dominant meewegen, en is gebaseerd op emvi als gunningscriterium (emvi is voorwaarde om pips te kunnen toepassen).Pips bevordert proportionaliteit doordat bij alle eisen uitgegaan wordt van wat het nu aan te besteden werk 'vraagt'.

\section{Brede toepassing van pips in Nederland sinds 2006}

$\mathrm{Na}$ de eerste 'pioniers' cases in 2005/2006 is pips in Nederland al enkele
${ }^{76}$ Scenter is een organisatieadviesbureau. Beide auteurs van het boek Prestatie Inkoop (vertaling van gedachtengoed van Kashiwagi) zijn werkzaam bij Scenter. genomen waarvoor veel belangstelling bestaat. Deelnemers aan dez meetings is gevraagd hun projecten toe te voegen aan een Database. Nog niet alle deelnemers hebben dat gedaan, en daarnaast zijn er ook toepassingen die buiten het bereik van deze early adaptors plaatsvinden. Deze Database bevat momenteel (begin november 2012) circa 150 projecten met een gezamenlijke waarde van minstens ${ }^{77} 1,6$ miljard euro. Het merendeel daarvan is door publieke opdrachtgevers aanbesteed. Rijkswaterstaat neemt het grootste deel voor haar rekening, maar ook gemeentes, waterschappen en andere bestuursorganen

hebben Pips/BVP ontdekt en toegepast. Onder private opdrachtgevers komen we onder andere onderwijsinstellingen, aannemers, vervoers bedrijven, woningcorporaties en zorginstellingen tegen. Tijdens de type A meetings komen verrassend weinig juridische issues aan de orde. Ook andere bronnen melden opvallend weinig over juridische procedures of 'kinken in de kabel' bij BVP toepassingen. Opdrachtgevers en opdrachtnemers (beiden zijn bij de type A meetings vertegenwoordigd) lijken er in te slagen tot wederzijdse tevredenheid 'Best Value' aan te besteden. Ik leid daar uit af dat aanbesteders in staat zijn aanbestedingsprocessen zo te ontwerpen en toe te passen dat de pips elementen op een verantwoorde wijze zijn in te passen. Ook in mijn eigen praktijk ( 15 aanbestedingen, in totaal ca. 90 miljoen euro aan omvang, zie Bijlage $\mathrm{x}$ ) blijkt dat in geen van de gevallen toepassing van pips heeft geleid tot juridische procedures.

\section{Concluderend:}

Zoals in dit hoofdstuk uiteengezet zijn er vanuit de theorie gezien voldoende toepassingsmogelijkheden voor PiPs. De Nederlandse praktijk sinds 2005 onderschrijft dit theoretisch inzicht, zowel voor wat betreft publieke als voor private opdrachtgevers.

\section{Voortschrijdend inzicht in de pips methodiek:}

pips zelf is in de loop van de jaren ook geëvolueerd. Voorbeelden: RAP/RAVA, het niet uitwisselen van technische infromatie hetgeen in het begin vrij dogmatisch werd gepropageerd en inmiddels wel word toegelaten, en ook het relatieve belang van Past Performance is in
77 Projecten waarbij geen waarde staat vermeld, zijn voor nul euro meegeteld. meetings waarbij functionarissen die pips toepassen tweemaal per jaar samen met Kashiwagi bijeen komen om ervaringen te delen. Vanuit dit initiatief wordt ook gewerkt aan certificering van PiPs/BVP consultants. NEVI heeft inmiddels een BVP module in haar assortiment op- 
Kashiwagi's betoog de laatste jaren geslonken. Ook de pre-award fase heeft zich ontwikkeld van een soort van pro forma stap waarin risicoverdeling wordt vastgesteld tot een stap die als functie heeft een inhoudelijke check uit te voeren met betrekking tot de vraag of de oplossing van de beoogd winnaar een passend en dekkend antwoord vormt op de vraag die de aanbesteder heeft gesteld. Ultieme consequentie van deze stap kan zijn dat de oplossing van de aanbieder tekort schiet en dat de aanbesteder niet met deze aanbieder in zee gaat (maar zijn aanbesteding afbreekt, of met de nummer twee in gesprek gaat). Ook kan deze stap tot gevolg hebben dat de aanbieder zijn oplossing licht aanpast waardoor deze wel het passende en dekkende antwoord zal vormen.

Hierin zit mogelijk echter een juridisch knelpunt. Inschrijvers moeten immers een onvoorwaardelijke inschrijving doen. Vlak voor het voornemen tot gunning de aanbieding wijzigen staat daarmee op gespannen voet. Afvallers kunnen zich hierdoor ook tekort gedaan voelen, omdat ze eventueel bereid kunnen zijn ook deze bijstellingen (of misschien zelfs nog meer) te doen. Kortom een zeker risico van zondigen tegen het gelijkheidsbeginsel ligt hier op de loer.

Vanuit de praktijk geredeneerd is het echter voor de hand liggend deze check uit te willen voeren. De aanbesteder heeft immers een vraag gesteld met een behoorlijke mate van oplossingsvrijheid; voor gunning willen weten wat je dan precies 'krijgt' voor je budget is dan een normale en legitieme wens. Deze check voor gunning kan namelijk 'gedoe' na gunning voorkomen, want het moment waarop concreet gesproken zal worden over te verwerken materialen/componenten (en de impact die dat heeft op uitstraling, gebruikswaarde, onderhoudskosten) komt toch een keer aan de orde.

Vooralsnog hanteer ik bij nieuwe aanbestedingen deze opgewaardeerde rol voor de pre-award fase waarbij ik bewaak dat de uitvraag niet wezenlijk gewijzigd wordt (de aanbesteder mag in deze fase niet ineens zwaardere outputspecificaties hanteren) en eventuele bijstellingen vallen onder de categorie 'of gelijkwaardig' danwel een precisering, verdere concretisering bevatten. Op die wijze blijven aanpassingen 'marginaal' en komen we niet terecht in een situatie waarin in deze laatste fase 'koehandel' plaats vindt.

\section{Concluderend:}

strikt vanuit juridische optiek gezien is er vervolgonderzoek nodig naar de juridische mogelijkheden om deze opgewaardeerde rol voor de pre-award fase in de aanbestedingspraktijk toe te passen. In de praktijk vullen we deze opgewaardeerde rol 'voorzichtig' in. 


\section{de toepassing van pips bij praktijk- \\ cases}

5.0 Inleiding

Na de inleidende en theorievormende hoofdstukken volgt nu een hoofdstuk waarin praktijkcases (meervoud, want er is gekozen voor multiple case study selection) centraal staan. Kern van dit hoofdstuk wordt gevormd door de vraag in hoeverre het theoretisch model zoals

beschreven in hoofdstuk drie bij toepassing van pips in de praktijk actief is. Dit hoofdstuk start met een inleidende methodologische paragraaf waarna de praktijkcases behandeld worden. Afgesloten wordt met een cross case analyse en met conclusies die getrokken kunnen worden naar aanleiding van de praktijktoepassingen. 


\section{De vier criteria van Yin}

Volgens Yin (2008) zijn case studies met name geschikt voor het bestuderen van innovatieve projecten. Het feit dat de onderzoeker deel uit maakt van zo een praktijkcase (zoals in dit onderzoek ook het geval is) biedt volgens Yin juist extra kansen om waardevolle waarnemingen (on site observations) te doen. Wel moeten de feiten voor zich blijven spreken en moet gewaarborgd worden dat daarmee integer om wordt gegaan. Uit de case beschrijvingen zal blijken dat aan die voorwaarden is voldaan. Het nieuwe fenomeen (pips) onderzoeken in een real life context biedt volgens Yin voordelen ten opzichte van andere onderzoeksstrategieën. De uitgevoerde praktijktoepassingen bieden aldus toetsingsmogelijkheden voor het theoretisch model.

Yin heeft tevens enkele critera ontwikkeld aan de hand waarvan vastgesteld kan worden of case studies tot 'goed onderzoek' leiden. Als eerste noemt hij construct validiteit. Daarmee wordt bedoeld dat het onderzoeksconstruct solide moet zijn. Het gebruik van meerdere bronnen en het bouwen aan een keten van bewijs zijn de tactieken die daarbij aanbevolen worden. Hieraan is tegemoet gekomen doordat telkens meerdere beoordelaars scores hebben gegeven en evaluatief zowel de inbreng van de opdrachtgever, de leden van het kernteam en ook de deelnemende opdrachtnemers is meegenomen. Aan de keten van bewijs is gebouwd door systematisch in alle praktijkcases de effecten van de pips safeguards op het reduceren van onzekerheid, het ontmoedigen van de neiging tot het vertonen van opportunistisch gedrag en het rekening houden met begrensde rationaliteit op de zelfde wijze te bestuderen (pattern matching als middel om de interne validiteit, het tweede Yin criterium, te vergroten). Daarnaast is door midel van een cross case analyse gezocht naar overeenkomsten in patronen, waarmee aandacht is besteed aan de externe validiteit (het derde Yin criterium). Tot slot is er het vierde Yin criterium: betrouwbaarheid. Yin beveelt aan een protocol per case study op te stellen en te hanteren en de uitkomsten van de casestudies in een database vast te leggen. Daarmee wordt de reconstrueerbaarheid vergroot. Bij de praktijkcases is daaraan invulling gegeven door een selectieleidraad op te stellen waarin het proces, de stappen, de beoordelingscriteria, de wegingsfactoren, de planning etc. vast te leggen. Daarnaast zijn notulen, verslagen, scorematrici vastgelegd en beschikbaar. Het verloop van de cases is daarmee gedocumenteerd. Bij enkele cases heeft een student uitgebreide logboeken bijgehouden aan de hand waarvan het verloop van de processen tot in detail kan worden gevolgd.

\subsubsection{Systematiek van case beschrijvingen}

Wijze van data verzameling:

Per praktijkcase is een beoordelingscommissie samengesteld. De leden van die commissie hebben beoordelingsformulieren per pips element ingevuld. Deze beoordelingsformulieren bevatten een beoordelingsinstructie en uiteraard waren daarin alle te beoordelen (sub)elementen opgenomen. Uiteindelijk is gerekend met het rekenkundig gemiddelde van deze beoordelingscommissie.

\section{Toe te passen safeguards per praktijkcase:}

Bij de vier praktijkcases is per case bekeken welke safeguards toepasbaar konden zijn rekening houdend met:

- Het stadium waarin het project zich bevond (starten vanuit een 'groene wei' situatie of springen op een 'rijdende trein');

- Wenselijkheid vanuit het project. Bij fase III UMC St Radboud was het bijvoorbeeld een bewuste keus van de opdrachtgever op basis van een uitgewerkt bestek aan te willen besteden. Bij de vier cases wordt hier kort verder op ingegaan;

- Omdat de auteur van dit proefschrift enkel betrokken was bij de aanbesteding en er geen gelegenheid was de uitvoering van de projecten intensief te volgen, zijn de pips safeguards uit de control fase niet beschreven.

Bepaling van de bijdrage van pips safeguards aan NIE mechanismen De bepaling van de bijdragen van de pips safeguards aan de NIE mechanismen (rekening houden met begrensde rationaliteit, geredu- 
ceerde onzekerheid en ontmoedigde neiging tot het vertonen van opportunistisch gedrag) heeft niet op kwantitatieve basis plaatsgevonden. Per case is door middel van interviews met de projectleider aan opdrachtgevers en opdrachtnemerszijde kwalitatief vastgesteld of en in welke mate de safeguards effecten opleverden.

\section{Reflectie aan de hand van leerpunten}

De beschrijving van de praktijkcases wordt afgesloten met leerpunten en deelconclusies. Om leerpunten te destilleren, wordt kort op alle cases vanuit onderstaande invalshoeken gereflecteerd:

- Geschiktheid project: deze invalshoek is van belang vanuit de vooronderstelling dat niet alle projecten geschikt zijn. Welke factoren spelen een rol van betekenis als het gaat om de vraag of een project geschikt is voor de $B V P$ aanpak?

- Ontleren en omdenken: deze invalshoek is van belang vanuit de vooronderstelling dat het loslaten van vertrouwde werkwijzen en het toepassen van nieuwe werkwijzen niet 'vanzelf' gaat. Wat zijn de succesfactoren in dit kader?

- Effectiviteit pips: deze invalshoek ligt voor de hand; doel is immers de cases als toets te gebruiken voor de werking van het theoretisch model. In welke mate doen de NIE mechanismen hun werk als gevolg van het toepassen van pips safeguards?

- Coöperatief versus competitief: deze invalshoek betreft een verbijzondering van de pips effectiviteit en ziet vooral op gedrag, houding, opstelling na gunning. In welke mate leidt het toepassen van pips safeguards daadwerkelijk tot ander gedrag, betere samenwerking, soepeler opstelling?

- Objectiviteit en transparantie: deze invalshoek is van belang vanuit het juridisch kader. Verloopt een pips aanbesteding in voldoende mate transparant en is er sprake van een voldoende mate van objectivering?

\subsection{De Onderhoudsprojecten UMC St Radboud}

Deze drie projecten zijn in 2005 als 'proeftuin' gekozen voor de integrale toepassing van pips.

\section{Aanleiding en wijze van dataverzameling}

De directeur van het Huisvestingsbedrijf (Felix van Baal) van het UMC St Radboud heeft dit pips onderzoek geïnitieerd; Hij had op grond van zijn jarenlange ervaring met de traditionele aanpak behoefte aan een andere aanpak. Na een globale kennismaking met het gedachtengoed van Kashiwagi, heeft hij de auteur van dit proefschrift gevraagd de methodiek nader te onderzoeken op effecten en toepasbaarheid. In dat kader waren testcases erg welkom.

Toen de mogelijkheid zich voordeed de drie onderhoudsprojecten PiPS wise aan te besteden en die aanbestedingen te begeleiden, is dat als kan gezien om eerste ervaringen op te doen. Deze drie onderhoudsprojecten zijn door de manager Onderhoud van het UMC St Radboud gekozen omdat elk van de drie onderhoudsdisciplines aan bod kwam, de

projecten niet te groot waren, en ze op de planning stonden van het lopende jaarplan.

Achteraf bleken de projecten (te) klein, bood het Bouwkundige project weinig uitdaging en was het Elektrotechnische project minder geschik vanwege de intensieve interactie (met de zorg) die nodig was om de werkzaamheden tot een goed einde te brengen. Die interactie wilde UMC St Radboud zelf invullen en regisseren, daardoor was er niet echt sprake van een leverancier die het werk naar eigen inzicht kon organiseren.

Scores zijn tot stand gekomen door de leden van een beoordelingscommissie individueel te laten beoordelen. Gerekend is met het rekenkundig gemiddelde van die individuele scores. Van alle scores en daarmee uitgevoerde berekeningen zijn Excel files (alsmede originele beoordelingsformulieren) beschikbaar.

Tijdens deze projecten heeft een student alle bijeenkomsten bijgewoond, een chronologisch logboek tot in detail bijgehouden en heeft zij zorg gedragen voor het verwerken van de scores van de individuele beoordelaars. Deze data is beschikbaar. Na afloop heeft een evaluatief gesprek plaatsgevonden met de manager onderhoud (ook daarvan is verslag- 


\section{legging beschikbaar)}

\section{Korte projectintroductie}

De eerste pips projecten bestonden uit drie kleine onderhoudsprojecten van de respectievelijke disciplines, Electro (herbekabelen van hoofdverdeelkasten), Werktuigbouw (vernieuwen van stoombevochtigingsinstallatie in bestaande luchtbehandelingssystemen) en Bouwkunde

(vervanging van compleet dakbedekkingspakket van een plat dak van ca. $800 \mathrm{~m}^{2}$ ). De totale omvang bedroeg circa 300.000 ,- inclusief BTW. Het betroffen reguliere projecten die voor 2005 op de planning stonden van het onderhoudsbedrijf van UMC St Radboud. Het management wilde 'klein beginnen' en heeft bewust voor deze mix van projecten gekozen zodat de verschillende onderhoudsdisciplines kennis konden maken met deze wijze van aanbesteden.

Bij deze projecten toegepaste safeguards:

\section{Funcspec De projecten zijn aanbesteed op basis van een functioneel} gespecificeerde projectscope. Er is veel vrijheid geboden bij het ontwikkelen van een oplossing die past bij de vraag. Er zijn enkel outputspecificaties meegegeven.

Budginf Het maximaal te besteden budget is vooraf aan marktpartijen bekend gemaakt. Deze maximale inschrijfsom is door alle partijen gerespecteerd; binnen dit financiële kader zijn adequate oplossingen ontwikkeld.

Marktpartijen hebben informatie ingeleverd over hun performance bij eerder gerealiseerde projecten. Hieruit 'sprak' een zekere mate van competent zijn voor wat betreft de succesvolle uitvoering van de nu aan te besteden werkzaamheden.

Marktpartijen is gevraagd naar risico's en bijbehorende remedies. Ook hebben marktpartijen de ruimte gehad optimalisatievoorstellen in te brengen. De kwaliteit van de RAVA plannen was sterk wisselend. Van 'griezelig' onvolledig en vooral non informatief, tot gedegen uitwerking, reële risico indicaties en vertrouwenwekkende remedies.

Qsleutelf De sleutelfunctionarissen zijn geinterviewd; interview resultaten hebben meegewogen bij deze aanbestedingen. Vanwege het niet beschikbaar hebben van een kundige projectleider heeft er zelfselectie plaatsgevonden, hetgeen onzekerheid heeft gereduceerd.

$\operatorname{Pr} /$ kwal Kwaliteit heeft voor $70 \%$ meegewogen; prijs voor $30 \%$ Dankzij deze verdeling konden leveranciers onderscheidend vermogen in de kwaliteit van de oplossing aanbrengen die ook van doorslaggevende invloed op win kansen kon zijn.

Tabel 5.1; Safeguards en hun effecten bij UMC St Radboud onderhoudsprojecten

In de tabel op de volgende pagina is te zien in welke mate de pips safeguards invloed hebben gehad op het reduceren van onzekerheid, het ontmoedigen van de neiging tot het vertonen van opportunistisch gedrag en het omgaan met begrensde rationaliteit van actoren. De weergaves zijn gebaseerd op de hiervoor weergegeven beschrijvingen van deze praktijkcase. 


\begin{tabular}{|c|c|c|c|}
\hline $\begin{array}{l}\text { Onderhouds } \\
\text { projecten UMC } \\
\text { St Radboud }\end{array}$ & $\begin{array}{l}\text { Bijdrage aan } \\
\text { reduceren } \\
\text { onzekerheid }\end{array}$ & $\begin{array}{l}\text { Bijdrage aan het } \\
\text { ontmoedigen van } \\
\text { opportunistisch } \\
\text { gedrag }\end{array}$ & $\begin{array}{l}\text { Bijdrage aan het om- } \\
\text { gaan met begrensde } \\
\text { rationaliteit }\end{array}$ \\
\hline Funcspec & $\begin{array}{l}\text { Onwennig; alleen het } \\
\text { 'wat' beschrijven was } \\
\text { nieuw }\end{array}$ & $\begin{array}{l}\text { Gecontracteerde } \\
\text { partijen hebben van } \\
\text { hun oplossing een } \\
\text { succes gemaakt }\end{array}$ & $\begin{array}{l}\text { Compact gefomu- } \\
\text { leerde vraag gaf focus }\end{array}$ \\
\hline Budgetinf & $\begin{array}{l}\text { Geen ongeldige } \\
\text { inschrijvingen }\end{array}$ & $\begin{array}{l}\text { Door reële } \\
\text { 'plafonds' geen } \\
\text { opportunistisch } \\
\text { gedrag nodig }\end{array}$ & $\begin{array}{l}\text { Helder kader waar- } \\
\text { binnen oplossingen } \\
\text { uitgewerkt konden } \\
\text { worden }\end{array}$ \\
\hline PPI & $\begin{array}{l}\text { Zelfselectie door } \\
\text { minder ervaren partij }\end{array}$ & $\begin{array}{l}\text { Marktpartijen } \\
\text { hebben goede } \\
\text { reputatie niet } \\
\text { geschaad }\end{array}$ & $\begin{array}{l}\text { PPI bleek ondanks } \\
\text { 'primeur' goed en } \\
\text { efficiënt hanteerbaar }\end{array}$ \\
\hline RAVA & $\begin{array}{l}\text { Plannen boden veel } \\
\text { onderscheidend } \\
\text { vermogen }\end{array}$ & $\begin{array}{l}\text { Plannen maakte } \\
\text { risico attitude goed } \\
\text { helder }\end{array}$ & $\begin{array}{l}\text { Compacte plannen } \\
\text { waren goed en } \\
\text { efficient hanteerbaar }\end{array}$ \\
\hline Qsleutelf & $\begin{array}{l}\text { Grote verschillen. } \\
\text { Sleutelfunctionaris- } \\
\text { sen bleken inderdaad } \\
\text { competent }\end{array}$ & $\begin{array}{l}\text { Sleutelfunctionaris- } \\
\text { sen vertoonden } \\
\text { coöperatief gedrag }\end{array}$ & $\begin{array}{l}\text { Geen direct effect op } \\
\text { dit mechanisme }\end{array}$ \\
\hline Pr/kwal & $\begin{array}{l}\text { Gunnen op waarde } \\
\text { heeft geleid tot value } \\
\text { for money }\end{array}$ & $\begin{array}{l}\text { Constructieve } \\
\text { samenwerking, geen } \\
\text { oneingelijke } \\
\text { discussies }\end{array}$ & $\begin{array}{l}\text { Geen direct effect } \\
\text { op dit mechanisme }\end{array}$ \\
\hline
\end{tabular}

De mate waarin het theoretisch model actief was en dit leidde tot de verwachtte resultaten.

Mechanisme $\mathbf{1}$

TOEPASSING VAN PIPS ELEMENTEN REDUCEERT ONZEKERHEID. Beschikbare informatie over past performance, over de manier waarop partijen risico's denken te managen en over de competenties van projectleiders heeft ertoe bijgedragen dat partijen zijn gecontracteerd die in staat zijn gebleken de projecten volgens de regels der kunst tot een goed einde te brengen. Met andere woorden: het beschikbaar hebben van deze informatie heeft de voorspellende waarde van de aanbesteding vergroot en daarmee onzekerheid gereduceerd.

Mechanisme 2

TOEPASSING VAN PIPS ELEMENTEN REDUCEERT RUIMTE VOOR EN NEIGING TOT OPPORTUNISME.

Doordat het onderscheidend vermogen voor $70 \%$ kwaliteitgerelateerd was en slechts $30 \%$ prijsgerelateerd, konden marktpartijen een redelijke marge maken. Het feit dat de vraagspecificatie veel oplossingsruimte bood, maakte dat opdrachtnemers veel commitment met hun eigen oplossing/aanpak voelden en niet de neiging hadden zich te verschuilen achter de door anderen uitgewerkte oplossing. De vanuit de theoretische redeneringen veronderstelde effecten van deze twee aspecten (meer commitment en de gelegenheid een faire marge te kunnen realiseren) traden in de praktijk van deze pilotprojecten in duidelijk waarneembare mate op; er was sprake van coöperatief gedrag, gemaakte afspraken werden onverkort nagekomen.

Tabel 5.2; invloed safeguards op NIE mechanismen bij UMC St Radboud onderhoudsprojecten 


\section{TOEPASSING VAN PIPS ELEMENTEN DRAAGT BIJ AAN HET} OMGAAN MET BEGRENSDE RATIONALITEIT

Het vertalen van ingeleverde PPI, RAVA's, interviewresultaten en plannen naar countable figures (aan de hand van van te voren vastgestelde

criteria, normen en rekenregels) maakte de informatie beter hanteerbaar en objectiever vergelijkbaar. De focus op deze essentiele informatie is door betrokkenen als prettig en goed werkbaar ervaren.

\section{Leerpunten en deelconclusies}

\section{Geschiktheid project}

De geselecteerde projecten waren achteraf bezien niet echt geschikt. Ze waren erg klein in verhouding tot de te doorlopen stappen in de pips procedure en de daarmee gepaard gaande tijdsbesteding aan opdrachtgevers en opdrachtnemers zijde (leverde naar verhouding hoge transactiekosten op aan beide zijden). Dit geldt zelfs wanneer de bestede tijd die samenhangt met het feit dat pips nieuw was, buiten beschouwing gelaten wordt. De $\mathrm{E}$ en $\mathrm{w}$ projecten vroegen daarnaas een behoorlijke mate van interactie met klantgroepen. Omdat UMC St Radboud deze afstemmingen zelf in wilde vullen, was risk transfer naar de installateurs toe maar deels mogelijk en konden deze installateurs niet autonoom performen. Het в project was te eenvoudig (geen uitdaging; commodity met voor de hand liggende oplossing).

\section{Ontleren en omdenken}

Best Value Procurement toepassen in een organisatie die een historie heeft in traditioneel aanbesteden valt niet te onderschatten. Het

formuleren van een oplossingsvrije vraagspecificatie, het maken van onderscheid tussen informatie die je wel verstrekt (omdat die informatie gewoonweg nodig is voor een goed begrip van de vraag en de context waarbinnen de vraag gesteld wordt) en informatie die je niet verstrekt (omdat je benieuwd bent wat de visie van de inschrijver op dat punt is), zijn voorbeelden van zaken die 'omdenken' en 'ontleren' verlangen.

\section{Effectiviteit Pips}

Het voorspellend vermogen van de aanbestedingen is bevredigend gebleken. Projecten zijn binnen planning en budget en naar tevredenheid (van opdrachtgever en opdrachtnemer) opgeleverd. Partijen bleken competent te zijn met betrekking tot de te verrichten zaken en hebben aan de verwachtingen van de opdrachtgever voldaan. Partijen die niet in de positie waren een concurrerend voorstel in te leveren, zagen zelf van deelname af. pips bevordert hiermee zelf selectie. Ter illustratie een quote van een van de pratijen die zichzelf terugtrok:

"Met zeer veel belangstelling hebben we kennis genomen van de nieuwe manier van aanbesteden volgens de PiPs methodiek. De uiteenzetting op 25 oktober was helder en duidelijk. Het is goed om vast te stellen dat er belangrijkere selectiecriteria bestaan dan alleen de prijs. Met betrekking tot het eerste pilotproject: stoombevochtiging, moeten we u helaas mededelen dat $\mathrm{XX}$ over onvoldoende ervaring beschikt met betrekking tot stoom- en condensleidingen en stoombevochtiging in haar algemeenheid om door de eerste selectiecriteria te kunnen komen."

\section{Coöperatief versus competitief}

Aannemers hebben geen gedrag vertoond dat de belangen van de opdrachtgever heeft geschaad. Zo zijn er geen 'oneigenlijke meerwerk discussies' gevoerd maar is er juist met de opdrachtgever meegedacht. Er is goed samengewerkt. De sfeer was coöperatief en vertoonde geen kenmerken van een traditionele 'conflictcultuur'. Aannemers stelden zich coulant en flexibel op. Er was duidelijk sprake van alignment of goals en daarop gebaseerde coöperatieve opstelling.

\section{Objectiviteit en transparantie}

Het beoordelen en toekennen van scores conform de vooraf uitgewerkte en gecommuniceerde structuur heeft geleid tot transparantie en geobjectiveerde en goed onderbouwde keuzes. Het standaardiseren van de interviews, het vooraf bepalen van wegingsfactoren en rekenregels en het 'constante' interview team hebben bijgedragen tot geobjectiveerde beoordeling van interviews. PPI opvragen met behulp van checklists verloopt stroef. "We hebben toch al een tevredenheidsverklaring herlegd!?" Ook de inschrijvers gaven aan dat deze wijze van PPI 
verzamelen omslachtig en tijdrovend heeft gewerkt. Ook vreesden enkele inschrijvers dat collega inschrijvers de checklists zelf ingevuld hadden, en deze vervolgens door hun voormalig opdrachtgevers hebben

${ }^{78}$ De juridische bezwaren ten aanzien van objectiviteit (zie hoofdstuk vier) bleken bij deze praktijkcase niet ongegrond. laten ondertekenen ${ }^{78}$. Het hanteren van relatieve scores bij de onderhoudsprojecten voor de aspecten PPI en prijs verdient niet de voorkeur. Bij aanbestedingen moeten deze relatieve scores zoveel mogelijk worden vermeden (zie hoofdstuk vier). De score van een partij, mag immers niet afhankelijk zijn van die van een andere partij (gelijke kansen bieden).

\section{Juridische rechtmatigheid}

Er is weinig expliciete aandacht besteed aan de juridische rechtmatigheid van deze aanbestedingen en de vertaling daarvan naar een formele aanbestedingsprocedure. Dit vindt zijn oorzaak in het feit dat de onderhoudsprojecten ver beneden de drempelbedragen voor werken lagen. De aanbestedingsbeginselen (objectiviteit, transparantie en non-discriminatie) hebben wel op de achtergrond meegespeeld bij het inrichten van de aanbestedingsprocessen. Er zijn door deelnemers geen protesten geuit en er hebben zich geen geschillen voorgedaan.

\section{Overige pilot leerpunten}

De selectieleidraad moet nog eenduidiger zijn voor wat betreft in te dienen stukken en daarbij geldende (werk)afspraken zodat bijvoorbeeld uitsluitend anonieme RAVA's ingeleverd worden, inlevermomenten en het gecommuniceerde budgetplafond strikt gehanteerd kunnen worden.

\section{Samenvattend:}

Het toepassen van de genoemde safeguards heeft geleid tot een reductie van onzekerheid, ontmoediging van de neiging tot opportunistisch gedrag en tot oplevering binnen budget en planning waarbij aan de verwachtingen van de opdrachtgever is voldaan. De matige geschiktheid van deze projecten in combinatie met de weinig methodische keuze van deze projecten vormen methodologische kwetsbaarheden. Anderzijds hebben deze 'spannende' eerste projecten wel bijgedragen tot meer inzicht in de PiPs methodiek.

\subsection{Nieuwbouw Parkeergarage UMC St Radboud}

Aanleiding en wijze van dataverzameling

Op basis van de positieve ervaringen met de pips aanpak bij de drie onderhoudsprojecten, heeft UMC St Radboud ervoor gekozen een aantal pips elementen in te brengen bij de (reeds in voorbereiding zijnde) aanbesteding van de nieuwbouw van een parkeergarage. Vanuit mijn onderzoeksoptiek was dit een welkome kans. De omvang van het project was duidelijk geschikter dan de eerste drie cases en de bouw van een parkeergarage is goed vanaf enige afstand te managen (minder intensieve interactie met 'de zorg'). Daarmee leek dit project een meer geschikte testcase dan de eerste onderhoudsprojecten die hiervoor uiteengezet zijn.

Scores zijn tot stand gekomen door de leden van een beoordelingscommissie individueel te laten beoordelen. Gerekend is met het rekenkundig gemiddelde van die individuele scores. Van alle scores en daarmee uitgevoerde berekeningen zijn Excel files (alsmede originele beoordelingsformulieren) beschikbaar.

Door de UMC St Radboud projectleider zijn van alle meetings verslagen gemaakt. Van het evaluatiegesprek met de projectleider is tevens een verslag beschikbaar. Kortom een compleet dossier over deze aanbesteding (inhoud en proces) is beschikbaar.

Als methodologische kwetsbaarheid noem ik hier het feit dat PPI geen invloed heeft gehad op de samenstelling van de leveranciers die mee gingen dingen. Dat heeft alles te maken met het feit dat op het moment dat dit onderzoek in beeld kwam, de shortlist al bepaald was. Het wel toepassen van PPI als nader selectiecriterium was wellicht van invloed geweest op de uitkomst van deze aanbesteding.

\section{Korte projectintroductie:}

Het ontwikkelen en realiseren van een bovengrondse parkeervoorziening (een zogeheten stallingsgarage voor personeel), fase één, in de vorm van een turn-key project, met inachtneming van randvoorwaarden met betrekking tot:

- Minimale capaciteit (630 stallingsplaatsen ${ }^{79}$ )
${ }^{79}$ Capaciteit dient op termijn modulair uit te breiden te zijn naar 2000 parkeerplaatsen; vandaar dat wordt gesproken over fase één. 
- In- en uitrijden via bestaande wegen

- Perceelgrenzen en maximale bebouwingshoogte respecteren

- Modulaire en eenvoudig (naar 2000 parkeerplaatsen) uit te breiden opzet

- Aansluiten op UmC carré moet tot de mogelijkheden behoren

- Open gevels, zodat natuurlijke ventilatie volstaat

- Respecteren van maximaal geluidsniveau conform milieuvergunning uMC St Radboud

- Passend binnen stedenbouwkundige uitgangspunten UMC Campus

- Aanwezige NUON Inkoopstation handhaven binnen het voorstel

- Ondergrondse infrastructuur

- Mogelijkheden om fietsen te stallen

- Maximaal beschikbare budget van 4,2 miljoen euro.

Bij dit project toegepaste safeguards:

Funcspec Dit project is aanbesteed op basis van een functioneel gespecificeerde projectscope ("kom met een voorstel dat past op dit perceel, deze bebouwingsvoorschriften, dit budget, houd rekening met ondergrondse infrastructuur"). Op deze wijze is er maximale oplossingsvrijheid geboden hetgeen zich heeft vertaald in vele uiteenlopende oplossingen met elk hun eigen voor en nadelen. Met behulp van de vooraf geformuleerde beoordelingscriteria kon daaruit geobjectiveerd de beste oplossing worden geselecteerd.

Budginf Het maximaal te besteden budget is vooraf aan marktpartijen bekend gemaakt. Alle partijen hebben deze maximale inschrijfsom gerespecteerd. Uiteindelijk is gegund aan de marktpartij wiens oplossing $6 \%$ onder het maximale niveau lag.
Marktpartijen hebben tijdens de presentatie van hun oplossing informatie ingeleverd over eerder gerealiseerde projecten. De kwaliteit van de PPI vertoonde een ruime bandbreedte. Van honderden gebouwde garages (de winnende partij) tot slechts een of twee garages. De ervaren partij beschikte dankzij deze grote hoeveelheid projecten over een uitgekiende en meerdere malen geoptimaliseerde oplossing.

RAVA

Marktpartijen is gevraagd tijdens het presenteren van hun oplossing in te gaan op risico's en bijbehorende remedies. In het algemeen beperkte deze RAVA's zich tot algemene projectmanagement risico's.

Qsleutelf De sleutelfunctionarissen hebben de oplossing gepresenteerd; er zijn geen expliciete interviews gehouden. Deze safeguard leverde in het oog springende verschillen op tussen de aanbieders. De ene functionaris bleek het project van binnen en van buiten te kennen, terwijl de andere functionaris in oppervlakkigheden bleef steken.

$\mathrm{Pr} / \mathrm{kwal} \quad$ Kwaliteit heeft voor $70 \%$ meegewogen; prijs voor $30 \%$. Inschrijvers konden zichtbaar focussen op de kwaliteit van hun aanbieding.

Tabel 5.3; Safeguards en hun effecten bij UMC St Radboud parkeergarage

Zoals uit de beschrijving van toegepaste safeguards blijkt, zijn enkele elementen minder expliciet aan de orde geweest. De verklaring daarvoor is gelegen in het feit dat de koppeling tussen dit onderzoek en dit project tot stand kwam op het moment dat deze aanbesteding al in de startblokken stond.

In de tabel op de volgende pagina is te zien in welke mate de pips safeguards invloed hebben gehad op het reduceren van onzekerheid, het ontmoedigen van de neiging tot het vertonen van opportunistisch 
gedrag en het omgaan met begrensde rationaliteit van actoren. De weergaves zijn gebaseerd op de hiervoor weergegeven beschrijvingen van deze praktijkcase.

\section{Parkeergarage Bijdrage aan uMC St Radboud reduceren} onzekerheid

Funcspec

Geen twijfel over de wat' vraag.

Budgetinf

Plafond bleek reëel, te dure oplossingen werden ter zijde gelegd

Er is een ervaren partij gecontracteerd. Vaardigheid en routine kwam in de uitvoering goed uit de verf

RAVA

Zich voordoende risico's konden goed worden getackeld dankzij RAVA

Qsleutelf

Grote verschillen; gecontracteerde partij zette prima team in
Bijdrage aan het ontmoedigen van

opportunistisch gedrag

Verschillen in oplossingen leidde tot onderscheidend vermogen. Wil om hun oplossing tot succes te maken was merkbaar

\section{Mede door reëel} plafond, geen opportunistisch gedrag

Goede reputatie is waargemaakt; niet tornen aan afspraken, verantwoordelijkheid pakken

Geen direct effect op dit mechanisme

Sleutelfunctionarissen getuigden van BVP mindset niet separaat beoordeeld

Bijdrage aan het omgaan met begrensde rationaliteit

Functionele specificatie was achteraf bezien misschien iets te krap

Helder kader voor alle betrokkenen

PPI is niet separaat verzameld

Geen direct effect op dit mechanisme
Pr/kwal

Geen budget onzekerheid, geen

Opportunistisch twijfel over kwaliteit gedrag was 'niet van het werk
Geen direct effect op dit mechanisme

Tabel 5.4; invloed safeguards op NIE mechanismen bij UMC St Radboud parkeergarage

De mate waarin het theoretisch model actief was en dit leidde tot de verwachtte resultaten

Mechanisme

TOEPASSING VAN PIPS ELEMENTEN REDUCEERT ONZEKERHEID, De gevolgde aanpak heeft geleid tot het verkleinen van onzekerheid. De geselecteerde partij heeft immers al enkele honderden vergelijkbare garages gebouwd en heeft zich bovendien goed verdiept in de specifieke situatie. Het uitgewerkte voorstel getuigt van visie, ervaring en inzicht. Zowel transactieonzekerheid (zal de opdrachtnemer wel in overeenstemming met de gemaakte afspraken performen?), marktonzekerheid (selecteer ik wel een adequate partij die een adequaat aanbod neerlegt?) en behoefteonzekerheid (kopen we wel het juiste, wat we nodig hebben?) zijn door de pips aanpak gereduceerd.

Mechanisme 2

TOEPASSING VAN PIPS ELEMENTEN REDUCEERT RUIMTE VOOR EN NEIGING TOT OPPORTUNISME.

Ook hier heeft de focus op 'waarde' (in plaats van dat prijs de meest dominante factor is) onderscheidend vermogen opgeleverd op het gebied van kwaliteit gerelateerde aspecten. Er is bij dit project geen sprake van 'de-laagste-prijsklem'; inschrijvers hebben daardoor de ruimte gekregen de aanbesteding te winnen op basis van de beste 
oplossing tegen een faire prijs. Daarnaast heeft ook het feit dat aannemers hun eigen oplossingen konden aandragen een positief effect gehad op het commitment dat tijdens de realisatie aan de dag werd gelegd. Tot slot heeft de ruimte die de aannemer is geboden om zijn oplossing te realiseren op zijn manier ertoe bijgedragen dat er geen opportunistisch gedrag heeft plaatsgevonden. De opstelling en houding waren eerder flexibel en coulant; de opdrachtnemer had zelf immers belang bij efficiënt en foutloos werk. Over de afgesproken fixed price is geen moment discussie geweest. Ook is er geen sprake geweest van meerwerk, dat niet door de opdrachtgever is geïnitieerd.

Mechanisme 3

TOEPASSING VAN PIPS ELEMENTEN DRAAGT BIJ AAN HET OMGAAN MET BEGRENSDE RATIONALITEIT.

Door de focus op informatie die tot onderscheidend vermogen leidde en door de vooraf vastgestelde beoordelingsstructuur en bijbehorende rekenregels, is het aanbestedingsproces effectief en efficiënt verlopen. Ook na gunning is het projectmanagement opvallend efficiënt ingevuld. Risico's zijn daar gelegd waar ze het beste gedragen konden worden en het project is vanaf een zekere afstand gemanaged. Het vertalen van ingeleverde plannen naar countable figures (aan de hand van van te voren vastgestelde criteria, normen en rekenregels) maakte de informatie beter hanteerbaar en objectiever vergelijkbaar. Daardoor verkleint pips de consequenties van begrensde rationaliteit hetgeen zich manifesteert als geringere onzekerheid.

\section{Leerpunten en deelconclusies}

\section{Geschiktheid project}

De aanbesteding van deze garage bleek een geschikt project om toepassing en werking van een aantal PiPS elementen in de praktijk te testen. Het project bevatte voldoende uitdaging, de vraagspecificatie bood voldoende oplossingsvrijheid, het project was door UMC St Radboud goed vanuit een zekere distantie te managen (parkeervoorzieningen raken de core business niet direct en de bouw van de garage is goed als solitair project te managen). Ook de omvang van het project was passend bij de gehanteerde werkwijze: het project had voldoende body en bevond zich onder de Europese drempel.

\section{Ontleren en omdenken}

Het projectteam wilde van meet af aan dat oplossingen vanuit de markt aangedragen zouden worden. Daardoor heeft 'ontleren en omdenken' een minder prominente rol vervuld dan bij de aanbesteding van de onderhoudsprojecten het geval was. Wel was er tijdens de concretisering van het geselecteerde ontwerp en tijdens de bouw vanuit Service \& Onderhoud de neiging extra wensen te formuleren en bepaalde details voor te schrijven.

\section{Effectiviteit Pips}

Ondanks budgetoverschrijding als gevolg van extra wensen/eisen en duurdere fundatie, is een zeer kostenefficiënte parkeerfaciliteit gerealiseerd. De uiteindelijke kosten per parkeerplaats liggen duidelijk onder het gemiddelde van de bandbreedte in de markt. Wat het waarde aspect betreft kan achteraf gesteld worden dat een hoogwaardige parkeervoorziening is gerealiseerd die voldoet aan de uitgangspunten (stedenbouwkundige inpassing, comfortabel parkeren, sociale veiligheid, verlichtingsniveau). De gerealiseerde oplossing vraagt weinig onderhoud (materiaalkeuze) en is uitgerust met energiezuinige verlichting. Het project is binnen planning en budget (behoudens de aannemer niet toe te rekenen zaken) en naar tevredenheid opgeleverd.

\section{Coöperatief versus competitie}

De samenwerking tussen opdrachtgever en opdrachtnemer is plezierig, professioneel en coöperatief verlopen. De opdrachtnemer heeft geen pogingen gedaan te tornen aan gemaakte afspraken, is coulant gewees en heeft een flexibele opstelling gehanteerd. Ter illustratie; omdat bij het storten van enkele vloeren de weersomstandigheden niet optimaal waren, zag het oppervlak er niet erg strak uit. Een coating was alleen voor de bovenste (dak)vloer overeengekomen. De opdrachtnemer heeft voor eigen rekening en op eigen initiatief de coating op alle vloeren aangebracht. Ook is de Fixed price gestand gedaan. Zo heeft de opdrachtnemer een vaste prijs voor staal afgegeven en die voor zes 
maanden gestand gedaan. De staalprijs is sindsdien substantieel gestegen. Dat heeft echter nooit tot discussies geleid. De Opdrachtnemer verwoordt in "good practise cahier 3 " van het Bouwcollege zijn ervaring met deze innovatieve aanbesteding als volgt:

"De bedoeling achter deze wijze van aanbesteden is evident. De door het UMC St Radboud gekozen wijze van aanbesteden biedt, binnen de gestelde kaders, ruimte voor creativiteit en vindingrijkheid van de aanbieders. Mede dankzij het stellen van een investeringsplafond, is duidelijk wat de opdrachtgever verwacht van het te realiseren object en kan men zich concentreren op maximale kwaliteit, binnen het aanwezige budget. Een innovatieve wijze van aanbesteden, waarop wij bij herhaling graag weer onze aandacht zullen richten."

\section{Objectiviteit en transparantie}

Het door een team laten beoordelen aan de hand van heldere criteria met duidelijke wegingsfactoren heeft gezorgd voor objectivering. Deze geobjectveerde beoordelingen zijn teruggekoppeld op een geanonimiseerde wijze. Er zijn door inschrijvers geen protesten geuit en geschillen hebben zich niet voorgedaan.

\section{Juridische rechtmatigheid}

UMC St Radboud heeft gebruik gemaakt van de vrijheid de procedure naar eigen inzicht in te richten (er bestond immers geen verplichting een van de formele procedures te hanteren). Objectiviteit, transparantie en non discriminatie hebben hierbij wel de nodige aandacht gehad.

\section{Terugblik opdrachtgever}

De opdrachtgever is tevens positief over de toegepaste innovatieve wijze van aanbesteden en de daarbij gehanteerde contractvorm. Toepassing hiervan bij toekomstige projecten die kunnen volstaan met een terughoudende rol van de opdrachtgever (denk daarbij aan kantoren, magazijnen, archieven) ligt in de lijn der verwachting ${ }^{80}$. Wel zal bij toekomstige projecten de vraagspecificatie iets verder uitgewerkt worden zodat minder 'open eindjes' in de contracteringsfase resteren. Denk hierbij bijvoorbeeld aan het verstrekken van meer informatie over de ondergrondse infrastructuur en de draagkracht van de bodem.

\section{Overige items}

De voorbereidings- en selectiefase is bij de parkeergarage efficiënt verlopen, zowel aan opdrachtgevers zijde als aan de zijde van marktpartijen. Tussen selectie en contractering is er door opdrachtgever én opdrachtnemer veel tijd besteed aan het ophelderen van nog openstaande zaken, het completeren van nog ontbrekende informatie, die wel wezenlijk bleek om tot een werkbaar contract te komen, en het verder engineeren van de aangeboden oplossing. Tijdens de bouw van de parkeergarage is de managementcapaciteit aan de zijde van de opdrachtgever toch aanzienlijk geweest. Dat is echter voornamelijk terug te voeren op de extra wensen die vanuit de gebruikers en de beheersorganisatie werden gesteld. Bij het realiseren van de oorspronkelijk overeengekomen parkeerfaciliteit is de opdrachtnemer zeer zelfstandig te werk gegaan en heeft de opdrachtgever minimale bemoeienis gehad. Alles wijst erop dat wanneer bij het voortraject goede en complete informatie over de bodem (infrastructuur en draagkracht) was verstrekt, en de wensen van de gebruikers en de beheerder van meet af aan in de projectscope waren ingebouwd, dit geleid zou hebben tot een aanzienlijke reductie van benodigde managementcapaciteit aan de zijde van de opdrachtgever. De conclusie is dan ook dat bij een goede projectvoorbereiding bij dit type projecten een substantiële vermindering van benodigde managementcapaciteit te verwachten is.

\section{Samenvattend:}

De toepassing van de beschreven safeguards heeft geleid tot reductie van onzekerheid en tot coöperatief gedrag aan de zijde van de aannemer. Het project is tijdig en zonder meerwerk dat de aannemer is toe te rekenen, naar tevredenheid opgeleverd.

\subsection{Nieuwbouw Fase III UMC St Radboud}

\section{Aanleiding en wijze van dataverzameling}

Deze casus was interessant voor dit onderzoek vanwege de specifieke vraag omtrent PPI. Bij de onderhoudsprojecten bestond er 'in de markt' weerstand tegen de 'Kashiwagi aanpak'. Bovendien zijn er vanuit juridische optiek bezwaren tegen de Kashiwagi aanpak met het oog 
op objectiviteit. Daarnaast was er behoefte aan PPI die informatief zou zijn voor de nu aan te besteden 'uitdaging'. Zodoende is er in het kader van dit project een alternatieve PPI werkwijze ontwikkeld die in de praktijk van de verdere pips aanbestedingen van grote waarde blijkt te zijn.

Scores zijn tot stand gekomen door de leden van een beoordelingscommissie de ingevulde "vragenlijsten Prestaties uit het verleden" individueel te laten beoordelen. Gerekend is met het rekenkundig gemiddelde van die individuele scores. Van alle scores en daarmee uitgevoerde berekeningen zijn Excel files (alsmede originele beoordelingsformulieren) beschikbaar

De projectorganisatie die belast was met de aanbesteding van Fase III heeft van alle meetings verslagen gemaakt. Ook van de evaluatie die plaatsgevonden heeft is een verslag beschikbaar.

De methodologische kwetsbaarheid in deze casus wordt gevormd door het feit dat deze aanbesteding op twee gedachten is gebaseerd: enerzijds een technisch gespecificeerd bestek, anderzijds het toepassen van enkele pips elementen. Deze ambivalente aanpak kan vertroebelend werken voor wat betreft de werking van de innovatieve pips elementen. Daar staat tegenover dat dit risico defacto geen effect op de selectie heeft gehad vanwege het geringe aantal inschrijvers, waardoor er uiteindelijk maar één gegadigde overbleef aan wie is gegund.

\section{Korte projectintroductie}

Fase II omvat nieuwbouw ter grootte van ca. $67.500 \mathrm{~m}^{2}$ (bruto vloer oppervlak) en past in het meer omvattende masterplan dat sinds de jaren ' 90 in uitvoering is en dient te leiden tot vernieuwing en revitalisatie van de UMC St Radboud Campus. De te realiseren gebouwen zullen onder andere voorzien in poliklinieken, diagnostische centra, SEH (Spoed Eisende Hulp), een bestuurscentrum, heli landingsplaats, IC's, ondersteunende functies en verbindingsgangen met andere bouwdelen. Typerend voor deze bouwopgave is dat ze gerealiseerd moet worden terwijl de bedrijfsvoering van UMC St Radboud continue en ongehinderde en veilige doorgang moet kunnen hebben. Een bypass (tijdelijke verbindingsgang om de veilige bereikbaarheid van alle gebouwen te garanderen) maakt dan ook deel uit van het project. De aanbesteding bestaat uit drie losse percelen: B, E en w. De Bouwkundig aannemer krijgt de coördinatie taak en de $\mathrm{E}$ en $\mathrm{w}$ aannemers vervullen de rol van nevenaannemers.

Alleen de safeguards PPI en Budgetinf zijn bij dit project toegepast. Er was al een uitgewerkt bestek voorhanden en bovendien durfde men dit project niet veel oplossingsruimte te bieden; er is voor gekozen traditioneel aan te besteden, maar wel een maximale inschrijfsom te hanteren (dat heeft te maken met de actuele marktomstandigheden; die waren zodanig dat collega ziekenhuizen veel met ongeldige, lees te dure, inschrijvingen werden geconfronteerd). Ook PPI is bewust wel gehanteerd, zij het op een andere wijze dan bij de onderhoudsprojecten het geval was (zie verderop). PPI is gehanteerd als selectiecriterium in het kader van technische vakbekwaamheid. Marktpartijen dienden een

"Vragenlijst Prestaties uit het verleden" in te vullen van vier uitgevoerde en reeds opgeleverde projecten. Naast deze PPI telden ook de organisatie en kwaliteitsbewaking mee als criteria voor technische vakbekwaamheid.

\section{Verloop van de aanbesteding}

Bij deze aanbesteding is gekozen voor het besteksgereed op de markt zetten van de bouwopgave. Er was slechts in beperkte mate ruimte voor het toepassen van pips elementen. De voorbereidingen van deze aanbesteding waren al ver gevorderd op het moment dat dit pips onderzoek in beeld kwam. De juridische ins \& outs met betrekking tot het interviewen van sleutelfunctionarissen waren nog onvoldoende uitgekristalliseerd om bij deze Europese aanbesteding tegen een acceptabel risiconiveau uit te kunnen voeren. Daarnaast wilde men bij deze aanbesteding 'op safe spelen' vanwege eerdere ervaringen met juridische procedures en andere uitingen in de media die het UMC St Radboud imago raakten. Er is gekozen voor een niet openbare procedure conform de Europese Richtlijn (2004/18/EG) en het ARW 2005 is van toepassing. In de selectiefase worden maximaal acht geschikte gegadigden per perceel uitgekozen en uitgenodigd een inschrijving te doen. Naast uitsluitingsgronden en minimumeisen zijn facultatieve selectieeisen opgenomen. In de gunningsfase is EMVI (economisch meest voordelige inschrijving) als gunningscriterium gehanteerd. Er is een maximale inschrijfsom (ISmax) gecommuniceerd die niet overschreden mocht worden. 
Toepassing van Pips safeguards is in de selectiefase beperkt tot Past Performance Information en Budgetinf. Hierbij is niet de standaard Kashiwagi methodiek gehanteerd, maar is aan gegadigden gevraagd om van vier, binnen de laatste vijf jaar uitgevoerde en reeds opgeleverde relevante werken, op een verifieerbare wijze te beschrijven hoe met een aantal voor dit (nu aan te besteden) project karakteristieke items is omgegaan en waartoe dat heeft geleid. Hiervoor is gekozen vanwege het objectiviteitsbeginsel. Bij de 'Kashiwagi methode' kan de kwaliteit van de relatie van invloed zijn op de toegekende scores. Zodoende kan een vertekening plaatsvinden, zowel ten voordele als ten nadele van één of meerdere inschrijvers. Ook het beheersen van transactiekosten ligt ten grondslag aan deze keuze. Van zo veel mogelijk projecten PPI opleveren is immers belastend voor gegadigden, voormalig opdrachtgevers en de aanbesteder. Het laten beschrijven van de aanpak bij vier projecten impliceert een reductie van transactiekosten ten opzichte van de oorspronkelijke door Kashiwagi ontwikkelde methodiek.

Ook het feit dat deze aangepaste werkwijze meer informatie oplevert die van belang is om te kunnen beoordelen wat de mate van geschiktheid voor dit project is, is een overweging geweest in dit kader. Bij de 'Kashiwagi methode' wordt de link met de karakteristieken van het nu aan te besteden werk niet expliciet opgezocht ${ }^{81}$. Het begrip 'relevante werken' is hierbij als volgt geoperationaliseerd. Een werk is relevanter naarmate het meer overeenkomsten met onderstaande zaken vertoont:

- Omvang van het werk afgezet tegen de omvang van dit project

- Installatietechnische aspecten vormen een substantieel deel van het totale werk

- De bouwopgave is complex

- De bouwopgave speelt zich af in een krappe bebouwde omgeving waarbij de bedrijvigheid veilig en ongestoord doorgang kan vinden

- De opdrachtgever wenst pas 'last minute' definitieve specificaties vast te stellen

Voor het indienen van deze PPI is in de selectieleidraad een vragenlijst opgenomen die op de volgende pagina's wordt weergegeven: vraag 1 Projectkarakteristiek. Hierin dient u minstens te vermelden:

- Naam van het project

- Naam van de opdrachtgever (rechtspersoon)

- Naam van de directievoerder

- Naam, adres, telefoonnummer en e-mail adres van de contactpersonen aan de zijde van de opdrachtgever en directievoerder bij wie het UMC St Radboud deze informatie over prestaties uit het verleden desgewenst kan verifiëren

- Periode van uitvoering (start en opleverdatum)

- Inschrijfsom

- Uiteindelijke aanneemsom

- Korte karakteriserende beschrijving van het project en uw aandeel daarin (waarvoor was u verantwoordelijk)

- Korte beschrijving van projectorganisatie en samenwerkingsverbanden (denk aan onderaannemers)

\section{vraag 2 Project gerealiseerd binnen planning?}

$\mathrm{U}$ dient hier te vermelden op welke wijze u realisatie conform planning heeft gerealiseerd en op welke wijze u hierover de opdrachtgever heeft geïnformeerd. Tevens dient $\mathrm{u}$ hier aan te geven op welke wijze $\mathrm{u}$ dreigende overschrijdingen het hoofd heeft geboden. U kunt hierbij onder andere ingaan op:

- Gegevensverstrekking

- Knelpunten in de planning

- Benodigde installatietijd

vraag 3 Project gerealiseerd conform (kwaliteits)verwachtingen van de opdrachtgever?

$\mathrm{U}$ dient hier aan te geven in welke mate $\mathrm{u}$ aan de verwachtingen van uw opdrachtgever heeft kunnen voldoen. U kunt hierbij ingaan op zaken als:

- Het nakomen van afspraken

- Het tijdig informeren t.a.v. afwijkingen

- De door u ten toon gespreide flexibiliteit

- Het door u getoonde vakmanschap 
vraag 4 Complexe bouwopgave.

Was er bij dit project sprake van een complexe uitvoeringslogistiek t.a.v. tijdelijke voorzieningen in/door de "bouwput" voor goederenstromen,

bezoekersstromen, medewerkers en cliënten die ongehinderde doorgang moeten hebben? $U$ dient hier aan te geven wat uw ervaring in dit project is geweest met dit soort tijdelijke voorzieningen. Ook andere zaken t.a.v. uitvoerings- en bouwplaatslogistiek die voor dit project van UMC St Radboud interessant kunnen zijn, kunt u hier weergeven.

\section{vraag 5 Krappe bebouwde omgeving/continuïteit van bedrijfsvoering.}

Was er bij dit project sprake van een krappe bouwplaats waarbij tijdens de bouwactiviteiten de continuiteit van de bedrijfsvoering niet in het geding mocht zijn? (met toelichting). U kunt hier beschrijven op welke wijze $\mathrm{u}$ in dit project rekening hebt gehouden met het waarborgen van continuiteit van de bedrijfsvoering.

\section{vraag 6 Coördinatie en samenwerking (в).}

Was er bij dit project sprake van complexe installatietechnische aspecten die een prominente plaats (minstens $40 \%$ van de aanneemsom) hadden in dit project? $\mathrm{U}$ dient hier te beschrijven op welke wijze $\mathrm{u}$ de coördinatie en afstemming heeft geregeld met de installatietechnische aannemers en $\mathrm{u}$ zorg heeft gedragen voor een integraal aangestuurde en goed afgestemde bouwstroom. Wat bent $\mathrm{u}$ hierbij tegengekomen?

\section{vraag 7 Samenwerking/Belangenbehartiging ( $\mathbf{W} \& \mathbf{E})$.}

Was er bij dit project sprake van complexe installatietechnische aspecten die een prominente plaats (minstens $40 \%$ van de aanneemsom) hadden in dit project? $\mathrm{U}$ dient hier te beschrijven op welke wijze $\mathrm{u}$ uw belangen heeft gewaarborgd bij de coördinatie en afstemming tussen nevenaannemers en derden. Wat was uw rol bij deze samenwerking? $U$ dient tevens aan te geven hoe u zorg heeft gedragen voor goede kwaliteit van de werktekeningen.

vraag $\mathbf{8}$ Vastleggen specificaties.

Was er bij dit project sprake van een situatie waarin het gewenst was om pas op het spreekwoordelijke laatste moment bepaalde specificaties vast te leggen? (met toelichting). $\mathrm{U}$ dient hier te beschrijven op welke wijze u met deze tegenstrijdige belangen tussen opdrachtgever en opdrachtnemer bent omgegaan. Hoe heeft $u$ hierop in kunnen spelen? Welke communicatie en coördinatie heeft dit tot gevolg gehad? In welke mate heeft u bij dit project aan deze wens tegemoet kunnen komen? Hoe heeft $\mathrm{u}$ dat georganiseerd?

\section{vraag 9 Referentie.}

$\mathrm{U}$ dient aan te geven waarom $\mathrm{u}$ dit een geslaagd referentieproject vindt en wat uw toegevoegde waarde hierin was.

\section{vraag 10 Waardering.}

Denkt $\mathrm{u}$ dat uw voormalig opdrachtgever u voor een vergelijkbaar project graag weer aan het werk zou zien? Onderbouw uw antwoord. Welk rapportcijfer $(1-10)$ denkt $\mathrm{u}$ dat uw voormalig opdrachtgever $\mathrm{u}$ zal geven voor dit project?

Afbeelding 5.1; Illustratie van PPI Vragenlijst

Naast toepassing van het PPI element in de selectiefase is aan inschrijvers gevraagd een Plan van Aanpak op te stellen. Deze vraagstelling vertoont verwantschap met het RAP/RAVA zoals pips dat kent.

Het hanteren van PPI bij deze Europese Aanbesteding stuitte in de markt nogal op weerstand. Marktpartijen vroegen zich hardop af of "dit wel echt nodig was" en of "dit de kant is die de sector op zou moeten". Één partij heeft zich teruggetrokken vanwege de eis PPI in te leveren; net als bij de onderhoudsprojecten is hier dus ook sprake geweest van zelfselectie. Bij deze aanbesteding heeft PPI slechts in geringe mate onderscheidend vermogen opgeleverd (de scores lagen allen tussen 7,0 en 8,o). Dit beperkte onderscheidend vermogen is meest waarschijnlijk te verklaren vanuit het feit dat alleen de top van de markt zich gemeld heeft, en daarbinnen zijn de performance verschillen niet heel groot. Het aantal gegadigden was zo laag dat alle gegadigden die voldeden aan de uitsluitingsgronden en minimumvereisten uitgenodigd zijn tot het doen van een inschrijving. Voor geen enkel perceel waren er namelijk meer dan 8 gegadigden (dit heeft veel van doen met de markt- 
omstandigheden op het moment van deze aanbestedingsprocedure. Aannemers hadden een goed gevulde orderportefeuille). Van de drie bouwkundige aannemers die uitgenodigd werden, heeft één aannemer zich alsnog teruggetrokken. Het hanteren van een maximale inschrijfsom (ISmax) heeft ertoe geleid dat er maar weinig geldige inschrijvingen zijn die ook een PvA ingediend hebben: Voor alle drie de percelen bleef maar één geldige inschrijving over (deels veroorzaakt door het overschrijden van IS max, deels door andere factoren). Om toch zicht te krijgen op het onderscheidend vermogen van de gevraagde PvA's zijn de ingediende plannen voor de percelen $\mathrm{E}$ en $\mathrm{w}$ achteraf met elkaar vergeleken. De plannen zijn daartoe in geanonimiseerde vorm ter beschikking gesteld. Bij w scoorde het minst goede plan $55 \%$ (deze score wordt op index 100 gesteld) van het maximaal aantal te behalen punten en het beste plan $78 \%$ (deze index komt dan verhoudingsgewijs uit op 144). Bij E was dat 54 (index 10o) en $74 \%$ (index 137).

Het laten meewegen van de kwaliteit van plannen van aanpak levert dus in zekere mate onderscheidend vermogen op. Vooral als de projectdoelstellingen weerspiegeld worden in vooraf gedefinieerde criteria én daaraan gekoppelde wegingsfactoren, levert dit onderscheidend vermogen op, dat van nut kan zijn bij het gunnen aan de meest gerede partij.

In de tabel op de volgende pagina is te zien in welke mate de pips safeguards invloed hebben gehad op het reduceren van onzekerheid, het ontmoedigen van de neiging tot het vertonen van opportunistisch gedrag en het omgaan met begrensde rationaliteit van actoren. De weergaves zijn gebaseerd op de hiervoor weergegeven beschrijvingen van deze praktijkcase.

$\begin{array}{llll}\begin{array}{l}\text { Nieuwbouw } \\ \text { Fase III } \\ \text { UMC St Radboud }\end{array} & \begin{array}{l}\text { Bijdrage aan } \\ \text { reduceren } \\ \text { onzekerheid }\end{array} & \begin{array}{l}\text { Bijdrage aan het } \\ \text { ontmoedigen van } \\ \text { opportunistisch } \\ \text { gedrag }\end{array} & \begin{array}{l}\text { Bijdrage aan het om- } \\ \text { gaan met begrensde } \\ \text { rationaliteit }\end{array} \\ \text { Budgetinf } & \begin{array}{l}\text { Ondanks sellers } \\ \text { market dankzij dit } \\ \text { element toch geldige } \\ \text { inschrijvingen }\end{array} & \begin{array}{l}\text { Tijdens realisatie is } \\ \text { samenwerking } \\ \text { constructief ver- } \\ \text { lopen. Reële niveau } \\ \text { van ISmax heeft daar- } \\ \text { toe bijgedragen }\end{array} & \begin{array}{l}\text { Geen direct effect } \\ \text { op dit mechanisme }\end{array} \\ & \text { neutraal } & \\ \text { PPI } & \text { neutraal } & & \text { neutraal }\end{array}$

Tabel 5.5; Safeguards en hun effecten bij UMC St Radboud fase III

De mate waarin het theoretisch model actief was en dit leidde tot de verwachtte resultaten

Er heeft geen nadere selectie van gegadigden plaatsgevonden in verband met het geringe aantal gegadigden zoals hiervoor uiteengezet. PPI heeft dus ook geen invloed gehad op het verdere verloop van de aanbesteding. Voor de effecten van kwaliteitsverschillen in de PvA's geldt hetzelfde. Omdat per perceel maar één geldige inschrijving resteerde, heeft de kwaliteit van de ingediende PvA's ook geen stempel gedrukt op het verdere verloop van deze aanbesteding. Het verdere verloop van dit project is in de uitvoering dan ook niet intensief gevolgd in het kader van dit onderzoek.

\section{Leerpunten en deelconclusies}

Geschiktheid project

Dit project was minder geschikt omdat er een compleet uitgewerkt
** deze neutrale score is het gevolg van het feit dat PPI defacto geen invloed heeft gehad vanwege het feit dat er per preceel maar één geldige inschrijving was en er dus niets te selecteren viel. 
bestek op de markt werd gebracht. Dat beperkte de toepassingsmogelijkheden voor de pips safeguards, die daardoor ook maar in heel beperkte mate aan de orde waren zoals al eerder gememoreerd.

\section{Ontleren en omdenken}

pips heeft bij dit project slechts een bescheiden rol gespeeld. Met name vanwege de manier van specificeren, heeft het ontleren en omdenken een geringere rol gespeeld.

\section{Effectiviteit pips}

Doordat de pips safeguards geen feitelijke invloed hebben gehad (er heeft geen nadere selectie plaatsgevonden op basis van PPI omdat er maar één marktpartij overbleef), zijn er ook minder leerpunten en deelconclusies te trekken zoals bij eerdere praktijkcases weergegeven. In geval van een enigszins heterogeen samengestelde groep gegadigden waaruit geselecteerd kan worden, is de verwachting dat deze wijze van PPI verzamelen en beoordelen zal leiden tot bruikbare informatie die de voorspelbaarheid van aanbestedingen vergroot en opportunistisch gedrag ontmoedigt. Deze wijze van PPI verzamelen voldoet aan het proportionaliteitsbeginsel en aan de beginselen omtrent objectiviteit, transparantie en non discriminatie. Deze wijze van PPI verzamelen komt tegemoet aan de bezwaren zoals marktpartijen die ervaren en juristen die duiden bij de 'Kashiwagi methode'. De plannen van aanpak (RAP/RAVA plannen in PiPs termen) bieden onderscheidend vermogen dat inderdaad kan bijdragen tot het gunnen aan de meest geschikte partij.

\section{Coöperatief versus competitief}

Door het geringe aantal inschrijvers per perceel, is van competitie uiteindelijk weinig tot geen sprake geweest. pips heeft haar stempel dan ook niet kunnen drukken op deze aanbesteding; de mate van coöperatief gedrag is dan ook niet aan het toepassen van enkele pips safeguards toe te schrijven.

\section{Juridische rechtmatigheid}

Ook op dit gebied is de conclusie dat toepassing van pips elementen geen sturende invloed heeft gehad op deze aanbesteding. PPI formulie- ren en wijze van beoordelen voldoen aan objectiviteits vereisten. De wijze van PPI verzamelen en beoordelen zoals in het kader van deze aanbesteding ontwikkeld, komt tegemoet aan de bezwaren ten aanzien van subjectiviteit zoals die bij de 'Kashiwagi werkwijze' worden gezien. Beoordeling van RAP/RAVA's heeft enkel achteraf (off the record) plaatsgevonden; vanwege het ontbreken van meerdere marktpartijen, zou beoordeling van RAP/RAVA immers geen toegevoegde waarde hebben.

\section{Samenvattend:}

De belangrijkste uitkomst van deze aanbesteding wordt gevornd door de alternatieve werkwijze voor het verzamelen en beoordelen van PPI. Deze werkwijze komt beter tegemoet aan het

proportionaliteitsbeginsel, scoort beter ten aanzien van objectiviteit, reduceert transactiekosten en geeft meer informatie die relevant is voor het nu aan te besteden werk. Toepassing van PPI (en ook RAP/RAVA) heeft echter (vanwege het ontbreken van voldoende competitie) weinig impact gehad bij deze aanbesteding.

\subsection{Bergbezinkbassin gemeente's-Hertogenbosch}

\section{Aanleiding en wijze van dataverzameling}

Na een aantal aanbestedingen voor een private opdrachtgever te hebben begeleid, was de vraag vanuit de gemeente 's-Hertogenbosch welkom om samen met Breijn raadgevende ingenieurs de pips aanbesteding van de aanleg van een bergbezinkbassin te begeleiden. Daarnaast was het een pré dat dit een project betrof in de civieltechnische sector; de eerder uitgevoerde praktijkcases hadden allen betrekking op de utiliteitsbouw. Als derde positieve element geldt het feit dat een publieke opdrachtgever een uitgebreide juridische check wilde laten uitvoeren om te bezien of pips toepasbaar is tegen een aanvaardbaar claimrisico. Zoals hiervoor (hoofstuk vier) te lezen valt zijn aldus twee varianten voor toepassing van pips ontstaan die toepasbaar zijn onder het ARW 2005.

Scores zijn tot stand gekomen door de leden van een beoordelingscommissie individueel te laten beoordelen. Gerekend is met het rekenkundig gemiddelde van die individuele scores. Van alle scores en daarmee 
uitgevoerde berekeningen zijn Excel files (alsmede originele beoordelingsformulieren) beschikbaar

Door de projectorganisatie van de gemeente 's-Hertogenbosch is uitgebreid verslag gelegd van de verschillende meetings om de aanbesteding voor te bereiden. Van de interviews met de sleutelfunctionarissen zijn audiotapes beschikbaar. Van de evaluatie met de aannemer en de opdrachtgever zijn eveneens verslagen beschikbaar.

De methodologische kwetsbaarheid wordt gevormd door het feit dat, alhoewel de juridische check (onder verantwoordelijkheid van Corvers Legal Affairs) robuust is uitgevoerd, dit geen Europese aanbesteding betrof (omvang onder de drempelwaarde). Wanneer het wel een formele Europese procedure was geweest, zou het claimrisico wellicht anders ingeschat zijn. We hebben dus nu wel een indicatie dat de elementen bij een vergelijkbaar project toepasbaar zijn, maar echt bewijs daarvoor is pas beschikbaar wanneer jurisprudentie hieromtrent opgebouwd wordt. Net als bij Fase III van het UMC St Radboud is hier een uitgewerkt bestek in de markt gezet, waarbij aan gegadigden wel nadrukkelijk is gevraagd optimalisaties in te brengen en er ruimte was voor de engineering van de rotating equipment. De ambivalente signalen die daarvan uitgaan zijn tevens als methodologische kwetsbaarheid te zien.

\section{Korte project introductie}

PiPs toepassing bij BVP aanbesteding bergbezinkbassin gemeente 's-Hertogenbosch

De gemeente's-Hertogenbosch wilde een bergbezinkbassin aan laten leggen om daarmee bij hevige regenval hemelwater gecontroleerder te kunnen afvoeren met een lagere milieubelasting. Een dergelijk bassin vangt zo nodig water op om dit water pas na bezinking (in dit bassin/ buffer) te lozen op het oppervlakte water. De gemeente heeft daartoe een ontwerp en bestek laten maken door adviseurs die ze zelf heeft gecontracteerd. Dit project kent dientengevolge slechts een geringe mate van oplossingsvrijheid. Deze oplossingsvrijheid bestaat eruit dat marktpartijen is gevraagd optimalisaties aan te reiken ten opzichte van het uitgewerkte plan en de $\mathrm{E} \& \mathrm{~W}$ installatie zelf te concretiseren. Bij de aanleg van dit bergbezinkbassin is overlast voor omwonenden niet te voorkomen. Ook leven er bij omwonenden zorgen over verzakkingsgevaar omdat de grondwaterstand (tijdelijk) zal veranderen wannee er een bouwput wordt aangelegd waarin de 'betonnen bak' dient te worden gerealiseerd. De gemeente vindt het belangrijk dat het project tijdig, binnen budget en met zo min mogelijk hinder en negatieve consequenties voor omwonenden wordt opgeleverd. Marktpartijen zullen verantwoordelijk zijn voor al deze aspecten. De gemeente heeft er dan ook voor gekozen de communicatie met omwonenden deel uit te laten maken van deze verantwoordelijkheden.

De gemeente heeft een selectieleidraad samengesteld die op 29 april 2009 is gepubliceerd op www.aanbestedingskalender.nl bij de formele aankondiging van de opdracht. Deze selectieleidraad vermeldt tevens wat het maximaal beschikbare budget is dat aangewend zal worden

(830.0oo euro excl. BTw). De gevraagde werkzaamheden bestaan uit:

- Het leveren, aanleggen en gebruiksgereed opleveren van het bergbezinkbassin

- Het ontwerpen, leveren en aanbrengen van de werktuigbouwkundige installatie

- Het ontwerpen, leveren en aanbrengen van de elektrotechnische installatie

- Het verzorgen van de gehele communicatie rond dit project

- Het coördineren en begeleiden van de nutsvoorzieningen voor de werkende installatie

- Het verzorgen van revisiegegevens en -tekeningen

- Het verzorgen van de administratie

- Het beheren en onderhouden van een werkend bergbezinkbassin voor een periode van zes maanden

- Het compleet opleveren van de installatie, het werk en bij overdracht behorende documenten aan het einde van de periode van zes maanden aan de gemeente's-Hertogenbosch

Omdat de gemeente deze aanbesteding als pilot ziet, is bij de inrichting van de (niet openbare) procedure gehandeld alsof aan alle formele verplichtingen boven de drempelbedragen voldaan moet worden. Naast de schriftelijke uitleg over BVP die deel uitmaakt van de selectieleidraad is voorzien in een informatiebijeenkomst op 13 mei 2009 waarin de 
BVP methode verder is toegelicht en waarbij vragen gesteld konden worden door geïnteresseerde marktpartijen. De inrichting van de hierbij gevolgde procedure is conform de in het vorige hoofdstuk geschetste procedure waarbij het belang van proceskwaliteit en de daarvoor benodigde competenties een dominante rol vervullen (variant I zoals beschreven in hoofdstuk vier wordt dus toegepast).

Bij dit project toegepaste safeguards:

Funcspec De projecten zijn aanbesteed op basis van bestek met de nadrukkelijke uitnodiging optimalisaties in te brengen. Ook was er ruimte voor het invullen van de E\&W installaties. Enkele marktpartijen hebben de geboden ruimte benut, anderen hebben daarvan afgezien. De winnende partij heeft er voor gekozen het voorliggende ontwerp aan te passen om te komen tot een effectievere bezinking die tevens lagere exploitatiekosten kent.

Budgetinf Het maximaal te besteden budget is vooraf aan marktpartijen bekend gemaakt. De 830.00o,- is door alle partijen gerespecteerd (hoogste inschrijving 829.000,en de laagste $780.000,-)$

PPI

Marktpartijen hebben informatie ingeleverd over eerder gerealiseerde projecten. Dit heeft geleid tot een ranking waarbij de vijf hoogste PPI scores is gevraagd een aanbieding te maken.

RAVA Marktpartijen is gevraagd naar risico's en bijbehorende remedies. Ook hebben marktpartijen de ruimte gehad optimalisatievoorstellen in te brengen. Hiervan is wisselend gebruik gemaakt. De meeste aanbieders kozen voor prefab elementen in plaats van de in het bestek uitgewerkte, in het werk te storten, oplossing. Dit leidde tot kortere bouwtijd, minder overlast en gladdere oppervlaktes.
Qsleutelf De sleutelfunctionarissen zijn geinterviewd; interview resultaten hebben meegewogen bij deze aanbestedingen. Deze safeguard maakte veel onderscheidend vermogen zichtbaar. Stellen we de hoogste score op 100\%, dan bedraagt de laagste score slechts $58 \%$.

Pr/kwal Kwaliteit heeft voor 70\% meegewogen; prijs voor $30 \%$. In dit geval had de inschrijver met de hoogste kwaliteitsscore ook de laagste prijs (hij was in staat met inzet van de minste middelen de meeste waarde te creëren).

Tabel 5.6; Safeguards en hun effecten bij bergbezinkbassin 's-Hertogenbosch

In de tabel op de volgende pagina is te zien in welke mate de pips safeguards invloed hebben gehad op het reduceren van onzekerheid, het ontmoedigen van de neiging tot het vertonen van opportunistisch gedrag en het omgaan met begrensde rationaliteit van actoren. De weergaves zijn gebaseerd op de hiervoor weergegeven beschrijvingen van deze praktijkcase. 


\begin{tabular}{|c|c|c|c|}
\hline $\begin{array}{l}\text { Aanleg Berg- } \\
\text { bezinkbassin } \\
\text { 's-Hertogen- } \\
\text { bosch }\end{array}$ & $\begin{array}{l}\text { Bijdrage aan } \\
\text { reduceren } \\
\text { onzekerheid }\end{array}$ & $\begin{array}{l}\text { Bijdrage aan het } \\
\text { ontmoedigen van } \\
\text { opportunistisch } \\
\text { gedrag }\end{array}$ & $\begin{array}{l}\text { Bijdrage aan het om- } \\
\text { gaan met begrensde } \\
\text { rationaliteit }\end{array}$ \\
\hline Funcspec & $\begin{array}{l}\text { Er is aanbesteed op } \\
\text { basis van uitgewerkt } \\
\text { bestek. Winnende } \\
\text { partij heeft geboden } \\
\text { ruimte voor optima- } \\
\text { lisaties wel goed } \\
\text { benut }\end{array}$ & $\begin{array}{l}\text { Winnende partij } \\
\text { stond achter zijn } \\
\text { oplossing en wilde } \\
\text { die tot een succes } \\
\text { maken }\end{array}$ & $\begin{array}{l}\text { Geen direct effect } \\
\text { op dit mechanisme; } \\
\text { er is aanbesteed op } \\
\text { basis van een uitge- } \\
\text { werkt bestek }\end{array}$ \\
\hline Budgetinf & $\begin{array}{l}\text { Enkel geldige } \\
\text { inschrijvingen } \\
\text { ontvangen }\end{array}$ & $\begin{array}{l}\text { Hoogte van ISmax is } \\
\text { reëel gebleken. Er zijn } \\
\text { geen 'vervelende' } \\
\text { meerwerkdiscussies } \\
\text { geweest }\end{array}$ & $\begin{array}{l}\text { Het financiële kader } \\
\text { waarbinnen dit } \\
\text { project gerealiseerd } \\
\text { diende te worden was } \\
\text { voor alle betrokkenen } \\
\text { helder }\end{array}$ \\
\hline PPI & $\begin{array}{l}\text { Hanteren van PPI } \\
\text { maakte dat } 5 \text { partijen } \\
\text { een aanbieding } \\
\text { hebben gemaakt die } \\
\text { allen op basis van } \\
\text { hun ervaring dit werk } \\
\text { tot een goed einde } \\
\text { konden brengen }\end{array}$ & $\begin{array}{l}\text { De reputatie op } \\
\text { basis waarvan } \\
\text { inschrijvers zijn } \\
\text { geselecteerd is } \\
\text { tijdens de bouw } \\
\text { waar gemaakt }\end{array}$ & $\begin{array}{l}\text { Het hanteren en } \\
\text { beoordelen van PPI } \\
\text { bleek efficiënt moge- } \\
\text { lijk te zijn }\end{array}$ \\
\hline RAVA & $\begin{array}{l}\text { De winnende partij } \\
\text { diende een overtui- } \\
\text { gend plan in en bood } \\
\text { veel meerwaarde t.o.v. } \\
\text { het oorspronkelijke } \\
\text { ontwerp }\end{array}$ & $\begin{array}{l}\text { Commitment met } \\
\text { de eigen oplossing } \\
\text { resulteerde in } \\
\text { eagerness dit project } \\
\text { naar tevredenheid op } \\
\text { te leveren }\end{array}$ & $\begin{array}{l}\text { De belangrijkste } \\
\text { risico's en bijbeho- } \\
\text { rende remedies } \\
\text { waren overzichtelijk } \\
\text { in beeld. De aan- } \\
\text { nemer bleek tijdens } \\
\text { de uitvoering goed in } \\
\text { control te zijn }\end{array}$ \\
\hline
\end{tabular}

Qsleutelf

Grote verschillen; winnende partij zette sterk team in waarin veel vertrouwen bestond

$\begin{array}{ll}\mathrm{Pr} / \mathrm{kwal} & \text { Aandacht voor } \mathrm{Pr} / \\ & \text { kwal heeft bijgedra- } \\ & \text { gen aan projectsucces } \\ & \text { (zie ook hierboven) }\end{array}$

Dit vertrouwen is

Geen direct effect tijdens de uitvoering op dit mechanisme waargemaakt. Zowel v.w.b. omgevingsmanagement, bouwtechniek, projectmanagement en communicatie met opdrachtgever

Onderscheidend vermogen op

Geen direct effect geloond: kundige aannemer, voegde waarde toe, en maakte waar wat hij beloofde

Tabel 5.7; invloed safeguards op NIE mechanismen bij bergbezinkbassin's-Hertogenbosch

De mate waarin het theoretisch model actief was en dit leidde tot de verwachtte resultaten.

Mechanisme $\mathbf{1}$

TOEPASSING VAN PIPS ELEMENTEN REDUCEERT ONZEKERHEID. De verzamelde informatie over prestaties uit het verleden, over hoe partijen tegen risico's aankijken en aangeven ermee om te gaan, over de wijze waarop sleutelfunctionarissen denken het project aan te pakken en te managen, heeft de marktonzekerheid (selecteer ik wel de juiste partij) en de behoefteonzekerheid (zie hoofdstuk 3) aanzienlijk gereduceerd. Ook de transactieonzekerheid is gereduceerd; het werk is 
inmiddels binnen planning en budget naar tevredenheid uitgevoerd.

Mechanisme 2

TOEPASSING VAN PIPS ELEMENTEN REDUCEERT RUIMTE VOOR EN NEIGING TOT OPPORTUNISME.

De gecontracteerde partij heeft de bestekoplossing omgewerkt naar een eigen oplossing. Hij heeft in de praktijk ook commitment getoond ten opzichte van zijn eigen oplossing en zonder 'gedoe' invulling gegeven aan de gecontracteerde opdracht. Ook heeft prijs maar voor $30 \%$ meegewogen waardoor de nadelen van de 'laagste-prijs-klem' niet gevoeld werden. Tijdens de bouw is zowel bouwtechnisch als qua procesmanagement sprake geweest van high performance en de belangen van de opdrachtgever zijn goed gediend.

Mechanisme 3

TOEPASSING VAN PIPS ELEMENTEN DRAAGT BIJ AAN HET OMGAAN MET BEGRENSDE RATIONALITEIT.

Doordat de hoeveelheid te beoordelen informatie beperkt was en aangeleverd was in heldere formats en van meet af aan duidelijkheid bestond over beoordelingscriteria en wegingsfactoren, is efficiënte en in redelijke mate geobjectiveerde beoordeling mogelijk gebleken. Ook bij de in beginsel subjectieve interviews is veel aandacht besteed aan het objectiveren, waardoor alle marktpartijen aan een zelfde mate van subjectiviteit hebben bloot gestaan, hetgeen ook een zekere mate van objectiviteit impliceert.

\section{Leerpunten en deelconclusies}

\section{Geschiktheid project}

Dit project bleek geschikt; qua omvang en qua mate van distantie; het bleek goed mogelijk de verantwoordelijkheden van dit project te

beschrijven en over te dragen aan de winnende marktpartij. Enerzijds een bestek bijvoegen en anderzijds vragen naar optimalisaties heeft echter iets tweeslachtigs. Een oplossingsvrije vraagformulering heef de voorkeur omdat dit leidt tot groter onderscheidend vermogen.

\section{Ontleren en omdenken}

Afgerond bestek is op de markt gezet. Ontleren en omdenken heeft dientengevolge geen rol van betekenis gespeeld. Wel was het voor beoordelaars niet altijd even eenvoudig vooral te focussen op kwaliteitsverschillen en die verschillen in hun scores tot uiting te brengen.

\section{Effectiviteit Pips}

pips heeft geleid tot gunning aan een bewezen competente aanbieder die op een goede wijze gebruik heeft gemaakt van de geboden (optimalisatie)ruimte. Deze aanbieder heeft het project naar tevredenheid binnen planning en budget opgeleverd. Na selectie en gunning op 'BVP wijze' zou er een contract moeten komen dat voortborduurt op de prikkels en risicoverdeling zoals die tijdens de aanbesteding zijn opgetreden c.q. gecreëerd.

\section{Coöperatief versus competitief}

De samenwerking is gedurende de uitvoeringsfase coöperatief verlopen. Zowel naar de opdrachtgever als naar de omgeving. Het feit dat kwaliteit dominant zwaarder heeft meegewogen dan prijs, alsmede de ruimte voor optimalisaties (het project naar de eigen hand zetten) heeft daaraan bijgedragen.

\section{Objectiviteit en transparantie}

Beoordelaars hebben nog wat meer houvast (protocol) nodig. Dit om te voorkomen dat de ene beoordelaar zich bijvoorbeeld laat leiden door de verschillen tussen de aanbiedingen, terwijl een andere beoordelaar meer in absolute zin beoordeelt. Ook het toekennen van scores van ingediende PPI projecten die op het eerste gezicht minder relevant lijken, is door beoordelaars verschillend opgepakt.

\section{Juridische rechtmatigheid}

Er zijn geen claims ingediend. Het interviewen van de sleutelfunctionarissen was op dit gebied het meest risicovolle onderdeel. De uitgebreide 
juridische checks in combinatie met de nodige maatregelen met betrekking tot objectiveren hebben bijgedragen aan het uitblijven van claims.

\section{Overige leerpunten}

Het aantal gegadigden was beperkt. Er zijn marktpartijen die wel de selectieleidraad hebben gedownload, maar niet als gegadigde hebben meegedaan. Achterliggende oorzaken zijn niet bekend. In het vervolg is het de moeite waard dit na te gaan.

Partijen gaven aan dat ze het betreurden dat er geen ruimte werd gegeven voor het toevoegen van een tekening die hun oplossing verduidelijkt. Dit punt zal de gemeente 's-Hertogenbosch meenemen bij een volgend traject.

Nogmaals kritisch kijken naar welke documenten je op welke momenten verlangt. Kun je bijvoorbeeld volstaan met een eigen verklaring en bij gunning van alleen de partij aan wie je gunt de onderliggende documenten opvragen?

Het aantal interviewvragen kan vanwege een stuk overlap zoals dat is gebleken, worden gereduceerd.

Het voorschrijven van een format voor het RAva blijkt achteraf niet effectief. Kan beperkt worden tot de simpele vraag: "indiceer en

prioriteer de risico's zoals jij dat ziet en beschrijf hoe je met die risico's om zult gaan".

\section{Samenvattend:}

De aanbesteding van het bergbezinkbassin is effectief en efficiënt verlopen. Het werk is tijdig, binnen budget en naar tevredenheid opgeleverd. Er is veel aandacht besteed aan de juridische risico's die verbonden zijn aan het interviewen van sleutelfunctionarissen. De bij dit project toegepaste BVP aanbestedingsvorm bleek mogelijk tegen een aanvaardbaar claimrisico.

\subsection{Cross Case Analyse}

In deze paragraaf worden de verschillende praktijkcases in één overzicht samengebracht waarbij verduidelijkt wordt welke pips elementen een rol gespeeld hebben, tot welke effecten dat heeft geleid en in hoeverre de NIE mechanismen hebben gefunctioneerd. Dit overzicht legt de basis om tot conlusies te komen die de individuele praktijkcases overstijgen.

\begin{tabular}{|c|c|c|c|c|c|c|c|c|}
\hline \multirow[b]{2}{*}{ Funcspec } & \multicolumn{2}{|c|}{$\begin{array}{l}\text { Onderhouds } \\
\text { Projecten } \\
\text { UMC St } \\
\text { Radboud } \\
\text { Toegep? }\end{array}$} & \multicolumn{2}{|c|}{$\begin{array}{l}\text { Parkeer } \\
\text { Garage } \\
\text { UMC St } \\
\text { Radboud } \\
\quad \text { Toegep? }\end{array}$} & \multicolumn{2}{|c|}{$\begin{array}{l}\text { Nieuwbouw } \\
\text { Fase III } \\
\text { UMC St } \\
\text { Radboud } \\
\text { Toegep? }\end{array}$} & \multicolumn{2}{|c|}{$\begin{array}{l}\text { Berg } \\
\text { Bezink } \\
\text { Bassin } \\
\text { 's-Hertogenbosch } \\
\text { Toegep? }\end{array}$} \\
\hline & ja & + & ja & + & nee & & ja & + \\
\hline Budginf & ja & + & ja & + & ja & + & ja & + \\
\hline PPI & ja & + & deels & + & $\mathrm{ja}^{*}$ & & ja & + \\
\hline RAVA & ja & + & deels & + & deels ${ }^{\star}$ & - & ja & + \\
\hline Qsleutelf & ja & + & deels & + & nee & & ja & + \\
\hline $\operatorname{Pr} / \mathrm{kwal}$ & $\mathrm{ja}$ & + & ja & + & nee & & ja & + \\
\hline Risktrans & nee & & $\mathrm{ja}$ & + & nee & & ja & + \\
\hline Harddat & nee & & ja & + & nee & & ja & + \\
\hline PCR & nee & & nee & & nee & & nee & \\
\hline
\end{tabular}




\begin{tabular}{|c|c|c|c|c|}
\hline $\begin{array}{l}\text { Reductie } \\
\text { Onzekerh. }\end{array}$ & $\begin{array}{l}\text { Ja; ondanks } 1^{\mathrm{e}} \\
\text { toepassing } \\
\text { leidde pips tot } \\
\text { minder } \\
\text { onzekerheid. }\end{array}$ & $\begin{array}{l}\text { Ja; Zeer ervaren } \\
\text { partij gecon- } \\
\text { tracteerd, } \\
\text { overdracht van } \\
\text { uitvoerings- } \\
\text { risico's. }\end{array}$ & $\begin{array}{l}\text { Ja; invloed pips } \\
\text { is echter gering, } \\
\text { werkzame ele- } \\
\text { menten hebben } \\
\text { niet tot nadere } \\
\text { selectie geleid. }\end{array}$ & $\begin{array}{l}\text { Ja; dankzij info } \\
\text { waarover } \\
\text { opdrachtgever } \\
\text { dankzij pips } \\
\text { beschikte was } \\
\text { er weinig onze- } \\
\text { kerheid over. }\end{array}$ \\
\hline $\begin{array}{l}\text { Ontmoed. } \\
\text { Opport. }\end{array}$ & $\begin{array}{l}\text { Ja; gunnen op } \\
\text { waarde en } \\
\text { eigen oplossing } \\
\text { laten realiseren } \\
\text { heeft tot } \\
\text { constructieve } \\
\text { samenwerking } \\
\text { geleid }\end{array}$ & $\begin{array}{l}\text { Ja; verantwoor- } \\
\text { delijkheden zijn } \\
\text { goed 'gepakt' } \\
\text { en zonder } \\
\text { 'gedoe' waar- } \\
\text { gemaakt }\end{array}$ & $\begin{array}{l}\text { Ja; invloed pips } \\
\text { is echter gering, } \\
\text { werkzame } \\
\text { elementen } \\
\text { hebben niet tot } \\
\text { nadere selectie } \\
\text { geleid }\end{array}$ & $\begin{array}{l}\text { Ja; Er is geen } \\
\text { gedrag ver- } \\
\text { toond dat de } \\
\text { belangen van } \\
\text { de opdrachtge- } \\
\text { ver schaadde }\end{array}$ \\
\hline $\begin{array}{l}\text { Inspelen } \\
\text { op beg. } \\
\text { Ration. }\end{array}$ & $\begin{array}{l}\text { Ja; beknopte } \\
\text { documenten } \\
\text { en alles } \\
\text { countable } \\
\text { maken heeft } \\
\text { bijgedragen } \\
\text { aan hanteer- } \\
\text { baarheid }\end{array}$ & $\begin{array}{l}\mathrm{Ja} \text {; functionele } \\
\text { spec was } \\
\text { achteraf bezien } \\
\text { te beknopt, } \\
\text { maar dankzij } \\
\text { coöperatieve } \\
\text { mindset heeft } \\
\text { dit niet tot } \\
\text { problemen } \\
\text { geleid }\end{array}$ & $\begin{array}{l}\text { Ja; invloed pips } \\
\text { is echter gering, } \\
\text { werkzame } \\
\text { elementen } \\
\text { hebben niet tot } \\
\text { nadere selectie } \\
\text { geleid }\end{array}$ & $\begin{array}{l}\text { Ja; aanbeste- } \\
\text { ding verliep } \\
\text { efficiënt, ook } \\
\text { tijdens de } \\
\text { uitvoering was } \\
\text { relatief weinig } \\
\text { management- } \\
\text { capaciteit van } \\
\text { opdrachtgever } \\
\text { nodig }\end{array}$ \\
\hline
\end{tabular}

* Per perceel slechts één gegadigde; vandaar dat toepassing van deze elementen niet tot verdere selectie heeft geleid
Uit bovenstaande tabel blijkt dat in die gevallen waarin bij de praktijkcases pips elementen zijn toegepast, dit heeft geleid tot positieve effecten (in de tabel weergegeven als ' + '). Uitzondering is PPI en RAVA bij de nieuwbouw van fase III ten behoeve van het UMC St Radboud. Verklaring daarvoor is gelegen in het feit dat het aantal gegadigden (uiteindelijk één per perceel) zo gering was dat er geen verdere selecterende werking van deze elementen uit kon gaan. Daarnaast toont de tabel aan (onderbouwing van de ' + ' scores is te vinden in de uitgebreidere beschrijvingen bij de individuele cases) dat in alle gevallen waarin de realisatie van het aanbestede werk heeft plaatsgevonden de NIE mechanismen opgetreden zijn zoals vanuit het theoretische model verondersteld.

Behalve bovenstaande analyse aan de hand van de safeguards, wordt deze cross case analyse ook uitgevoerd voor wat betreft de leerpunten en conclusies. Zie daartoe onderstaande tabel.

\begin{tabular}{|c|c|c|c|c|}
\hline $\begin{array}{l}\text { Leerpunten \& } \\
\text { conclusie }\end{array}$ & $\begin{array}{l}\text { OH proj. UMC St } \\
\text { Radboud }\end{array}$ & $\begin{array}{l}\text { Parkeer } \\
\text { Garage } \\
\text { UMC St } \\
\text { Radboud }\end{array}$ & $\begin{array}{l}\text { Nieuwbouw } \\
\text { Fase III } \\
\text { UMC St } \\
\text { Radboud }\end{array}$ & $\begin{array}{l}\text { Bergbezink- } \\
\text { bassin }\end{array}$ \\
\hline $\begin{array}{l}\text { Geschiktheid } \\
\text { project }\end{array}$ & $\begin{array}{l}\text { Eigenlijk te klein; } \\
\text { als eerste } \\
\text { proeftuin echter } \\
\text { welkom }\end{array}$ & $\begin{array}{l}\text { Project bij } \\
\text { uitstek geschikt } \\
\text { qua omvang, } \\
\text { uitdagingen en } \\
\text { qua 'karakter' }\end{array}$ & $\begin{array}{l}\text { Minder geschikt; } \\
\text { er werd een } \\
\text { traditioneel } \\
\text { bestek op de } \\
\text { markt gezet }\end{array}$ & $\begin{array}{l}\text { Project in } \\
\text { beginsel } \\
\text { geschikt. } \\
\text { Traditioneel } \\
\text { bestek als basis } \\
\text { in combinatie } \\
\text { met pips minder } \\
\text { geschikt }\end{array}$ \\
\hline $\begin{array}{l}\text { Ontleren \& } \\
\text { omdenken }\end{array}$ & $\begin{array}{l}\text { Heeft duidelijk } \\
\text { stempel gedrukt } \\
\text { op het proces }\end{array}$ & $\begin{array}{l}\text { Projectteam } \\
\text { wilde van meet } \\
\text { af aan oplossin- } \\
\text { gen vanuit de }\end{array}$ & $\begin{array}{l}\text { Er is technisch } \\
\text { gespecificeerd; } \\
\text { geen issue } \\
\text { geweest }\end{array}$ & $\begin{array}{l}\text { Er is technisch } \\
\text { gespecificeerd; } \\
\text { geen issue } \\
\text { geweest }\end{array}$ \\
\hline
\end{tabular}


Effectiviteit

pips

Alle drie de projecten binnen planning en

budget en naar tevredenheid

opgeleverd

Coöperatief Geen conflictvs competitief cultuur; goede samenwerking

$\begin{array}{lll}\text { Coöperatieve } & \text { Coöperatieve } & \text { Coöperatieve } \\ \text { samenwerking. } & \text { samenwerking. } & \text { samenwerking. } \\ \text { Gemaakte } & \text { Is echter niet } & \text { Gemakkte af- } \\ \text { afspraken zijn } & \text { aantoonbaar } & \text { spraken zijn } \\ \text { zonder mitsen } & \text { aan pips toe te } & \text { zonder mitsen } \\ \text { en maren waar- } & \text { schrijven van- } & \text { en maren waar- } \\ \text { gemaakt en } & \text { wege ontbreken } & \text { gemaakt en na- } \\ \text { nagekomen } & \text { competitie } & \text { gekomen }\end{array}$

Objectiviteit \& Kanttekeningen Geen opmertransparantie bij PPI werkwijze. kingen of

Idem v.w.b.

protesten

relatieve scores geweest

\section{Juridische Niet echt een Niet echt een rechtmatig- issue geweest issue geweest}

eerdere bezwa- geweest.

\section{Nieuw ont- Geen opmer-}

wikkelde PPI kingen of

werkwijze heeft protesten

ren ondervangen Beoordelingsin-

structie verder

aanscherpen

Geen bezwaren Uitgebreid of protesten. getoetst. Alle Wellicht dankzij pips safeguards nieuwe PPI werk- (behalve PCR) wijze een aanvaardbaar claimrisico worden toegepast

Overige

leerpunten

Selectieleidraad moet nog eenduidiger

Outputsprecifi- Terughouden catie was achter- zijn met BVP af bezien toch te wanneer beknopt

traditioneel bestek wordt gehanteerd

Overall beeld Waardevolle Al veel meer Vanwege ont- Ondanks tradieerste leererva- BVP project dan breken compe- tioneel bestek als ringen voor onderhouds- titie beperkte basis heeft volgende projecten. aan pips toe te winnende partij

projecten Schoolvoorbeeld schrijven effec- optimaal gebruik van 'ruimte ten. Meerwaarde gemaakt van geven aan de zit in nieuwe optimalisatie markt' PPI werkwijze mogelijkheden en is BVP signatuur goed uit de verf gekomen

Tabel 5.9; cross case analyse leerpunten en conclusies

Tabel 5.9 laat zien dat de praktijkcases inzicht hebben verschaft omtrent de geschiktheid (voor toepassing van BVP) van projecten, het ontleren, ruimte geven aan marktpartijen (door het stellen van vragen met oplossingsruimte), de werking van pips en de effecten die bij toepassing van de safeguards optreden. Daarnaast hebben in de praktijk cases waardevolle aanpassingen aan de PiPS methodiek plaats gevonden. Bij de vier beschreven praktijkcases bleek de samenwerking coöperatief en werd binnen planning en budget naar tevredenheid opgeleverd: De NIE mechanismen zijn actief. Het uitvoeren van de praktijkcases heeft voor dit onderzoek grote betekenis: verbeterde PPI werkwijze, ontdekken welke projecten meer/minder geschikt zijn, procesontwerp voor niet openbare procedure. Al deze zaken hangen samen met casu quo zijn ontwikkeld in het kader van de praktijkcases. 
De belangrijkste bevindingen ten aanzien van het toepassen van pirs elementen bij praktijkcases worden onderstaand weergegeven.

\section{Concluderend:}

Toepassing van PiPs elementen bij praktijkcases heeft de theoretische vooronderstellingen (draagt bij aan het reduceren van de ruimte voor en de neiging tot opportunistisch gedrag, het reduceren van onzekerheid en speelt in op bounded rationality) voor een belangrijk deel bevestigd. Waar deze mechanismen niet uit de verf kwamen, kan dit aan de hand van situationele omstandigheden worden beredeneerd en verklaard.

Bovenstaande conclusies kunnen ook verbonden worden aan aanbestedingen die de auteur van dit proefschrift heeft mogen begeleiden nadat de fase van datacollectie van dit onderzoek was afgerond. In Bijlage $\mathrm{X}$ is een tabel opgenomen die een overzicht geeft van 15 uitgevoerde BVP aanbestedingen die allen binnen planning en budget en naa tevredenheid van de opdrachtgever en opdrachtnemer zijn uitgevoerd.

\subsection{Deelconclusies praktijkcases}

De toepassingen in de verschillende praktijkcases leiden tot de volgende deelconclusies.

\section{Deelconclusie $\mathbf{5 . 1}$}

PIPS SAFEGUARDS BLIJKEN BIJ DE PRAKTIJKCASES ONZEKERHEID TE REDUCEREN EN DAARMEE BIJ TE DRAGEN AAN

PROJECTSUCCES.

Er is meer informatie voorhanden (PPI, RAVA en kwalitet sleutelfunctionarissen); dat reduceert voor opdrachtgevers behoefteonzekerheid, transactieonzekerheid en contractuele onzekerheid. Opdrachtnemers zijn minder onzeker over het te realiseren financieel resultaat en minder onzeker omdat ze hun stempel op het project hebben kunnen drukken.
Deelconclusie $\mathbf{5 . 2}$

PIPS SAFEGUARDS BLIJKEN BIJ DE PRAKTIJKCASES DE NEIGING TOT HET VERONEN VAN OPPORTUNISTISCH GEDRAG NA

GUNNING TE ONTMOEDIGEN EN DAARMEE BIJ TE DRAGEN AAN PROJECTSUCCES.

Gunnen op waarde, meer ruimte voor inbreng door de aannemer, mee (verhoogde mate van) commitment met de te realiseren oplossing, dragen daaraan bij.

\section{Deelconclusie $\mathbf{5 \cdot 3}$}

PIPS SAFEGUARDS HOUDEN BIJ DE PRAKTIJKCASES REKENING MET BEGRENSDE RATIONALITEIT EN DRAGEN DAARDOOR BIJ AAN PROJECTSUCCES.

Focus op compacte informatie die onderscheidend vermogen bevat en het countable maken van de kwaliteit van de in het kader van de safeguards ingebrachte informatie dragen daaraan bij. 


\section{validatie van theoretische}

bevindingen door kwantitatief onderzoek

6.1 Waarom kwantitatief onderzoek?

Uit het verkennend onderzoek (van Bentum, 2005) blijkt dat PiPs wise aanbestede projecten tot goede resultaten leiden. De NIE inzichten zoals in hoofdstuk drie besproken, vormen een bruikbaar theoretisch kader. Hoofdstuk vijf laat zien dat de resultaten van de praktijkcases ook in de richting van de vooronderstelde effecten wijzen. Naast de in de Verenigde Staten opgedane ervaringen, het verklarende theoretische model en de indicaties die de praktijkcases inbrengen, is er de behoefte 
${ }^{82}$ Hier wordt bewust over 'verwacht' gesproken omdat er ten tijde van dit kwantitatief onderzoek (2009) nog maar weinig ervaring is met het toepassen van deze innovatieve elementen. om door middel van kwantitatief onderzoek nadere externe validatie te verkrijgen. Hierin ligt de oorsprong van dit hoofdstuk.

Het theorievormend deel van dit onderzoek (hoofdstukken twee $\mathrm{t} / \mathrm{m}$ vier) heeft betrekking op de werking en de verklaring van het succes van pips. Daartoe is, door middel van theoretische redeneringen een relatie gelegd tussen de pips elementen, de NIE safeguards en vooronderstelde effecten met betrekking tot het reduceren van onzekerheid en het ontmoedigen van de neiging tot opportunistisch gedrag (zie hoofdstuk drie).

Zoals in hoofdstuk drie geconstateerd, is de verklaring die Kashiwagi inbrengt (Імт еn кSM) hoofdzakelijk gericht op 'inspelen op begrensde rationaliteit' en gaat hij minder in op de NIE mechanismen 'reduceren van onzekerheid' en 'ontmoedigen van de neiging tot opportunistisch gedrag'. Daarnaast is, zoals al in hoofdstuk drie uiteengezet, begrensde rationaliteit van actoren als een gegeven te beschouwen. De mate van begrensde rationaliteit is niet door pips te beïnvloeden, wel is inzichtelijk gemaakt dat pips de ongewenste consequenties van begrensde rationaliteit reduceert. Begrensde rationaliteit manifesteert zich in het niet optimaal benutten van informatie waardoor er door actoren beslissingen genomen worden in plaats van dat de beschikbare informatie wordt verwerkt, geïnterpreteerd en benut. Zo beschouwd zijn de consequenties van begrensde rationaliteit te zien als een vorm van onzekerheid. De invloeden die pips elementen hebben op de consequenties van begrensde rationaliteit worden in dit kwantitatieve onderzoek dan ook geschaard onder 'het beperken van onzekerheid'.

Dit kwantitatieve onderzoek heeft tot doel de theoretische redeneringen met betrekking tot de NIE mechanismen a.) ontmoedigen van de neiging tot opportunistisch gedrag en b.) reduceren van onzekerheid, te toetsen aan praktijkinzichten aan opdrachtgevers- en opdrachtnemerszijde. Met andere woorden: dit kwantitatieve onderzoek moet antwoord geven op de vraag in welke mate 'de praktijk' verwacht ${ }^{82}$ dat de toepassing van pips elementen zal leiden tot de effecten die we vanuit het theore-

tisch model verwachten. Daarom zijn de vragen in dit onderzoek ook toegespitst op stellingen die geconstrueerd zijn rond een if/than statement. Voorbeeld: "Als opdrachtgevers naast prijs ook kwaliteit meewegen, dan...". Het doel is immers te onderzoeken in welke mate praktijkinzichten deze theoretische redeneringen onderschrijven. Daarom is ervoor gekozen respondenten scores te laten toekennen die een maat vormen voor de relatie tussen een pips element en een verwacht effect; de zogenoemde gepercipieerde relatie. Er wordt dus expliciet gevraagd naar de relatie tussen twee variabelen. Veel kwantitatieve onderzoeken hanteren een ander model; er wordt gevraagd naar de waardering van twee (of meer) losse variabelen en vervolgens wordt met behulp van statistische bewerkingen ingezoomd op de relaties/samenhangen tussen deze variabelen en wordt gezocht naar factoren die deze relaties/ samenhangen kunnen verklaren. Bij dit type onderzoek ligt een zwaarder accent op de zogenoemde onderzoekende statistiek. Bij het in dit proefschrift gehanteerde model ligt het accent meer op de beschrij vende statistiek die ingaat op de vraag in welke mate respondenten verwachte effecten onderschrijven, en is de onderzoekende statistiek minder prominent aanwezig.

\subsection{Opbouw en verantwoording}

De met dit kwantitatief onderzoek te toetsen theoretische redenering komt neer op het volgende. De pips elementen functioneren als safeguards (zie NIE theorie in hoofdstuk drie). Toepassing van deze safeguards reduceert onzekerheid, verkleint de ruimte voor en de neiging tot het vertonen van opportunistisch gedrag en speelt in op begrensde rationaliteit van actoren; dit laatste wordt in dit onderzoek zoals al hiervoor uiteengezet geïnterpreteerd als een dimensie van het beperken van onzekerheid. Geringere onzekerheid en ontmoedigd opportunistisch gedrag dragen bij aan projectsucces (Graafland \& Nijhof, 2007). Onzekerheid en opportunisme kunnen zowel bij opdrachtgever als opdrachtnemer een rol spelen tijdens de aanbesteding en tijdens de samenwerking (na gunning). Vandaar dat in dit onderzoek de effecten van het toepassen van de pips elementen (safeguards) onderzocht worden voor wat betreft het reduceren van onzekerheid en het ontmoedigen van opportunistisch gedrag aan opdrachtgevers- en opdrachtnemerszijde. Daarmee doen we tevens recht aan de definitie van projectsucces (zie verderop in dit hoofdstuk) waarin opgesloten zit dat een project pas succesvol is als er aan beide zijden (opdrachtgever én opdrachtnemer) een zekere mate van tevredenheid bestaat. In schema: 


\section{Overige}

effecten

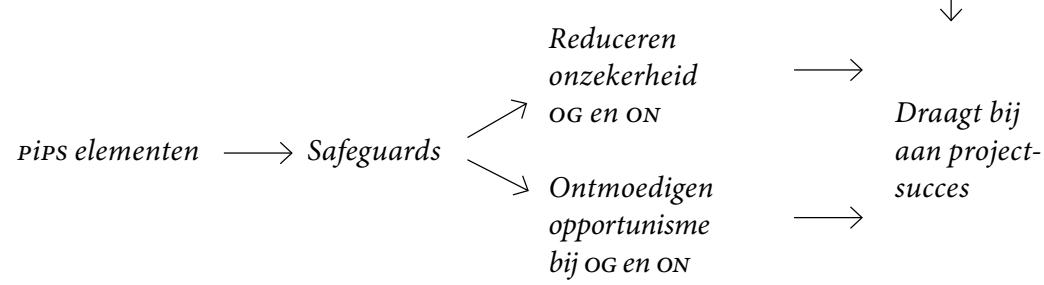

Afbeelding 6.1; Schematische weergave theoretisch model

Onderstaand worden de pips elementen (safeguards) inclusief de daarvoor gehanteerde afkortingen weergegeven zoals die in het vervolg van dit onderzoek worden gebruikt.

\section{pips elementen (safeguards):}

De pips elementen (safeguards), onderverdeeld naar de contact-, contract- en controlfase (tussen haakjes staat de naam waaronder deze elementen verderop in dit hoofdstuk worden aangeduid):

\section{Contactfase:}

- Oplossingsvrij specificeren (Funcspec)

- Maximaal beschikbaar budget vooraf mededelen (Budginf)

- Past performance informatie mee laten wegen (PPI)

\section{Contractfase:}

- Risico's laten duiden en aan laten geven hoe men die denkt te managen (RAVA)

- Sleutelfunctionarissen interviewen en de resultaten daarvan mee laten wegen (Qsleutelf)
- Kwaliteit/prijs verhouding mee laten wegen ( $\mathrm{Pr} / \mathrm{kwal})$

\section{Control fase:}

- Risico's overdragen (Risktrans)

- Performance management o.b.v. harde data (Harddat)

- Performance rating na oplevering (PCR)

Zoals te zien is in de tabellen in bijlage vir is een aantal operationalisaties van onzekerheid en opportunistisch gedrag geformuleerd met behulp waarvan onderzocht is of het toepassen van een bepaalde safeguard volgens geënquêteerden leidt tot reductie van onzekerheid, respectievelijk tot een geringere neiging tot opportunistisch gedrag. Hierbij is zoveel mogelijk aansluiting gezocht bij de grootste gemene deler uit internationale en nationale wetenschappelijke bronnen die in het kader van dit onderzoek zijn bestudeerd (welke bronnen dat zijn wordt telkens tussen haakjes achter de betreffende operationalisatie weergegeven. Dit betreft geen volledige opsomming, maar geeft wel een goed beeld van de belangrijkste bronnen). Behalve de specifiek genoemde bronnen noem ik hier in meer algemene zin de publicatie Revaluing Construction (Barrett, 2007) waarin wordt gememoreerd dat focus op betere samenwerking en op de klantbehoefte in combinatie met gunnen op waarde (in plaats van op de laagste prijs) zal leiden tot een sector waarin meer projecten op tijd, binnen budget en naar tevredenheid zullen worden opgeleverd. Onderstaand worden deze operationalisaties weergegeven.

\section{Onzekerheid aan opdrachtgeverszijde:}

Onzekerheid aan opdrachtgeverszijde is in dit onderzoek als volgt geoperationaliseerd:

- Onzekerheid met betrekking tot de voorspellende waarde van de aanbesteding (Erikson \& Pesamaa, 2007. Zij stellen o.a. dat ervaring en vakbekwaamheid van de leverancier van grote invloed is op projectsucces)

- Onzekerheid met betrekking tot de vraagspecificatie: hebben we gespecificeerd wat nodig is en hebben we dat op een volledige/goede manier gedaan? (Stomp, 2004; Regieraad Bouw, 2005; Scheltema, 2005; Albano \& Cesi, 2008. Zij stellen onder andere dat incomplete specificaties de 
bron vormen van veel onzekerheid);

- Onzekerheid over de contractuele vastlegging (Yates \& Hardcastle, 2003; van den Berg \& Kamminga, 2006. Zij betogen dat 'dichtgetimmerde contracten' schijnzekerheid opleveren en dat meer relationele contracten de samenwerking beter kunnen faciliteren);

- Onzekerheid ten aanzien van onvoorziene gebeurtenissen (Arrow, 1974. Hij stelt dat het bij onvoorziene gebeurteinssen aan komt op vertrouwen om een en ander tot een goed einde te brengen. Tussen vertrouwen en onzekerheid ziet hij een omgekeerd evenredige relatie);

- Onzekerheid ten aanzien van flexibiliteit en coulance bij de opdrachtnemer (sec houden aan contract, of een zekere mate van bereidheid om iets extra's te doen om tot een goede oplossing te komen). (Xiao \& Hua Jin, 2005; Graafland \& Nijhof, 2007. Zij referen aan integere houding en aan commitment om van het project een succes te maken);

- Onzekerheid ten aanzien van het naleven van hetgeen overeen gekomen is. (Graafland \& Nijhof, 2007. Ook deze operationalisatie is gebaseerd op de integriteits overwegingen van Graafland \& Nijhof).

\section{Opportunistisch gedrag aan opdrachtgeverszijde:}

Opportunistisch gedrag aan de zijde van de opdrachtgever is geoperationaliseerd in de vorm van onderstaande manifestaties van opportunistisch gedrag:

- Informatie achterhouden, onjuiste informatie verstrekken (EIв onderzoek "opdrachtgevers aan het woord", 2006; Graafland \& Nijhof 2007. Bij het ЕIB onderzoek wordt het achterhouden van informatie letterlijk als item in de vragenlijst gehanteerd. Graafland \& Nijhof noemen dit aspect als gedragspropositie van niet integer handelen)

- Bewust 'laagste-prijs-klem' gebruiken (Xiao, Hua \& Jin, 2005; Dorée \& Boes, 2007. In beide bronnen worden de ongewenste effecten van het hanteren van de laagste prijsklem uitgewerkt);

- Gebrek aan flexibiliteit, star en onredelijk gedrag (Jin, X \& Ling, 2005. Zij werken het belang van harmonieuze en coöperatieve samenwerking uit als tegenhanger van star en onredelijk gedrag);

- Gebrek aan objectiviteit en transparantie (Geyskens et al, 2006; Graafland \& Nijhof, 2007. Belang van objectiviteit, eerlijkheid en transparante gedragingen, bijvoorbeeld met betrekking tot het beperken van de informatie assymetrie);

- Gebrek aan eerlijkheid, openheid en oprechtheid, het één zeggen en het ander doen (zich niet aan afspraken houden). (Geyskens, et al, 2006 Eerlijkheid en welwillendheid en het zich aan beloften houden worden door deze onderzoekers expliciet genoemd als een belangrijke voorwaarde voor succes)

\section{Onzekerheid aan opdrachtnemerszijde}

Onzekerheid aan opdrachtnemerszijde is in dit onderzoek als volgt geoperationaliseerd:

- Onzekerheid met betrekking tot het kunnen realiseren van een "gezond" rendement (Dorée, 1994; Latham, 1994; Egan, 1998. Deze auteurs betogen en onderbouwen dat te grote economische druk leidt tot een situatie waarin onzekerheid over het te realiseren rendement kan uitmonden in opportunistisch gedrag):

- Taak onzekerheid; nieuwe projecten vragen om nieuwe kennis. Heb ik die in voldoende mate? (Whinch, 1998. Whinch noemt taakonzekerheid expliciet als vorm van onzekerheid (naast geologische, meteorologische en organisatorische onzekerheid) die van invloed is op de performance);

- Onzekerheid over de vraag: heb ik het werk goed ingeschat? (Greenwoord \& Yates, 2006. Zij onderbouwen dat in een vroeg stadium betrekken, mee laten denken en engineeren leidt tot geringere onzekerheid bij opdrachtgevers als het gaat om de vraag of het werk wel goed ingeschat is);

- Organisatorische onzekerheden (hoe pakt de tijdelijke coalitie uit?) (Whinch, 1989. Whinch beschrijft onder andere organisatorische onzekerheid. Hij werkt dat uit in de vorm van 'het functioneren van de tijdelijke coalitie' (lees de projectorganisatie))

- Continuiteitsonzekerheid tijdens de inschrijving (Kreps, 1990; Axelrod 1994, Bresnen \& Marshall, 2000. Als kwaliteit loont (lees van invloed is op winkansen met betrekking tot toekomstig werk) reduceert dat onzekerheid bij opdrachtnemers.);

- Onzekerheid met betrekking tot onvoorziene gebeurtenissen (Arrow, 1974. Arrow werkt dit thema uit in het kader van vertrouwen (in goed acteren in geval van onvoorziene omstandigheden) als tegenhanger van onzekerheid) 
- Onzekerheid als gevolg van een gebrek aan vertrouwen (Goddard \& Mannion, 1998; Geyskens et al, 2006. Deze auteurs noemen het vraagstuk rondom het waarmaken/nakomen van beloftes als vorm van onzekerheid).

\section{Opportunistisch gedrag aan opdrachtnemerszijde:}

Opportunistisch gedrag aan de zijde van de opdrachtnemer is geoperationaliseerd in de vorm van onderstaande manifestaties van opportunistisch gedrag.

- Claim gedrag ('alles' als meerwerk aanmerken, onredelijke prijzen rekenen bij ex post contract onderhandelingen) (Bazerman \&

Samuelson, 1983; Cheung et al, 2005. Zij plaatsen claimgedrag in het kader van opportunistisch gedrag als middel om toch marge te kunnen maken)

- Onvoldoende vakmanschap inzetten (te weinig kwaliteitsgericht) (Boukendour, 2007. Boukendour noemt het inzetten van (te) laag geschoold personeel expliciet als verschijningsvorm van opportunistisch gedrag);

- Star en onredelijk gedrag (bestek letterlijk nemen); confronterende houding. (Williamson, 1985; Yin, X \& Ling, 2005. Zij benoemen

harmonieuze en coöperatieve samenwerking als tegenpool voor star en onredelijk gedrag);

- Gebrek aan coulance, initiatief, meedenken, flexibiliteit, optimalisaties, service zonder daarvoor meteen compensatie te willen hebben (Geyskens et al, 2006. Zij werken deze vorm van opportunistisch gedrag uit als een tekort aan 'welwillendheid en hulpvaardigheid');

- Gebrek aan eerlijkheid, openheid, oprechtheid, het één zeggen en het ander doen (zich niet aan afspraken houden) (Geyskens et al, 2006. Zij werken deze vorm van opportunistisch gedrag uit als een tekort aan eerlijkheid en het 'woord houden');

- Fouten verhullen en onvoldoende bereid zijn ze behoorlijk te herstellen (Williamson, 1985; EIB, 2006. Williamson operationaliseert deze vorm van opportunistisch gedrag in de vorm van 'zich ergens makkelijk van af maken'. In het EIB onderzoek 'Opdrachtgevers aan het woord' wordt het correct oplossen van problemen evenals het afhandelen van klachten als operationalisatie van deze vorm van opportunistisch gedrag genoemd en gemeten);

- "Gaten" in het bestek zo gunstig mogelijk (voor het eigen belang) uitspelen (Graafland \& Nijhof, 2007. Deze auteurs scharen het niet of niet tijdig delen van informatie zoals tekortkomingen in de uitvraag onder de noemer integriteit)

- Bewust laag inschrijven en daarna via her onderhandelingen voordelen binnenhalen (Ling \& Kumaraswamy, 2005. Deze auteurs plaatsen deze werkwijze onder de noemer 'er worden geen spelletjes gespeeld').

\section{Projectsucces:}

Voor de term projectsucces wordt in dit onderzoek de volgende definitie gehanteerd: een project is succesvol als beoogde resultaten tijdig en binnen budget opgeleverd worden en er op een harmonieuze en coöperatieve wijze is samengewerkt naar tevredenheid van opdrachtgever en opdrachtnemer(s) (vrije vertaling naar Jin, \& Ling, 2005).

\section{Onderzoeksopzet nader geconcretiseerd:}

Met behulp van de hiervoor weergegeven operationalisaties kan het model van afbeelding 6.1 nader worden geconcretiseerd zodat de onderzoeksopzet verduidelijkt wordt: 
Pips

safeguards:

- Funcspec

- Budginf

- PPI

- RAP

- Qsleutelf

- $\mathrm{Pr} / \mathrm{kwal}$

- Risktrans

- Harddat

- PCR
Minder onzekerheid og t.a.v:

- Voorspellende waarde

aanbesteding

- Vraagspecificatie

- Contractuele vastlegging

- Onvoorziene gebeurtenissen

- Coulance en flexibiliteit

- Vertrouwen in naleving door partij

Minder onzekerheid on t.a.v:

- Faire marge

- Berekend op taak?

- Inschatting van het werk

- Functioneren project organisatie

- Kans op werk

- Onvoorziene gebeurtenissen

- Onderling vertrouwen

Ontmoedigd opportunisme OG t.a.v:

- Achterhouden informatie

- Laagste-prijs-klem gedrag

- Star en onredelijk gedrag

- Objectiviteit en transparanti

- Eerlijkheid en openheid

Ontmoedigd opportunisme ON t.a.v:

- Claim gedrag en

- Inzet laaggeschoold personeel

- Confronterende houding

- Initiatief en meedenken

- Gebrek aan open en eerlijke houding

- Fouten herstellen

- "Gaten in het bestek" uitspelen

- "Strategisch inschrijven"
Bijdrage aan projectsucces; binnen planning en budget en naar tevredenheid van opdrachtgever en opdrachtnemer opleveren van beoogde resultaten.
Opzet online-enqûete

Confrontaties tussen safeguards en operationalisaties die duidelijke verbanden opleveren en zodoende bij kunnen dragen aan de validatie waarnaar we in dit kwantitatief onderzoek op zoek zijn ${ }^{83}$, zijn vertaald naar enquêtevragen. Confrontaties die niet tot toetsbare combinatie leiden zijn niet uitgewerkt in vragen. Praktische overweging daarvoo is de lengte van de vragenlijst te willen beperken. Ook vragen die tevee overlap vertonen met wel al opgenomen vragen, zijn niet opgenomen ook hier prevaleert de praktische overweging ten aanzien van de lengte van de vragenlijst. Zie bijlage viI voor de matrici waarin deze confrontaties zijn uitgewerkt. Onder deze matrici wordt kort verantwoord waarom bepaalde combinaties niet tot een vraag in de enquête hebben geleid, en andere wel.

Er staan 4 vragen centraal bij deze enquête:

vraag 1 Reduceert het gebruik van pips safeguards onzekerheid voor opdrachtgevers, volgens opdrachtgevers?

vraag 2 Reduceert het gebruik van pips safeguards onzekerheid voor opdrachtnemers, volgens opdrachtnemers?

vraag 3 Ontmoedigt het gebruik van pips safeguards opportunistisch gedrag van opdrachtnemers volgens opdrachtgevers?

vraag 4 Ontmoedigt het gebruik van pips safeguards opportunistisch gedrag van opdrachtgevers volgens opdrachtnemers?

Er zijn twee aparte enquêtes uitgewerkt. Één enquête specifiek gerich op opdrachtgevers (vraag een en drie; PiPsog), de andere op opdrachtnemers (vraag twee en vier; pipson). Voorafgaand aan de vragen over onzekerheid en opportunisme is een aantal vragen opgenomen met het oogmerk achteraf te kunnen categoriseren en aan de hand daarvan
${ }^{83}$ Verwacht 'de praktijk' inderdaad effecten van het toepassen van pips elementen zoals die ook verwacht worden door het op NIE gebaseerde theoretische model? 
diverse dwarsdoorsneden te maken. Respondenten met een bedrijfskundige achtergrond zouden bijvoorbeeld anders over bepaalde zaken kunnen denken dan respondenten met een technische achtergrond.

De laatste vraag in deze categorie gaat in op de mate van ervaring die respondenten hebben met bepaalde innovatieve elementen (pips safeguards). Daardoor weten we of een bepaalde respondent antwoordt vanuit feitelijke ervaring, of dat zijn antwoord meer gebaseerd is op algemene beelden, verwachtingen. Bijlage xi geeft inzicht in de uitgewerkte enquête vragen voor opdrachtgevers en opdrachtnemers.

De enquête is uitgewerkt in QMP (Question Mark Perception). Dit is de standaard tool die binnen Zuyd Hogeschool wordt gehanteerd voor dit soort online-enquêtes. Daarnaast was een belangrijke overweging dat er voldoende support beschikbaar is als het gaat om de technische kant van het online onderzoek. De enquête voor de opdrachtgevers is 26 juni 2009 verstuurd aan 134 projectleiders. Van negen projectleiders bleek ofwel het adres niet te kloppen, ofwel ze waren van baan veranderd. Aan 125 projectleiders aan opdrachtgeverszijde is dus uiteindelijk gevraagd de enquête in te vullen. Aan opdrachtnemerszijde is de enquête uitgezet naar 97 projectleiders.

\section{Op wie richt het onderzoek zich?}

Omdat de effecten van de pips safeguards voor wat betreft gereduceerde onzekerheid en ontmoedigd opportunisme bij opdrachtgevers en opdrachtnemers onderzocht worden, zijn vertegenwoordigers van beide 'partijen' bevraagd. Zowel bij opdrachtgevers als bij opdrachtnemers richt dit onderzoek zich op projectleiders die zowel betrokken zijn bij aanbestedingen van werken als bij de uitvoering daarvan. Reden hiervoor is dat zowel tijdens de ex ante- als ex post contractfase onzekerheid en opportunisme een rol kunnen spelen en beïnvloed kunnen worden door de pips safeguards.

Aan opdrachtgeverszijde zijn Rijkswaterstaat, UMC St Radboud en enkele grotere gemeenten (Den Haag, Rotterdam, Tilburg,

's-Hertogenbosch) benaderd. Deze keuze is gemaakt vanwege het feit dat deze partijen meer dan gemiddeld actief zijn op het gebied van 'vernieuwend aanbesteden'. Op grond daarvan verwachten we bij deze organisaties projectleiders aan te treffen die enigszins bekend zijn met en ervaring hebben met innovatieve elementen die in dit onderzoek aan de orde komen. We willen immers theoretische redeneringen omtrent de werking van deze elementen toetsen aan heersende praktijkinzichten. Zoals hiervoor al gemeld is 125 projectleiders uit deze gerichte steekproef gevraagd de enquête in te vullen.

Aan opdrachtnemerszijde zijn in eerste instantie 42 infra bedrijven benaderd via Bouwend Nederland, daarnaast zijn Bam Utiliteitsbouw en Heijmans separaat benaderd. Het verkrijgen van voldoende projectleiders die benaderd konden worden om de online-enquête in te vullen verliep aan opdrachtnemerszijde opvallend lastig en stroef, vergeleken met het verloop hiervan bij de opdrachtgevers. Bovenstaande actie leverde niet meer dan 13 bruikbare e-mail adressen op. Daarna zijn de deelnemers aan opdrachtgeverszijde benaderd met het verzoek enkele e-mail adressen van projectleiders uit hun netwerk aan te willen reiken. Deze actie in combinatie met een herhaald verzoek onder de leden van het aanbestedingsteam dat verantwoordeliik is voor de aanbesteding van het bergbezinkbassin in de gemeente 's-Hertogenbosch, leverde uiteindelijk 97 bruikbare e-mail adressen op.

\subsection{Onderzoeksresultaten, verwerking en analyse}

In deze paragraaf worden de onderzoeksresultaten weergegeven, verwerkt en nader genalayseerd. Ingezoomd wordt op de respons (kwalitatief en kwantitatief), de manier waarop de data is verwerkt en bewerkt. Ook de uitgevoerde statistische analyses worden behandeld. Naast een gedetailleerde weergave van de resultaten (in de vorm van de tabellen die de verbanden weergeven tussen de safeguards en de effecten op de operationalisatie van onzekerheid en opportunisme) worden de resultaten ook op meer geabstraheerde aggregatieniveaus behandeld.

\section{Respons}

De online-enquête aan opdrachtgeverszijde leverde een bruikbare respons op van 38 stuks, zijnde $30,4 \%$ van de 125 projectleiders die de uitnodiging tot deelname hebben ontvangen. Het totale aantal respondenten bedroeg 72 . Een grote groep daarvan heeft echter na het openen van de enquête de keuze gemaakt toch niet in te vullen, of dat 
slechts voor maar een klein deel te doen. Een mogelijke verklaring hiervoor kan zijn dat deze groep zichzelf niet in staat achtte de enquête gericht in te kunnen vullen. Deze groep respondenten is dan ook bij de verdere uitwerking buiten beschouwing gelaten.

Bij de opdrachtnemers hebben 47 van de 97 uitgenodigde projectleiders deelgenomen aan de online-enquête; dit komt neer op 48,5\%. Deze respondenten hebben de enquête allen nagenoeg geheel ingevuld.

Qua samenstelling van de respondentgroepen geldt voor beide groepen (PiPSOG en PiPSON) dat de GWW sector dominant aanwezig is, en dat uit andere sectoren (woningbouw, utiliteitsbouw) slechts enkele respondenten vertegenwoordigd zijn. Ook geldt voor beide groepen dat deelnemers die meer dan 10 jaar ervaring hebben dominant vertegenwoordigd zijn. Zowel opdrachtgevers als opdrachtnemers hebben aangegeven overwegend actief te zijn in het publieke domein. De achtergrond van respondenten is overwegend technisch (bouw/civiel gerelateerd) van aard. Bedrijfskundige en juridische achtergronden komen niet veel voor onder de respondenten. Onderstaande tabellen geven inzicht in de kenmerken van de respondenten.

\begin{tabular}{lllll} 
& Woningbouw & U-bouw & GWW & totaal \\
OG $(38)$ & $2 \%$ & - & & \\
ON $(47)$ & $0 \%$ & $21 \%$ & $78 \%$ & $100 \%$ \\
& & & $70 \%$ & $100 \%$ \\
\hline
\end{tabular}

Tabel 6.1; Verdeling respondenten naar sector

\begin{tabular}{llllll}
\hline & & & & \\
& & & & & \\
& & & & & \\
jaar & & & & & \\
OG $(38)$ & $15 \%$ & $20 \%$ & $36 \%$ & jaar & totaal \\
ON $(47)$ & $6 \%$ & $9 \%$ & $30 \%$ & $29 \%$ & $100 \%$ \\
& & & $55 \%$ & $100 \%$ \\
\hline
\end{tabular}

Tabel 6.2; Verdeling respondenten naar ervaringscategorie

\section{Publiek domein Private domein totaa}

$\begin{array}{llll}\text { OG (38) } & 93 \% & 7 \% & 100 \% \\ \text { ON (47) } & 75 \% & 25 \% & 100 \%\end{array}$

Tabel 6.3; Verdeling respondenten naar publieke en private domein

\begin{tabular}{llllll}
\hline & $\begin{array}{l}\text { (Bouw) } \\
\text { technisch }\end{array}$ & Bedrijfskundig & Juridisch & Overig & totaal \\
OG $(38)$ & $71 \%$ & $17 \%$ & - & $12 \%$ & $100 \%$ \\
ON $(47)$ & $90 \%$ & $9 \%$ & - & $1 \%$ & $100 \%$ \\
\hline
\end{tabular}

Tabel 6.4; Verdeling respondenten naar achtergrond

De verdeling van respondenten over de verschillende categorieën is zodanig dat telkens eén categorie sterk vertegenwoordigd is ${ }^{84}$, terwill de overige categorieën maar geringe aantallen respondenten bevatten. Statistische toetsen als verschillen analyses tussen deze categorieën zijn hieromtrent dan ook weinig zinvol. De antwoorden zouden een te geringe mate van betrouwbaarheid hebben; het aantal waarnemingen in één cel is te gering om tot betrouwbare uitspraken te kunnen komen.
${ }^{84}$ Bij ervaringsjaren zijn dit twee naast elkaar gelegen categorieën. 
Naast bovenstaande categoriserende vragen is ook gevraagd naar de mate van ervaring die respondenten hebben met de innovatieve elementen die we onderzoeken op hun invloed op het reduceren van onzekerheid en het ontmoedigen van opportunisme. Respondenten hebben hierbij geantwoord in vier categorieën:

- Geen ervaring

- Nauwelijks ervaring

- Regelmatig ervaring

- Veel ervaring

Vanwege het geringe aantal respondenten per categorie, worden deze

${ }^{85}$ Dit om te voorkomen dat er cellen ontstaan die scores weergeven die op dermate weinig respondenten

betrekking hebben, dat onderzoeksresultaten onvoldoende betrouwbaar zijn.

\begin{tabular}{lll|ll}
\hline & \multicolumn{2}{c|}{ Opdrachtgevers } & \multicolumn{2}{c}{ Opdrachtnemers } \\
& Geen/nauwelijks & Regelmatig/veel & Geen/nauwelijks & Regelmatig/veel \\
Funcspec & $44 \%(18)$ & $56 \%(23)$ & $59 \%(27)$ & $41 \%(19)$ \\
Budginf & $88 \%(36)$ & $12 \%(5)$ & $89 \%(42)$ & $11 \%(5)$ \\
PPI & $80 \%(33)$ & $20 \%(8)$ & $45 \%(21)$ & $55 \%(26)$ \\
RAVA & $48 \%(19)$ & $52 \%(21)$ & $49 \%(23)$ & $51 \%(24)$ \\
Qsleutelf & $87 \%(35)$ & $13 \%(5)$ & $70 \%(33)$ & $30 \%(14)$ \\
Pr/kwal & $33 \%(13)$ & $67 \%(27)$ & $43 \%(20)$ & $57 \%(27)$ \\
Risktrans & $38 \%(15)$ & $62 \%(24)$ & $52 \%(24)$ & $48 \%(23)$ \\
Harddat & $68 \%(28)$ & $32 \%(13)$ & $80 \%(36)$ & $20 \%(9)$ \\
PCR & $88 \%(36)$ & $12 \%(5)$ & $94 \%(44)$ & $6 \%(3)$ \\
\hline
\end{tabular}

Tabel 6.5; Procentuele verdeling mate van ervaring met PiPs elementen PiPSOG en PiPSON

De mate van ervaring die opdrachtgevers en opdrachtnemers hebben met deze elementen, vertoont voor acht van de negen elementen grote overeenkomst. Alleen voor wat betreft het toepassen van past performance information (PPI) verschillen de antwoorden opvallend. $80 \%$ van de respondenten onder de opdrachtgevers geeft aan daar geen of nauwelijks ervaring mee te hebben, terwijl $55 \%$ van de respondenten onder de opdrachtnemers zegt er wel ervaring mee te hebben. Een mogelijke verklaring hiervoor zit hem in interpretatieverschillen: Opdrachtgevers hebben PPI mogelijk echt als zodanig opgevat (dus 
niet alleen 'marketinginfo' over het gerealiseerde resultaat inleveren, maar ook inzicht geven in het procesverloop), terwijl opdrachtnemers het opgeven van referenties daar ook onder geschaard lijken te hebben. Ook het feit dat $25 \%$ van de geënqûeteerde opdrachtnemers overwegend actief is voor private opdrachtgevers (terwijl deze categorie nauwelijks deel uit maakt van de respondenten) kan een deel van de verklaring vormen; private opdrachtgevers zouden PPI al meer en breder kunnen toepassen dan publieke.

Verder valt op dat $69 \%$ van de opdrachtgevers aangeeft weinig ervaring te hebben met het besturen van projecten met behulp van harde performance data. Een opmerkelijke score; de belangen zijn vaak groot en er zijn vele lessons learned beschikbaar die aantonen dat monitoren

van het bouwproces nodig is om op tijd, binnen budget en naar tevredenheid te kunnen beschikken over het gebouwde (Takim \& Akintoye, 2002; Ang, Groosman en Scholten, 2005). Ook het delen van informatie over het maximaal beschikbare budget dat aangewend zal worden in een onderhavige aanbesteding vormt nog een grote uitzondering. Datzelfde geldt voor het mee laten wegen van de kwaliteit van sleutelfunctionarissen. Algemeen wordt erkend (zoals besproken in hoofdstuk twee en drie) dat een projectleider een stevig stempel op een projectverloop en resultaat kan drukken (Waara, 2008). Bij het selecteren/ contracteren van de partij aan wie het werk gegund zal worden, wordt met dit aspect in de praktijk nog maar weinig rekening gehouden. De verdeling van de respondenten over geen en nauwelijks ervaring enerzijds en regelmatig en veel ervaring anderszijds, biedt wel aanknopingspunten om te onderzoeken of respondenten die antwoorden op basis van ervaring anders (wellicht positiever) scoren dan respondenten met geen/nauwelijks ervaring. Deze toetsen komen verderop aan de orde.

Het aantal respondenten ten opzichte van het aantal uitgenodigde deelnemers valt met respectievelijk $30 \%$ en $48 \%$ binnen een bandbreedte die bij dit soort onderzoeken veel voorkomt. Het percentage respondenten bij de opdrachtnemers is zelfs aan de hoge kant.

$\mathrm{Na}$ de vragen die betrekking hebben op achtergrond en ervaring hebben respondenten van een aantal stellingen met betrekking tot 'onzekerheid' en 'opportunisme' aangegeven in welke mate ze het daarmee eens danwel oneens zijn. Daarvoor zijn zogenaamde matrixvragen gecon-
1 Helemaal oneens

Grotendeels oneens

Enigszins oneens

Enigszins eens

Grotendeels eens

6 Helemaal eens

Deze matrixvragen bestaan uit een statement dat handelt over een van de onderzochte pips safeguard/elementen, met daarachter een aantal uitspraken (de operationalisaties van onzekerheid respectievelijk opportunisme zoals eerder in dit hoofdstuk uitgewerkt). Deze matrixvragen zijn zoals eerder al aangegeven geconstrueerd volgens een if/than statement. Onderstaand een voorbeeld van een dergelijke matrixvraag (zie bijlage XI voor de gehele online-enqûete).

Als opdrachtgevers naast prijs ook kwaliteit mee wegen bij het aanbesteden van werk,

1. zie ik meer mogelijkheden een gezond rendement te kunnen maken

2. ben ik minder onzeker over het functioneren van de projectorganisatie

. maakt dat die aanbesteding voor mij minder onzeker

4. kan ik makkelijker inspelen op onvoorziene gebeurtenissen

5. heb ik meer vertrouwen in een goede afloop van dat project

Respondenten hebben aan deze statements (voorbeeld van 1 t $/ \mathrm{m} 5$ ) een score toegekend op de schaal van een tot en met 6 . Bij de verwerking van de data is de keuze gemaakt om te focussen op de samengestelde scores per enqûetevraag; Dit zijn immers de vragen die centraal staan bij dit onderzoek. De operationalisaties hebben slechts de functie om onzekerheid respectievelijk opportunisme hanteerbaar te maken voor respondenten. Hierna wordt verder ingegaan op de verwerking van 


\section{de aldus verzamelde data en de resultaten die dat heeft opgeleverd.}

\section{Verwerking van de data}

Nadat de onderzoeken afgesloten zijn, is zowel voor pipsog als voor PisPon een datamatrix samengesteld in Excel (standaardfunctie binnen QMP). Daarbij zijn, zoals al eerder aangegeven, respondenten die slechts een zeer gering deel van de enquête ingevuld hebben verwijderd, zijn vragen omgepoold waarbij dat aangewezen was (zie bijlage XI waarin omgepoolde vragen vet worden weergegeven). De aldus ontstane datamatrix is vervolgens ingelezen in sPss (aanvankelijk versie 16, later in versie 18) waarna de variabelen gelabeld en gecodeerd zijn.

Van de individuele itemscores per vraag zijn gemiddelden berekend, deze gemiddelden per vraag zijn vervolgens als nieuwe variabelen gehanteerd om statistische bewerkingen mee uit te voeren. Deze keuze is gemaakt omdat (zoals hierboven ook al vermeld) met deze onlineenqûete beoogd wordt te toetsen of de praktijkinzichten ten aanzien van de effecten van de pips safeguards op het reduceren van onzekerheid respectievelijk het ontmoedigen van opportunistisch gedrag overeenstemmen met de theoretische redeneringen daaromtrent. Om deze reden dient de toetsing plaats te vinden op het samengesteld niveau van de matrixvragen. Voorwaarde hierbij is dat van voldoende homogeniteit binnen de matrixvragen sprake is. De daarvoor geschikte toetsen (Cronbach's $\alpha$ ) zijn uitgevoerd waarover later meer. De waarden in onderstaande tabel hebben betrekking op de aldus geconstrueerde variabelen ${ }^{87}$. Voor deze geconstrueerde variabelen is niet de interval

${ }^{87}$ Vandaar ook dat de mediaan en eerste en derde kwartiel waarden geen hele getallen zijn. schaal (van $1 \mathrm{t} / \mathrm{m} 6)$ van toepassing maar een continuschaal van een tot en met zes. Bij de geconstrueerde variabelen komen dan ook vooral de tussenliggende decimale getallen voor doordat ze ontstaan zijn door berekening van de samengestelde scores van de onderliggende individuele operationalisaties van onzekerheid respectievelijk opportunisme.

De aanname is gedaan dat wanneer een geconstrueerde variabele 3,5 (het midden van de schaal 1-6) of hoger scoort dit betekent dat het betreffende statement (dat gekoppeld is aan een pips safeguard) een bijdrage levert aan het reduceren van onzekerheid respectievelijk het ontmoedigen van opportunistisch gedrag. Cellen die betrekking hebben op pips elementen die hoger dan $3,5(\mu>3,5)$ scoren zijn gearceerd weergegeven in tabellen 6.6 en 6.7

Op de eerste plaats richten de statistische bewerkingen zich op de algemene tendenties zoals die in de volgende tabellen voor respectieve-

lijk pipsog en pipson worden weergegeven. In deze tabellen ook aandacht voor de interne homogeniteit van de items per vraag. Dit wordt in de meest rechtse kolom weergegeven door de Cronbach's $\alpha^{88}$.

De overige kolommen:

- $\mathrm{n}$ staat voor het aantal respondenten

- $\mu$ staat voor de gemiddelde score

- $\sigma$ staat voor standaarddeviatie

- $25 \%$ staat voor eerste kwartiel, links van de mediaan

- $50 \%$ staat voor de mediaan (middelste waarde)

- $75 \%$ staat voor derde kwartiel, rechts van de mediaan
${ }^{88}$ Cronbach's $\alpha$ is een statistische maat voor de interne homogeniteit van samengestelde vragen. Deze interne homogeniteit moet boven de 0,7 liggen en vormt daarmee een voorwaarde

voor validiteit van de meting. 


\begin{tabular}{|c|c|c|c|c|c|c|c|}
\hline Vraag & $\mathbf{n}$ & $\mu$ & $\sigma$ & $25 \%$ & $50 \%$ & $75 \%$ & $a$ \\
\hline Funcspec & 41 & 3,61 & 0,770 & 3,17 & 3,67 & 4,08 & 0,696 \\
\hline PPI & 38 & 3,98 & 0,703 & 3,60 & 4,00 & 4,40 & 0,754 \\
\hline RAP & 38 & 4,37 & 0,869 & 4,00 & 4,50 & 5,00 & 0,872 \\
\hline Qsleutelf & 37 & 4,39 & 0,944 & 3,88 & 4,75 & 5,00 & 0,924 \\
\hline $\operatorname{Pr} /$ kwal & 38 & 4,22 & 0,899 & 3,67 & 4,33 & 5,00 & 0,950 \\
\hline Risktrans & 37 & 4,32 & 1,032 & 3,80 & 4,40 & 5,00 & 0,911 \\
\hline PCR & 38 & 3,83 & 0,989 & 3,15 & 4,00 & 4,40 & 0,902 \\
\hline Harddat & 39 & 4,32 & 0,739 & 3,67 & 4,33 & 5,00 & $0,650^{*}$ \\
\hline Onz gem & & 4,067 & 0,641 & 3,62 & 4,17 & 4,56 & 0,834 \\
\hline Funcspec & 31 & 3,59 & 0,852 & 3,00 & 3,40 & 4,20 & 0,794 \\
\hline Budginf & 30 & 3,60 & 1,155 & 3,00 & 3,75 & 4,31 & 0,939 \\
\hline PPI & 27 & 3,79 & 0,893 & 3,00 & 4,00 & 4,33 & 0,962 \\
\hline RAP & 30 & 3,90 & 0,916 & 3,00 & 4,00 & 4,56 & 0,895 \\
\hline Qsleutelf & 28 & 3,99 & 0,765 & 3,50 & 4,00 & 4,50 & 0,926 \\
\hline $\operatorname{Pr} /$ kwal & 30 & 3,88 & 0,847 & 3,40 & 3,83 & 4,54 & 0,933 \\
\hline Risktrans & 28 & 4,10 & 0,692 & 3,31 & 4,00 & 4,75 & 0,874 \\
\hline PCR & 29 & 4,14 & 0,803 & 3,41 & 4,00 & 5,00 & 0,951 \\
\hline Harddat & 29 & 3,73 & 0,905 & 3,00 & 3,83 & 4,17 & 0,942 \\
\hline Opp gem & & 3,81 & 0,673 & 3,30 & 3,80 & 4,30 & 0,931 \\
\hline
\end{tabular}

slechts tot geringe

verhoging. Het ver-

lies van data weegt

daar niet tegen op.

\begin{tabular}{|c|c|c|c|c|c|c|c|}
\hline Vraag & $\mathbf{n}$ & $\mu$ & $\sigma$ & $25 \%$ & $50 \%$ & $75 \%$ & $\alpha$ \\
\hline Funcspec & 47 & 4,15 & 0,842 & 3,67 & 4,17 & 4,83 & 0,788 \\
\hline Budginf & 47 & 3,56 & 1,006 & 2,75 & 3,75 & 4,25 & 0,839 \\
\hline PPI & 47 & 3,91 & 1,067 & 3,29 & 4,00 & 4,71 & 0,949 \\
\hline RAP & 47 & 4,40 & 0,890 & 3,86 & 4,43 & 5,00 & 0,921 \\
\hline Qsleutelf & 46 & 3,87 & 0,917 & 3,29 & 3,92 & 4,71 & 0,893 \\
\hline $\operatorname{Pr} /$ kwal & 47 & 4,71 & 0,634 & 4,40 & 4,60 & 5,00 & $0,658^{*}$ \\
\hline Risktrans & 47 & 4,10 & 0,645 & 3,83 & 4,00 & 4,50 & $0,589^{*}$ \\
\hline Onz gem & & 4,103 & 0,561 & 3,63 & 4,17 & 4,57 & 0,757 \\
\hline Funcspec & 46 & 3,10 & 0,602 & 3,00 & 3,00 & 3,50 & $* *$ \\
\hline Budginf & 46 & 2,89 & 0,699 & 2,50 & 3,00 & 3,50 & $* *$ \\
\hline PPI & 46 & 3,27 & 0,987 & 3,00 & 3,00 & 4,00 & $* *$ \\
\hline Qsleutelf & 46 & 3,16 & 0,961 & 2,50 & 3,00 & 4,00 & $* *$ \\
\hline $\mathrm{Pr} / \mathrm{kwal}$ & 46 & 3,35 & 1,100 & 3,00 & 3,00 & 4,00 & $* *$ \\
\hline Risktrans & 46 & 3,23 & 0,763 & 2,67 & 3,00 & 3,67 & $* *$ \\
\hline Opp gem & & 3,17 & 0,638 & 2,86 & 3,08 & 3,42 & 0,840 \\
\hline
\end{tabular}


* Deze beide waardes duiden op beperkte interne

homogeniteit.

Laten vervallen van

deze items (oo6A

en $007 \mathrm{~F}$ ) verhoogt niet noemenswaardig en impliceert dataverlies.

** Aantal items per vraag is te gering om afzonderlijke $a$ per item te berekenen.

Vandaar dat hier alleen de a voor de hele set vragen die

betrekking hebben op het ontmoedigen van opportunisme wordt weergegeven.

De scores van Pipsog respondenten op de vragen over het reduceren van onzekerheid en het ontmoedigen van opportunisme, worden onderstaand weergegeven in de vorm van boxplots (afbeelding $6.3 \mathrm{en}$ 6.4). Daarna volgen twee figuren met boxplots die weergeven hoe de safeguards scoren op onzekerheid en opportunisme in de pipson meting (afbeelding 6.5 en 6.6). De vier afgebeelde boxplots bevatten een grafische weergave van de $25 \%, 50 \%$ en $75 \%$ kolommen uit de vorige twee tabellen. De $25 \%$ en $75 \%$ waarden vormen de respectievelijke linker en rechter begrenzing van de boxen. De 50\% waarde is door middel van een enkele lijn weergegeven. Het gedeelte tussen 3,5 en 6 heeft een grijs blok gekregen om te verduidelijken dat de waardes die in dit gebied liggen bijdragen aan de veronderstelde reductie van onzekerheid respectievelijk het ontmoedigen van de neiging tot opportunistisch gedrag. Wat meteen opvalt, is dat bij de eerste drie afbeeldingen de scores voor het overgrote deel binnen dit gebied vallen, terwijl dit bij de vierde afbeelding juist andersom is.

Funcspec

Budginf

PPI

RAP

Qsleutelf

$\mathrm{Pr} / \mathrm{kwal}$

Risktrans
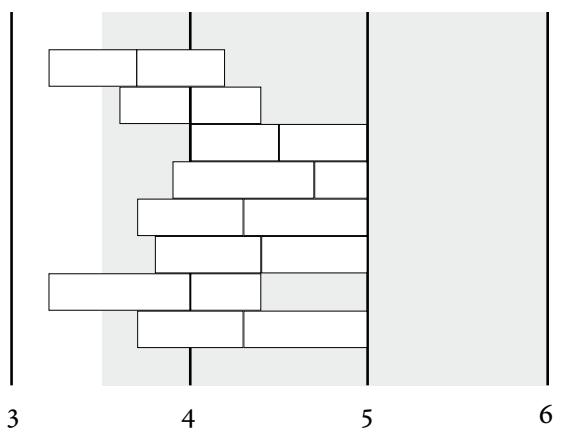

Afbeelding 6.3; Boxplots van PiPSOG scores safeguards met betrekking tot het reduceren van onzekerheid

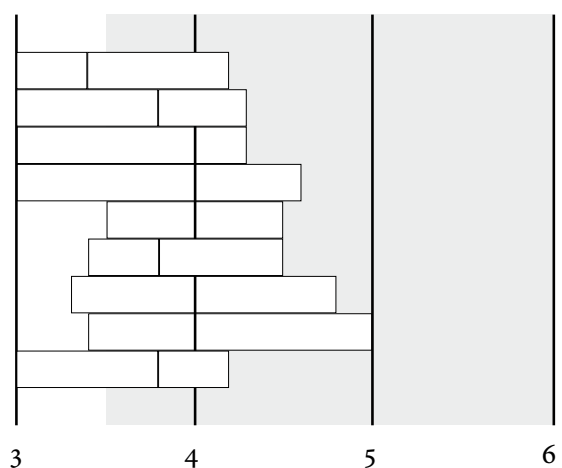

Afbeelding 6.4; Boxplots van PiPSOG scores safeguards met betrekking tot ontmoedigen van opportunisme

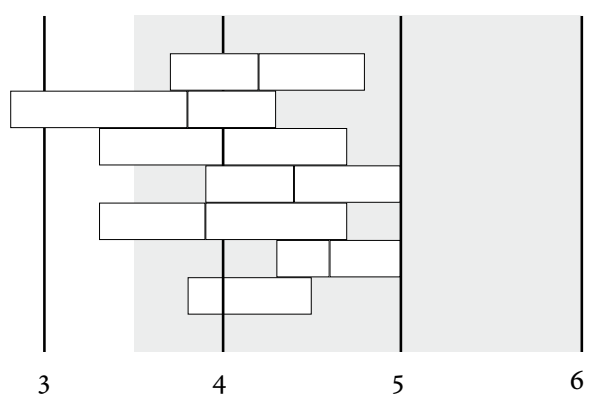

Afbeelding 6.5; Boxplots van PiPSON scores safguards me betrekking tot reduceren van onzekerheid 
Funcspec

Budginf

PPI

RAP

Qsleutelf

Pr/kwal

Risktrans

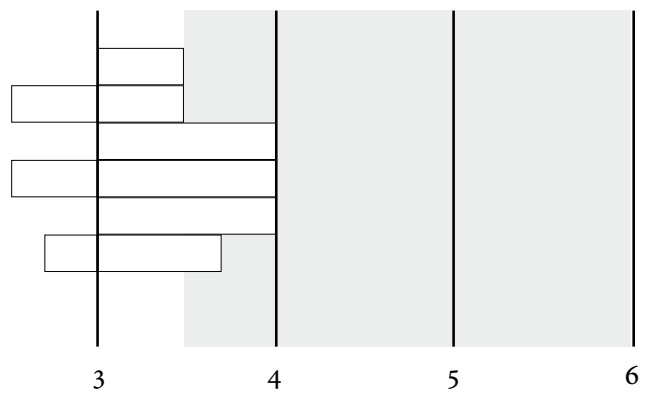

Afbeelding 6.6; Boxplots van PiPSON scores safgeguards met betrekking tot het ontmoedigen van opportunisme

Nadere beschouwing van deze boxplots maakt inzichtelijk dat alle pips elementen volgens respondenten aan opdrachtgeverszijde bijdragen aan het reduceren van onzekerheid. Dat geldt tevens voor het ontmoedigen van opportunistisch gedrag (met uitzondering van Funcspec waarvan de 50\% waarde (de mediaan) net buiten het grijze gebied ligt). Opdrachtnemers geven aan dat alle pips elementen volgens hen bijdragen aan het reduceren van onzekerheid voor henzelf. Tot slot geven respondenten van de zijde van de opdrachtnemers aan dat ze niet van mening zijn dat toepassing van pips elementen opportunistisch gedrag van opdrachtgevers zal ontmoedigen; het antwoord patroon is eerder neutraal te noemen.

Kijkend naar de effectiviteit van de verschillende pips elementen zijn de verschillen doorgaans gering binnen elk van de vier centrale vragen. Bij de eerste drie boxplots liggen de meeste antwoorden tussen de 3,5 en de 4.5. Bij de vierde boxplot liggen de meeste antwoorden tussen de 3,0 en 4,0 . Verder inzoomen op de geringe verschillen in effectiviteit van de verschillende pips safeguards levert naar verwachting weinig bruikbare inzichten op in het kader van het beantwoorden van de hoofdvraag van dit kwantitatief onderzoek.

Het lijkt wel interessant te bezien of en in welke mate respondenten met regelmatig/veel ervaring anders scoren ten opzichte van respondenten zonder/met nauwelijks ervaring. Dit is interessant omdat de respondenten werkzaam zijn bij opdrachtgevers die bovengemiddeld actief zijn met innovatief aanbesteden. Voor een groot deel van de respondenten van de opdrachtnemers enquête geldt dat deze werkzaam zijn bij bedrijven die voor de geënquêteerde opdrachtgevers werken. Indien zou blijken dat respondenten met minder ervaring in vergelijkbare mate scoren als respondenten met veel ervaring, is de redenering dat onderzoeksuitkomsten in grotere mate generaliseerbaar zijn dan wanneer er duidelijke verschillen zichtbaar worden tussen respondenten met weinig ervaring ten opzichte van respondenten met veel ervaring.

Om dat te onderzoeken zijn (independent samples) т tests uitgevoerd waarbij zowel binnen PiPSOG als binnen PiPson twee categorieen respondenten zijn onderscheiden: respondenten met geen/nauwelijks ("minder ervaring") ervaring enerzijds en respondenten met regelmatig/veel ("meer ervaring") ervaring anderzijds. Zowel binnen pipsog als binnen pipson zijn deze tests apart uitgevoerd voor onzekerheid en opportunisme. Deze tests leveren het inzicht op of respondenten met weinig ervaring significant anders hebben geantwoord dan respondenten met veel ervaring. De op de volgende pagina afgebeelde tabel geeft inzich in de uitkomsten. De getallen tussen haakjes geven de aantallen antwoorden (n) weer. 
PiPSOG: Verschillen tussen antwoorden van categorieën minder \& meer ervaring

Gemiddelde antwoorden m.b.t. effecten op het reduceren van onzekerheid

$\begin{array}{llll}\text { Elementen } & \begin{array}{l}\text { Gemiddeld } \\ \text { antwoord } \\ \text { ervaring } \\ \text { minder }\end{array} & \begin{array}{l}\text { Gemiddeld } \\ \text { antwoord } \\ \text { ervaring } \\ \text { meer }\end{array} & \begin{array}{l}\text { Significantie } \\ (\mathrm{p} \leq 0,05)\end{array} \\ \text { Funcspec } & 3,89(18) & 3,38(23) & 0,032 \\ \text { PPI } & 3,97(32) & 4,07(6) & 0,759 \\ \text { RAVA } & 4,40(17) & 4,37(20) & 0,905 \\ \text { Qsleutelf } & 4,37(32) & 4,63(4) & 0,618 \\ \text { Pr/kwal } & 4,46(15) & 4,09(24) & 0,242 \\ \text { Risktrans } & 4,76(15) & 4,07(21) & 0,043 \\ \text { PCR } & 3,81(33) & 3,96(5) & 0,760 \\ \text { Harddat } & 4,32(27) & 4,33(12) & 0,962\end{array}$

Gemiddelde antwoorden m.b.t. effecten op het ontmoedigen van opportunisme

$\begin{array}{llll}\text { Elementen } & \begin{array}{l}\text { Gemiddeld } \\ \text { antwoord } \\ \text { ervaring } \\ \text { minder }\end{array} & \begin{array}{l}\text { Gemiddeld } \\ \text { antwoord } \\ \text { ervaring } \\ \text { meer }\end{array} & \begin{array}{l}\text { Significantie } \\ (\mathrm{p} \leq 0,05)\end{array} \\ \text { Funcspec } & 3,80(12) & 3,45(19) & 0,276 \\ \text { Budgetinf } & 3,62(27) & 3,42(3) & 0,778 \\ \text { PPI } & 3,74(21) & 3,97(6) & 0,581 \\ \text { RAVA } & 3,97(16) & 3,88(13) & 0,811 \\ \text { Qsleutelf } & 3,98(25) & 4,38(2) & 0,498 \\ \text { Pr/kwal } & 3,95(11) & 3,84(19) & 0,733 \\ \text { Risktrans } & 4,10(13) & 4,10(15) & 0,989 \\ \text { PCR } & 4,18(25) & 3,88(4) & 0,491 \\ \text { Harddat } & 3,83(22) & 3,43(7) & 0,320\end{array}$

Tabel 6.8; Verschillen in antwoorden tussen minder/meer ervaring PiPSOG

Zoals uit bovenstaande tabel blijkt zijn de verschillen bij de antwoorden die betrekking hebben op het ontmoedigen van de neiging tot opportunistisch gedrag nergens significant. Bij de antwoorden die betrekking hebben op het reduceren van onzekerheid is alleen sprake van significantie bij functioneel specificeren en bij het overdragen van risico's. De aantallen antwoorden (n) is bij een aantal cellen dermate gering 
dat de uitkomsten met terughoudendheid geïnterpreteerd dienen te worden. Een duidelijke samenhang tussen de mate van ervaring met pips elementen en de mate waarin respondenten de NIE effecten (reduceren van onzekerheid en ontmoedigen van de neiging tot opportunistisch gedrag) verwachten is op grond van deze statistische toetsen niet aan te tonen.

PiPSON: Verschillen tussen antwoorden van categorieën minder \& meer ervaring

Gemiddelde antwoorden m.b.t. effecten op het reduceren van onzekerheid

$\begin{array}{llll}\text { Elementen } & \begin{array}{l}\text { Gemiddeld } \\ \text { antwoord } \\ \text { ervaring } \\ \text { minder }\end{array} & \begin{array}{l}\text { Gemiddeld } \\ \text { antwoord } \\ \text { ervaring } \\ \text { meer }\end{array} & \begin{array}{l}\text { Significan } \\ (\mathrm{p} \leq 0,05)\end{array} \\ \text { Funcspec } & 4,14(27) & 4,15(19) & 0,959 \\ \text { Budgetinf } & 3,60(42) & 3,25(5) & 0,474 \\ \text { PPI } & 4,03(21) & 3,82(26) & 0,522 \\ \text { RAVA } & 4,44(23) & 4,36(24) & 0,751 \\ \text { Qsleutelf } & 3,58(33) & 3,47(14) & 0,746 \\ \text { Pr/kwal } & 4,77(20) & 4,66(27) & 0,559 \\ \text { Risktrans } & 4,21(24) & 3,99(23) & 0,260\end{array}$

Gemiddelde antwoorden m.b.t. effecten op het ontmoedigen van opportunisme

$\begin{array}{llll}\text { Elementen } & \begin{array}{l}\text { Gemiddeld } \\ \text { antwoord } \\ \text { ervaring } \\ \text { minder }\end{array} & \begin{array}{l}\text { Gemiddeld } \\ \text { antwoord } \\ \text { ervaring } \\ \text { meer }\end{array} & \begin{array}{l}\text { Significantie } \\ (\mathrm{p} \leq 0,05)\end{array} \\ \text { Funcspec } & 3,17(27) & 2,97(18) & 0,297 \\ \text { Budgetinf } & 2,87(41) & 3,10(5) & 0,485 \\ \text { PPI } & 3,62(21) & 2,98(25) & 0,027 \\ \text { Qsleutelf } & 3,60(33) & 3,45(14) & 0,633 \\ \text { Pr/kwal } & 3,25(20) & 3,42(26) & 0,602 \\ \text { Risktrans } & 3,15(24) & 3,32(22) & 0,469\end{array}$

Tabel 6.9; Verschillen in antwoorden tussen minder/meer ervaring PiPSON

Uit tabel 6.9 blijkt dat de verschillen tussen de antwoorden die betrek-

king hebben op onzekerheid nergens significant. Bij de antwoorden die betrekking hebben op opportunisme is enkel één significant verschil gevonden bij past performance information. Ook deze tabel moet met enige terughoudendheid worden geïnterprteerd vanwege de geringe aantallen antwoorden.

De overall bevindingen naar aanleiding van deze verschillen analyse is dan ook dat in dit onderzoek geen duidelijke samenhang is gevonden tussen de mate van ervaring en de antwoordpatronen. Op grond van deze uitkomst zijn de onderzoeksresultaten (alhoewel gebaseerd op een a select gekozen groep respondenten) beter te generaliseren naar een grotere populatie vergeleken met de situatie dat de verschillen tussen weing en veel ervaring groot zouden zijn. 


\section{Analyse en interpretatie}

PiPsog; reduceren van onzekerheid

De PiPsog respondenten onderschrijven dat toepassen van pips safeguards onzekerheid voor hen reduceert. De gemiddelde score van alle 8 de matrixvragen op dit gebied bedraagt 4,07 (25\% respectievelijk $75 \%$ tussen 3,62 en 4,56; zie tabel 8.11) op een schaal van een tot zes (waarbij "een" staat voor helemaal oneens en "zes" voor helemaal eens). Bij vier van de acht vragen ligt de modus zelfs op vijf, bij de andere helft op vier. De boxplots (afbeelding 6.3) geven helder weer dat de medianen van alle safeguards vier of hoger scoren, behalve het functionele specificeren (Funcspec). Het hanteren van een specificatie die een redelijke mate van oplossingvrijheid bevat, zal in de ogen van opdrachtgevers niet krachtig bijdragen tot het reduceren van onzekerheid. Een mogelijke verklaring hiervoor is gelegen in het feit dat het hanteren van een dergelijke specificatie met zich meebrengt dat je als opdrachtgever moet durven 'loslaten'. Dat vormt een wezenlijke verandering ten opzichte van de meest voorkomende (traditionele) werkwijze waarbij men juist gewend is 'zoveel mogelijk' in technische specificaties vast te leggen. Beschikken over harde performance data (Harddat) en het meewegen van de kwaliteit van sleutelfunctionarissen scoren bovengemiddeld. Opvallend is dat men van deze safeguards dus veel verwacht, maar ze worden nog niet veel toegepast (zie tabel 8.5). De interne homogeniteit van deze set vragen scoort met een Cronbach's $\alpha$ van 0,834 goed (laagste $\alpha$ is 0,650 en hoogste 0,950 )

Bovenstaande leidt tot de volgende interpretatie: PiPsog respondenten verwachten dat toepassen van pips elementen in redelijke mate onzekerheid voor hen reduceert. Deze gereduceerde onzekerheid manifesteert zich voor opdrachtgevers als volgt (weergegeven in afnemende volgorde van door respondenten gescoord effect):

- Meer vertrouwen in de gecontracteerde aannemer $(4,32)$

- Over meer relevante informatie beschikken aan de hand waarvan het verloop van het project voorspeld kan worden $(4,31)$

- Minder onzekerheid over de coöperatieve houding van de aannemer aan wie gegund is $(4,23)$

- Minder zorgen over onvoorziene gebeurtenissen $(4,02)$
- Minder onzeker ten aanzien van de contractuele vastlegging van hetgeen is overeengekomen $(3,97)$

- Minder onzekerheid over de wijze waarop de opdrachtgever de vraag heeft geformuleerd $(3,82)$

PiPsoG; ontmoedigen van opportunisme

Voor de pipsog vragen met betrekking tot het ontmoedigen van opportunisme geldt in grote lijnen hetzelfde, zij het dat de antwoorden iet meer 'naar het midden neigen'; de medianen liggen allen zoals de boxplots in afbeelding 6.4 laten zien tussen de drie en vier. De modus wordt gevormd door vier. De interne homogeniteit van deze set vragen scoort met een Cronbach's a van 0,931 hoog (laagste $\alpha$ is 0,794 , hoogste $\alpha$ is o,962).

Bovenstaande leidt tot de volgende interpretatie: Pipsog respondenten verwachten dat toepassing van pips elementen in redelijke mate de neiging tot opportunistisch gedrag van opdrachtnemers ontmoedigt. Dit ontmoedigde opportunisme van opdrachtnemers manifesteert zich voor opdrachtgevers als volgt (weergegeven in afnemende volgorde van door respondenten gescoord effect):

- Meer eigen initiatief van de gecontracteerde aannemer $(4,05)$

- Grotere bereidheid van de aannemer om gemaakte fouten te herstellen $(3,94)$

- Inzet van beter geschoold personeel $(3,93)$

- Coöperatiever gedrag van de gecontracteerde aannemer $(3,91)$

- Meer open en oprechte houding van de gecontracteerde aannemer $(3,85)$

- Het in mindere mate voorkomen van 'claimgedrag' $(3,76)$

- Minder last van 'laag inschrijven' en na gunning proberen voordelen binnen te halen $(3,73)$

- Aannemer zal in mindere mate geneigd zijn onvolkomenheden in het bestek uit te buiten $(3,53)$

\section{PiPSoN; reduceren van onzekerheid}

De Pipson respondenten onderschrijven dat het toepassen van pips elementen onzekerheid voor hen reduceert. De gemiddelde score voor alle zeven vragen op dit gebied bedraagt 4,17 (25\% respectievelijk $75 \%$ tussen 3,63 en 4,57; zie tabel 6.7) op een schaal van één tot zes (waarbij 
“een" staat voor helemaal oneens en "zes" voor helemaal eens). De mediaan van alle vragen schommelt ook rond de vier (zie afbeedling 6.5). De modus wordt gevormd door vijf. Het hanteren van prijs én kwaliteit als criterium vormt hierop een positieve uitzondering; de mediaan ligt op 4,60. Datzelfde geldt voor het risk assessment plan waarvan de mediaan op 4,43 ligt. De interne homogeniteit voldoet met een Cronbach's a van 0,757 aan de vereisten (laagste a is 0,589 en de hoogste $\alpha$ is 0,949$)$. Wel hebben twee items een lagere score dan de veelal als ondergens geldende 0,7 . Eliminatie van deze twee items weegt qua dataverlies echter niet op tegen het verhogen van de homogeniteit. Bovenstaande leidt tot de volgende interpretatie. Respondenten van Pipson verwachten dat toepassen van pips elementen onzekerheid voor hen reduceert. Gereduceerde onzekerheid manifesteert zich voor opdrachtnemers als volgt (weergegeven in afnemende volgorde van door respondenten gescoord effect):

- Meer mogelijkheden zien om een gezond rendement te kunnen realiseren $(4,24)$

- Meer vertrouwen in het functioneren van de projectorganisatie $(4,21)$

- Beter in kunnen spelen op onvoorziene gebeurtenissen $(4,16)$

- Meer vertrouwen in goede afloop van een werk $(4,16)$

- Minder onzekerheid met betrekking de voor het werk benodigde kennis $(4,10)$

- Meer inzicht in kansen bij aanbestedingen $(4,10)$

- Minder onzekerheid met betrekking tot het juist inschatten van werk $(3,83)$

\section{PipsoN; ontmoedigen van opportunisme}

De pipson respondenten zijn sceptisch als het gaat om de mate waarin het toepassen van pips elementen opportunistisch gedrag aan opdrachtgeverszijde ontmoedigt. De gemiddelde score voor de zes vragen uit deze set scoort 3,08 (25\% respectievelijk 75\% tussen 2,86 en 3,42; zie afbeelding 6.6) op een schaal van één tot zes (waarbij "een" staat voor helemaal oneens en "zes" voor helemaal eens). De mediaan ligt voor alle safeguards op drie (zie afbeedling 6.6). De boxplots laten duidelijk zien dat de antwoorden overwegend rechts van de mediaan liggen (alleen bij de safeguard Budginf ligt de mediaan centraal ten opzichte van het
$25 \%$ en $75 \%$ kwartiel); het merendeel van de respondenten is neutraal over de effecten die het toepassen van pips elementen heeft op het ontmoedigen van de neiging tot opportunistisch gedrag bij opdrachtgevers.

Omdat bij deze vragenset maar telkens twee of drie operationalisatie van opportunistisch gedrag zijn opgenomen, is het niet mogelijk een Cronbach's a per vraag te berekenen. De Cronbach's a voor de gehele set komt uit op o,840. Daarmee is deze vragenset voldoende homogeen, en wordt voldaan aan de vereisten om van een valide meting te kunnen spreken.

pipson respondenten zijn sceptisch als het gaat om de effecten die het toepassen van pips safeguards hebben op het ontmoedigen van opportunistisch gedrag aan de zijde van opdrachtgevers. De meest waarschijnlijke verklaring is dat opdrachtnemers verwachten dat opdrachtgevers toch "voor een dubbeltje op de eerste rang willen zitten". Aanvullend onderzoek op dit gebied is echter nodig. Bovenstaande leidt tot de volgende interpretatie. Pipson respondenten verwachten niet da toepassen van pips elementen opportunistisch gedrag bij opdrachtgevers zal ontmoedigen.

\section{Terugkoppeling naar de vier centrale vragen:}

De op de volgende pagina afgebeelde tabel laat zien in welke mate volgens respondenten de op basis van het theoretisch model verwachte effecten op zullen treden. De weergegeven cijfers zijn de gemiddelde waarden van ONZgem en OPPgem (zie tabellen 6.6 en 6.7 uit pipso en pipson). Het effect op het reduceren van onzekerheid is bij opdrachtgevers en opdrachtnemers nagenoeg gelijk (het verschil is niet significant). Het effect op het ontmoedigen van opportunisme is volgen opdrachtgevers beduidend hoger dan volgens opdrachtnemers. 


\begin{tabular}{|c|c|c|}
\hline & PiPsog & PiPsoN \\
\hline $\begin{array}{l}\text { Effect op } \\
\text { onzeker- } \\
\text { heid }\end{array}$ & $\begin{array}{l}\text { Vraag 1: 4,07 } \\
\text { van max 6,oo } \\
\text { (68\%) } \\
\text { Modus: } \\
\text { grotendeels } \\
\text { mee eens }\end{array}$ & $\begin{array}{l}\text { Vraag 2: } 4,10 \\
\text { van max 6,oo } \\
\text { (68\%) } \\
\text { Modus: } \\
\text { grotendeels } \\
\text { mee eens }\end{array}$ \\
\hline $\begin{array}{l}\text { Effect op } \\
\text { opportu- } \\
\text { nisme }\end{array}$ & $\begin{array}{l}\text { Vraag 3: } 3,81 \\
\text { van max 6,oo } \\
\text { (64\%) } \\
\text { Modus: } \\
\text { enigzins mee } \\
\text { eens }\end{array}$ & $\begin{array}{l}\text { Vraag 4: 3,17 } \\
\text { van max 6,oo } \\
(53 \%) \\
\text { Modus: } \\
\text { enigzins mee } \\
\text { oneens }\end{array}$ \\
\hline
\end{tabular}

Tabel 6.10; Gemiddelde waarden van effecten van PiPs safeguards volgens respondenten van PiPSOG en PiPSON

\section{Reflectie en verantwoording:}

De resultaten van dit kwantitatief onderzoek bevestigen voor drie van de vier centrale vragen wat voorondersteld werd op basis van de usa ervaringen, het theoretisch model en de bij de praktijkcases opgedane ervaringen. De vraag is nu in hoeverre generaliseerbaarheid van dit onderzoek naar 'de bouw' in het algemeen mogelijk is. Er is immer geen a-selecte steekproef genomen, maar er is bewust gezocht naar respondenten die bij organisaties werken die meer dan gemiddeld vernieuwend bezig zijn met aanbesteden (daarmee is de generaliseerbaarheid per definitie beperkt). Ook is de Gww sector dominant vertegenwoordigd vergeleken bij de andere sectoren. Uit analyse van de onderzoeksgegevens blijkt echter dat respondenten die relatief weing ervaring hebben met innovatieve elementen niet wezenlijk anders scoren dan respondenten die aangegeven hebben over relatief veel ervaring te beschikken. Dit vormt aanleiding te vooronderstellen dat de resultaten van dit onderzoek minstens indicatief kunnnen zijn voor andere en/of grotere populaties binnen sectoren die nog overwegend traditioneel aanbesteden.

Als belangrijkste methodologische kwetsbaarheid van dit kwantitatief onderzoek zie ik de wijze waarop de stellingen zijn gevormd. De confrontaties tussen de safeguards en de operationalisaties van onzekerheid respectievelijk opportunisme zijn gebaseerd op vooronderstellingen. Deze vooronderstellingen zijn in 2008/2009 overwegend impliciet gevormd en toegepast. Inmiddels is het inzicht op dit gebied verder ontwikkeld dankzij de verwerking van de feedback van de leden van de promotiecommissie, kritische vragen van de promotor, dankzij het structureel participeren bij de type a meetings en ook dankzij de ervaringen die vanaf 2010 in de praktijk zijn opgedaan met PIPS aanbestedingen (zie ook tabel in Bijlage $\mathrm{x}$ ) voor woningstichtingen (Land van Rode; drie aanbestedingen, en Berg en Terblijt; één aanbesteding) en een zorgorganisatie (Circero Zorggroep; twee afgeronde aanbestedingen en één lopende aanbesteding). Het ligt voor de hand da wanneer het kwantitatief onderzoek met de huidige inzichten opnieuw vormgegeven zou zijn, de confrontaties andere stellingen opgeleverd zouden hebben. Dit zou van invloed geweest kunnen zijn op de onderzoeksresultaten.

Daar staat tegenover dat bij alle door mij begeleide aanbestedingen de werking van het theoretisch model optreedt en evaluaties opleveren dat opdrachtgevers en opdrachtnemers verklaren dat hun ervaringen met pips in lijn liggen met de uitkomsten van het kwantitatief onderzoek en de verwachtingen op grond van het theoritische model. Dat brengt mij tot de conclusie dat de methodologische kwetsbaarheid zoals hiervoor beschreven zeker aan de orde is, maar dat onderzoeksresultaten desondanks houvast bieden.

\subsection{Deelconclusies Kwantitatief Onderzoek}

Met dit kwantitatieve onderzoek werd getoetst of 'de praktijk' verwacht dat toepassing van pips elementen zal leiden tot de effecten zoals verwacht op basis van het ontwikkelde model. Dat model geeft aan dat toepassing van pips elementen onzekerheid reduceert en de neiging tot 
het vertonen van opportunistisch gedrag ontmoedigt. Respondenten zijn het daar grotendeels doch niet geheel mee eens. Op basis van verwerking, interpretatie en analyse van de verzamelde gegevens volgen onderstaand de deelconclusies.

\section{Deelconclusie 6.}

RESPONDENTEN MET VEEL ERVARING DENKEN NIET WEZENLIJK ANDERS OVER DE EFFECTEN VAN DE PIPS SAFEGUARDS DAN RESPONDENTEN MET WEING ERVARING.

Zie tabellen 6.8 en 6.9

\section{Deelconclusie $\mathbf{6 . 2}$}

OPDRACHTGEVERS VERWACHTEN DAT HET TOEPASSEN VAN PIPS ELEMENTEN IN REDELIJKE MATE ONZEKERHEID VOOR HEN REDUCEERT.

Zie tabellen 6.6 en afbeelding 6.3

\section{Deelconclusie 6.3}

OPDRACHTGEVERS VERWACHTEN DAT TOEPASSEN VAN PIPS ELEMENTEN IN REDELIJKE MATE DE NEIGING TOT HET VERTONEN VAN OPPORTUNISTISCH GEDRAG NA GUNNING DOOR OPDRACHTNEMERS ZAL ONTMOEDIGEN.

Zie tabel 6.6 en afbeelding 6.4

\section{Deelconclusie 6.4}

OPDRACHTNEMERS VERWACHTEN DAT HET TOEPASSEN VAN PIPS ELEMENTEN IN REDELIJKE MATE ONZEKERHEID VOOR HEN REDUCEERT.

Zie tabel 6.7 en afbeelding 6.5
Deelconclusie $\mathbf{6 . 5}$

OPDRACHTNEMERS ANTWOORDEN NAGENOEG NEUTRAAL

VOOR WAT BETREFT DE MATE WAARIN HET TOEPASSEN VAN

PIPS SAFEGUARDS OPPORTUNISTISCH GEDRAG VAN

OPDRACHTGEVERS ONTMOEDIGT

Zie tabel 6.7 en afbeelding 6.6 


\section{conclusies en}

\section{aanbevelingen}

7.0 Inleiding

Achtereenvolgens is verkend hoe pips in elkaar zit, wat de effecten van de methodiek zijn en hoe de werking verklaard kan worden en ook de (juridische) toepassingsmogelijkheden van de pips elementen zijn onderzocht. Ook is de methodiek toegepast in praktijkcases en is ter validering in beeld gebracht of 'de praktijk' de redeneerlijnen van het theoretisch model volgt.

In dit hoofdstuk worden de conclusies weergegeven die naar aanleiding van dit onderzoek zijn te trekken. De structuur waarin de conclusies worden weergegeven, wordt hieronder toegelicht. Aan deze conlusies worden vervolgens aanbevelingen gekoppeld. Deze aanbevelingen zijn gesegmenteerd naar beleidsmakers, onderwijs, opdrachtgevers, opdrachtnemers en wetenschap. De conclusies en aanbevelingen zijn gebaseerd op de tijdens dit onderzoek opgedane inzichten waarbij de theoretische en praktische invalshoek beiden een waardevolle bijdrage hebben geleverd.

De weergave van de conclusies volgt in hoofdlijnen de structuur van dit onderzoek. Eerst volgen conclusies ten aanzien van de werking van pips, waarna de juridische inpasbaarheid aan de orde komt. Waar gesproken wordt over pips en/of Best Value Procurement kan ook gelezen worden het toepassen van enkele van de pips elementen, en vice versa, tenzij dit uitdrukkelijk anders staat vermeld. 
hoogte van het beschikbare budget, past performance information, risk assessment/value added, kwaliteit van sleutelfunctionarissen en gunnen op waarde als tegenhanger van het hanteren van de laagste prijsklem.

${ }^{90}$ Waardoor het realiseren van een faire marge binnen bereik komt. basis van een slimme oplossing, een geschikte projectleider, een van visie getuigend en wel doordacht risk assessment plan. Dat zijn allemaal zaken waar ze zelf invloed op kunnen uitoefenen, daardoor hebben ze meer vertrouwen in de goede afloop van een project.

pips safeguards blijken inderdaad, zoals verwacht op grond van het theoretisch model, bij te dragen aan het reduceren van onzekerheid, het ontmoedigen van de neiging tot het vertonen van opportunistisch gedrag en maken het makkelijker om te gaan met begrensde rationaliteit van actoren. Het op NIE gebaseerde theoretisch model voorspelt deze effecten; de praktijkcases wijzen in die richting en het kwantitatief onderzoek komt voor drie van de vier centrale vragen tot dezelfde inzichten.

Toepassing van pips safeguards reduceert onzekerheid voor de opdrachtgever (hoofdstuk twee, vijf en zes). De pips aanpak zorgt ervoor dat er meer en ook meer relevante informatie beschikbaar is op basis waarvan keuzes gemaakt worden. Dit wordt in de praktijk (en ook conform de verwachtingen op basis van het theoretisch model) met name veroorzaakt door de safeguards Budgetinf, PPI, RAVA, Qsleutelf en Pr/kwal ${ }^{89}$. Door informatie ten aanzien van het maximaal aan te wenden budget op voorhand met marktpartijen te delen (en er de consequentie van 'terzijde legging' bij overschrijding daarvan aan te verbinden) wordt het risico van ongeldige inschrijvingen verkleind. Het risico van het kiezen van een incompetente marktpartij is kleiner doordat past performance information meeweegt en ook de mate waarin een marktpartij in staat is risico's te duiden, ze te prioriteren en van adequate remedies te voorzien van invloed is op de uiteindelijke keuze. Onzekerheid ten aanzien van de vraagspecificatie wordt gereduceerd doordat de verantwoordelijkheid voor een 'werkende oplossing' ligt bij de marktpartij die deze oplossing inbrengt en alleen inbreng van partijen met bewezen high performance uiteindelijk toegelaten worden. Onzekerheid ten aanzien van het naleven van het overeengekomene wordt gereduceerd doordat de 'laagste-prijs-klem' wordt gemeden, er tijdens de uitvoering harde performance data beschikbaar is en het 'reputatiemechanisme' haar werk kan doen.

Voor opdrachtnemers wordt onzekerheid gereduceerd (hoofdstuk een, twee, drie, vijf en zes) omdat ze het project meer naar hun hand kunnen zetten, ze zich kunnen onderscheiden op kwalitatieve criteria en niet alleen op laagste prijs ${ }^{\circ}$. Ze kunnen dus een aanbesteding winnen op conclusie

DE EMPIRIE (PRAKTIKCASES EN KWANTITATIEF ONDERZOEK) BEVESTIGT HETGEEN HET OP NIE GEBASEERDE THEORETISCH MODEL VOORSPELT VOOR WAT BETREFT HET REDUCEREN VAN ONZEKERHEID EN HET ONTMOEDIGEN VAN DE NEIGING TOT HET VERTONEN VAN OPPORTUNISTISCH NA GEDRAG GUNNING DOOR OPDRACHTNEMERS.

Conclusie 1.1 is gebaseerd op het theoretisch onderzoek, de praktijkcases en het kwantitatief onderzoek.

pips wise aanbestede projecten leiden tot duidelijk betere projectresultaten dan doorgaans traditioneel worden bereikt (hoofdstuk een, twee, vijf en zes) omdat pips de 'laagste-prijs-klem' mijdt, aannemers vroeger betrekt en in de gelegenheid stelt waarde toe te voegen, (meer) aandacht besteedt aan risicomanagement, het reputatiemechanisme (past performance information) haar werk laat doen, aandacht besteedt aan de kwaliteit van sleutelfunctionarissen, zich beperkt tot 'dominante en onderscheidend vermogen biedende' informatie, tijdens de uitvoering risico's legt bij de partij die ze het beste kan managen en stuurt aan de hand van harde performance data. Dit alles leidt tot meer projecten die opgeleverd worden binnen planning en budget en naar tevredenheid van de opdrachtgever. Ook aan de opdrachtnemerskant zijn er indicaties dat de pips aanpak tot meer waardering leidt (vergeleken bij de traditionele aanpak). Hiernaar is echter meer onderzoek nodig.

Daarnaast leidt het vroeger betrekken van marktpartijen tot meer integratie en wordt innovatie bevorderd, deze zaken maken deel uit van het wenkend perspectief dat de bouwsector nastreeft. Het bevorderen 
van samenwerking maakt eveneens deel uit van dit wenkend perspectief; ook hieraan draagt pips bij.

\section{conclusie $\mathbf{1 . 2}$}

HET TOEPASSEN VAN PIPS SAFEGUARDS REDUCEERT ONZEKER HEID VOOR OPDRACHTGEVER EN OPDRACHTNEMER, ZOWEL EX ANTE ALS EX POST CONTRACT

Conclusie 1.2 is gebaseerd op literatuuronderzoek, het op NIE gebaseerde theoretische model en wordt bevestigd door de praktijkcases. Ook het kwantitatief onderzoek indiceert dat onzekerheid voor opdrachtgever en opdrachtnemer door toepassing van pips safeguards wordt gereduceerd.

Het toepassen van pips safeguards reduceert de neiging tot opportunistisch gedrag van opdrachtnemers (hoofdstuk drie, vijf en zes) doordat er sprake is van gunnen op waarde (in plaats van gunnen op laagste prijs bij de traditionele aanpak). Ze kunnen het zich daardoor permitteren om vakmensen, deugdelijke materialen etc. in te zetten. Marchanderen daarmee is simpelweg niet nodig in dit concept. Hier staat tegenover dat in situaties waarin de kosten de opbrengsten dreigen te overschrijden (reëel risico bij het hanteren van de 'laagste-prijs-klem'), het waarschijnlijk is dat de opdrachtnemer zich opportunistisch zal

${ }^{91}$ Kadefors, 2005: “ Een aanbesteding zou moeten leiden tot een faire prijs, dat voorkomt opportunistisch gedrag" gedragen ${ }^{91}$. Ook het vroeger betrekken van opd rachtnemers en ze ruimte bieden om eigen inbreng te hebben reduceert de neiging tot opportunistisch gedrag doordat er sprake is van een groter commitment met het project en ook naar de opdrachtgever toe. Als derde element in dit kader speelt het 'reputatiemechanisme' een belangrijke rol. Opdrachtnemers weten dat de op dit werk feitelijk gerealiseerde performance goede of minder goede PPI scores op zal leveren die ingezet kunnen worden bij toekomstige aanbestedingen en daarmee van invloed zijn op de kansen op toekomstig werk. Opportunistisch gedrag draagt daar niet aan bij. De safeguards die in de praktijk (en ook conform de verwachtingen op basis van het theoretisch model) het meeste bijdragen aan het ontmoedigd opportunisme: Pr/kwal, Funcspec, PPI, Qsleutelf Opportunistisch gedrag aan opdrachtgeverszijde wordt in de ogen van opdrachtnemers slechts in beperkte mate ontmoedigd door het toepassen van pips (hoofdstuk zes). Een mogelijke verklaring hiervoor (die nader onderzoek vraagt; zie verderop) is gelegen in het feit dat opdrachtgevers decennia lang de werkwijze gehanteerd hebben 'alles' voor te schrijven en vervolgens te zoeken naar de partij die het gevraagde tegen de laagste prijs kan realiseren. De veronderstelling luidt dat opdrachtnemers sceptisch zijn ten opzichte van een gedragsverandering hieromtrent bij opdrachtgevers ("willen als het erop aan komt toch voor een dubbeltje op de eerste rang zitten”).

\section{conclusie $\mathbf{1 . 3}$}

TOEPASSING VAN PIPS SAFEGUARDS ONTMOEDIGT DE NEIGING TOT EN RUIMTE VOOR OPPORTUNISTISCH GEDRAG NA GUNNING BUJ OPDR ACHTNEMERS.

Conclusie 1.3 is eveneens gebaseerd op literatuuronderzoek, het theoretisch model, de praktijkcases en het kwantitatief onderzoek wijzen allen in deze zelfde richting. Opdrachtnemers zijn echter sceptisch als het gaat om de ontmoediging van de neiging tot het vertonen van opportunistisch gedrag door opdrachtgevers als gevolg van het toepassen van pips safeguards.

pips speelt in op begrensde rationaliteit van actoren (hoofdstuk twee, drie en vijf) doordat alleen informatie 'toegelaten wordt' die relevant, to the point en countable is. Daarmee wordt een overload aan informatie voorkomen en wordt informatie beter hanteerbaar. Dit uit zich in een compact, in omvang gelimiteerd RAP/RAVA, PPI volgens een format (omvang ook gelimiteerd), het toekennen van scores aan alle pips filters en het werken met harde performance data tijdens de uitvoeringsfase. Dit alles draagt bij aan het verhogen van efficiency, het zo min mogelijk
${ }_{92}$ Respectievelijk: gunnen op waarde (in plaats van alleen laagste prijs die tot onderscheidend

vermogen kan leiden), een oplossingsvrije vraag waardoor partijen vroeger betrokken worden en werk naar hun han kunnen zetten een appèl op het reputatiemechanisme (dat aannemers niet graag op het spel zetten) en aandacht voor de kwaliteit van sleutelfunctionarissen 
maken van keuzes (op basis van 'ervaring' en/of windowdressing informatie) maar het zoveel mogelijk 'laten spreken' van verzamelde en verwerkte informatie. Pips beïnvloedt dus niet begrensde rationaliteit an sich, maar wel de consequenties die deze onontkoombare conditie heeft wat zich manifesteert als geringere onzekerheid.

\section{conclusie $\mathbf{1 . 4}$}

TOEPASSING VAN PIPS SAFEGUARDS SPEELT IN OP BEGRENSDE RATIONALITEIT VAN ACTOREN.

Conclusie 1.4 is vooral gebaseerd op literatuuronderzoek en het theoretisch model. Tijdens de praktijkcases bleek wel dat de pips methodiek als helder en goed hanteerbaar werd ervaren, er is echter geen data verzameld ten aanzien van de mate waarin pips rekening houdt met de begrensde rationaliteit van actoren.

Conclusies die betreking hebben op de juridische inpasbaarheid van Pips:

Aanbestedingsplichtige diensten kunnen desgewenst alle pips elementen uit de contact- en contractfase toepassen. Een nuancering op dit punt betreft de interviews met de sleutelfunctionarissen. De meningen van deskundigen op dit punt zijn verdeeld. Daaraan zijn minstens voorwaarden verbonden waaraan overigens veel van de hedendaagse bouwopgaven voldoen (het belang van competenties van sleutelfunctionarissen voor projectsucces ten aanzien van proceskwaliteit, moet van meet af aan duidelijk uit alle aanbestedingsstukken blijken). Er zijn ook deskundigen die van mening zijn dat het interviewen van sleutelfunctiona- rissen in het kader van het aanbesteden van werken ongeoorloofd is. $\mathrm{Zij}$ kennen een smallere betekenis toe aan, aan de persoon verbonden vaardigheden, talenten en dergelijke. Voor het toepassen van gunnen op basis van prijs en kwaliteit gelt het hanteren van EMVI als gunningscriterium als voorwaarde. Voor het toepassen van het PPI element is in het kader van dit onderzoek een variant ontwikkeld die tegemoet komt aan bezwaren van objectiviteit en disproportionaliteit. Het toekennen van de PCR score aan het einde van het project zoals dat dee uit maakt van Kashiwagis's aanpak, is niet geoorloofd (zie voor dit alles hoofdstuk vier). Tevens is in het kader van dit onderzoek een procesontwerp gemaakt, getoetst en toegepast waaruit blijkt dat de pips elementen tegen een 'aanvaardbaar risico' kunnen worden gehanteerd.

\section{conclusie $\mathbf{2 . 1}$}

BINNEN HET NEDERLANDSE JURIDISCH KADER KUNNEN (OOK DOOR AANBESTEDINGSPLICHTIGE DIENSTEN) PIPS ELEMENTEN UIT DE CONTACT- EN CONTRACT FASE (DEELS ONDER VOORWAARDEN) WORDEN TOEGEPAST

Conclusie 2.1 is gebaseerd op literatuuronderzoek en logische redeneringen en wordt onderschreven door de uitkomsten van de interviewronde waarbij 12 in aanbestedingsrecht gespecialiseerde juristen zijn bevraagd.

Conclusies die betreking hebben op de effectiviteit van pips.

conclusie $\mathbf{3 . 1}$

PIPS RESULTATEN VORMEN EEN WENKEND PERSPECTIEF VOOR DE BOUWSECTOR, EN DRAGEN DAARMEE BIJ AAN DE VERBETER- 
DOELSTELLINGEN DIE DE NEDERLANDSE BOUWSECTOR ZICH

\section{HEEFT GESTELD.}

Conclusie 3.1 is gebaseerd op de USA resultaten, de NIE mechanismen, de indicaties uit de praktijkcases, het juridisch onderzoek en de uitkomsten van het kwantitatief onderzoek.

Projecten die weinig uitdaging bevatten (commodities; weinig complex, weinig vernieuwend) lenen zich in mindere mate voor een Best Value Procurement benadering (hoofdstuk een en vijf). Deze projecten bevatten minder 'onzekerheid' en de pips aanpak is juist gericht op het reduceren daarvan (het $1^{\mathrm{e}}$ NIE mechanisme). Daarnaast is bij projecten die weinig onzekerheid bevatten de neiging tot opportunistisch gedrag (het tweede NIE mechanisme) ook geringer (hoofdstuk drie) en zal opportunistisch gedrag dat zich toch voordoet minder schadelijk zijn. Ook moeten projecten een zekere minimale omvang hebben om een gepaste verhouding tussen directe kosten en transactiekosten te bereiken. Het EMVI criterium moet gehanteerd kunnen worden waarbij kwaliteit gerelateerde criteria substantieel meewegen ten opzichte van prijs gerelateerde criteria. Opdrachtgevers moeten in staat en bereid zijn hun vraag in redelijke mate oplossingsvrij te formuleren; aannemers 'ruimte' te geven om waarde toe te voegen. Tot slot moeten projecten op een zekere afstand te managen zijn opdat de gecontracteerde marktpartij ook daadwerkelijk verantwoordelijkheid kan dragen voor de te behalen resultaten.

\section{conclusie $\mathbf{3 . 2}$}

PROJECTEN DIE VOLDOENDE OMVANG HEBBEN, VOLDOENDE UITDAGING BIEDEN EN OP ENIGE AFSTAND ZIJN TE MANAGEN, ZIJN GESCHIKT VOOR EEN INNOVATIEVE AANPAK ALS PIPS. Conclusie 3.2 is gebaseerd op literatuuronderzoek en is vooral ook duidelijk geworden bij toepassing van de praktijkcases (zie onder andere de cross case analyse in hoofdstuk zes).
Overall conclusie met betrekking tot de verklaring voor de werking van PiPs:

PiPs elementen werken als safeguards waardoor onzekerheid voor opdrachtgever en opdrachtnemer wordt gereduceerd en de neiging tot het vertonen van opportunistisch gedrag na gunning wordt ontmoedigd. Deze NIE mechanismen blijken vanuit het theoretisch model bij te dragen aan projectsucces. De empirie onderschrijft dit theoretisch model in belangrijke mate.

\subsection{Aanbevelingen}

De hiervoor weergegeven conclusies impliceren een aantal richtinggevende aanbevelingen voor beleidsmakers, onderwijs, opdrachtgevers, opdrachtnemers en de wetenschap. In deze paragraaf worden deze aanbevelingen verder geëxpliciteerd. Aanbevelingen voor beleidsmakers hebben vooral betrekking op zaken die toepassing van innovatieve aanpakken kunnen bevorderen vanuit de gedachte dat dit bij zal dragen aan de gewenste veranderingen in de sector. Aanbevelingen voor onderwijs zijn gericht op het in curricula inbouwen van het nieuwe aanbestedingsparadigma. Aanbevelingen voor opdrachtgevers beogen handvatten te zijn die bij kunnen dragen aan concrete toepassingen. Aanbevelingen die betrekking hebben op opdrachtnemers zijn bedoeld om hen concrete hulp te bieden bij het spelen van dit 'nieuwe spel'. Vandaar dat deze aanbevelingen wat breder uitgewerkt zijn dan die voor de overige stakeholders. Aanbevelingen ten behoeve van de wetenschap hebben vooral betrekking op vervolgonderzoek.

\section{Aanbevelingen voor de wetenschap}

Dit onderzoek bevat indicaties voor het feit dat ook opdrachtnemers de pips werkwijze verkiezen boven de traditionele aanpak. Op dit gebied is meer onderzoek nodig. In welke mate preferen opdrachtnemers BVP boven de traditionele aanpak?

pips zal alleen substantieel kunnen bijdragen aan gewenste veranderingen in de sector als opdrachtgevers én opdrachtnemers deze aanpak in voldoende mate zien zitten.

Waarop is de scepsis bij opdrachtnemers ten aanzien van het ontmoedigen van de neiging tot het vertonen van opportunistisch gedrag van opdrachtgevers gebaseerd?

De veronderstelling luidt dat de terughoudendheid bij opdrachtnemers 
${ }^{93}$ Inmiddels is hier ook een ruim aantal voorbeelden van beschikbaar in

Nederland variërend van adviesdiensten schoonmaakonder houd, onderhoud aan rollend materieel etc. ten aanzien van het ontmoedigen van opportunistisch gedrag bij opdrachtgevers veroorzaakt wordt door scepsis op grond van de ervaringen van de afgelopen decennia. Klopt deze veronderstelling? Zo nee, wat zijn dan de achterliggende oorzaken en hoe daarmee om te gaan? Zo ja, hoe kan deze scepsis het beste worden weggenomen? Ook op dit punt is nader onderzoek nodig.

In welke mate reduceert pips de benodigde managementcapaciteit aan opdrachtgeverszijde, en waarvan is deze reductie vooral afhankelijk? Nader onderzoek naar de indicatie dat de reductie van benodigde managementcapaciteit aan opdrachtgeverszijde enkele tientallen procenten bedraagt is nodig. Kan deze indicatie door middel van onderzoek worden bevestigd? Wat zijn de belangrijkste variabelen in dit kader en kan met behulp van een model op voorhand een schatting gemaakt worden van de te verwachten besparing?

Kan BVP succesvol worden toegepast in andere sectoren?

Op grond van de werking van PiPS en de in dit onderzoek gegeven verklaringen daarvoor is de verwachting dat de Best Value Procurement aanpak in heel andere sectoren dan de Bouw ook positieve effecten zal bewerkstelligen ${ }^{93}$. De NIE mechanismen zullen naar verwachting namelijk optreden bij alle transacties waarbij sprake is van een opdrachtgever en een opdrachtnemer in economisch verkeer, die afhankelijk van elkaar zijn, waarbij het nakomen van gemaakte afspraken en waarmaken wat beloofd is van essentieel belang is en er sprake is van risico's en onzekerheden. Aan deze voorwaarden wordt bij de aanbesteding van een bouwwerk voldaan, maar ook bij de aanbesteding van bijvoorbeeld schoonmaakonderhoud. Kashiwagi past pips in de USA ook toe voor ICT, Catering, adviesdiensten etc. Naar zijn zeggen zijn de resultaten minstens zo goed als de toepassingen in de bouw. Nader onderzoek op dit gebied is nodig. Cross Case analyses van praktijkcases lijken hiervoor de meest aangewezen methodiek.

Wat is de invloed van veranderende wetgeving en relevante jurisprudentie op de toepasbaarheid van pips?

Verder onderzoek naar de 'houdbaarheid' van de pips toepassingen binnen het in Nederland geldende juridisch kader is nodig. De in hoofdstuk zes ontwikkelde en beschreven twee varianten lijken redelijk 'claimbestendig', maar toekomstige jurisprudentie op dit terrein (met name voor wat betreft de ruimte om sleutelfunctionarissen te interviewen in de gunningsfase) kan tot nieuwe inzichten leiden. Ook de opgewaardeerde rol voor de pre-award fase roept juridische vraag tekens op die verder onderzoek naar de rechtmatigheid verlangen.

Hoe kan toepassing van BVP worden bevorderd?

De Bouw zal in de gewenste richting veranderen door het frequent en in de breedte van de sector toepassen van de methodiek. Daarin ligt de legitimatie voor verder onderzoek naar de wijze waarop toepassing van pips bevorderd kan worden. pips levert dermate positieve resultaten op dat het zonde zou zijn als slechts incidenteel opdrachtgevers met lef de methode toepassen.

\section{Aanbeveling voor de wetenschap 1.}

Voer nader onderzoek uit naar de de vraag hoe positief de ervaringen van opdrachtnemers met Best Value Procurement zijn.

\section{Aanbeveling voor de wetenschap 2.}

Onderzoek waarop de scepsis bij opdrachtnemers ten aanzien van het ontmoedigen van opportunistisch gedrag bij opdrachtgevers is gebaseerd en hoe deze scepsis kan worden teruggedrongen.

\section{Aanbeveling voor de wetenschap 3}

Onderzoek in welke mate reductie van benodigde managementcapaciteit aan opdrachtgeverszijde aan de orde is bij toepassing van Best Value Procurement en welke variabelen daarbij een dominante rol spelen. Ontwikkel op grond van die inzichten een model dat het maken van een betrouwbare voorspelling op dit punt mogelijk maakt.

\section{Aanbeveling voor de wetenschap 4.}

Onderzoek of en hoe Best Value Procurement ook in andere sectoren dan het aanbesteden van werken in de Bouw succesvol kan worden toegepast.

Aanbeveling voor de wetenschap 5.

Onderzoek hoe de juridische toepasbaarheid zoals in dit onderzoek uitgewerkt zich verhoudt tot de nieuwe aanbestedingswet. Onderzoek 
${ }^{94}$ Onder Beleidsmakers wordt hier onder andere ver-

staan de wetgevende macht, de toezichthoudende organen, gremia waarin grote opdrachtgevers zijn vertegenwoordigd, gezaghebbende organen als bijvoorbeeld de Vereniging van Aanbestedingsrecht, CROw en Pianoo. Ook plat-

forms als "vernieuwing bouw" worden in dit onderzoek geschaard onder de opinion makers/ leaders.

${ }^{95}$ Bij daarvoor geschikte projecten (zie hoofdstukken twee, drie en vijf )

${ }^{96}$ In de nieuwe aan bestedingswet wordt "EMVi tenzij..." opgenomen; een belangrijke impuls in dit kader.

${ }^{97} 30$ verkeersknelpunten (totale omvang 800 miljoen euro) worden via een versnelde procedure aangepakt waarbij enkele pips elementen toegepast worden; zie $w w w$.rijkswaterstaat/ spoedaanpak.nl tevens welke lessen uit toekomstige jurisprudentie op dit gebied zijn te leren. Ga ook na hoe de opgewaardeerde rol voor de pre-award fase zich verhoudt tot het wettelijk kader.

\section{Aanbevelingen voor beleidsmakers ${ }^{94}$}

Omdat pips bijdraagt aan de binnen de sector gewenste veranderingen (conclusie 1.2), is de eerste aanbeveling gericht op het bevorderen van de toepassing van pips. Als eerste aanbeveling wordt dan ook genoemd 'het geven van het goede voorbeeld' (beleidsmakers, en/of daaronder ressorterende uitvoeringsorganen hebben zelf ook nogal eens de rol van opdrachtgever). Toepassing van Best Value Procurement biedt ${ }^{95}$ ten opzichte van de traditionele benadering zodanige voordelen, dat de aanbeveling luidt overheidsopdrachtgevers deze aanpak als 'regel' te laten hanteren en de traditionele aanpak alleen in uitzonderingssituaties toe te laten passen ${ }^{96}$. Wanneer beleidsmakers bevorderen en stimuleren dat overheidsopdrachtgevers zelf in toenemende mate innovatieve aanpakken toepassen, zal daarvan een vliegwiel effect uitgaan naar de sector en het vertrouwen bij andere opdrachtgevers en bij opdrachtnemers toenemen. Met het opvolgen van deze aanbeveling kan de verschuiving van 'traditioneel naar innovatief' die langs het pad der geleidelijkheid verloopt, een duw in de goede richting krijgen en versneld worden. De spoedaanpak van $\mathrm{RWs}^{97}$ is in dit kader een mooi voorbeeld.

\section{Aanbeveling voor beleidsmakers 1.}

Overheidsopdrachtgevers doen er goed aan BVP als 'standaard' te

hanteren en alleen beargumenteerd daarvan af te wijken.

\section{Aanbeveling voor beleidsmakers 2.}

Beleidsmakers dienen een brede promotiecampagne (richten op opdrachtgevers, opdrachtnemers, adviseurs en onderwijs) te initiëren om de toepassing van Best Value aanbesteden een impuls te geven.
Als tweede wordt hier genoemd het doorbreken van de algemene misvatting dat de (Europese) aanbestedingsregels toepassing van de in dit onderzoek behandelde innovatieve elementen in de weg zouden staan. Zoals uit conclusie 2.1 is gebleken laat het juridisch kader voldoende mogelijkheden open om innovatief aan te besteden. Een communicatie inspanning op dit punt is op zijn plaats. Daarbij moeten opdrachtgevers bereikt worden, zij bepalen hoe een project 'in de markt wordt gezet'. Maar ook opdrachtnemers moeten in dit kader worden bereikt om 'koudwatervrees' weg te nemen ten aanzien van innovatieve procedures.

Aanbeveling voor beleidsmakers 3 .

Beleidsmakers binnen de sector doen er goed aan uit te dragen dat de geldende regelgeving voldoende ruimte biedt om Best Value aanbestedingen te kunnen doen en dat opdrachtnemers met deze aanpak faire kansen maken.

Aanbevelingen voor het onderwijs

Alhoewel hier geen onderzoek naar is gedaan, is het beeld dat onderwijs curricula de BVP inzichten nog niet geïncorporeerd hebben, terwij nu wel duidelijk is dat, en hoe, deze inzichten bijdragen aan succesvolle aanbestedingen. De eerste aanbeveling voor onderwijs wordt dan ook gevormd door het pleidooi om de nieuwe inzichten ten aanzien van innovatieve aanpak in te vlechten in curricula van bachelor en masteropleidingen op het gebied van built environment. De nieuwe generatie projectleiders en ingenieurs zal met deze kennis en inzichten op zak een goede bijdrage kunnen leveren aan de beoogde veranderingen: een sector met meer focus op kwaliteit, professionaliteit en innovatie, minder faalkosten, betere samenwerking, minder versnippering, meer projecten binnen planning en budget en naar tevredenheid opgeleverd. Daarnaast is de verwachting dat de beschreven mechanismen niet alleen tot gewenste effecten zullen leiden binnen de bouwsector. Ook voor aanbestedingen in heel andere sectoren zijn positieve effecten te verwachten vergeleken met de low bid traditie. Ook voor bijvoorbeeld 
studenten vastgoedmanagement, (technische) bedrijfskunde, facility management en commerciële economie zijn deze inzichten betekenisvol en dus verdient het aanbeveling ook in deze curricula aandacht te besteden aan deze inzichten.

\section{Aanbeveling voor het onderwijs 1.}

Omdat de 'tijdelijke coalities' die rondom bouwprojecten worden gevormd anders zullen samenwerken (het nieuwe aanbestedingsparadigma) hetgeen ook andere competenties van belanghebbenden vraagt, doen we hier de aanbeveling te bevorderen dat de nieuwe Best Value inzichten in de onderwijscurricula van vмво tot en met wo worden opgenomen

\section{Aanbeveling voor het onderwijs 2}

Het incorporeren van Best Value inzichten initiëren in opleidingscurricula binnen alle sectoren waarbij het make, buy or ally vraagstuk aan de orde is.

\section{Aanbevelingen voor opdrachtgevers}

${ }^{98}$ Door focus op kwaliteit (bijvoorbeeld $70 \%$ ten opzichte van prijs; $30 \%$ ) wordt het de aannemer mogelijk gemaakt een goede oplossing in te dienen voor een faire prijs (in tegenstelling tot gunnen op laagste prijs). Vermijd dus de 'laagste-prijsklem'. Daardoor is ook de neiging ('noodzaak') tot opportunistisch gedrag veel minder aanwezig.

\section{Ten aanzien van het toepasbaarheid van Best Value Procurement:} Bekijk als eerste of een bepaald project zich leent voor een innovatieve aanpak à la pips. Biedt het project voldoende uitdaging (complexiteit, nieuwe elementen) of is er eerder sprake van 'meer van hetzelfde'; gering vergeleken bij uitdagende projecten. Heeft het project een omvang die rechtvaardigt dat deze nieuwe aanpak (die in het begin vanwege leereffecten meer tijd kost) wordt toegepast? Leent het project zich ervoor een oplossingsvrije vraag te formuleren en in de markt te zetten? Kunnen we gunnen op waarde ${ }^{98}$ ? Met andere woorden: kan onderscheidend vermogen op kwalitatief gebied 'gewicht in de schaal leggen'? Is het project geschikt om de uitvoering over te dragen aan de partij die we contracteren en kunnen we dan zelf vanaf een zekere distantie commodities. Het onderscheidend vermogen bij deze commodities is managen (draag risico's die de aannemer beter kan dragen ook daadwerkelijk aan hem over. Dan wordt het ook zijn belang die risico's te managen)? Is het mogelijk een zekere life cycle costs benadering in de vraagstelling op te nemen (want juist als opdrachtnemers zich tijdens de exploitatie van een werk geconfronteerd weten met gemaakte keuze ten aanzien van onderhoud, beheer, energiegebruik etc. draagt dat bij tot het maken van duurzame en bedrijfseconomisch aantrekkelijke keuzes op dit vlak)? Hoe meer van deze vragen positief beantwoord kunnen worden, des te geschikter is een project voor een aanpak à la pips. Check ook of er voldoende draagvlak is in de organisatie voor de innovatieve aanpak die je voor ogen staat. Zonder dit draagvlak zullen 'behoudende krachten' aanleidingen vinden en benutten om het traject terug te buigen in de richting van de'gebaande paden'.

\section{Aanbeveling voor opdrachtgevers 1.}

Maak per project een bewuste keuze voor de aanpak: wat zal bij dit project het beste werken, een traditionele aanpak of de Best Value Procurement aanpak?

\section{Aanbeveling voor opdrachtgevers 2.}

Indien een project voldoende uitdaging bevat, op zekere afstand is te managen en de omvang het toelaat, pas dan als regel Best Value Procurement toe.

Ten aanzien van het toepassen van Best Value Procurement: Besteed voldoende aandacht aan instructie en training voor medewerkers die in deze aanbesteding een rol van betekenis spelen. Het is belangrijk dat ze de ratio achter de aanpak begrijpen en doorzien. Ook de informatiesessies ten behoeve van geïnteresseerde marktpartijen, gegadigden en inschrijvers, zijn van belang voor het welslagen van de aanbesteding. Deze marktpartijen moeten namelijk een goed besef hebben van wat er op hen afkomt, wat er gevraagd wordt en waarom 
dat gevraagd wordt. Alleen dan zijn ze in staat oplossingen en bijbehorende informatie aan te dragen die 'naadloos' aansluiten op de door de opdrachtgever gestelde vraag. Onderschat bij dat alles het 'ontleren' niet; medewerkers die gewend zijn technisch te specificeren en nu over moeten schakelen op het formuleren van een oplossingsvrij geformuleerde vraagstelling, staan voor een behoorlijke uitdaging. Ook zijn ineens andere competenties nodig om oplossingen met elkaar te kunnen vergelijken en af te zetten tegen de gestelde vraag. In de 'oude situatie' kon bij wijze van spreken volstaan worden met het vergelijken van de prijsstellingen (de inhoud kwam immers overeen; want was conform bestek). In de 'nieuwe situatie' moeten oplossingen geobjectiveerd op waarde geschat worden en de maat worden genomen aan de hand van meer of minder abstracte beoordelingscriteria. Het ontwerpen van beoordelingsprotocollen kan beoordelaars hierbij houvast geven. Bedenk hierbij dat je bewust en gerechtvaardigd onderscheid wil maken. Doel is om van 'veel' mogelijke aanbieders (gegadigden) te komen tot 'weinig' inschrijvers en uiteindelijk tot 'één' partij die je wenst te contracteren.

Geef aannemers de ruimte eigen oplossingen in te brengen. Daarvoor zullen ze zich meer verantwoordelijk voelen en deze oplossingen tot een succes willen maken. Laat aannemers dus in een vroeg stadium meedenken over 'slimme oplossingen'. Het commitment dat aannemers voelen bij de oplossingen die ze zelf ingebracht hebben, draagt ertoe bij dat trots en vakmanschap zullen zorgdragen voor kwalitatief goede uitvoering. Bovendien profiteer je zo als opdrachtgever van de meest recente ervaringen en innovaties. Ook bestrijd je hiermee de strikte scheiding tussen denken en doen; aannemers kunnen zodoende ook waarde toevoegen aan het project. Ook kunnen aannemers op deze wijze een project 'naar hun hand zetten' wat kwaliteitsverhogend kan werken en efficiency bevordert.

Hanteer een systeem waarin goede (past) performance bijdraagt aan betere kansen op vervolgopdrachten. Dat bevordert de kwaliteit van de samenwerking. Laat het 'reputatiemechnisme' dus haar werk doen. Dit draagt ertoe bij dat aannemers hun performance willen professionaliseren en verbeteren (opportunistisch gedrag past niet bij deze mindset). Laat aannemers vooraf nadenken over risico's, remedies en mogelijkheden om waarde toe te voegen. Dat leidt ertoe dat beter ingespeeld kan worden op zich voordoende zaken tijdens de bouw en dat de value (for money) van het project wordt verhoogd.

Laat alleen relevante data die zoveel mogelijk numeriek (countable facts and figures) gemaakt kan worden, leiden tot onderscheidend vermogen. Zorg dat er tijdens de aanbesteding, maar ook na de contact- en contractfase performance data beschikbaar is zodat 'meten, weten, verbeteren' op een efficiënte en geobjectiveerde manier mogelijk is. Besteed bij de bemensing van projecten ook aandacht aan de informatieverwerkingscapaciteit van medewerkers.

Aanbeveling voor opdrachtgevers 3 .

Zorg ervoor dat het nieuwe aanbestedings paradigma dat ten grondslag ligt aan Best Value Procurement, gekend en begrepen wordt door bij de aanbesteding betrokken functionarissen.

\section{Aanbeveling voor opdrachtgevers 4.}

Deel informatie met marktpartijen die ertoe kan bijdragen dat ze een aanbieding kunnen maken die de meeste waarde biedt binnen het budget dat jij je kunt veroorloven.

\section{Aanbeveling voor opdrachtgevers 5.}

Geef marktpartijen de ruimte om waarde toe te voegen. Dat kan door een oplossingsvrij geformuleerde vraagstelling te hanteren, optimalisaties te stimuleren en partijen in een vroeg stadium te betrekken.

\section{Aanbeveling voor opdrachtgevers 6 .}

Laat in het verleden gerealiseerde prestaties (binnen planning en budget opgeleverd? Naar tevredenheid opdrachtgever? Goed samengewerkt? Flexibel opgesteld?) meewegen bij de selectie van marktpartijen.

Aanbeveling voor opdrachtgevers 7.

Laat marktpartijen in een vroeg stadium nadenken over projectrisico's en over hoe ze die denken te managen. 
Aanbeveling voor opdrachtgevers 8 .

Focus op relevante informatie en op het vermogen om die informatie slim en snel te kunnen duiden, verwerken en toepassen.

\section{Aanbevelingen voor opdrachtnemers}

Ten aanzien van 'anders aanbesteden':

Realiseer je in voldoende mate dat opdrachtgevers die voor een innovatieve aanpak à la pips kiezen, andere vragen stellen. Simpelweg afprijzen wat anderen bedacht hebben volstaat niet meer. Je wint een dergelijke aanbesteding niet door de goedkoopste te zijn maar 'de beste'. De opdrachtgever zoekt een 'bewezen competente partij', die een oplossing biedt die naadloos aansluit bij zijn vraag, de meeste value for money biedt binnen het budget dat hij zich kan veroorloven. Dus moet je je als opdrachtnemer veel intensiever inleven in de klantvraag (en misschien wel in 'de vraag achter de vraag'). Daarvoor is het nodig kennis te nemen van zijn noden, belangen en driifveren; wat is zijn leitmotiv? Dat vraagt om een visie van de zijde van de opdrachtnemer: welke oplossing is de meest passende in deze situatie, voor deze opdrachtgever, met deze vraag? Opdrachtgevers doen dus een appèl op vakmanschap en creativiteit. Dat is een belangrijke verandering vergeleken bij de traditionele situatie. Dat heeft ook invloed op de medewerkers en bijbehorende competenties die nodig zijn om succesvol te kunnen zijn in een dergelijk traject. Houd daar bij de selectie rekening mee en equipeer deze mensen zodat ze uitgerust en toegerust zijn voor deze taken.

Wanneer er om past performance information wordt gevraagd, besteed dan voldoende aandacht aan de gerealiseerde uitkomsten (is binnen planning en budget opgeleverd wat overeengekomen is?). Maar besteed zeker zo veel aandacht aan de weg daarnaartoe (het proces): is er goed samengewerkt, welke problemen zijn getackeld en hoe? Welke initiatieven heb je daartoe genomen en waartoe heeft dat geleid? Wat kun je zeggen over je eigen opstelling (initiatief, coulance, flexibiliteit) in relatie tot het projectresultaat?

Wanneer opdrachtgevers besluiten in het kader van een aanbestedings- procedure sleutelfunctionarissen te willen interviewen, zorg dan voor een projectleider die in staat is aannemelijk te maken dat hij/zij beschik over de voor dit project benodigde competenties, zowel inhoudelijk qua samenwerking en qua sociaal communicatieve vaardigheden.

\section{Aanbeveling voor opdrachtnemers 1.}

Zorg ervoor dat het nieuwe aanbestedings paradigma dat ten grondslag ligt aan Best Value Procurement gekend en begrepen wordt doo bij de aanbesteding betrokken functionarissen.

Aanbeveling voor opdrachtnemers 2.

Zorg dat het team dat de bieding maakt over de competenties beschikt die nodig zijn om goed om te kunnen gaan met andere en nieuwe vragen.

Aanbeveling voor opdrachtgevers 3 .

Besteed bij PPI aandacht aan resultaat en aan het proces dat tot dat resultaat heeft geleid.

\section{Aanbeveling voor opdrachtnemers 4}

Zorg dat te interviewen sleutelfunctionarissen voldoende 'in het project zitten' en dat hun vakinhoudelijke en sociaal communicatieve competenties aansluiten bij wat dit project vraagt en evenwichtig zijn ontwikkeld. 


\section{reflecties en}

\section{bijdragen}

8.o Inleiding

Terugblikken aan het einde van een onderzoek als dit, ligt voor de hand. Hoe verhouden de onderzoeksresultaten zich tot de bij aanvang geformuleerde vooronderstellingen? Hoe is het proces verlopen, wat heb ik ervan geleerd en wat zou ik een volgende keer anders doen? Wat is mee- en wat is tegengevallen? Maar ook terugblikken met het oog op de onderzoeksmethoden, de planning en structurering ervan komt in dit hoofdstuk aan de orde. Daarnaast dringt de vraag zich op: wat heb ik nu eigenlijk bijgedragen? Liggen er nu zaken (inzichten, modellen, resultaten) die er vóór dit onderzoek nog niet waren en in hoeverre hebben die zaken betekenis? Daarbij wordt stilgestaan in de tweede paragraaf van dit afsluitende hoofdstuk. 
Hier volgt een beknopte methodologische reflectie, gericht op de hoofdstukken twee tot en met zes. Deze reflectie heeft als doel te verifiëren of de verschillende onderzoeksstappen 'volgens de regels der kunst' hebben plaatsgevonden en eventuele tekortkomingen daarin te ontdekken en te bezien of daarmee in voldoende mate rekening is gehouden.

\section{Verificatie hoofdstuk twee:}

\section{Wat is pips en tot welke resultaten leidt pips?}

Tijdens de eerste onderzoeksfasen is mijn onderzoekshouding ten opzichte van pips te weinig kritisch geweest. Waarschijnlijke oorzaak ligt in de keuze om eerst veel publicaties van Kashiwagi te lezen en pas daarna te divergeren naar andere auteurs en andere (NIE) theorieen dan de door Kashiwagi gebruikte denkramen. Daarnaast heeft het sinds 2005 toepassen van Pips in Nederland ook voor aanvullend inzicht in de methodiek gezorgd. Zodoende zijn methodologische valkuilen als te gering en/of te eenzijdig bronnenonderzoek uiteindelijk omzeild. Het antwoord op het tweede deel van de vraag is gezocht door de resultaten van 400 pips aanbestedingen in de Verenigde Staten te analyseren en ook de resultaten van de praktijkcases in ogenschouw te nemen. Daarnaast is door uitgebreid literatuuronderzoek een beeld gevormd van de resultaten die de traditionele aanpak (op aspecten als opleveren binnen planning en budget, kwaliteit van samenwerking) oplevert. Op deze wijze is duidelijk geworden dat de pips resultaten een wenkend perspectief voor de sector vormen.

\section{Verificatie hoofdstuk drie:}

Kunnen Pips resultaten met behulp van NIE worden verklaard? Naast een analyse van de theorieën waarop Kashiwagi zijn verklaringen baseert, is aanvullende verklaringskracht gezocht bij New Institutional Economics (NIE). Daarbij is eerst getoetst of deze NIE algemeen erkende en vitale theorieën zijn. Tevens is beredeneerd of toepassing van deze theorieën passend is bij deze vraagstelling. NIE bleken vitaal en algemeen erkend te zijn en goed toepasbaar om aanvullende verklaringskracht te vinden voor de werking van pips. Dit heeft geresulteerd in een theoretisch model. Dit model is via een combinatie van logische redeneringen en verwijzing naar erkende bronnen tot stand gekomen.

\section{Verificatie hoofdstuk vier:}

pips en het geldende juridische kader

Ook voor dit hoofdstuk heeft de oorspronkelijke bron (het BAO) aan de basis gestaan. Daarnaast is gebruik gemaakt van toelichtende teksten en ook de in opdracht van de Regieraad Bouw uitgebrachte 'Leidraad aanbesteden voor de bouw' (onder eind redactie van prof. mr. C.E.C. Jansen) is een waardevolle en algemeen erkende bron geweest die naast kaders, inzichten en overwegingen omtrent rechtmatigheid ook aandacht besteedt aan doelmatigheid. Door middel van logische redene-

ringen is de (mis)match tussen pips en het wetgevend kader in beeld gebracht. Deze bevindingen zijn tevens getoetst aan de inzichten van een aantal in aanbestedingsrecht gespecialiseerde juristen. Op deze wijze is duidelijk geworden voor welke pips elementen de toepasbaarheid geen issue hoeft te zijn; daarnaast is ook duidelijk geworden dat er met betrekking tot het interviewen van sleutelfunctionarissen in de gunningsfase nog volop discussie bestaat. Op punten waar sprake is van uiteenlopende visies en interpretaties zijn conclusies met de nodige terughoudendheid geformuleerd.

\section{Verificatie hoofdstuk vijf:}

\section{toepassing van pips bij praktijkcases}

In het kader van dit onderzoek is een aantal real life aanbestedingen op basis van pips uitgevoerd. De uitkomsten van deze praktijkcases liggen in lijn der verwachting (en deze verwachting is ontleend aan het op NIE gebaseerde theoretische model). Het aantal is echter nog te gering om de uitkomsten te kunnen generaliseren. Bovendien bleken enkele projecten minder geschikt voor de pips aanpak. Ook zijn er zoals in hoofdstuk vijf beschreven, enkele methodologische kwetsbaarheden aan de orde. Daardoor is de zeggingskracht van enkele praktijkcases gering. Om die redenen (gering aantal cases en enkelen daarvan 
beperkte zeggingskracht) is het kwantitatieve onderzoek toegevoegd aan het oorspronkelijke onderzoeksplan. De redenering luidt dat wanneer ook (naast de praktijkcases) de resultaten van het kwantitatieve onderzoek in dezelfde richting wijzen als het theoretisch model vooronderstelt, extra power aan de onderzoeksconclusies wordt toegevoegd.

\section{Verificatie hoofdstuk zes:}

validatie van theoretische bevindingen door kwantitatief onderzoek Het kwantitatieve onderzoek is gebaseerd op een nadere concretisering van het theoretisch model uit hoofdstuk drie. Dit onderzoek is gericht op zowel opdrachtgevers- als opdrachtnemers zijde. Het betreft echter geen a selecte steekproef; dit beperkt de generaliseerbaarheid van de onderzoeksresultaten (wel is het zo dat respondenten met weinig ervaring niet wezenlijk anders antwoorden vergeleken met respondenten met veel ervaring. Deze constatering komt de generaliseerbaarheid juist weer ten goede). Het aantal geënquêteerde projectleiders en de procentuele respons voldoen aan richtlijnen voor onderzoek. De verdeling van de respondenten over de verschillende categorieën is echter dermate excentrisch, dat inzoomen op verschillen tussen deze categorieën maar beperkt mogelijk is. Conclusies naar aanleiding van dit onderzoeksdeel zijn dan ook met enige terughoudendheid geformuleerd.

\subsection{Terugkoppeling onderzoeksresultaten naar vooronderstellingen}

In deze paragraaf wordt verduidelijkt in welke mate de onderzoeksuitkomsten de sturende vooronderstellingen (uit hoofdstuk één) onderschrijven danwel tegenspreken. Daartoe worden relaties gelegd tussen de onderzoeksresultaten uit de voorgaande hoofdstukken en deze sturende vooronderstellingen. Daarbij wordt teruggegrepen op de verkenningen rondom de traditionele aanpak, de introductie en evaluatie van pips en de verbindingen die gelegd zijn tussen pips en NIE uitmondend in het theoretisch model. Ook naar het onderzoek naar de juridische inpasbaarheid, de praktijkcases en het kwantitatieve onderzoek wordt teruggegrepen. Op deze wijze wordt invulling gegeven aan het 'verificatie vraagstuk'; geeft dit onderzoek ook daadwerkelijk antwoord op de onderzoeksvraag en de daarvan afgeleide sturende vooronderstellingen?

De eerste sturende vooronderstelling gaat in op de effectiviteit van pips:

$n r 1$ pips is waardevol voor de Nederlandse Bouwsector.

pips resultaten vormen een wenkend perspectief voor de sector Dat blijkt uit de usA resultaten (hoofdstuk drie) alsmede het verloop en de uitkomsten van de praktijkcases (hoofdstuk vijf). Ook de inzichten die het kwantitatieve hoofdstuk oplevert wijzen voor drie van de vier centrale vragen in dezelfde richting als het theoretisch model voorspelt. Wel is het belangrijk te checken of projecten en projectaanpakken zich wel lenen voor een pips aanpak. De eerste vooronderstelling behoeft dan ook nuancering: Pips is waardevol voor projecten die zich lenen voor een BVP aanpak

$n r 2$ NIE kan de werking van PiPs overtuigend verklaren NIE voegt aan de IMT/KSM verklaring die vooral gericht is op de informatiefactor (slim geselecteerde en vlot verwerkte informatie draagt bij aan het nemen van de juiste beslissingen) economische dimensies en drijfveren toe. Vanuit dit economisch perspectief is 'ander gedrag' veroorzaakt door het toepassen van pips elementen goed te verklaren met behulp van de beschreven mechanismen. Dit onderzoek biedt nog in onvoldoende mate verklaring voor het feit dat opdrachtnemers sceptisch zijn ten aanzien van het ontmoedigen van de neiging tot het vertonen van opportunistisch gedrag bij opdrachtgevers (zie ook vooronderstelling vijf).

De tweede vooronderstelling behoeft dan ook nuancering: Het kwantitatieve onderzoek heeft als resultaat dat drie van de vier centrale vragen bevestigd worden, terwijl de vierde vraag nie tot een duidelijke bevestiging leidt: NIE kan de werking van pips grotendeels overtuigend verklaren. 
De derde sturende vooronderstelling gaat in op de toepasbaarheid van pips elementen tijdens aanbestedingen:

\section{${ }^{n r} 3$ Het juridisch kader biedt voldoende ruimte om pips toe te} kunnen passen

${ }^{99}$ In tegenstelling tot de algemene opvattingen.

De onderzoeksresultaten op dit gebied geven weer dat er ${ }^{99}$ royale mogelijkheden zijn om pips toe te passen binnen het in Nederland geldende wettelijke kader. Een PiPs element (PCR) is in conflict met het geldend juridisch kader en aan enkele andere elementen zijn voorwaarden verbonden.

Alles overwegende wordt deze derde vooronderstelling door dit onderzoek bevestigd: Het juridisch kader biedt voldoende ruimte om pips toe te kunnen passen.

De vierde vooronderstelling heeft betrekking op de onderzoeksresultaten van de praktijkcases:

\section{${ }^{n r} 4$ Praktijkcases laten resultaten zien die op basis van het} theoretisch model te verwachten zijn.

De vier in dit proefschrift beschreven praktijkcases hebben alle geleid tot oplevering binnen budget, binnen planning en naar tevredenheid. De aanbestedingen bleken een groot voorspelbaar vermogen te hebben (als tegenpool voor veel onzekerheid). Uit de beschrijvingen blijkt tevens dat er sprake is van goede en cooperatieve samenwerking (als tegenpool van opportunistisch gedrag). Met andere woorden: Praktijkcases laten resultaten zien die op basis van het theoretisch model te verwachten zijn.

De vijfde en laatste sturende vooronderstelling gaat in op de vraag in welke mate het kwantitatieve onderzoek de werking van het theoretisch model onderschrijft

${ }^{n r} 5$ Het kwantitatief onderzoek laat zien dat 'de praktijk' de werking van het theoretisch model onderschrijft.

De onderzoeksresultaten op dit gebied onderschrijven drie van de vier centrale vragen uit het kwantitatief onderzoek in hoge mate. Het kwantitatief onderzoek onderschrijft de theoretische redeneringen als het gaat om reductie van onzekerheid voor opdrachtgevers en ontmoediging van de neging tot opportunistisch gedrag van aannemers na gunning. Ook opdrachtnemers geven aan dat toepassing van pips elementen hun onzekerheid zal reduceren. Ze zijn echter sceptisch als het gaat om de effecten ten aanzien van het ontmoedigen van opportunistisch gedrag van opdrachtgevers.

Deze scepsis wordt waarschijnlijk gevoed door de ervaring van de afgelopen decennia waarin opdrachtgevers in toenemende mate 'voor een dubbeltje op de eerste rang wilden zitten'. De uitspraken van respondenten zijn voor een deel gebaseerd op feitelijke ervaringen hieromtrent, maar voor een groter deel op verwachtingen. Meer onderzoek op dit punt is nodig.

Omdat antwoorden van respondenten voor het merendeel zijn gebaseerd op verwachtingen (en (nog) niet op ervaringen) en omdat één van de vier mechanismen maar deels onderschreven wordt, wordt deze veronderstelling niet overtuigend en ook niet integraal onderschreven. Er zal aanvullend onderzoek nodig zijn om te bezien in hoeverre de positieve tendenties bestendigd worden en de sceptische houding van opdrachtnemers op basis van positieve ervaringen af zal nemen: Het

kwantitatief onderzoek laat zien dat 'de praktijk' de werking van het theoretisch model grotendeels onderschrijft.

De eerste twee sturende vooronderstellingen behoeven nuancering, maar blijven in de kern 'overeind'. De derde en vierde worden onderschreven. Bij vijfde vooronderstelling is dit slechts deels het geval. E zijn wel stevige indicaties die wijzen in de richting van deze vooronderstelling, maar evidence based uitspraken zijn er nog niet of nog in te geringe mate. Deze indicaties zijn van zodanige aard dat verder onderzoek op genoemde punten nodig én gerechtvaardigd is.

De terugkoppeling naar de initiele onderzoeksvraag: "Het is toch te gek dat er onvoldoende zicht is op de waarde van pips voor de Nederlandse Bouwsector" levert aan het einde van dit onderzoek het volgende beeld op:

- Er is voldoende zicht op de aanleidingen om veranderingen door te 
voeren en ook in welke richtingen die veranderingen zouden moeten plaatsvinden: de traditionele aanpak komt te kort voor veel van de hedendaagse bouwopgaven.

- Er is voldoende zicht op de methodiek en de resultaten die pips tot gevolg heeft: pips wise aangepakte projecten scoren bij geschikte projecten duidelijk beter op het gebied van percentage projecten binnen planning, binnen budget, samenwerking, opdrachtgeverstevredenheid en de hoeveelheid managementinspanning aan opdrachtgeverszijde.

- Er is voldoende zicht op een op erkende theorieën gebaseerde verklaring van de werking: het theoretisch model dat beschrijft dat het toepassen van pips safeguards onzekerheid reduceert en de neiging tot het vertonen van opportunistisch gedrag ontmoedigt en daarmee bij draagt aan projectsucces.

- Er is voldoende zicht op de juridische toepassingsmogelijkheden binnen het geldende wetgevende kader en deze mogelijkheden zijn ook voor anbestedende diensten royaal aanwezig.

- Praktijkcases in Nederland zijn alle binnen planning en budget en naar tevredenheid opgeleverd, behoudens situationele factoren die buiten de invloedssfeer van de aanbesteding vallen. Daarmee is er nog niet voldoende zicht op de werking in de praktijk omdat het aantal cases nog te gering is. Wel wijzen de cases in dezelfde richting van de in het verkennende onderzoek betrokken aanbestedingen in de Verenigde Saten en het theoretisch model.

- 'De praktijk' verwacht dat toepassing van pips elementen zal leiden tot gereduceerde onzekerheid voor opdrachtgevers en opdrachtnemers. Ook zal de neiging tot het vertonen van opportunistisch gedrag door opdrachtnemers ontmoedigd worden. Opdrachtnemers verwachten nauwelijks effecten van het toepassen van pips elementen op het ontmoedigen van opportunistisch gedrag van opdrachtgevers. Er zijn geen significante verschillen gevonden tussen antwoorden van respondenten met minder ervaring ten opzichte van respondenten met meer ervaring met pips elementen.
Concluderend:

Het totale beeld doet mij concluderen dat er nu een gedegen verklaring voor de werking van PiPS voorhanden is en dat toepassing van PiPs bijdraagt aan in en door de sector gewenste veranderingen. "Het is toch te gek dat..." is hiermee opgelost, en de vraag of pips waardevol is voor de Nederlandse Bouwsector kan positief beantwooord worden:

PiPs kan bij daarvoor geschikte projecten van grote waarde zijn voor de Nederlandse Bouwsector.

En voorzover de antwoorden aan het einde van dit onderzoek nog niet bevredigend zijn, is aangegeven welke vervolgonderzoeken aanbevolen worden.

\subsection{Reflecties}

\section{Reflecties ten aanzien van de methodiek/aanpak}

Naast de bij 8.1 beschreven items is nog een aantal algemene reflectieve opmerkingen te plaatsen bij de gehanteerde methodiek/aanpak. Terugkijkend valt te concluderen dat in het begin van het onderzoekstraject meer aandacht had moeten besteden aan de onderzoeks structuur. Het ontwerpen van het onderzoek kan pas wanneer er voldoende overzich is over de gehele problematiek. De drive om in een vroeg stadium vooral 'meters te willen maken', blijkt contraproductief te zijn. Het is effectiever en uiteindelijk ook efficiënter, eerst meer tijd en aandacht te besteden aan het onderzoeksontwerp. Dan was de chronologie en structuur fraaier geweest, was het kwantitatief onderzoek waarschijnlijk van meet af aan ingebouwd en had het op theorie gebaseerde model zijn nut ook al kunnen bewijzen tijdens de eerste praktijkcases. Nu heeft het model alleen achteraf geholpen bij het begrijpen van hoe en wat er gebeurde. Ook bij het schrijven van het proefschrift (de verslaglegging van het onderzoek) moet ik achteraf constateren dat ik te vroeg begonnen ben. Dat heeft vele versies van bepaalde hoofdstukken opgeleverd waarin telkens de voortschrijdende inzichten ingebouwd moesten worden en de interne consistentie bewaakt moest worden. Dat heeft (te) veel tijd gekost.

De statistische verwerking van het kwantitatieve onderzoek heb ik opgepakt op basis van zelfstudie en het raadplegen van enkele collega's 
die vaardig zijn in het toepassen van statistische toetsen. Achteraf bezien was het waardevol geweest als ik daarvoor wat meer scholing gevolgd zou hebben. Dan had ik ook hier doelgerichter te werk kunnen gaan.

\section{Reflectie ten aanzien van het proces}

De start van dit promotieonderzoek is via een geleidelijk pad verlopen. Eerst was er het vooronderzoek in 2003/2004. Daarna volgden de deelonderzoeken die hoofdzakelijk (onder mijn leiding) uitgevoerd zijn door Bachelor en Master studenten. Begin 2005 voerde ik het eerste gesprek met André Dorée omtrent de vraag of een promotieonderzoek binnen mijn bereik zou kunnen liggen. Vanaf medio 2005 tot en met 2009 ben ik meer dan halftime met dit onderzoek bezig geweest wat ik als uitermate boeiend en verrijkend heb ervaren. Vanaf 2010 is de intensiteit minder geweest en heb ik naast mijn volle taakplaat als senior docent en parttime aanstelling als consultant voornamelijk's avonds, in de weekends en in vakanties aan het onderzoek gewerkt. Daarnaast heb ik sinds 2010 nog een tiental innovatieve aanbestedingstrajecten mogen ontwerpen en begeleiden (zie Bijlage $\mathrm{x}$ ), waarbij de tijdens dit onderzoek opgedane inzichten bruikbaar en effectief bleken. Hoewel deze aanbestedingen niet in dit proefschrift zijn beschreven, is het vermeldenswaardig dat ook deze aanbestedingen zonder juridische geschillen tot het gewenste resultaat hebben geleid en het theoretisch model duidelijk waarneembaar actief bleek.

Bij dit onderzoek speelde de afhankelijkheid van de medewerking van anderen een factor van belang, zowel planningstechnisch als inhoudelijk. Dit is bijvoorbeeld duidelijk gebleken bij de voorbereidingen van het kwantitatieve onderzoek. Het bleek lastig te zijn om voldoende deelnemers aan de online-enqûete te recruteren. Daar ben je zo maar enkele maanden mee kwijt.

Achteraf gezien had dit, als zogenoemde buitenpromovendus uitgevoerde, onderzoek efficiënter uitgevoerd kunnen worden, maar dan had ik leermomenten gemist die nu bijgedragen hebben aan academische vorming. Het in hoge mate zelfstandig uitvoeren van dit onderzoek, en ook het doormaken van de trial and error zijsporen, heeft zo veel opgeleverd, dat ik er achteraf met een positief gevoel op terugkijk. Het zelfstandig doen van wetenschappelijk onderzoek is als proces waardevol gebleken en het resultaat (de inzichten zoals verwoord in dit proefschrift) van dat proces levert een bijdrage aan de gewenste veranderingen in de sector. Immers de positieve pips resultaten zijn nu op basis van vitale erkende theorieën te verklaren, de juridische toepasbaarheid is in beeld en de praktijkcases bevestigen de meerwaarde van de pips aanpak.

De wetenschappelijke vorming die het uitvoeren van dit onderzoek en het schrijven van dit proefschrift heeft opgeleverd, vormt een verrijkin voor mijn toekomstig werk. Onderzoek dat ik zal uitvoeren en/of coördineren zal er zeker meer solide van worden waardoor de resultaten ervan meer power zullen hebben. Bij toekomstig onderzoek zal ik ingegeven door de leermomenten en ervaringen opgedaan tijdens dit traject, speciale aandacht besteden aan:

- De onderzoeksvraag: is er sprake van een concrete en zuivere vraagstelling?

- Afbakening en focus: voldoende richtinggevend zodat voldoende diepgang moeglijk is?

- Onderzoeksontwerp: voldoende helder en 'stevig', passend bij de vraag, wordt een logische redeneerlijn gevormd?

- Validiteit: meten we ook daadwerkelijk wat we beogen te meten?

- Betrouwbaarheid: in welke mate is er sprake van stabiliteit van onderzoeksresultaten?

- Fundamenten: wordt er in voldoende mate een beroep gedaan op 'autoriteit', feiten, logica en algemeen erkende kennis?

- Gerechtvaardigde conclusies: is de relatie tussen analyse resultaten en geformuleerde conclusies voldoende straight en tight?

Wanneer aan de hand van deze leidende principes onderzoek word gedaan, zullen onderzoeksresultaten voldoende zeggingskracht hebben en zullen ze kwalitatief hoogstaand zijn. Immers:

"quality is never an accident; it is always the result of high intentions, sincere effort, intelligent direction and skilful execution; it represents the wise choice of many alternatives" (William Foster) 


\subsection{Bijdragen}

In deze paragraaf worden de bijdragen van dit onderzoek weergegeven. De bijdragen worden gerubriceerd naar bijdragen aan het wetenschappelijk debat, bijdragen aan de aanbestedingspraktijk en bijdragen aan toekomstige onderzoeksagenda’s.

\section{Bijdragen aan het wetenschappelijk debat}

De pips methodiek en de daaraan door de ontwikkelaar ervan gekoppelde effectclaims zijn onderzocht en naar aanleiding daarvan op een aantal punten genuanceerd.

De werking van de methodiek is onderzocht en voorzien van een stevig theoretisch fundament. NIE theorieën zijn gekoppeld aan pips wat heeft geleid tot een model waarin de centrale mechanismen (reduceren van onzekerheid en ontmoedigen van de neiging tot opportunistisch gedrag) solide en aanvullende verklaringskracht brengen ten opzichte van de door Kashiwagi gepresenteerde verklaringen.

\section{Bijdragen aan de aanbestedingspraktijk}

Dankzij de combinatie van theorievormend onderzoek, actieonderzoek (praktijkcases) en kwantitatief validerend onderzoek, biedt dit onderzoek houvast voor beleidsmakers, onderwijs, opdrachtgevers en opdrachtnemers en kan dit onderzoek bijdragen tot de beoogde veranderingen in de sector.

De belangriikste signalen voor beleidsmakers zijn: ontmoedig het gebruiken van 'de-laagste-prijsklem', bevorder het hanteren van oplossingvrij geformuleerde vraagstellingen en maak duidelijk dat het juridisch kader voldoende ruimte biedt om innovatief aan te besteden. Voor het onderwijs is belangrijk dat het nieuwe aanbestedingsparadigma ingebouwd wordt in curricula van opleidingen rondom het thema built environment en voor opleidingen waarbij het make, buy or ally thema een belangrijke rol speelt. Voor de belangrijkste aanbevelingen voor opdrachtgevers en opdrachtnemers wordt hier verwezen naar de aanbevelingen uit hoofdstuk zeven.

Uitgebreide studie van internationale wetenschappelijke bronnen die de manco's die samenhangen met de traditionele aanpak beschrijven en aantonen is hier bijeengebracht wat geleid heeft tot een handzaam en hanteerbaar overzicht ervan (Bijlage I).

De juridische inpasbaarheid van de pips elementen binnen het nu geldende kader is in beeld. Op een groot aantal punten zijn er gelijkluidende opvattingen en interpretaties. Ten aanzien van het interviewen van sleutelfunctionarissen in de gunningsfase duurt de discussie nog voort. In tegenstelling tot de algemeen gangbare gedachte is gebleken dat er (ook voor aanbestedingsplichtige diensten) goede mogelijkheden zijn om pips toe te passen. De wijze waarop dat kan is voor twee varianten ontwikkeld, getoetst en toegepast. Deze procesontwerpen zijn nu beschikbaar voor opdrachtgevers die een aanbesteding volgen de niet openbare procedure willen doen.

Het mee laten wegen van de kwaliteit van prestaties uit het verleden kan naar aanleiding van dit onderzoek niet alleen op de 'Kashiwagi' manier (met daaraan verbonden bezwaren ten aanzien van proportionalitei en objectiviteit), maar ook op een wijze die tegemoet komt aan deze bezwaren en bovendien meer informatie geeft over competenties die relevant zijn voor dit project en de karakteristieke elementen daarvan.

\section{Bijdragen aan toekomstige onderzoeksagenda's}

Naast de 'harde conclusies' zijn er aan het einde van dit onderzoek nog enkele items die om verder onderzoek vragen. De belangrijkste samengevat:

- In hoeverre kloppen de indicaties dat opdrachtnemers ook positief staan tegenover de toepassing van pips? In welke mate kunnen ze door aanvullend onderzoek bevestigd worden, of moeten ze verworpen worden en ingeruild worden voor andere inzichten?

- Klopt de veronderstelling dat de terughoudendheid bij opdrachtnemers ten aanzien van het ontmoedigen van de neiging tot opportunistisch gedrag bij opdrachtgevers veroorzaakt wordt door scepsis op grond van de ervaringen van de afgelopen decennia? Zo ja; hoe kan deze scepsis worden weggenomen? Zo nee; waardoor wordt deze scepsis dan veroorzaakt?

- In hoeverre klopt de veronderstelling dat pips ook succesvol toepasbaar is in andere sectoren? Waar vooral? Waar niet? Zijn er dan aanpassingen nodig, en waarom?

- Klopt de indicatie dat de reductie van benodigde managementcapaciteit 
aan opdrachtgeverszijde enkele tientallen procenten bedraagt? Wat zijn de belangrijkste variabelen in dit kader en kan er met behulp van een model op voorhand een schatting gemaakt worden van de te verwachten besparing?

- Is de juridische toepasbaarheid van pips 'houdbaar' in het licht van de nieuwe aanbestedingswet en toekomstige jurisprudentie op dit terrein? Hoe verhoudt de opgewaardeerde rol voor de pre-award fase zich tot het juridisch kader?

- Hoe kan toepassing van pips binnen de Bouwsector worden bevorderd? Welke belangen heeft Bouwend Nederland in dit kader? Welke belangen hebben publieke en private opdrachtgevers in dit kader? Hoe kunnen overheidsopdrachtgevers in dezen een voorbeeldrol vervullen? Kan Pianoo bijvoorbeeld een stimulerende rol vervullen? Waar stopt de bemoeienis van de overheid en waar moet 'de markt' het overnemen?

- Liggen pips aanbestedingen qua administratieve workload en inhoudelijke competenties binnen het мкв bereik?

\section{summary}

9.0

\section{Clarifying the Value of PiPs for the Dutch Construction Industry}

In the first decade of this century, many initiatives were taken to improve the cooperation between client and contractor, to decrease failure costs and to professionalize the construction industry. Together with the 'PSiBouw' program and 'Regieraad Bouw, the Performance information Procurement System (PiPs) was introduced in the

Netherlands. Remarkable results were reported from the UsA; projects that deliver on budget, on time and that meet the client's expectations are pips standards. The existing clarification for success is only based upon the information factor (the more relevant data is being efficiently processed and used, the more likely it is that wrong decisions will be prevented). The central goal of this $\mathrm{PhD}$ research is to provide clarification for success based upon acknowledged theories.

Therefore the core research question is: how can pips results be clarified?

Or in other terms: what mechanisms cause pips successes?

\section{A brief introduction to pips}

A pips tender contains several elements/filters which this research interpretes as safeguards. A safeguard is a measure that is intended to reduce uncertainty and/or decrease the inclination toward opportunistic behavior. Safeguards are important components of New Institutional Economics (NIE) and this approach is an important starting point for answering the research question.

This research considers the following safeguards, sorted into the contact-, contract- and control stage. Wherever "Pips filter" is added, the safeguard is one of Kashiwagi's original filters: 


\section{Contact stage:}

- Functional specifications

- Sharing information about maximum budget

- Past performance information; pips filter 1

\section{Contract stage:}

- Risk assessment plan/value added; pips filter 2

- Interviewing key personnel; pips filter 3

- $\quad$ Performance/price ratio; pips filter 4

\section{Control stage:}

- Risk transfer; pips filter 5

- Performance management; pips filter 6

- Post construction rating; pips filter 7

\section{Introduction of a theoretical model}

Application of these safeguards reduces uncertainty, decreases the inclination toward opportunistic behavior after the bid has been awarded and decreases the impact of bounded rationality. Bounded rationality leads to decision making which implies that wrong decisions can be made and that bounded rationality can therefor lead to more uncertainty.

Reduced uncertainty and decreased inclination into opportunistic behaviour do both contribute to project success. Uncertainty and opportunistic behavior can occur on the clients's and contractor's side and during the tender process or after it has been awarded. In addition, the application of pips safeguards influences other results (e.g. more efficient processes, decreased transaction costs, professionalizing the branche, and more satistaction with results). Other factors are also in play (e.g. market situation, weather and location). These direct effects are shown as a direct arrow to projectsuccess:
Otherfactors

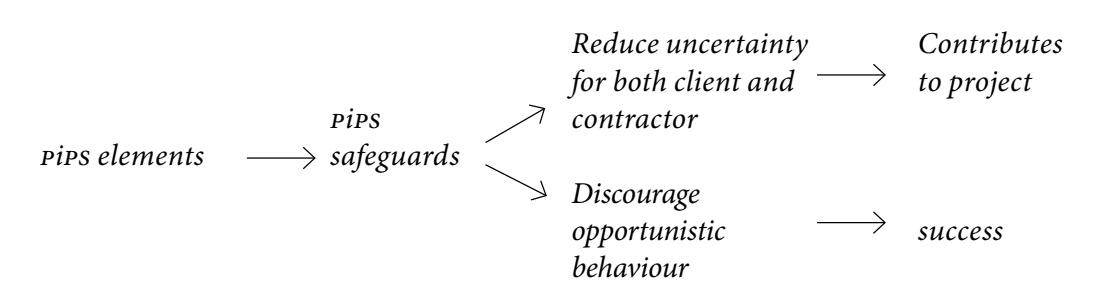

pips and the legal framework

An important precondition for applying pips to the bid process, is that it should not conflict with the applicable legal framework. In the Netherlands, bidding rules are laid out in the Besluit Aanbestedingsregels Overheidsopdrachten (BAO). Nowadys pips is being applied several times, by both public and private clients but this does not necessarily mean that all pips elements fit into the Dutch legal framework. For that reason we investigated whether some pips elements can be applied, some elements can only be applied under certain preconditions or other pips elements can not be legally applied.

The legal framework offers several opportunities for applying innovative elements like pips safeguards. Though pips elements from the contactand contract stage can be applied, some of them require certain preconditions. The legal framework does not regulate the control stage, but one pips safeguard has such a huge impact on future tenders that it conflicts with the law: European public clients cannot apply a Post Construction Rating (PCR). Interviews with key personnel found different advices: some legal experts state that this can not be done at all in the construction management field, but others stress that it can be done in specific circumstances. In all situations European tender principles (i.e. transparency, objectivity and non-discrimination) must be respected. 
pips in practice

Applying pips safeguards in real-life bid cases confirmed the majority of these theoretical premises. When the expected effects did not occur, the reason could be clarified based upon specific circumstances. A quantitative survey was another part of this research. Its objective was to discover whether actually applying pips safeguards would lead to the results forecasted by the theoretical model (i.e. decreases uncertainty and discourages the inclination toward opportunistic behaviour). Survey respondents commonly agreed upon this.

\section{Main conclusions}

Applying pips safeguards decreases client uncertainty. The pips approach brings in more relevant data on which choices can be based. By sharing information about the maximum available budget, the uncertainty and risk of invalid bids is decreased. The risk of selecting an incompetent contractor is reduced by applying past performance information and reviewing risk assessment plans.

Uncertainty about the programme of demands is decreased because the contractor (whose competency is judged based on evidence) is responsible for a solution that fits the use and the user. Uncertainty about contract compliance is decreased because low-bid environment is avoided and performance data is available during the construction stage. In addition to these mechanisms the reputation mechanism also comes into play.

Contractor's uncertainty is reduced because they have more influence on the project and can bring in their own solutions. This makes it possible for them to distinguish themselves in terms of quality and workmanship, and not only in terms of (the lowest) price. A contractor can win a bid because of a clever solution, a suitable project leader and a comprehensive risk assessment plan. Contractors feel more confident because these factors are under their own influence.

Applying pirs safeguards decreases the contractor's inclination toward opportunistic behavior because of value-based awarding (instead of lowest price awarding). This gives contractors the opportunity to share qualities such as excellent workmanshipor, solid materials. Value-based awarding does not require haggling. In a low-bid environment, it is almost necessary to act opportunistically to make a healthy margin.
When contractors feel proud and committed to their own solutions, they are less inclined toward opportunistic behavior. In addition contractors are aware that their performance on a project will influence their chanses for future jobs; this triggers high performance and discourages opportunistic behavior.

According to contractors, opportunistic behavior on the client's side will not be convincingly decreased by the application of pips safeguards. A likely explanation of this finding could be that contractors are skeptical about the behavioral changes clients will make, because for decades they wanted first-rate results for a cheap price.

pips counters bounded rationality because only relevant (and compact/ countable) data is being let in. Only dominant differences are being taken into account. PiPS does not influence the bounded rationality itself, but it does impact its consequences.

\section{Recommendations}

The most important recommendations for science, policy makers, education and practice will be summarized. Science should be used to conduct further research about whether contractors appreciate the pips approach; right now we only have some indications that they appreciate it. For policy makers applying "pips unless..." is the most important message. In the field of professional education, it is recommended that pips insights be built into the curricula that frequently confront "make, buy or ally" issues. Clients should allow contractors to add value to their solutions and contractors should ensure that bid teams have all necessary competences to deal with the different questions that are being asked in a best value bid.

The most important scientific contributions of this research is a solid theoretical grounding that clarifies the pips effects and results. The research also elaborates on how pips fits into the legal framework. In the end it is clear that leaving the low-bid environment often contributes to project success. 


\section{literatuurregister}

Albano, G. Cesi, B. | 2008

"Past performance evaluation in Repeated Procurement: a simple

model of handicapping"

IPPC 2008, conference proceedings.

Alchian et al | 1972

"Production, Information Costs ans Economic Organization"

American Economic Review 62.5, 777 - 795.

Alders, B. | 2002

"het failliet van het traditionele aanbesteden".

Building Business, juni 2002.

Alston, L. J. | 2008

"new institutional economics,"

The New Palgrave Dictionary of Economics, 2nd Edition

Ang, G. $\mid 2004$

"Inventoryof International reforms in building and Construction". VROM, Rijksgebouwendienst.

Ang, G. Groosman, M. Scholten, N. | 2005

"Dutch performance based approach to building regulations and

public procurement"

Building Research \& Information, 33:2, 107 - 119. 
Axelrod, Bajari, P. Houghton, S. Tadelis, S. | 2007,

"Bidding for incomplete contracts: An Empirical Analysis of Adaption Costs".

http://faculty.haas.berkeley.edu/stadelis/incomplete.pdf viewed november 112007

BAO | gepubliceerd op 11 juni 2005 in het Staatsblad 408 van het Koninkrijk de r Nederlanden.

Barlow, J. Cohen, M. Jashapara, A. Simpson, Y. | 1997.

"Towards Positive Partnering"

The Policy Press, Bristol.

Barrett, P. | 2007,

"Revaluing Construction: a holistic model."

Building Research \& Information, 35.3, 268-86.

Bazerman, H. Samuelson, W. | 1983.

"I won the Auction but Don't Want the Price"

The Journal of Conflict Resolution, 27:4, $618-634$.

Bennett, J. Jayes, S. | 1998

"The Seven Pillars of Partnering"

Thomas Telford, London.

Bentum, A. van | 2005

"PiPs made in the USA, ervaringen en effecten uit de vs"

[Pips made in the USA: experiences and effects from the Us].

European Master Facility Management Master's thesis, Saxion,

Deventer.

Berg van den M. Kamminga, P. | 2006

"Optimizing Contracting for alliances in infrastructure projects"

International Construction Law Review, 23:1.
Bijsterveld, K. | 2005,

"Ook de vraagkant moet een beetje worden opgevoed"

Building Business, februari 2005.

Brady, T. Davies, A. Gann, D. | 2005

"Can Integrated solutions business models work in construction?"

Building Research \& Information, 33:6, 571 - 579.

Bremer, W. Kok, K. | 2000,

"The Dutch Construction Industry: a combination of competition and corporatism".

Building Research \& Information, 28, $98-108$.

Boukendour, S. | 2007,

"Preventing Post-contractual opportunism by an option to switch from one contractor to another"

Construction Management and Economics, Volume 25, 723 - 727

Bouwkennis | 2006

"vermindering faalkosten door intensieve samenwerking".

Bremer, W. $\mid 2004$

"Utiliteitsbouw en Marktimperfecties; probleemschets voor de

Regieraad Bouw".

Bresnen, M. | 1991

"Construction Contracting in theory and practise: a case study"

Construction Management and Economics. Volume 9, 247-263.

Bresnen, M. Marshall, N. | 2000

"Partnering in construction: a critical review of issues, problems and dilemmas."

Construction Management and Economics, 18, 229-37.

Briscoe, G. Dainty, A. Millett, S. Neale, R. | 2004

"Client led strategies for construction supply chain improvement"

Construction Management and Economics, 22(2), 193-201. 


\section{Bromiley, P. Cummings, L. 1995}

"Transaction costs in organizations with trust"

Research on Negotiations in Organizations, 5, 219-247.

\section{Butler, J. | 2002}

"Construcion Quality Stinks"

Engineering News Record, 248 (10), 99.

Caerteling, J. Halman, J. Dorée, A. 2008

"Technology Commercialization in Road Infrastructure: How

Government Affects the Variation and Appropriability of Technology" Journal of Product Innovation Management, 25, 143-161.

\section{Caniëls, M. Sijpersma, R. | 2005}

"Procesintegratie en innovatief ondernemerschap in de bouw"

Dutch Economic Institute for the Building Industry EIB in opdracht van PSiBouw.

\section{Caniëls, M. Sijpersma, R. $\mid 2006$}

"Procesintegratie en innovatief ondernemerschap in de bouw"

Dutch Economic Institute for the Building Industry EIB in opdracht van PSiBouw.

Chan, A. Chan, D. Ho, K. $\mid 2003$

"An empirical study of the benefits of construction partnering in Hong Kong"

Construction Management and Economics. Volume 21, 523-533.

Chang, C. Ive, G. | 2007

"reversal of bargaining power in construction projects: meaning, existence and implications".

Construction Management and Economics. Volume 25, 845 - 855 .

Chiang, Y. Tang, B. $\mid 2005$

"Trust, Partnership and power in Construction: Theory and application in Hong Kong"

Construction Procurement, 11(2), 94 - 111.
Chao - Duivis, M. 2005

"De juridische haalbaarheid van de wens gegadigden/inschrijvers te beoordelen op hun past performance"

Kenniscentrum voor Bouwprocesinnovatie TU Delft.

Chao - Duivis, M. 2006

"het beoordelen van aannemers op basis van past performance: een eerste verkenning"

Bouwrecht, Volume 11, 979 - 991.

Cheung, F. et al. | 2005

"Relationships contracting in Australia"

Construction Procurement. Volume 11, 123-135.

Coase, R. | 1937

"The Nature of the Firm"

Economica, 4.

Constantino, N. Falagario, M. Iacobellis, G. $\mid 2008$ "Reducing the costs of public tenders: a modest proposal" IPPC 2008, Conference Proceedings.

Dagenais, D. $\mid 2007$

"Introduction to good faith in construction contracts"

Construction Management and Economics. Volume 25, 715 - 721

Dainty, A. Briscoe, G. Millett, S. | 2001

"Subcontractor perspectives on supply chain alliances"

Construction Management and Economics. Volume 19, 841-848.

Davies, P. | 1992

"The Mind of God"

Simon \& Schuster, New York.

Dirks, K. | 1999

"The effects of interpersonal trust on work group performance"

Applied Psychology, 84(3), 445 - 455 
Dorée, A. | 1996

"Gemeentelijk Aanbesteden"

[Municipal procurement]. $\mathrm{PhD}$ thesis, University of Twente.

Dorée, A. | 2001

"Dobberen tussen concurrentie en co-development"

[Floating between competition and co-development]. Inaugural speech, University of Twente.

Dorée, A. $\mid 2004$

"Collusion in the Dutch construction industry: an industrial organization perspective."

Building Research and Information, 32, 146-56.

Dorée, A. Boes, J. | 2007

"Professioneel Opdrachtgeverschap en Vakmanschap; bestuurlijk ambtelijke barrieres voor invoering geintegreerd uit \& aanbesteden bij decentrale overheden"

PSiBouw, Eindrapport project O-203.

\section{Dreschler, M. Beheshti, M. de Ridder, H. | 2008}

"Improving Value Based Procurement; An analysis of applications of the EMAT award mechanism in the Dutch Construction industry". http://www.tudelft.nl/live/pagina.jsp?id=3522f3c4-05d3-45dc-a7826ezb20676a2ferlang=nl viewed February 10, 2010

Drexler, J. Larson, E. $\mid 2000$

"Partnering: Why project owner-contractor relationships change"

Construction Engineering and Management, 126 (4), 293-297.

Dubois, A. Gadde, L. 2002

"The construction industry as a loosely coupled system: implications for productivity and innovation"

Construction Management and Economics, Vol.20, 621-631.
Duren van J. Dorée, A. | 2007

"Innovatieve selectie van alliantepartners"

Building Business, oktober 2007.

\section{Duren van J. Dorée, A. | 2010}

"An evaluation of the Performance informationProcurement System

(PiPS)"

Journal of Public Procurement Volume 10 (2)

Dyer, J.H. | 1997,

"effective Interfirm Collaboration: How Firms Minimze Transaction Costs and Maximize Transaction Value"

Strategic Management Journal, 18.7, 535- 556

Edkins, A. Smyth, H. $\mid 2006$

"Contractual management in PPP projects: evaluation oflegal versus relational contracting for service delivery"

Journal of Professional Issues in Engineering Education and

Practice 132(1), 82-93

Egan, J. $\mid 1998$

"the Egan Report"

Construction Task Force to the deputy prime minister, John Prescott,

on the scope for improving the quality and efficiency of UK

Construction.

Eisenhardt, K. | 1989

"Agency Theory: An Assessment and Review"

The Academy of Management Review, 14.1, 57 - 74 .

Eriksson, P. Pesamaa, O. $\mid 2007$

"Modelling procurementeffects on cooperation"

Construction Management and Economics. Volume 25, 893- 901.

Fernie, S. Leiringer, Thorpe, T. | 2006

"Change in construction: a critical perspective."

Building Research and Information, 34.2, 91-103. 
Galbraith, J.R. | 1973

"Designing Complex Organizations."

Boston, Addison Wesley Longman Publishing Co.

\section{Gambetta, D. | 1998}

"Trust: making and breaking co-operative relations"

Oxford, Blackwell.

Geyskens, I. Steenkamp, N. Kumar. | 2006

"Make, buy or ally: a transaction cost theory meta-analysis."

Academy of Management Journal, 49.3, 519-43.

Goei, de F. Simons, H. $\mid 2002$

"Transactiekosten in theorie en praktijk. De kosten van het Handelsregister in de zie eeuw"

NEHA jaarboek.

\section{Goddard, M. Mannion R. | 1998}

"From competition to co-operation: new economic relationships in the national health service."

Health Economics, 7, 105-19.

\section{Goldberg, J. Markóczy, L. | 2000}

"Complex rethoric and simple games"

Emergence, journal of complexity Issues in Organizations and

Management, 2 (1), 72 -10o.

Goovaerts, A. Pries, F. $\mid 2006$

"Prestatiegericht samenwerken, een 'andere' manier van aanbesteden" Building Business 2006, 8.

Graafland, J. Nijhof, A. | 2007

"Transparency, market operation and trust in the Dutch Construc-

tion industry: an exploratory study"

Construction Management and Economics. Volume 25, 195- 205.
Graham, I. Chang, C. | 2007

"The principle of inconsistent trinity in the selection of procurement systems"

Construction Management and Economics, Volume 25, 677 - 69 o.

Gransberg, D. Ellicot, M. | 1997

"Best value contracting criteria"

Cost Engineering. Volume 39, 31 - 41.

Greenwood, D. Yates, D. | 2006

"The determants of successful partnering: a transaction cost perspective" Construction Procurement, 12(1), 4- 22.

Gribnau, R. | 2005

"Aanbestedingsreglement Werken 2005"

Grosskopf, B. Bereby, Y. Bazerman, M. | 2003

"On the robustness of the winner's curse phenomenon"

Harvard Business School; $h t t p: / / s s r n . c o m / a b s t r a c t=667369$ viewed

November 23, 2007

Grossman, S. Hart, O. $\mid 1986$

"The Cost and Benefit of Ownership: A Theory of Lateral and Vertical Integration"

Journal of Political Economy, 94, 691-719.

Gruneberg, S. | 2007

"Performance based contracting: an alternative approach to

transacting in construction"

Construction Management and Economics, 25: 111 - 112.

Guccio, C. Pignataro, G. Rizzo, I. | 2008

"Adaption costs in public Works procurement"

IPPC 2008, Amsterdam.

Hart, O. Moore, J. | 1990

"Property Rights and the Nature of the Firm."

Journal of Political Economy, 98(6):1119-1158. 
Haselhoff, F. Rijlaarsdam, E. | 1998

"Het kan best anders in de bouw"

Rapport SBR 166;

\section{Hatush, Z. Skitmore, M. | 1997}

"Criteria for contractor selection"

Cost Engineering. Volume 39, $19-38$

Hovers, J. | 2004

"Van Raad naar Daad; Actieplan op hoofdlijnen"

Regieraad Bouw.

Hovers, J. | 2005

"Van voorbereiding naar uitvoering; Jaarverslag 2004"

Regieraad Bouw.

\section{Hovers, J. | 2006}

"Van uitvoering naar resultaat; Jaarverslag 2005"

Regieraad Bouw.

Ive, G. Chang, C. | 2007

"The principle of inconsistent trinity in the selection of procurement systems"

Construction Management and Economics, 25: 677 - 690.

Jansen, A. et al. $\mid 2007$

"Gunnen op waarde, hoe doe je dat? Praktische benadering voor

bouwopdrachten"

PSiBouw, Gouda.

Jansen, C. $\mid 2001$

"Andere manier van aanbesteden voorkomt bouwkartels"

NJB 2001 afl. 44, p. 2123-2128.

Jansen, C. $\mid 2009$

"Leidraad aanbesteden bouwopdrachten"

http://leidraadaanbesteden.nl
Jansen, C. $\mid 2006$

"Sleutelpublicatie: beter aanbesteden in de bouw"

Regieraad Bouw.

\section{Jansen, F.J. Sijpersma, R. | 2007}

"Opdrachtgevers aan het woord"

Economisch Instituut voor de Bouwnijverheid, Amsterdam.

Jin, X. Ling, F. | 2005

"Constructing a framework for building relationships and trust in project organizations: two case studies of building projects in China" Construction Management and Economics, 23(7), 685- 696

\section{Jonkhoff, W. | 2006}

"Naar een waardevolle aanbesteding"

Towards valuable procurement]. Building Business.

Hawking, S.W. $\mid 1988$

"Wormholes in spacetime"

Journal of Physical Review, Volume 37, 904 - 910.

Holt, G. Olomolaiye, P. Harris, F. | 1995

"A review of contractor selection practise in the UK construction Industry" Building and Environment, Volume 30, 553 - 561.

Kadefors, A. | 2005

"Fairness in interorganizational project relations: norms and

strategies"

Construction Management and Economics. Volume 23, 871-878.

Kaplan, B. | 1995

"Transaction Costs vs Agency Theory"

University of California.

Kashiwagi, D. Byfield, R. | 2002

"Selecting the best contractor to get performance: On time, on budget, meeting quality expectations."

Facilities Management, 1.2, 103-16. 


\section{Kashiwagi, D. Mayo, R. | 2001}

"Procurement of construction in the 21st century"

Canadian Society for Civil Engineering (CSCE).

\section{Kashiwagi, D. Mayo, R. | 2001}

"Best Value Procurement in Construction using Artificial Intelligence"

Construction Procurement. Volume 7, 42-59.

Kashiwagi, D. | 2004

"Best Value Procurement."

PBSRG, Arizona State University.

Kashiwagi, D. | 2004

"Six Sigma Applications in Construction."

Asc International Proceedings of the 4oth Annual Conference, Provo,

UT, CD Track CE. 41.

Kashiwagi, D. Parmar, Savicky, J. | 2004

"Traditional Low Bid procurement system versus PiPs in Construction Industry"

Association of Researchers in Construction Management, 1, 703-9.

Kashiwagi, D. et al. | 2005

"Is Performance Based Procurement A solution to Construction

Performance?"

published in 11th Joint Symposium: Combining Forecs -Advancing

Facilities Management and Construction through Innovation, Helsinki,

Finland, 172-182.

Kim, J. Mahomey J. | 2005

"Property Rights Theory, Transaction Costs Theory, and Agency Theory: An Organizational Economics Approach to Strategic Management." Managerial and Decision Economics, 26, 223-42.

Korczynski, M. | 1996

"Trust, Power and the Market: The Economic Sociology of Inter-Firm Relations"

Australian Graduate School of Management Working Paper, No. 61.
Kras, D. Bennema, S. $\mid 2005$

"Dossier goed opdrachtgeverschap; zoektocht naar alternatieven voor aanbesteden"

Building Business, februari 2005

Lai, L. Ng, F. Yung, P. $\mid 2008$

"The Coase theorem and a Coasian construction economics and management research agenda"

Construction Management and Economics, 26, 29- 46

Latham, M. | 1994

"The Latham Report: constructing the team"

Blackwell Science

Laverman, W. $\mid 2003$

"Model voor verbetering ligt klaar. Hoe nu verder?"

Building Business, September 2003

Lau, E. Rowlinson, S. $\mid 2005$

"The Value Base of Trust for the Construction Industry"

Construction Procurement, 11 (1) 19 - 39 .

Lee, E. Ha, S. Kim, S. | 2001

"Supplier selection and managementsystem considering relationships

in supply chain management"

Transactions on Engineering Management, 48:3, 307 - 318

Ling, F. Kumaraswamy, M. 2005

"The role of trust in team integration: a survey of contractors,

consultants and clients in Singapore"

Construction Procurement. Volume 11, 55 - 70.

Lorenz, E. | 1963A

"Deterministic nonperiodic flow"

Journal of the Atmospheric Sciences, 20 (2), 130 - 141. 
Lorenz, E. | 1963B

"The mechanics of vacillation"

Journal of the Atmospheric Sciences, 20 (2), 448 - 464.

\section{Love , P. Skitmore, M. Earl, G. | 1998}

"Selecting a suitable procurement method for a building project"

Construction Management and Economics. 16, 221 - 233

Luiten, B. Koolwijk, J. Ang, G. 2004

"Traditionele wijze van aanbesteden roep bouwfraude op"

Building Business, november 2004

Luo, Y. $\mid 2002$

"Contract, cooperation, and performance in international joint ventures"

Strategic Management Journal, Volume 23, 903 - 919.

Menard $\mid 2005$

"Handbook of New Institutional Economics"

Springer, Dordrecht.

\section{Molier, E. Noorderhaven, N. | 2004}

"Cultuurverandering in de bouw: razend moeilijk maar hard nodig" Building Business, februari 2004

Naoum, S. Mustapha, F. | 1995

"Relationship between the building team, procurement methods and project performance"

Construction Procurement. 50-63.

Nooteboom, B. | 1992

"Networks and transactions; do they connect?"

Paper of the annual conference of the Association of Post Keynesian

Studies, Rotterdam.
Palaneeswaran, E. Kumaraswamy, M. Ng, T. | 2003

"Targeting optimum value in public sector projects through 'best value'-focused contractor selection"

Engineering, construction and architectural management. Volume 10 $418-431$

Parmigiani, A. $\mid 2007$

"Why do firms both make and buy? An investigation of concurrent sourcing

Strategic Management Journal, 28: 285-311.

Pietroforte, R. | 1997

"Building international construction alliances: successful partnering for construction firms"

Spon, London.

\section{Pijnacker Hordijk, E.H. et al. | 2004}

"Aanbestedingsrecht; handboek van het Europese en het Nederlandse aanbestedingsrecht"

Sdu, Den Haag.

Pries, F. Dorée, A, Van der Veen, B. | 2003

"Het Bouwparadigma: waarom de bouw niet verandert" Building Business, februari 2003.

Pries, F Keizer, M. | 2006

"Gunnen op prijs en kwaliteit"

Building business, oktober 2006.

Pries, F. Keizer, P. Kuypers, Mooiman, M. | 2006

"Haal het beste uit de bouw"

[Getting the best out of construction]. SBR.

Pries, F. Kuypers, P. | 2006

"Innovatief aanbesteden: de kunst van het samenwerken"

Building Business, 2006 
Pries, F. Reeuwijk, van T. $\mid 2007$

"Gunnen op waarde; hoe doe je dat?"

[Value based awarding; how it can work]. PSiBouw (O2ob).

\section{Pries, F. de Ridder, H. | 2004}

"Kiezen opdrachtgevers de juiste bouworganisatievorm?"

Building Business, november 2004

Pries, F. de Ridder, H. | 2005

"Innovatief aanbesteden; doen we het nu niet goed dan?"

$h t t p: / / w w w . b u s i n e s s i s s u e s . n l /$ bouwportal/?ContentID $=b p 092$ viewed

februari 10, 2010

PWC $\mid 2002$

"De aanbestedingspraktijk van de Rijksoverheid 1996 - 2001"

Rahman, M. Kumaraswamy, M. | 2002

"Joint risk management through transactionally efficient relational contracting"

Construction Management and Economics. Volume 20, 45-54

Ramstad, Y. | 1996

"Is a Transaction a Transaction"

Journal of Economic Issues. Volume 30.

\section{Regieraad Bouw | 2003}

"Toekomstperspectief bouwsector"

www.regieraadbouw.nl/upload/documents/publicaties/toekomstperspectief\%2ovoor\%2ode\%2obouw.pdf viewed may 32006.

Regieraad Bouw | 2005, 2006 \& 2007

"Opdrachtgevers aan het woord"

(Clients speaking). ЕІв.

\section{Regieraad Bouw $\mid 2005$}

"Aanbestedingsregels moeten innovatie in de bouw stimuleren".
Regieraad Bouw | 2005

"Fundamenten voor vernieuwing"

Reve, T. Levitt, R. | 1984

"Organisation and Governance in construction"

Project Management, Vol. 2, 17-25.

Rijt, van der J. Hompes, M. Santema, S. | 2009

"The Dutch Construction Industry: An overview and its use of

performance information"

Journal of the Advancement of Performance Information \& Value (waiting to be published).

Rowlinson, S. | 1999

"Selection criteria" \& "Procurement Systems: A Guide to Best

Practice in Construction"

E\&FN Spon, London, $276-299$.

Saari, A. $\mid 2007$

"Flexibuild: a systematic flexibility management procdure for

building projects"

Facilities, Volume $25104-114$.

Scheltema, M. 2005

"Richtlijnen overheidsaanbestedingen moeten sterker gericht worden op stimuleren van innovatie"

Building Business, december 2005.

Schipper, de J. | 2007

"Geintegreerde contracten en het verwachtingspatroon van de

opdrachtgever"

Recht.nl. Gepubliceerd in Bouw nr. 10 852- 864

Schippers, A. Broekhuizen, E. $\mid 2006$

"Levenscyclusmanagement central in professionalisering bouwsector" Building Business, oktober 2006. 
Scott, R. $\mid 2001$

"Partnering in Europe: Incentive based alliancing for projects". Thomas Telford, London.

\section{Seo, Y. Hyan, C. | 2004}

"Procurement system selection model reflecting past performance"

Construction Procurement. Volume 10, 163-177

Sexton, M. Barrett, P. $\mid 2005$

"Performance based building and innovation: balancing client and industry needs"

Building Research and Information, 33: 142 - 148

\section{Shannon, C.E. | 1948}

"A Mathematical Theory of Communication"

The Bell System Technical Journal, Volume 27, 379 - 423.

Simon, H. | 1945

"Administrative Behavior"

New York, Free Press

\section{Simon, H. $\mid 1976$}

"A Formal Theory of the Employment Relationship"

Econometrica Volume 19, 293 - 305

\section{Sijpersma, R. | 2007}

"Op weg naar professioneel opdrachtgeverschap"

Building Business, april 2007.

Singh, A. $\mid 2002$

"Behavioural perceptions of design and construction engineers"

Engineering Construction \& Architectural Management 9(2): 66-80.

Speklé, R. | 2001

"Beyond generics; a closer look at hybrid and hierarchical governance" $\mathrm{PhD}$ thesis, Erasmus University, Rotterdam.
Stip, G. | 1995

"Transactiekosten theorie toepasbaar?"

Thesis, VU University, Amsterdam.

\section{Stomp, T. | 2004}

"Nu het aanbestedingsbeleid nog uit de schaduw"

Bestuurskunde, jaargang 13 nummer 8.

Sullivan, K. et al. | 2006

"Increasing performance by minimizing the passing of information"

Arcom conference proceedings, Association of Researchers in

Construction Management, 103 - 112

Takim, R. Akintoye, A. | 2002

"Performance Indicators for successful construction management projects."

Association of Researchers in Construction Management, 2, 545-55.

Thamhain, H. Wilemon, D. | 1987

"Building High Performing Engineering ProjectTeams"

Engineering Management (EM-34:3), 130-137.

Turner, J. | 2004

"Farsighted project contract management: incomplete in its entirety"

Construction Management and Economics. Volume 22, 75 - 83.

Turner, J. Müller, R. | 2003

"On the nature of projects as temporary organizations".

Project Management. Volume 21.

\section{Valkenburg, van M. et al 2008}

"Early contractor involvement: anew strategy for 'buying the best' in infrastructure development in the Netherlands"

IPPC 2008, conference proceedings. 
Waara, F. $\mid 2008$

"Mitigating Contractual hazards in public procurement: a study of Swedish local authorities"

Construction Management and Economics. Volume 26, 137 - 145

Ward, S. Curtis, B. Chapman, C. $\mid 1991$

"Objectives and performance in construction projects"

Construction Management and Economics. Volume 9, 343-353.

Weber, C. $\mid 1991$

"Vendor selection criteria and methods."

Operational Research, 50,(2-18.

Weele, van A. | 2001

"Inkoop in strategisch perspectief". Kluwer.

Williamson, O. | 1975

"Markets and Hierarchies: Analysis and Antitrust implications"

The Free Press, New York.

Williamson O. $\mid 1979$

"Transaction cost economics: the governance of contractual

relations."

Law \& Economics, $22.2: 233\urcorner-61$

Williamson, O. $\mid 1985$

"The economic institution of capitalism: Firms, Markets, Relational contracting"

New York, Free Press.

Williamson, O. $\mid 2007$

"Transaction Cost Economics: an introduction"

Sourced June 28, 2007

www.economicse-journal.org/economics/discussionpapers.
Winch, G. $\mid 1998$

"Zephyrs of creative destruction: understanding the management of innovation in construction"

Building Research and Information Volume 26, 268 - 279.

Wood, G. McDermott, P. | 1999

"Searching for Trust in the UK Construction Industry: An Interim View" СІв w92 Procurement Systems Conference, Thailand.

Yates, D. Hardcastle, C. | 2003

"The Causes of Conflict and Disputes in the Hong Kong Construction Industry. A Transaction Cost Economics Perspective."

RICs Foundation Research Papers, Volume 4, Number 22.

Yin, R.K. $\mid 2008$

"Case Study Research: Design and Methods"

Thousand Oaks, Sage Publications.

Zhang, Z. et al. 2003

"Evolution of supplier selection criteria and methods"

Hong Kong Polytechnic University

http://www.globelics-bejing.cn/paper/Zhi ming\%2o viewed on

December 11, 2006.

Overige bronnen ten aanzien van methodologie, statistiek en aanbesteden in het algemeen

Baarda D.B. de Goede M.P.M. | 2007

"Basisboek statistiek met sPss"

Wolters Noordhoff, Groningen.

Berger, M.P.F. Imbos, Tj. And Janssen, M.P.E. $\mid 2000$

"Methodologie en statistiek"

Universiteit Maastricht. 
Bersselaar, van den V. $\mid 1995$

"Discursieve vaardigheden; leidraad voor probleem analyse,

argumentatie en onderzoek"

Coutinho, Bussum.

Bühl, A. 2010

"SPSS 8, einführung in die modern Datenanlyse"

Pearson Studium, München.

Field, A. 2009

"Discovering statistics using SPSS"

Sage, London.

Heus, de P, Leeden, van der R. and Gazendam, B. | 2003

"Toegepaste Data analyse"

Reed Business Information.

Horst, van der H. and Schenk, M.A. | 2008

"Aanbesteden!? Praktisch handboek voor overheden en nutsbedrijven" sDu, Den Haag.

Koning, de H. Sproncken, W. | 2001

"Contractering bij Bouwprojecten; over het contracteringsproces,

organisatie- en contractmodellen en aanbestedingen"

Elsevier Bedrijfsinformatie.

Maso, I. Smaling, A. | 1998

"Kwalitatief onderzoek: praktijk en theorie"

Boom, Amsterdam.

Verschuren, P. Doorewaard, H. | 2007

"Het ontwerpen van een onderzoek"

VNO/NCW 2005

"Overheidsopdrachten? Vergeet het maar!; Onderzoek naar praktijkervaringen met overheidsopdrachten" bijlagen

Bijlage I

Manco's van traditioneel aanbesteden

Deze bijlage gaat in op het traditionele aanbesteden in de bouw. Daarbij bereidt een opdrachtgever (eventueel ondersteund door adviseurs) een project tot en met bestek en tekeningen voor en zet het dan 'in de markt' (Goovaerts \& Pries, 2004; Kras \& Bennema, 2005). Zo hoopt de opdrachtgever de partij te selecteren die het werk tegen de beste condities (vaak de laagste prijs!) kan realiseren. Zoals verderop zal blijken (en ook in hoofdstuk een is beschreven) kleven er voor veel hedendaagse bouwprojecten een aantal manco's aan deze werkwijze. Deze bijlage geeft inzicht in hoe internationale auteurs van wetenschappelijke bronnen aankijken tegen traditioneel aanbesteden. Daaruit blijkt dat er sprake is van een correlatie tussen gunnen op prijs en low performance (Butler, 2002, Dorée, 2004). In het bijzonder wordt in gegaan op het gebrek aan ruimte voor inschrijvers om hun vakmanschap en knowhow in een vroeg stadium in te kunnen brengen, de focus op de laagste prijs en wat dat impliceert, de versnippering in de bouwkolom die samenwerking bemoeilijkt, het gebrek aan vertrouwen in de traditionele setting en de hoge transactiekosten die het gevolg zijn van dat gebrek aan vertrouwen.

Traditioneel (en op laagste prijs) aanbesteden nader verkend Het aanbesteden van een bouwwerk is te vergelijken met het kopen op basis van een belofte; de opdrachtgever moet immers nog maar zien of de bouwopgave ook conform afspraken gerealiseerd zal worden (Dorée, 2001). Opdrachtgevers zoeken dus houvast en denken die te 
vinden door het bewandelen van gebaande paden (Pries et al, 2006; Dorée \& Boes, 2007). Ook adviseurs zijn veelal geschoold in, en ervaren met, de bekende traditionele aanpak. Deze traditionele aanpak kan goed werken voor eenvoudige, goed te specificeren en niet te grote projecten waarvoor voldoende aanbieders in de markt aanwezig zijn, maar voor projecten met een grotere complexiteit die nieuwe uitdagingen bevatten schiet deze benadering te kort (Ang, Groosman en Scholten, 2005). In diverse journal papers zijn kwalificerende beschrijvingen van het traditionele aanbesteden te vinden die deze tekortkomingen duiden. Latham (1994) en Egan (1998) karakteriseren bijvoorbeeld de UK Construction Industry als een industrie die gekenschetst wordt door budgetoverschrijdingen, vertragingen en een lage productiviteit die tevens "schreeuwt om betere samenwerking" (Dagenais, 2007). Ook Dorée (2001) somt een aantal karakteristieken op: fragmentatie, sub-optimalisaties, korte termijngerichtheid en opportunisme. Zoals blijkt uit de "Revaluing Construction" publicaties (o.a. Journal of Building Research \& Information) wordt er wereldwijd gezocht naar initiatieven om de prestaties van de bouwsector te verbeteren. Nederland staat dus niet alleen in de wens om actief beleid te voeren om te bereiken dat de bouwsector de laagste prijs oriëntatie verlaat voor een oriëntatie op waarde, waardoor de opdrachtgever meer value for money bereikt en de opdrachtnemer een 'gezonde' marge kan maken. Vele landen willen bereiken dat de sector beter inspeelt op de behoeften van de opdrachtgever (de Stichting Klantgericht Bouwen heeft onderzocht dat opdrachtgevers de klantgerichtheid van de bouw in 2004 met een 6 ,o beoordeelden; in 2008 is dat gedaald tot een 5,7 ) en beter samenwerkt in plaats van dat de conflictcultuur de boventoon voert. Om versnippering tegen te gaan (Saari, 2007), overschrijdingen van budgetten en planningen terug te dringen, een veiliger en gezonder werkplek te creëren en ruimte te maken voor innovatie en professionalisering. Ook het in opdracht van PSiBouw uitgevoerde internationale onderzoek met de titel "Inventory of international reforms in building and construction" (2004) onderschrijft noodzaak en belang van veranderingen in de bouwsector. De belangrijkste aanleidingen voor verandering zijn volgens dit rapport de in vergelijking met andere sectoren matige productiviteit en achterblijvende innovatie. Ook de faalkosten die volgens dit rapport tussen de 12 en $15 \%$ van de omzet bedragen, zijn vergeleken met andere sectoren opvallend hoog. Daarnaast beschrijft dit rapport een aantal tekortkomingen (zoals ook opgetekend tijden de parlementaire enquête) die bijdragen aan gebrekkige performance.

Zo belemmeren de traditionele marktstructuren en de (per project) kortlopende relaties, het optimaliseren van samenwerking, het bereiken van balans tussen kwaliteits- en prijsfocus en het bewust doormaken van voldoende steile leercurves. Zowel bij opdrachtgevers als bij opdrachtnemers. De traditionele benadering bevordert de focus op de initiële kosten, maar belemmert de focus op levensduurkosten en

beheers- en exploitatievraagstukken. Dorée (2001) stelt dat doordat bouwers in de traditionele aanpak alleen verantwoordelijk zijn tot en met de oplevering van het bouwwerk, het inzetten van inferieure

materialen en oplossingen nogal eens gebezigd wordt om tot een beter rendement te komen. Beheers- en onderhoudsproblemen die daarvan het gevolg zijn, komen letterlijk voor rekening van een ander. Volgen het "Inventory of international reforms in building and construction" rapport moeten oplossingen voor de hiervoor beschreven problematiek gevonden worden door 'anders werken' economisch aantrekkelijk te maken. Een dominantere rol voor EMVI, met een behoorlijk relatief gewicht voor de kwalitatieve aspecten, kan daartoe een krachtige impuls vormen. Verder beschrijft dit rapport dat als goede prestaties uit het verleden de kans op toekomstig werk verhogen, daarvan een heilzame werking uit zal gaan (het 'reputatiemechanisme'; zie ook hoofdstuk drie).

Fernie, Leiringer en Thorpe (2006) refereren in hun artikel "Change in construction: a critical perspective" aan een onderzoek van Murray \& Langford dat diverse onderzoeken over een tijdspanne van 60 jaar beschrijft. Algemene conclusie daaruit is dat de sector is doordrongen van behoefte aan meer integratie, teamwork, vertrouwen, partnerschap, standaardisatie en value for money. 


\section{Samenvattend:}

Deze nadere verkenning van traditioneel aanbesteden in de Bouw levert het algemene beeld op dat de (traditionele) werkwijze niet volstaat voor hedendaagse veelal complexe projecten. De slechte samenwerking, versnippering, suboptimalisatie, hoge faalkosten en regelmatige overschrijdingen van planningen en budgetten, zijn duidelijke manifestaties van de manco's van het traditionele aanbesteden. Het moet dus anders zoals door Guccio treffend wordt samengevat:

“...Aanbestedingen moeten er dus op gericht zijn competitie te bevorderen en tegelijketijd value for money te bereiken (Guccio, 2008").

Na deze algemene beeldvorming zoals door internationale literatuur geschetst, wordt wat uitgebreider stilgestaan bij een aantal karakteristieken van traditioneel aanbesteden en de nadelen die daaraan kleven. Beschreven wordt wat er in de sector leeft rondom traditioneel aanbesteden.

Weinig ruimte voor inbreng knowhow van inschrijvers

Bij de traditionele aanpak wordt onder verantwoordelijkheid van de opdrachtgever (en dus eveneens voor zijn risico!) het aan te besteden project ontworpen en technisch uitgewerkt in een bestek en bijbehorende bestektekeningen (Goovaerts \& Pries, 2006). Daarmee worden materialisering, dimensionering, detaillering, verwerkingswijzen en voorschriften vastgesteld en vastgelegd. Bij de aanbesteding hoeven inschrijvers in principe alleen hoeveelheden en prijzen per eenheid te bepalen om zo tot een inschrijfsom te komen. Daarmee wordt de

${ }^{100}$ Alleen als varianten toegestaan zijn kunnen inschrijvers eigen inbreng

hebben. speelruimte voor inschrijvers beperkt ${ }^{100}$. Er is voor hen geen ruimte om hun (meest recente) ervaringen en knowhow in te brengen. In bestekken worden normen en standaarden aangegeven. Voor de opdrachtgever beschrijven deze normen en standaarden een zeker minimum kwaliteitsniveau. Inschrijvers echter, zien diezelfde normen en standaards als een soort van maximum; ze prijzen zich immers uit de markt (er wordt bij een traditionele aanbesteding nagenoeg altijd gegund op basis van laagste prijs) wanneer ze boven deze minimale drempels calculeren en werken. Zo gaat optimalisatiepotentieel verloren en wordt innovatie geremd (Egan, 1998; Sexton \& Barrett, 2005). Caerteling et al (2008) memoreert in dit kader dat de meest vergaande verandering die naar

aanleiding van Egan wordt doorgevoerd, het besef is dat de strikte scheiding tussen ontwerpen en bouwen moet worden losgelaten en da een meer integratieve benadering meer is gewenst. Bouwers zouden al tijdens de ontwerpfase bij het project betrokken moeten worden. Z verwachten daarmee kosten te reduceren, kwaliteit te verbeteren en innovatie te bevorderen (Caerteling et al, 2008).

Functioneel specificeren (ook wel oplossingvrij specificeren genoemd; de opdrachtgever formuleert namelijk zijn vraag, maar laat het antwoord daarop -de oplossing- door de markt aandragen) biedt volgens het rapport "Aanbestedingsregels moeten innovatie in de bouw stimuleren" van de Regieraad Bouw (september 2005) perspectief. Aanbieders worden hierdoor 'uitgelokt' een optimale oplossing te bedenken (Laverman, 2003; Scheltema, 2005; Regieraad Bouw, 2005). Functioneel specificeren vergt volgens dit rapport aanpassing van de werkwijzen van zowel de aanbestedende diensten als van aannemers (overigens geldt hetzelfde voor de verhoudingen tussen aannemers en onderaannemers). Opdrachtgevers kunnen door middel van het hanteren van oplossingsvrije specificaties veranderingen in de sector uitlokken. De regelgeving en het beleid van de opdrachtgever zouden daartoe functioneel specificeren moeten bevorderen (Egan, 1998).

\section{Samenvattend:}

Bij de traditionele aanpak hebben uitvoerende partijen tijdens ontwerp en engineering weinig inbreng. Ze kunnen tijdens de aanbesteding alleen afprijzen wat anderen hebben bedacht. Daarmee gaat innovatiepotentieel verloren en wordt voorbij gegaan aan de inbreng vanuit het praktijkperspectief. Uitvoerende partijen die in de gelegenheid gesteld worden om vroeg in het wordingsproces mee te kunnen denken, kunnen recente ervaringen en knowhow inbrengen. Dat kan de maakbaarheid van het project ten goede komen, de totale doorlooptijd verkorten en tot financiële voordelen leiden. Maar ook bijdragen aan een project dat tijdens de exploitatiefase meer gebruikswaarde/gemak en minder kosten voor beheer en onderhoud oplevert.

Focus op laagste prijs; de goedkoopste in plaats van de beste oplossing De Regieraad Bouw heeft in haar eerste actieplan (mei 2004) het pijnpunt van de laagste prijs oriëntatie tot een speerpunt gemaakt. Het ontbreken van prikkels tot vernieuwing en te weinig aandacht voor het 
${ }^{101}$ De verwachting is dat het duurzaamheidsdenken dat in toenemende mate onderdeel wordt van inkoop en aanbestedingsbeleid (zie bijvoorbeeld duur-

zaamheidstargets en criteria zoals over-

heidsopdrachtgevers die met elkaar afgesproken hebben) een impuls zal geven aan de verschuiving van 'laagste prijs' naar EMVI. leveren van voldoende kwaliteit vormen daarvoor de belangrijkste argumenten (Regieraad Bouw, 2004). Traditioneel aanbesteden gaa doorgaans gepaard met gunning op laagste prijs (Luiten, Koolwijk \& Ang, 2004). Alleen het prijsniveau telt dus mee als het gaat om onderscheidend vermogen. Een volledig 'dichtgetimmerd bestek' waarin de opdrachtgever beschrijft wat minimaal gerealiseerd moet worden in combinatie met de selectie van een partij die het werk moet/mag maken op basis van het laagste prijscriterium, is karakteristiek voor de traditionele aanpak (Pries, Dorée en van der Veen, 2003). Opportunistisch gedrag wordt door deze werkwijze als het ware uitgelokt (zie hoofdstuk een en drie). Ook Dorée beschrijft in zijn proefschrift ("Gemeentelijk Aanbesteden", 1996) de onvrede over het functioneren van de bedrijfstak, gerelateerd aan de laagste prijs focus. Hij beschrijft dat de laagste prijs focus ertoe bijdraagt dat behartiging van eigenbelangen voorop staat (ieder voor zich). Daardoor groeien achterdoch en wantrouwen. Dat bemoeilijkt innovatie; innovatie loont immers niet. Dorée geeft tevens aan dat het doorbreken van deze patronen alleen succesvol opgepakt kan worden in gezamenlijkheid (opdrachtgevers met opdrachtnemers). Aannemers voelen zich bij de laagste prijs focus bovendien niet getriggerd om hun beste staf in te zetten (zou immers tot een hogere en daarmee minder concurrerende prijs leiden, en dat is het enige dat telt), zoeken gaandeweg naar mogelijkheden om meerwerk te kunnen declareren en er is tijdens de uitvoering veel controle en inspectie nodig om te bewerkstelligen dat daadwerkelijk conform bestek gewerkt wordt.

Ook in het EІв onderzoek "Opdrachtgevers aan het woord 2006" is nog steeds voor $92 \%$ van de opdrachtgevers prijs het belangrijkste gunningscriterium. Ook in de 2007 versie is prijs nog steeds het belangrijkste criterium, hoewel een verschuiving ten gunste van geïntegreerde contracten, life cycle costs en kwaliteitsdenken gaande is. Ook worden criteria als samenwerkingsbereidheid en -vermogen, duurzaamheid ${ }^{101}$ en innovatiegerichtheid vaker benut. In de praktijk leidt het hanteren van het laagste prijscriterium tot risico's en ongewenste effecten als 'onder de prijs duiken' om werk binnen te halen waarna na gunning wordt geprobeerd toch tot een (redelijke) marge te komen (Alders, 2002; Greenood \& Yates, 2006; Dorée \& Boes, 2007; Waara, 2008). Desnoods ten koste van de belangen van de opdrachtgever. Dit laatste verschijnsel treedt ook op wanneer er sprake is van de zogenaamde winner's curse; de inschrijver aan wie het werk is gegund blijkt in dit geval het werk te hebben onderschat. Om dan toch tot een zeker rendement te geraken zal de neiging tot opportunistisch gedrag niet gering zijn. Daarnaast zijn na gunning vaak aanpassingen nodig waarover onderhandeld moet worden. Uit onderzoek van Bajari, Houghton en Tadelis (2006) blijkt dat deze onderhandelingen in een situatie waarin vóór gunning hard op laagste prijs is gestuurd tot relatief gezien hogere kosten leiden dan in een situatie waarin gegund is op basis van EMVI. Ook Waara (2008) toont aan dat gunnen aan de laagste bieder vaak leidt tot budgetoverschrijdingen en matige kwaliteit. Hij refereert daarbij aan eerder onderzoek (Holt et al, 1995; Gransberg \& Ellicott, 1997; Hatush \&

Skitmore, 1997; Kashiwagi \& Byfield, 2002; Palaneeswaran et al, 2003) dat tot gelijke inzichten heeft geleid van.

Overigens zien we dat aan hoofdaannemers regelmatig een aantal eisen wordt gesteld op het gebied van ervaring, kwaliteitsmanagement en dergelijke. Vervolgens worden die eisen de facto omzeild doordat subcontractors (en die doen een al maar groeiend deel van het uitvoerende werk) enkel op laagste prijs geselecteerd worden. Dainty, Briscoe \& Millet (2001) stellen dat de relaties tussen hoofdaannemer, onderaannemers en leveranciers vaak iets van vijandigheid in zich hebben. Deze 'vijandigheid' is vaak terug te voeren op het 'uitknijpen' van onderaannemers en leveranciers om zelf toch tot een bepaald rendement te geraken. Ook dit fenomeen is voor een groot deel weer terug te voeren op het door opdrachtgevers hanteren van het gunningscriterium 'laagste prijs' (Dainty, Briscoe \& Millet, 2001)

In het rapport "Professioneel opdrachtgeverschap en Vakmanschap, 2007" betogen Dorée en Boes dat het hanteren van het prijscriterium gevoed is door politieke druk tijdens het post-bouwfraude tijdperk. De nadruk lag immers op transparantie, objectiviteit, integriteit en zorgvuldigheid. Dat maakt het toepassen van andere criteria (die doorgaans om een subjectief oordeel vragen in plaats van een objectieve meting zoals bij het prijscriterium mogelijk is) lastiger. Tegelijkertijd wordt ook in dit rapport geconstateerd dat het hanteren van het laagste prijscriterium diverse problemen oplevert zoals standaard meerwerk ten gevolge van onvolkomenheden/wijzigingen in het bestek, gecombineerd met opportunistisch gedrag van de opdrachtnemer. Ook Ward, 
Curtis \& Chapman (1991) verwoorden het manco van de laagste prijsoriëntatie. Ze stellen dat de partij die de aanbesteding wint, nogal eens die partij is die de complexiteit van het werk het meest heeft onderschat, of de meeste vergissingen/fouten heeft gemaakt bij zijn prijsvorming. Eenmaal 'onderweg' gaat deze partij zoeken naar mogelijkheden om toch renderend te kunnen zijn; het fenomeen van de winner's curse zoals hiervoor al genoemd is in dit kader een bekend verschijnsel (Grosskopf, Bereby en Bazerman, 2003)

In verschillende onderzoeken (Weber, 1991, Zhang et al, 2003, Jonkhoff, 2006, Dreschler, 2008) wordt aangetoond dat aanbesteden op waarde in plaats van op laagste prijs van grote importantie is voor opdrachtnemer en opdrachtgever. Voor de opdrachtnemer is winst het verschil tussen bouwkosten en de prijs van het bouwwerk. Een hogere waarde biedt dus perspectief op meer marge ("Naar een waardevolle aanbesteding" building Business oktober 2006,). Jonkhoff stelt in datzelfde artikel dat voor grote en complexe projecten aanbesteden op prijs én waarde zichzelf terugverdient. Molier en Noorderhaven stellen dat gunning op laagste prijs de huidige bouwcultuur (onder andere gekenmerkt door gebrek aan vertrouwen, defensieve opstelling, behoudende conservatieve houding) voedt (Molier en Noorderhaven, 2004).

Michiel Scheltema (ministerie van Justitie en verantwoordelijk voor het rapport "Juridisch kader aanbestedingen", tevens voorzitter van de commissie die de Leidraad Aanbesteden voor de Bouw heeft voortgebracht) stelt dat concurrentie tussen marktpartijen zich moet afspelen rond een optimale verhouding tussen prijs en kwaliteit. Deze concurrentie moet niet alleen gebaseerd zijn op de initieel laagste prijs (Regieraad Bouw, "Fundamenten voor vernieuwing" 2005, Arko,).

\section{Samenvattend:}

Traditioneel aanbesteden wordt gekarakteriseerd door een focus op de laagste prijs. Deze zogenoemde 'laagste-prijs-klem' kent echter een aantal ongewenste nevenefecten. Kwaliteit van aanbieders en aanbiedingen levert bij deze aanpak namelijk uiteindelijk geen onderscheidend vermogen op. Dat onderscheidende vermogen wordt alleen bepaald door de laagste prijs. Dat stimuleert mechanismen die bedreigend zijn voor een gecontroleerd (bouw)proces en eindresultaat van dat proces. Focus op laagste prijs bevordert de neiging tot opportunistisch gedrag. Daarom is het van groot belang om bij projecten die een zekere complexiteit en kwalitatieve uitdaging bevatten de 'laagste-prijs-klem' in te ruilen voor 'gunnen op waarde'.
Strikte scheiding tussen disciplines, faseringen en versnippering Bij de traditionele aanpak starten bouwkundig aannemers, installateurs en overige onderaannemers als het ontwerp klaar is en uitgewerkt is op bestekniveau. Met andere woorden: alleen de eerste partij ${ }^{102}$ in he totstandkomingsproces creëert waarde. Spelers daarna zijn in de rege niet in de positie waarde toe te voegen ${ }^{103}$. Daarmee blifft veel potentiee onbenut. Haselhoff en Rijlaarsdam publiceerden in 1988 "Het kan best anders in de bouw" (Stichting Bouwresearch, publicatie no. 166). Ze hanteren in dit artikel een veelzeggende metafoor van een estafetteloop van een Nationaal Team dat elkaar bij de start niet echt goed kent, met als gevolg dat de wisselingen kostbare tijd vragen en er veelvuldig naa zondebokken wordt gezocht als de laatste loper het tijdverlies niet heeft weten goed te maken.

Bouwen wordt wel eens omschreven als het in één keer goed, met verschillende gelegenheidspartners, in weer en wind, produceren va een prototype (Dorée, 2001. Behalve de versnippering valt in deze karikatuur ook op dat een gebouw als prototype gezien kan worden dat er onder sterk wisselende atmosferische invloeden en omstandigheden gewerkt wordt, hetgeen de nodige impact kan hebben, en dat dit prototype meteen goed moet zijn. In vergelijking met bijvoorbeeld de automotive sector waar feitelijke productie pas start nadat prototyping resultaten tevredenstellend zijn, in geconditioneerde omstandigheden wordt gewerkt met enkele co-makers die al vroeg tijdens het R\&D proces participeerden, lijkt dit (in eenmaal goed, binnen planning en budget) in de bouw een bijna onmogelijke opgave.

Graham Winch (1998) beschrijft dat innovatie in complexe omgevingen als de bouw (waar geen sprake is van massaproductie, veel actoren, specialisaties, veel regelgeving) disproportioneel is gericht op product/ technische innovaties, waardoor procesinnovatie achter blijft. Hij pleit dan ook voor meer aandacht voor procesmatige vernieuwing en een meer geïntegreerde benadering ervan. Dit is belangrijk want gebouwen en bouwwerken zijn nu eenmaal (uitzonderingen daar gelaten) uniek, locatiegebonden en niet op voorraad te produceren (Dorée, 2001). Dat vraagt dus om een benadering die samenwerking bevordert, om een sector die de knowhow van alle partners slim gebruikt. Het traditionele aanbesteden met zijn strikte scheiding tussen ontwerpen en bouwen staat hiermee op gespannen voet. De bouw is versnipperd georganiseerd
${ }^{102}$ Naast de architect geldt dit ook voor de onder de verantwoordelijkheid van de opdrachtgever ingeschakelde

overige adviseurs.

${ }^{103}$ In de praktijk verloopt dit minder extreem dan hier beschreven. Aannemers maken economische afwegingen tussen materiaal en verwerkingskosten. Deze afwegingen kunnen leiden tot toepassing van duurdere materialen die daarentegen verwerkingsvoordelen opleveren of tijdens garantieperioden tot geringere aanspraken leiden. Daarnaast worden varianten soms toegestaan. Ook in die situaties zijn aannemers in de gelegenheid 'waarde toe te voegen'. 
is, terwijl dankzij de toegenomen complexiteit de behoefte aan integrale benadering juist is toegenomen (Naoum \& Mustapha, 1995; Pries \& de Ridder, 2005; de Schipper, 2007).

Valkenburg et al (IPPC 2008) beschrijft dat vroeger betrekken van aannemers in het algemeen leidt tot meer innovatie (het ontwikkelen van optimalisatievoorstellen maakt deel uit van de competitie, het ontwikkelen van slimme voorstellen wordt daardoor bevorderd), meer value for money, besparing van tijd (parallelle processen in plaats van sequentiële) en betere projectbeheersing. Ook wordt de link tussen ontwerpen, bouwen en beheren versterkt. Bovendien leidt het vroeger betrekken tot meer in elkaars verlengde liggende belangen aan opdrachtgevers en opdrachtnemers zijde (zoals in hoofdstuk drie behandeld wordt draagt dat bij aan projectsucces). Egan (1998) refereert ook aan deze zaken; geïntegreerde processen (dus ook het vroeger betrekken van uitvoerende partijen) en teamwork (bevorderen van samenwerking) worden genoemd als key drivers for change in the industry.

Door de fasering en de vele specialisaties wordt met veel verschillende partijen samengewerkt. Daardoor ontstaan er vele interfaces en overdrachtsmomenten waarbij potentiële communicatieproblemen op de loer liggen. Deze fragmentatie leidt tot afstemmingsproblemen en impliceert de uitwisseling van veel data en informatie. Pries en de Ridder (2004) noemen in dit kader "vele matig georganiseerde overdrachtsmomenten". Turner (2004) beschrijft twee manieren om een projectorganisatie te definiëren. De eerste zoals het zou moeten zijn, de tweede zoals het meestal is:

nr 1 Een tijdelijke organisatie (Turner \& Müller, 2003) waarmee de opdrachtgever resources verzamelt en hen motiveert, in een coöperatieve sfeer hun doelstellingen te realiseren.

$n r 2$ Een markt waarin de opdrachtgever een prestatie koopt tegen de laagste prijs in een sfeer van conflicten met de aannemers, waarbij bij gunning sprake is van een winnaar en een verliezer.

Volgens Scott (2001) leidt deze tweede definitie tot tegengestelde belangen tussen opdrachtgever en opdrachtnemers die uiteindelijk bij oplevering vaak een loose-loose uitkomst heeft. Graham Winch (1998) benoemt de frictie waarmee de sector kampt; een aannemer omschrijft hij als een partij die continue capaciteit levert om de gebouwde omgeving te vormen, terwijl die gebouwde omgeving projectgewijs (en dus per definitie discontinu) tot stand komt.

Fragmentatie als gevolg van specialisatie heeft zich de afgelopen decennia nog verder ontwikkeld, met een toenemende behoefte aan integrale aansturing en benadering tot gevolg. Het economisch verantwoord realiseren van een project dat de gevraagde functionaliteiten biedt, kan immers alleen als alle puzzelstukjes samen in een keer het verwachte resultaat opleveren. Communicatie, afstemming, coördinatie, definiëren van demarcatielijnen en interfaces daaroverheen, raakvlakkenmanagement hebben hun intrede gedaan om te zorgen dat alle lijntjes op het juiste moment en op de juiste plaats bijeen komen (Brady, Davies, Gann, 2005)

Er is sprake van toenemende interesse voor samenwerkingsvormen in de bouw als reactie op escalerende conflicten en vijandige verhoudingen tussen opdrachtgevers en opdrachtnemers (Bresnen and Marshall, 2000; Chan et al, 2003). De toegenomen noodzaak tot verbetering van samenwerking komt ook voort uit toegenomen complexiteit en daarmee toegenomen onzekerheid. Dat vraagt om kennisdeling, samenwerking, flexibiliteit en integrale benadering van vraagstukken (Pietroforte, 1997; Rahman and Kumaraswamy, 2002). Wel moet er rekening mee gehouden worden dat ontwerpende en uitvoerende capaciteiten separaat zijn georganiseerd en ook maatschappelijk afzonderlijk zijn gepositioneerd en georganiseerd (Dorée, 2001)

\section{Samenvattend:}

Fragmentatie in de sector is voor een groot deel het gevolg van toenemende complexiteit van projecten en daarmee een direct en onvermijdelijk gevolg van specialisatie. Tegelijkertijd is er de noodzaak om de knowhow van de gehele keten te benutten om in één keer op een efficiënte wijze tot het beoogde eindresultaat te komen. Oplossingsvrij specificeren vormt een krachtig middel om de verschillende ketenpartners tot een integratieve benadering van de bouwopgave te stimuleren. Het bevordert vroegtijdige participatie en daarmee ook het begrip voor elkaars inbreng en belangen hetgeen kwaliteit van samenwerking bevordert. Betere samenwerking vergroot de kans op projectsucces. 


\section{Hoge transactiekosten}

De strikte scheiding tussen de fasen en de volgordelijkheid waarmee betrokkenen bij een project in beeld komen, in combinatie met de

hoeveelheid informatie die uitgewisseld moet worden naar veel verschillende actoren, doen de transactiekosten stijgen (Erikson, Pesamaa, 2007). Ook de eisen die opdrachtgevers stellen aan de door inschrijvers in te leveren documenten, dragen daaraan bij. De diametraal tegenover elkaar staande posities die opdrachtgever en opdrachtnemer tijdens de uitvoeringsfase ten opzichte van elkaar innemen (competitief in plaats van coöperatief gedrag), veroorzaken veel controle- en inspectieinspanningen aan de zijde van de opdrachtgever (Reve, Levitt, 1984). Bresnen \& Marshall (2000) stellen dat de confronterende posities die opdrachtgevers en opdrachtnemers tegenover elkaar innemen, geleid hebben tot inefficiënte bedrijfsvoering die de totale projectkosten opdrijven. Opdrachtnemer en opdrachtgever besteden beiden veel tijd aan dossiervorming in het kader van meer/minderwerk discussies en ten behoeve van bewijsvoering over het invullen, nakomen van wederzijdse plichten.

Graham Winch (1998) haalt Reve \& Levitt (1984) aan waaruit de problematiek van transactiekosten in traditioneel aanbestede en gemanagde projecten blijkt. Het gebrek aan vertrouwen heeft ertoe geleid dat er ver doorgevoerde systemen van controle zijn geïmplementeerd. Denk daarbij aan systemen en rapportages op het gebied van kwaliteitsmanagement, performance management, voortgangsbewaking. Dit alles heeft geleid tot een control opgave die als het ware een extra hiërarchische laag heeft opgeleverd, met alle (overhead) kosten van dien. Dit mechanisme wordt verder versterkt door de neiging informatie pas dan te delen als dat de eigen belangen op de eerste plaats dient.

\section{Samenvattend:}

De transactiekosten bij een traditionele aanpak zijn hoog. Dat heeft veel te maken met het vooraf volledig 'dicht willen timmeren' van het project en het contract in combinatie met de versnipperde aanpak. Na gunning is er veel controle nodig om naleving van het gecontracteerde af te dwingen. De 'laagste-prijs-klem' is hiervan een belangrijke oorzaak.

\section{Gebrek aan vertrouwen bedreigt projectsucces}

De traditionele aanpak met de tijdens de parlementaire enquête Bouw genoegzaam besproken symptomen, heeft geleid tot een situatie waarin opdrachtgever en opdrachtnemer elkaar maar matig vertrouwen. Dat is ook niet verwonderlijk als partijen samenwerken in een (traditioneel) construct dat, zoals we eerder zagen, de neiging tot opportunistisch gedrag bevordert. De Regieraad Bouw stelt in 2005 dat transparantie, een goede kwaliteit/prijs verhouding en innovatie de pijlers zijn voor professionalisering omdat deze zaken bijdragen aan vertrouwen tussen actoren. Graafland en Nijhof (2007) koppelen daar aan dat meer vertrouwen leidt tot meer openheid, waardoor er meer informatie gedeeld wordt wat de kwaliteit van beslissingen ten goede komt. Ook hogere efficiëncy, lagere transactiekosten en meer innovatie zien zij als resultante van een samenwerking waarin meer vertrouwen heerst.

Ook in internationale literatuur wordt vertrouwen gezien als een factor van belang. Bromiley \& Cummings (1995) stellen dat relaties die op vertrouwen zijn gebaseerd voordelen creëren als lagere kosten, betere performance en kortere doorlooptijden. Zij stellen dat vertrouwen vaak is opgevoerd als een sleutelbegrip in de hervorming van de internationale bouw. In het kader van dit onderzoek is het begrip 'vertrouwen' echter lastig te hanteren. Het betreft een zogenaamd contrafactisch

begrip: het aantonen van vertrouwen is bijna ondoenlijk, het ontbreken ervan des te makkelijker. Daarom worden in dit onderzoek de begrippen betrouwbaarheid of liever nog voorspelbaarheid gehanteerd. Het gaat er bij een aanbesteding immers om de voorspelbaarheid van het tijdens de uitvoering te verwachten gedrag en prestaties te vergroten. Immers, zoals eerder geconstateerd wijkt, bij de traditionele aanpak, tijdens de aanbesteding verwacht gedrag/prestaties en feitelijk gedrag/prestaties (na gunning) van aannemers regelmatig van elkaar af op een wijze die niet bijdraagt aan projectsucces (Barrett, 2007; Ang, 2004)

Dat de voorspelbaarheid bij traditioneel aanbesteden nog vaak te wensen over laat, blijkt uit het al eerder aangehaalde rapport van Dorée en Boes ("Professioneel opdrachtgeverschap en vakmanschap", 2007) waarin ze stellen dat traditioneel aanbesteden nog steeds geen adequaat antwoord heeft op het tegengaan van opportunistisch gedrag van opdrachtnemers om onvolkomenheden in het bestek ten eigen voordeel te benutten. Het opstellen van een waterdicht contract en bestek is bij een complex project 
bijna onmogelijk en onevenredig duur. Als contract en bestek dus onvolkomenheden bevatten, ben je als opdrachtgever in grote mate afhankelijk van de coöperatieve instelling van de opdrachtnemer. Ook Haselhoff en Rijlaarsdam onderkennen dat het concurrentieel gedrag niet ophoudt nadat de contracten zijn getekend. Ze stellen dat er veelal sprake is van een verkrampte samenwerking tussen partijen die primair hun eigen voordeel in het oog hebben.

Het EIB (Economisch Instituut Bouwnijverheid) onderzoek "Procesintegratie en innovatief ondernemerschap in de bouw" (Caniels en

Sijpersma, december 2005) besteedt uitgebreid aandacht aan het aspect betrouwbaarheid. 3800 bouwbedrijven zijn benaderd waarbij een viertal stellingen zijn voorgelegd met betrekking tot transparantie van en vertrouwen in opdrachtgevers. De meeste van die bedrijven (tussen de 60 en $80 \%$ ) vinden dat opdrachtgevers informatie voor hun opdrachtnemers achterhouden. Dit wordt bevestigd door het EIв onderzoek

"Opdrachtgevers aan het woord 2006" waarin het aantal bedrijven dat aangeeft dat opdrachtgevers informatie achterhouden is gestegen van $58 \%$ in 2005 naar $67 \%$ in 2006. In het EIB onderzoek "Opdrachtgevers aan het woord 2007" wordt juist een toename van het vertrouwen gesignaleerd. Opdrachtgevers ervaren een meer positieve opstelling bij het oplossen van problemen, grotere maatschappelijke betrokkenheid en zien meer innovatieve oplossingen van de zijde van opdrachtnemers. In het eerder aangehaalde artikel "Objectives and performance in construction projects" (Ward, Curtis \& Chapman, 1991) wordt ingegaan op het achterhouden van informatie over vertragingen en

kwaliteitsproblemen als een symptoom van een gebrek aan vertrouwen. Deze informatie wordt soms niet en soms pas op een voor de opdrachtnemer gunstig moment gedeeld met de opdrachtgever. Hieruit spreekt een duidelijke tekortkoming als het gaat om betrouwbaarheid van informatie uitwisseling, die de opdrachtgever duidelijk en bewust op het verkeerde been zet. Drexler \& Larson (2000) beschrijven het agressief omgaan met meerwerkdiscussies, het achterhouden van informatie en het uitspelen van tekortkomingen in contracten en/of bestekken als symptomatisch voor een gebrek aan vertrouwen. Met het oog op projectsucces, zijn dit allemaal ronduit ongewenste gedragingen. Korczynski (1996) komt tot het inzicht dat er twee routes zijn die de opdrachtgever kan volgen $n r 1$ Competitive low trust route; gebaseerd op uitgewerkt bestek en focus op laagste prijs (Korczynski, 1996). Aannemer heeft pas in een laat stadium inbreng, wat innovatie remt en de uitvoerbaarheid van het project niet bevordert (Korczynski, 1996; Dubois and Gadde, 2002). Maakt bovendien parallel ontwerpen en uitvoeren onmogelijk waardoor tijdsbesparingen beperkt worden (Cheung et al, 2001)

$n r 2$ Cooperative high trust route. Gericht op integratie van ontwerp en uitvoering, door vroege betrokkenheid van aannemers (Korczynski, 1996). Dit leidt weer tot betere samenwerking en meer integratieve benadering wat bijdraagt aan efficiënte oplossingen met added Value (Korczynski, 1996; Barlow et al, 1997; Briscoe et al, 2004). Het is belangrijk dat al tijdens de aanbesteding de basis gelegd wordt voor goede samenwerking, want alleen dan zal de aannemer 'het achterste van zijn tong laten zien' en optimale bijdrage leveren in de ontwerp- en voorbereidingsfase. Gezamenlijk vast te stellen specificaties in combinatie met incentive based compensation en het uitnodigen van een beperkt aantal marktpartijen, dat in staat is het project tot een succes te maken moet daarom deel uit maken an deze route. Bij het aanbesteden van complexe projecten lijken de voordelen van de tweede route evident (Korczynski, 1996).

\section{Samenvattend:}

Van traditioneel aanbesteden gaat geen bevorderende werking uit als het gaat om onderling vertrouwen. De traditionele benadering bevat, zoals we eerder zagen, 'weeffouten' die leiden tot een matige voorspelbaarheid van de aanbesteding. Traditioneel aanbesteden triggert bij opdrachtgever en opdrachtnemer het nastreven van eigen belangen, desnoods ten koste van belangen van de ander. Benaderingen die 'bouwen aan vertrouwen' leiden echter tot lagere transactiekosten, betere samenwerking, meer projectsucces. Nederland wijkt niet af van de internationale tendens op dit gebied. 


\section{Veel beslissingen en risico bij opdrachtgever}

Omdat de opdrachtgever bij een traditionele aanbesteding het hele project (ondersteund door adviseurs) bepaalt en alle technische specificaties onder zijn verantwoordelijkheid en risico vastgelegd worden, zijn alleen de uitvoeringsrisico's (maken wat de opdrachtgever heeft bedacht binnen de afgesproken tijd en prijs) voor de opdrachtnemer (Bremer, Kok, 2000; Pries et al, 2006). In het rapport "Innovatief aanbesteden: creativiteit in gebondenheid" van het College Bouw Zorginstellingen" (good practise cahier drie, 2006) wordt deze asymmetrische risicoverdeling in het bijzonder genoemd als één van de nadelen van traditioneel aanbesteden. Bij de succes voorbeelden die in dit cahier aan de orde komen is in vrijwel alle gevallen te zien dat risico verdeling evenwichtiger plaatsvindt.

Risicomanagement aan de zijde van de opdrachtnemer blijft meestal beperkt tijdens de aanbestedingsfase. Uit onderzoek van Price Waterhouse Coopers ("De aanbestedingspraktijk van de Rijksoverheid van 1996 - 2001"; juli 2002) blijkt dat in slechts $40 \%$ van de gevallen een risicoanalyse in het dossier aanwezig is. Bijna altijd beperkt deze analyse zich tot de bekende veiligheids-, gezondheids- en milieu (VGM) aspecten. Om de risico's beheersbaar te houden zoeken opdrachtgevers hun heil in het voorschrijven van normen, het stellen van hoge (soms te hoge en dus disproportionele) eisen en in een bekende, vertrouwde en ogenschijnlijk veilige route. Rahman \& Kumaraswamy (2002) stellen dat het leren kennen en effectief vaststellen van projectrisico's gebaat is

bij teamwork waarin verschillende partijen vanuit hun deskundigheid samenwerken. Hun pleidooi komt erop neer dat een risicoverdeling die tot stand komt op basis van constructieve samenwerking zowel opdrachtgever als opdrachtnemer uiteindelijk voordeel op zal leveren. Het EIB signaleert in het onderzoek "Opdrachtgevers aan het woord 2007" dat opdrachtgevers wat dit betreft hand in eigen boezem moeten steken. Opdrachtgevers hebben nog steeds de neiging zich te veel te bemoeien met het bouwproces, en tegelijkertijd te weinig verantwoordelijkheid bij de opdrachtnemer te leggen. De 2008 meting ("Opdrachtgevers aan het woord, 2008" EIB) laat op dit punt nog steeds een zelfde beeld zien.
Samenvattend:

Bij traditioneel aanbesteden wordt doorgaans weinig aandacht besteed aan risicomanagement. Als er al aandacht aan wordt besteed gaat het veelal om VGM ${ }^{104}$ risico's. Het in een vroeg stadium stilstaan bij risico's en maatregelen die kunnen bewerkstelligen dat ze niet optreden en/of dat gevolgen beperkt worden, komt de kwaliteit van het bouwproces en het eindresultaat daarvan ten goede. Vanuit die gedachte zouden risico's gealloceerd moeten worden bij die partij die het beste in staat is ze te managen. Verdeling van risico's tussen opdrachtgever en opdrachtnemer op basis van dit uitgangspunt, zou vast onderdeel van de pre-contractuele fase moeten zijn.

\section{Samenvattend en afrondend}

Traditioneel aanbesteden schiet tekort als het gaat om complexe bouwopgaven. Deze aanpak kan wel prima voldoen voor het aanbesteden van bekende, eenvoudige opgaven. De belangrijkste tekortkomingen zoals ze hiervoor geschetst zijn:

Marktpartijen hebben, wanneer alternatieven uitgesloten worden, geen ruimte om hun recente ervaringen en kennis in te brengen doordat opdrachtgevers een vast omschreven en 'dichtgetimmerd' bestek op de markt brengen,

De 'laagste-prijs-klem' lokt als het ware opportunistisch gedrag uit en leidt onevenredig veel aandacht naar de laagste initiële kosten, in plaats van bijvoorbeeld naar een goed en langjarig verantwoord te exploiteren bouwwerk,

De strikte scheiding tussen ontwerp en realisatie remt innovatie en bemoeilijkt samenwerking ${ }^{105}$

Opdrachtgevers vinden opdrachtnemers maar in beperkte mate betrouwbaar en voorspelbaar in hun doen en laten. Dat geldt overigen vice versa evenzo,

De traditionele verantwoordelijkheidsverdeling tussen opdrachtgever en opdrachtnemer bevordert samenwerking tussen beiden vaak niet Door een grote behoefte aan controle en control, mede veroorzaakt door een hoge mate van fragmentatie in de bouwketen, zijn transactiekosten hoog.
${ }^{104}$ Veiligheid,

Gezondheid, Milieu

${ }^{105}$ Zie ook "Gunnen op prijs en kwaliteit" (Pries \& Keizer,

2006) 


\section{Bijlage II}

pips in detail

\section{Request For Proposal (RF)}

Een pips aanbesteding begint ermee dat de opdrachtgever een aanbestedingsdocument opstelt waarin de informatie is opgenomen die relevant is voor inschrijvers om een passend aanbod te kunnen doen. Behalve de scope (technisch- ofwel, naar duidelijke voorkeur van Kashiwagi, functioneel gespecificeerd; op vo ${ }^{106}$ niveau of op besteksniveau) van

het project wordt in dat document ook de pips aanpak beschreven en worden de beoordelingscriteria en bijbehorende wegingsfactoren opgenomen. Pips kijkt zowel naar prijs als naar performance. Performance is op te splitsen in past performance én in het vermogen om het onderhavige project tot een goed resultaat te brengen (current capability). Het is dus zaak de verhouding tussen prijs en performance in dit document helder te maken. Dat geldt evenzo voor de verhouding tussen past performance en current capability. Deze current capability wordt berekend aan de hand van een aantal aspecten, dat ook weer een onderlinge relatieve weging kent [7-14]. Aldus ontstaat een beoordelingsstructuur naar onderstaand voorbeeld:

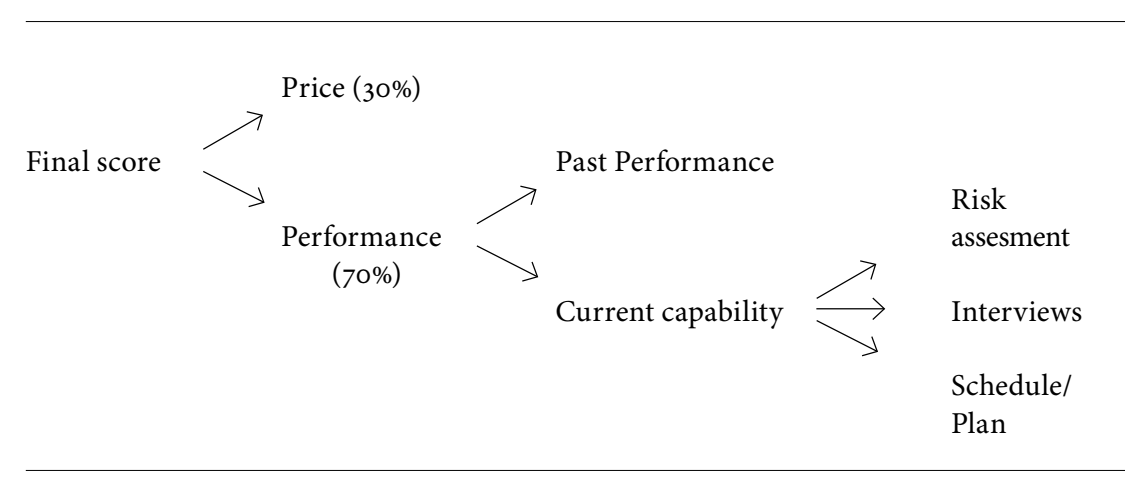

Afbeelding II.1; Beoordelingsstructuur 
Overigens adviseert Kashiwagi voor een pips aanbesteding in de Best Value categorie een $70 / 30$ verhouding tussen performance en prijs [7-15]. Tot slot adviseert Kashiwagi om ook de hoogte van het voor het project beschikbare budget in de $\mathrm{RFP}^{108}$ op te nemen. Achterliggende gedachte daarbij is dat een high performer daardoor in staat is zoveel mogelijk waarde voor het beschikbare geld aan te bieden [7-18].

\section{Past Performance Information (PPI)}

Bij een pips aanbesteding moeten inschrijvers zich voor het verzamelen van PPI wenden tot voormalige opdrachtgevers. Deze voormalig opdrachtgevers wordt gevraagd een standaard vragenlijst (gaat vergezeld van een korte instructie [7-27]) in te vullen en op 8 aspecten een score toe te kennen. Deze scores worden uitgedrukt in een rapportcijfer van één tot tien. In de loop der jaren (pirs is sinds het ontstaan begin jaren negentig voortdurend verder ontwikkeld) is deze vragenlijst enorm gereduceerd. Het aantal onderwerpen is teruggebracht tot acht. De reden die Kashiwagi daarvoor opgeeft is dat deze acht aspecten verantwoordelijk blijken voor het onderscheidende vermogen. Bijkomend voordeel van deze aanzienlijke reductie (de eerste versie bevatte tientallen aspecten!) is dat de inspanning en het tijdbeslag van voormalige opdrachtgevers hierdoor teruggedrongen wordt. Na invulling van de vragenlijst wordt deze rechtstreeks naar de aanbestedende partij gezonden

De acht onderwerpen waarvoor een score wordt gevraagd:

${ }^{n r} 1$ Het vermogen om projectkosten te managen

$n r 2$ Het vermogen om de planning aan te houden en waar te maken

nr 3 Vakmanschap

${ }^{n r} 4$ Professionaliteit en coördinatievermogen

${ }^{n r} 5$ Afronding en overdracht

$n r 6$ Tijdige en open communicatie en uitleg m.b.t. risico's nr 7 Werken conform (huis)regels

$n r 8$ Mate waarin tevredenheid reden vormt opnieuw in business te gaan met opdrachtnemer

Bij het verzamelen van past performance informatie hanteert Kashiwagi altijd deze 8 onderwerpen, ongeacht het type project [7-11].

Vervolgens telt het aantal projecten en het aantal verschillende opdrachtgevers (waarvan een ingevulde vragenlijst is ontvangen) mee bij de uiteindelijke PPI score van elke inschrijver. Voor relatieve nieuwkomers impliceert dit al snel dat bij het PPI filter een lagere score word gehaald ${ }^{109}$. Ultieme consequentie kan bij een pips aanbesteding dan ook zijn dat dergelijke relatief onervaren inschrijvers snel 'buiten de boot vallen'.
${ }^{109}$ Relatieve nieuwkomers beschikken immers (nog) niet over veel referentieprojecten.

\section{Past Performance Criteria}

\section{Criteria}

$n r 1$ Ability to manage the project cost (minimize change orders)

$n r 2$ Ability to maintain project schedule (completed in time or

nr 3 Quality of workmanschip

$n r 4$ Professionalism and ability to manage, including responses and prompt payment to suppliers and subcontractors

${ }^{n r} 5$ Close out process (no punch list items, warranty documents,

$n r 6$ Communication, explanation of risk, and documentation

$n r 7 \quad$ Ability to follow the user's rules, regulations and requirements

nr 8 (housekeeping, safety, etc.)

8 Overall customer satisfaction and comfort with rehiring the

$n r 9$

nr 10 Total number of different customer responses 
${ }^{110}$ Omdat alle inschrijvers deze gelegenheid krijgen, is er volgens

Kashiwagi geen sprake van discriminatie.

${ }^{111}$ In verband met de in Nederland gehanteerde (bij de niet openbare procedure) strikte scheiding tussen selectie- en gunningsfase, is het zaak al bij de selectie van geschikte aanbieders rekening te houden met de relevantie van past performance projecten, en niet pas bij het selecteren van de meest gunstige aanbieding.

${ }^{112}$ Vanaf 2007 is Kashiwagi de term RAVA (Risk Assessment Value Added) gaan hanteren.
Nummer negen en tien in afbeelding II.2 geven respectievelijk het aantal verschillende projecten en het aantal verschillende opdrachtgevers weer. Dat zijn dus geen items waar aan de voormalig opdrachtgevers een score hoeven toe te kennen.

Het verzamelen van PPI kan, afhankelijk van het project, enkel gedaan worden voor de hoofdaannemer, maar ook per perceel, en/of voor kritische onderaannemers [7-16, 7-24]. pips stelt inschrijvers in de gelegenheid van zoveel mogelijk goed uitgevoerde projecten PPI aan te laten leveren ${ }^{110}$. Dat stelt inschrijvers in de gelegenheid ook PPI van projecten aan te laten leveren die minder goed vergelijkbaar zijn met het onderhavige project. Kashiwagi stelt daar tegenover [7-21] dat je hiermee een shortlist samenstelt die beschikt over bewezen high performance; de volgende pips filters selecteren alleen die inschrijvers die over het vermogen beschikken om dit project tot een succes te maken $[7-21]^{111}$.

\section{Risk Assessment Plan (RAP)/RAVA (Risk Assessment Value Added)}

Het volgende filter bestaat uit het door inschrijvers laten maken van een RAP/RAVA ${ }^{112}$. In dat plan geven de inschrijvers de projectrisico's weer die ze (voor)zien en geven ze bovendien een prioritering aan. Ook gaan ze in op de wijze waarop ze (preventief en/of correctief) deze risico's zullen managen en minimaliseren. Zowel het verkleinen (en/of elimineren) van de kans dat een risico optreedt als het nadenken over het beperken van de effecten van risico's en het omzeilen ervan kan in dat plan de aandacht krijgen. Uit de RAP's spreekt als het ware de mate van inzicht en doorzicht met betrekking tot het project. Inschrijvers die vanuit professionele ervaring en deskundigheid een dergelijk plan schrijven, scoren beduidend hoger dan partijen die niet over de vereiste deskundigheid met betrekking tot het onderhavige project beschikken. Daarmee brengt dit filter een duidelijke scheiding aan tussen partijen die inderdaad in staat zijn risico's te verkleinen en te managen en partijen die daartoe in mindere mate in staat zijn [7-29].

Ook wordt inschrijvers gevraagd een globaal tijdschema op te stellen. De inschrijver neemt in die planning de uit te voeren activiteiten op en plant ze in de tijd. Een inschrijver die in staat is een project in deze fase realistisch te plannen en de samenhang van de uit te voeren activiteiten te doorzien, ontvangt een hoge score voor dit onderdeel. Ook wordt het risico van non-performance verkleind [7-29]. RAP/RAVA's moeten beperkt van omvang zijn [7-31] (alleen to the point informatie bevatten, Kashiwagi gaat uit van maximaal vijf A4's) en op blanco papier, zonder vermelding van bedrijfsnamen, logo's of andere zaken die de identiteit van de indiener 'verraden' worden ingeleverd. RAP/RAVA's worden omwille van de objectiviteit namelijk anoniem beoordeeld

[7-30]. Wanneer RAP/RAVA's elementen bevatten zoals onwaarschijnlijkheden, onrechtmatigheden, onwerkelijke en/of te fraaie voorstelling van zaken, zal dat behalve tot een lagere RAP/RAVA score ook leiden to lage scores tijdens het volgende filter; het interview met sleutelfunctionarissen [7-31]

Kashiwagi benadrukt dat het RAP/RAVA geen technisch geformuleerde gegevens, specificaties of oplossingen mag bevatten [7-32]. Het plan moet immers in de eerste plaats inzicht geven in te verwachten perfor mance en niet in toe te passen materialen en technieken. Een uitzondering maakt Kashiwagi voor die situaties waarin technische informatie een directe en significante link heeft met het te verwachten performance niveau [7-32]. Het RAP/RAVA geeft informatie over het vermogen om dit project tot een succes te maken; de current capability. Daarin ligt voor Kashiwagi het motief om te pleiten voor een hoger relatief gewicht voor het RAP/RAVA dan voor de PPI [7-32]. Wanneer het vermogen om het onderhavige project goed te kunnen realiseren zwaarder meeweegt, stimuleert dat de inschrijvers hun beste personeel op dit project in te zetten. Daarmee wordt het risico van under performance verder verkleind. Een ander motief is gelegen in het feit dat het bij PPI om projecten kan gaan die slechts weinig overeenkomsten vertonen met het project waarom het nu gaat [7-32]

Vanaf 2007 wordt bij dit onderdeel ook aan inschrijvers gevraagd welke waarde ze aan het werk toe kunnen voegen. Ze kunnen beschrijven welke optimalisaties ze vanuit hun knowhow en ervaring zien. Dat kunnen optimalisaties zijn in het ontwerp. Met betrekking tot maakbaarheid, met betrekking tot renderende exploitatie, op het gebied van toekomstbestendigheid etc. Deze optimalisaties worden vervolgens meegewogen om de kwaliteit van de oplossing te bepalen.

\section{Interviews}

De rol van sleutelfunctionarissen bij de uitvoering van een project is 
${ }^{113}$ Vanuit het non discriminatie

beginsel is er echter veel voor te zeggen projectleiders van

alle inschrijvers die bij dit filter nog "aan boord" zijn te inter-

viewen (zie ook hoofdstuk vier). evident. De kwaliteit van deze functionarissen drukt namelijk een stempel op de te verwachten kwaliteit bij dit project. Inschrijvers moeten daarom deze sleutelfunctionarissen met naam en toenaam benoemen en zichzelf ertoe verplichten dat deze personen ook daadwerkelijk ingezet worden wanneer bij gunning. Bij een grotere, complexere of risicovolle pips aanbesteding worden sleutelfunctionarissen geïnter-

viewd door een team van de opdrachtgever. Wanneer er veel inschrijvers zijn, kan op basis van informatie uit eerdere filters een shortlist samengesteld worden van inschrijvers die hoog scoren. Besloten kan worden alleen de sleutelfunctionarissen van die inschrijvers te interviewen ${ }^{113}$. Informatie die de opdrachtgever verwerft door middel van interviews:

- nadere toelichting op het RAP/RAVA wat kan leiden tot betere interpretatie ervan

- vaststellen of de sleutelfunctionarissen het RAP/RAVA goed begrijpen

competentieniveaus van sleutelfunctionarissen in relatie tot project

- informatie over sociaal, communicatieve vaardigheden

- competentieniveaus van sleutelfunctionarissen met betrekking tot samenwerken

Waar vooral op wordt gelet bij de interviews is in hoeverre de geïnterviewde persoon op de hoogte is van het uit te voeren project, of hij/zij doorziet waar zich de risico's bevinden, waarom de geïdentificeerde risico's volgens hem/haar een risico zijn en of de betreffende functionaris in staat is uit te leggen hoe deze risico's gemanaged zullen worden. Hoe directer en adequater een persoon reageert op interviewvragen, des te beter is de indruk die achtergelaten wordt. De vragen die worden gesteld tijdens de interviews dienen binnen één aanbesteding telkens hetzelfde te zijn. Ook de samenstelling van het interviewteam zou niet moeten variëren binnen één aanbesteding. Dit bevordert de vergelijkbaarheid en de gelijke behandeling van inschrijvers.

Kashiwagi geeft aan dat het interview een van de beste mechanismen is om risico's te verminderen [7-38]:

- Een face to face interview geeft directe informatie die het verschil (ervaring, deskundigheid, mate van competent zijn voor de klus) tussen sleutelfunctionarissen duidelijk maakt.
Ook verschillen in perceptie en verwachting tussen de projectmanager van de inschrijver en de vertegenwoordiger van de opdrachtgever worden op deze wijze duidelijk gemaakt.

- Het interview is een goede gelegenheid om de snelheid en het vermogen om informatie te verwerken van de projectmanager in beeld te krijgen (Sluit aan bij IMT, zie hoofdstuk drie)

Het verdient de voorkeur (zoals eerder vermeld) met een gestandaardiseerde vragenlijst te werken. Wel moet de ruimte genomen worden

'door te vragen' als antwoorden onvoldoende informatief zijn. Het belang van de interviewscore moet tot uitdrukking komen in het relatieve gewicht in de beoordelingsstructuur.

\section{Rating}

Wanneer de prijsinformatie, de PPI score, de RAP/RAVA score en de interviewscores bekend zijn, kan berekend worden (aan de hand van de relatieve gewichten uit de beoordelingsstructuur) welke inschrijver de hoogste score heeft en wat de relatieve afstand is tussen de overige inschrijvers. Kashiwagi hanteert daartoe een DIM: Displaced Ideal Model (oorspronkelijk ontwikkeld door Zeleny in 1984, Multiple Criteria Decision Making, JaI Press, Greenwich). Deze spreadsheet houdt rekening met:

- de hoogte van de scores

- hoeveelheid informatie (van hoeveel verschillende opdrachtgevers is bijvoorbeeld een PPI score bekend?)

- de wegingsfactoren die een opdrachtgever toekent aan de verschillende onderdelen.

De spreadsheet negeert aspecten die niet differentiëren, verschillen in scores die het onderscheidend vermogen juist benadrukken krijgen een hogere information factor; het gaat immers om een ranking en het berekenen van de relatieve afstand (Kashiwagi and Mayo, 2001) Als alle inschrijvers op deze manier tot een eindscore zijn gekomen, is het zaak een advies te formuleren. Kashiwagi hanteert daartoe onderstaande richtlijnen $[7-40]$ : 
- Wanneer de hoogst scorende inschrijver binnen het budget past, is het advies met deze inschrijver de pre-award fase in te gaan.

- Wanneer de hoogst geëindigde inschrijver boven het budget zit, is het advies met die opdrachtnemer verder te praten die het hoogst scoort binnen het budget.

- Wanneer de hoogst geëindigde inschrijver binnen budget past, maar toch een groter prijsverschil dan $10 \%$ heeft met de inschrijver die als tweede is geëindigd, beveelt Kashiwagi aan met deze tweede partij verder te praten als de performance scores minimaal verschillen.

- Als het performance verschil wel substantieel is verder praten met de hoogst geëindigde.

\section{Which Contractor Should You Select?}

(Budget $=100,000)$

\begin{tabular}{|c|c|c|c|c|}
\hline \multirow{2}{*}{$\begin{array}{l}\text { Ranking } \\
\text { DIM score }\end{array}$} & \multirow{2}{*}{$\begin{array}{l}\text { 1st } \\
95\end{array}$} & \multirow{2}{*}{$\begin{array}{l}\text { 2st } \\
79\end{array}$} & \multirow{2}{*}{$\begin{array}{l}3 \mathrm{rd} \\
54\end{array}$} & \multirow{2}{*}{$\begin{array}{l}4^{\text {th }} \\
51\end{array}$} \\
\hline & & & & \\
\hline Criteria & Firm 1 & Firm 2 & Firm 3 & Firm 4 \\
\hline Cost & $\$ 100,500$ & $\$ 94,000$ & $\$ 89,000$ & $\$ 95,500$ \\
\hline $\begin{array}{l}\text { 1-10 Average } \\
\text { Rating }\end{array}$ & 9,7 & 9,2 & 8,9 & 8,7 \\
\hline $\begin{array}{l}\text { Number of } \\
\text { Surveys }\end{array}$ & 12 & 5 & 3 & 5 \\
\hline \multicolumn{5}{|c|}{ Highest performer that you can afford } \\
\hline
\end{tabular}

Afbeelding II.3; Voorbeeld DIM score
Pre-Award

In deze fase krijgt de inschrijver die geselecteerd is de mogelijkheid alles tot in detail uit te werken. Zijn prijs staat echter vast zoals hij die ingediend heeft. De in het beknopte RAP geduide risico's en bijbehorende remedies worden verder uitgewerkt en geoperationaliseerd tot op he niveau dat de opdrachtnemer (hij moet die risico's immers accepteren en ze managen) een en ander beheersbaar vindt. Daarnaast vindt overleg plaats over de risicoverdeling met betrekking tot restpunten tussen opdrachtgever en opdrachtnemer. Ook de afstemming tussen en samenwerking met onderaannemers wordt verder uitgewerkt. De opdrachtnemer stelt zijn kwaliteitszorg en -borgings plannen op. Het globale tijdschema wordt verder uitgedetailleerd en de laatste onduidelijkheden of interpretatieverschillen worden besproken. De prijs wijzigt in deze fase niet, tenzij de opdrachtgever zelf wijzigingen initieert [7-42]. De besprekingsverslagen, tekeningen en andere relevante documenten die in deze fase opgemaakt worden, worden toegevoegd aan het contract en vormen een onlosmakelijk deel daarvan. De inschrijver is verant woordelijk voor een check ten aanzien van volledigheid en consistentie van de voor de contractering benodigde informatie.

Aan het einde van de pre-award fase moeten opdrachtgever en opdrachtnemer alle nog openstaande vragen hebben beantwoord en moet de opdrachtnemer dus garant kunnen staan voor realisatie van het gevraagde, binnen planning en budget. De opdrachtgever op zijn beurt moet met een gerust hart het project en de daarbij behorende risico's over kunnen dragen aan de geselecteerde inschrijver. Als ee van beide partijen aan het einde van de pre-award fase nog een of meerdere voorbehouden maakt, wordt (nog) niet overgegaan tot gunning [7-43].

\section{Uitvoeringsfase}

Tijdens de uitvoering is het werk aan opdrachtgeverszijde geminimaliseerd. Er is immers een high performer geselecteerd die verantwoordelijk is voor het tijdig, binnen budget en volgens verwachtingsniveau opleveren van het gevraagde bouwwerk. Kashiwagi zegt daarover [7-45]:

"Performers need encouragement and are given the freedom to make 
their own decisions. Non-performers need to be told what to do because they do not know what to do. Therefore, when managing performers, the amount of information needs to be minimized, and when managing non-performers the amount of information needs to be maximized."

Wel zullen relevante (en soms wettelijk voorgeschreven) inspecties uitgevoerd worden. Het 'kat en muis spel' tussen opdrachtgever (opzichter) en opdrachtnemer (uitvoerder) is echter veel minder prominent aanwezig. De opdrachtnemer heeft ingeschreven in de wetenschap dat hij niet op laagste prijs, maar op hoogste waarde voor het beschikbare budget geselecteerd zou worden. De opdrachtnemer is daardoor in staat een 'gezonde' marge te draaien, en heeft het project naar zijn hand kunnen zetten waardoor hij zich kan concentreren op voortgang conform planning. De opdrachtnemer heeft er meer belang bij daadwerkelijk high performance te leveren, wat zijn kansen op toekomstig werk vergroot (zie ook post construction rating verderop). De interface tussen opdrachtgever en opdrachtnemer wordt tijdens de uitvoeringsfase gedomineerd door het uitwisselen van stuurinformatie met betrekking tot risico's op overschrijding van budget en/of planning en het realiseren van het verwachtingsniveau van de opdrachtgever. De opdrachtnemer maakt daartoe een weekrapport waarin hij aangeeft:

- Geprioriteerde risico's

- Voortgang

- Plannning

- Budget

- Meerwerk en impact daarvan op planning, budgeten kwaliteit.

In de ultieme vorm kan deze stuurinformatie uitgedrukt worden in één wekelijks getal: het risk number. Dit getal wordt aan de hand van onderstaande formule wekelijks bepaald en aan de opdrachtgever gerapporteerd. Risk Number (RN):

$\mathrm{RN}=(1+\% \mathrm{OT}) \mathrm{x}(1+\% \mathrm{OB}) \mathrm{x}(11-\mathrm{CS})$

$\mathrm{OT}=$ On Time

$\mathrm{OB}=$ On Budget cs = Customer Satisfaction (moet zijn 10)

Het wekelijkse risk number moet dus idealiter de waarde " 1 " hebben. Dit getal is gebaseerd op inschattingen van de opdrachtnemer t.a.v. verwachte budget- en planningsoverschrijding en op de mate waarin de opdrachtnemer denkt af te wijken van de verwachtingen van de opdrachtgever. De opdrachtnemer meet dus zijn eigen performance. Indien de opdrachtnemer de neiging zou hebben zaken aanvankelijk mooier voor te stellen dan ze zijn, treedt in de loop van het project een plotselinge trendbreuk op in de hoogte van het risk number. Het is dan voor de opdrachtnemer moeilijk aannemelijk te maken dat er 'ineens' sprake is van een forse dreigende overschrijding of kwaliteitsmanco. Dit mechanisme bewerkstelligt dat de opdrachtnemer in een vroeg stadium dreigende afwijkingen zal delen met de opdrachtgever en deze dreigingen meteen van een adequate interventie zal voorzien.

Dit wordt nog versterkt door de post construction rating. (deze informatie is afkomstig van de jaarlijkse conference 2005, is niet direct terug te vinden in het boek Best Value Procurement, editie 2004).

\section{Post Construction Rating}

$\mathrm{Na}$ voltooiing van het project blikt de opdrachtgever terug op de door de opdrachtnemer geleverde performance. Dit levert een score op tussen één en tien. Deze score weegt voor $50 \%$ mee bij het verkrijge van toekomstige aanbestedingen ${ }^{114}$. Een hoge score levert een voordeel op ten opzichte van andere inschrijvers. Bij een lage score is het omgekeerde het geval.
${ }^{114}$ In hoofdstuk vier wordt stil gestaan bij de juridische haalbaarheid van dit element binnen het juridisch kader zoals dat hier geldt. 
Questionnaire Performance Information Procurement System (PiPs)

Version1.o-andries.vanbentum@nl.corio-eu.com

Name:

Company:

Date:

$n r \mathbf{1}$

\section{Criteria}

Approximately what percentage of your

contractors who usually participated in the

conventional procurement method could live

up to the expectations/requirements of pips?

nr 2 What percent of the projects have been involved in any claims from contractors for using the pips-method?

nr 3 The position of power is used by the client to make constructors participate in the pips-tender?

nr 4 The more complex the project is, the smaller the chances are to successfully procure with pips.

${ }^{n r} 5$ I would hire a low-performer for a "low-profile" project in the future, instead of using pips? For the more complex project however I would use the pips system.

${ }^{n r} 6$

Contractors don't really knowhow to respond to the pips process because there is little education for the contractors.

nr 7 Contractors should be educated on the same level as the core-team of the client.
Unit

Rating 
What would you recommend to new pips-users?

What would you advise against to new pips-users?

* 10 means that you strongly agree with the statement and means that you

strongly disagree.

\section{Bijlage IV}

\section{Innovatieve pips elementen}

Uit de beschrijving van de pips werkwijze is een aantal los toepasbare innovatieve elementen te herleiden. De veronderstelling is dat elk van die elementen een bijdrage kan leveren aan het verbeteren van aanbestedingen en aan het managen van projecten tijdens de uitvoeringsfase. Bij de praktijkcases die in hoofdstuk vijf worden beschreven is een aanta van deze elementen toegepast en hun werking en effecten beschreven. Onderstaand worden de elementen 'vet' weergegeven en van een korte toelichting voorzien. De afkorting die er tussen haakjes achter staat vermeld, correspondeert met de in hoofdstuk zes gebruikte weergaven).

Project op de markt zetten op basis van een oplossingsvrij gespecificeerde vraag i.p.v. uitgewerkt bestek + tekeningen (Funcspec)

Dit element gaat over de vraagspecificatie. Uitgangspunt is dat wanneer deze vraagspecificatie zodanig is opgesteld dat er ruimte overblijft voor inschrijvers om hun recente ervaringen en kennis van zaken in te brengen, dit tot waardecreatie leidt. Inschrijvers worden daardoor vroeger bij het project betrokken, de strikte scheiding tussen ontwerp en uitvoering verdwijnt en er wordt een appèl gedaan op het vakmanschap; inschrijvers worden immers uitgedaagd met doordachte oplossingen en uitwerkingen te komen.

Informeer gegadigden van meet af aan over het maximale budget dat aangewend zal worden om te voorzien in de gevraagde oplossing (Budgetinf)

Dit stelt high performers in de gelegenheid maximum value for money te bieden binnen de financiële mogelijkheden; zo krijg je het beste wat je je kunt veroorloven. Aanbiedingen van inschrijvers die dit maximum bedrag overschrijden, kunnen ter zijde worden gelegd.

\section{Gebruik Past Performance Information (PPI) bij selectie van} partijen (PPI)

Dit element handelt over het gebruiken van PPI bij aanbestedingen. Uitgangspunt is dat gebruik van deze PPI helpt bij het selecteren van partijen die in staat zijn voor het beschikbare budget hoge projectwaarde 
te creëren tegen een laag risiconiveau. Dit is gebaseerd op de veronderstelling dat in het verleden behaalde resultaten een bruikbare indicator vormen voor te verwachten performance.

\section{Laat inschrijvers een Risk Assesment Plan (RAP/RAVA) indienen} (RAVA)

Door inschrijvers te vragen projectrisico's te duiden, ze te prioriteren en aan te geven hoe ze denken de risico's te minimaliseren en managen, krijg je veel inzicht in vakmanschap, inzicht en doorzicht in het project en zal de uitvoering van het project ook efficiënter verlopen. De risico's zijn ofwel door preventieve maatregelen geëlimineerd en voor risico's die zich toch manifesteren is al nagedacht over remedies.

Daarnaast wordt in het RAP/RAVA aandacht besteed aan door de marktpartij ingebrachte optimalisaties. Behalve ten aanzien van risicomanagement, kunnen marktpartijen zich door middel van het RAP/RAVA ook onderscheiden met de kwalieit van hun oplossing.

Meewegen van de kwaliteit van sleutelfunctionarissen (Qsleutelf) Je contracteert uiteindelijk een rechtspersoon. Toch zijn het vaak de mensen die het verschil maken. 'De vent is belangrijker dan de tent' (SBR, "haal het beste uit de bouw", februari 2006). Om die reden is het handig Cv's (en eventueel PPI) van sleutelfunctionarissen op te vragen en met deze mensen een interview te houden. Daar moet uiteraard aan verbonden worden dat inschrijvers toezeggen bij gunning ook daadwerkelijk deze mensen in te zetten. Interviews moeten zodanig worden georganiseerd dat alle partijen gelijke kansen krijgen en dat een zekere mate van objectiviteit wordt gewaarborgd.

\section{Richt de aanbesteding value based in plaats van price based in}

\section{(Pr/kwal)}

Oriëntatie op waarde in plaats van op laagste prijs lijkt projectsucces gunstig te beïnvloeden. Focus op laagste prijs werkt fouten in de hand. De aannemer zal proberen zijn benodigd rendement toch te realiseren door de inzet van lager geschoold personeel, 'mindere' materialen en het zoeken van 'gaten in het bestek' die vertaald kunnen worden naar meerwerk nota's. Per project zal situationeel bezien moeten worden welke relatieve verdeling tussen prijs en prestatie in dat geval het meest

\section{adequaat is.}

\section{Draag projectrisico's over aan de partij aan wie je het project gunt} (Risktrans)

Dit element handelt over het overdragen van risico's aan die partij die deze risico's het best kan beïnvloeden en daarmee deze partij ook verantwoordelijk maken voor het omgaan met deze risico's. Het overdragen van projectrisico's wordt ingegeven door de gedachte dat de opdrachtgever nadat hij een high performer heeft geselecteerd ook de ruimte aan die aannemer moet geven om het project op zijn wijze te realiseren. Gebaseerd op en uitgaande van realisatie conform planning, budget en verwachte en overeengekomen kwaliteit. Ook de property rights theorie (zie hoofdstuk drie) indiceert dat het al dan niet hebben van eigenaarschap van risico's er toe doet.

\section{Zorg dat je beschikt over harde performance data (Harddat)}

Tijdens de uitvoering van het project meet de opdrachtnemer zijn eigen performance en rapporteert hij daar periodiek over. Meting en rapportage hebben betrekking op werken conform planning, binnen budget en conform kwaliteitsverwachtingen zoals overeengekomen. Op afstand managen van een project is verantwoord mogelijk als er op bijvoorbeeld wekelijkse basis inzicht wordt verschaft in dreigende budget- of plannings overschrijdingen en in dreigende kwaliteitsproblemen.

\section{Post Construction Rating (PCR)}

De opdrachtgever kent de opdrachtnemer na oplevering van het project een score toe. Deze score geeft, al naar gelang de hoogte, deze opdrachtnemer bij een nieuwe aanbesteding op voorhand een voorsprong danwel een achterstand op andere mededingers. 
Beschrijving NIE die aanvullende informatie geeft bij de hoofdtekst van hoofdstuk drie.

TCE

Het karakteriseren van transacties

Volgens Williamson $(1979,1985)$ zijn er drie kritische dimensies om transacties te karakteriseren:

${ }^{n r} 1$ Transactiespecificiteit van de investering. Williamson (1985) "Asset specificity is the most critical dimension to discribe a transaction". Speklé (2001) borduurt daarop voort en onderkent verschillende vormen van specificiteit:

- Plaatsgebonden specificiteit

- Fysiek gebonden specificiteit

- HRM specificiteit (je moet personeel met specifieke competenties hebben)

- Dedicated investeringen

- Specifieke merknaam (Intel inside effect)

- Tijd gebonden specificiteit

nr 2 Onzekerheid. Williamson zegt daarover: onzekerheid is synoniem voor complexiteit. Onzekerheid speelt niet bij non specifieke transacties omdat daar de neiging tot opportunisme gering is. Coördinatiekosten zijn dus gerelateerd aan mate van specificiteit en mate van onzekerheid. Graham Winch (1989) onderscheidt vier vormen van onzekerheid die een rol spelen bij bouwprojecten:

- Taak onzekerheid: nieuwe projecten vragen telkens om nieuwe kennis. Het geleerde op een bepaald project is maar deels bruikbaar bij een volgend project. 
- Geologische en meteorologische onzekerheid.

- Organisatorische onzekerheid: projectcoalities moeten per project worden aangegaan wat onzekerheden met zich meebrengt met betrekking tot vakbekwaamheid, gedrag, samenwerking, complementariteit etc.

- Contractingsonzekerheid: er wordt in de regel in concurrentie ingeschreven. Hoe schrijven andere aanbieders in? Inschrijven gaat gepaard met veel aannames en interpretaties, gebaseerd op het referentiekader waarover de inschrijver beschikt. Het is geen 'hogere wiskunde'. Deze onzekerheid brengt continuïteitsonzekerheid met zich mee. Het missen van een aanbesteding kan flinke impact hebben op omzet en winst.

${ }^{n r} 3$ Frequentie. Hoe vaker een transactie voorkomt, hoe eerder je geneigd zult zijn voor de hiërarchie te kiezen om hoge transactiekosten via de markt te voorkomen.

\section{Het categoriseren van transacties}

Naast de drie hiervoor behandelde dimensies aan de hand waarvan transacties zijn te karakteriseren, categoriseert Williamson transacties waarbij hij zes verschillende transactietypen, geordend langs twee assen, onderscheidt:

$n r 1$ Frequentie (incidenteel of herhaaldelijk. Occasional or recurrent; hoe lager de frequentie, hoe groter het gevaar van opportunistisch gedrag. Bedenk hierbij dat aanbesteding van utiliteitsprojecten voor veel opdrachtgevers een laag frequente aangelegenheid is)

$n r 2$ Specificiteit van de activa (naar vestigingsplaats, specifieke fysieke activa, specifieke deskundigheid)

Vervolgens koppelt Williamson de frequentie aan de transactie specificiteit in drie gradaties: Non specifiek, gemengd en specifiek. Aldus ontstaat onderstaand schema, gebaseerd op de doctoraalscriptie van Stip (vu Amsterdam, 1995).

\section{Investerings karakteristiek van de transactie}

$\begin{array}{llll}\begin{array}{l}\text { Frequentie van de } \\ \text { transactie }\end{array} & \begin{array}{l}\text { Non } \\ \text { specifiek }\end{array} & \text { Gemengd } & \text { Specifiek } \\ \text { Incidenteel } & \text { A markt } & \text { B markt } & \text { C markt } \\ \text { Herhaaldelijk } & \text { D markt } & \text { E markt } & \text { F hierarchie }\end{array}$

Tabel v.1; Zes types transacties volgens Williamson

Merk hierbij op dat de meeste utiliteitsbouwprojecten van het type ' $C$ ' zijn, en dus is organiseren 'via de markt' voor de hand liggend. Bij organiseren van een dergelijke type ' $C$ ' transactie via de hiërarchie zou de organisatie onevenredig belast worden vanwege lage de frequentie en de ontbrekende competenties en een bedrijfsvoering die niet ingericht is op deze laag frequente activiteit.

\section{Transactiekosten}

De Goei en Simons publiceerden in het NEHA (Nederlands Economisch Historisch Archief) jaarboek 2002 een artikel met de titel: “Transactiekosten in theorie en praktijk. De kosten van het Handelsregister in de twintigste eeuw". Daarin geven ze aan dat de transactiekosten in de Amerikaanse economie omstreeks 1870 ca. $25 \%$ en omstreeks 1970 ca $50 \%$ van BNP (Wallis en North, "Measuring the transaction sector" 1986 ) bedragen. Als verklarende factoren voor deze toename geven ze aan:

- Specialisatie en arbeidsdeling nemen toe

- Technologische veranderingen in productie en transport

- Toename bedrijfsgroottes

- Grotere rol overheid 
De Nederlandse econoom De Vor heeft gedurende de periode 1947-1990 het aandeel van transactiekosten in de Nederlandse economie gemeten. Zijn conclusie is dat ook in Nederland de transactiekosten in de onderzoeksperiode zijn gestegen van $30-40 \%$ in 1947 tot $50-52 \%$ van het BNP in 1990. De Vor geeft als extra verklarende factor ten opzichte van Wallis en North: het toenemende onpersoonlijke karakter van actoren in de economie als gevolg van toenemende specialisatie. Dat werkt opportunisme in de hand. Dat vraagt weer om extra safeguards en het verder specificeren van bepalingen in contracten. Dit alles kost volgens De Vor meer tijd, waardoor de transactiekosten stijgen. De concrete meetbaarheid van transactiekosten vormt een complex probleem. Transactiekosten en productiekosten lopen in de praktijk door elkaar heen. Dat maakt dat ze moeilijk zijn te meten. Afbakening en definiëring van het begrip transactiekosten kan daarbij helpen.

Kenneth Arrow (1969, p. 49) geeft als definitie:

transaction costs:

"costs of running the economic system"

Williamson (1996, p. 379)

"the ex ante costs of drafting, negotiating, and safeguarding an agreement and more especially, the ex post costs of maladaptation and adjustment that arise when contract execution is misaligned as a result of gaps, errors, omissions and unanticipated disturbances"

Transactiekosten komen dus bovenop productiekosten. Vragers, aanbieders en derden hebben met transactiekosten te maken. Voorbeelden: zoekkosten, opstellen van een contract, houden van toezicht. Kortom alle kosten die samenhangen met "information, negotiation and enforcement" (Williamson, 1985).

Om nog wat verder in te zoomen op de transactiekosten is het onderscheid tussen ex ante en ex post kosten (zoals ook in de hierboven cursief weergegeven definitie wordt gemaakt) goed bruikbaar. Williamson betoogt in zijn artikel "The economic Institution of capitalism" (1985) dat ex ante en ex post kosten in samenhang en gelijktijdig onder de loep genomen moeten worden. Ze beïnvloeden elkaar namelijk. Bij het organiseren van een transactie moet dus rekening gehouden worden met beiden. Williamson onderscheidt beide vormen van transactiekosten als volgt:

\section{Ex ante:}

- Kosten van ontwerpen, onderhandelen en het aanbrengen van zekerheidsstellingen, bepalingen en clausules in contracten

- Informeren handelspartners

- Zoeken en selecteren, verzamelen van informatie over reputatie, kredietwaardigheid, prijsstellingen van opdrachtnemers

Ex post:

- Kosten van afdwingen van naleving van gemaakte afspraken in het kader van de overeengekomen transactie

- Kosten van 'bewerken', onderhandelen, informeren bij zowel opdrachtgever als opdrachtnemer om 'ontsporingen' of fricties in belangen te slechten

- Kosten van het organiseren en uitvoeren van arbitrage

- "Monitoring and bonding costs of effecting secure commitments"

- Kosten van contractaanpassingen in geval van wijzigingen

- Kosten als gevolg van het anders naleven door contractpartij dan verwacht.

\section{Contractvormen}

Williamson onderscheidt daarnaast drie vormen van contracten:

$n r 1$ Klassieke contracten:gebaseerd op ruil, consequenties zijn meteen duidelijk. Verwerving van goed definieerbaar product. Gebaseerd op de 'volkomen markt'. Gevolgen van uitvoering van het contract zijn goed voorspelbaar en definieerbaar. Transactiekosten zijn laag doordat partijen niet in relatie hoeven te investeren en omdat teruggevallen kan worden op standaardcontracten. Monitoring en afdwingen van naleving vindt plaats aan de hand van zelfexecuterende transacties als waarborg. Bijvoorbeeld: afgetekende pakbon niet aanwezig; factuur wordt niet betaald. 
$n r 2$ Neo klassieke contracten: niet alles is inzichtelijk, 'alles' regelen zou zeer kostbaar worden of zelfs onmogelijk. Je bouwt dan een sturingsstructuur in, en haalt er een derde bij om de prestaties te evalueren wanneer je er samen niet uitkomt (arbitrage). Deze contractvorm is vooral geschikt voor transacties met een incidenteel karakter gecombineerd met de noodzaak tot hoge investeringen door de opdrachtnemer. Typerend is: het besef dat de wereld complex is, dat overeenkomsten incompleet zijn en dat contracten nooit volledig uitgevoerd zullen worden als partijen geen vertrouwen hebben in de wijze waarop de contracten tot stand komen, ten uitvoer worden gebracht en worden bewaakt. Niet op alle contingenties kan worden geanticipeerd in het contract. Drie opties in neo klassieke contractvorm:

- Nul optie; geen contract afsluiten

- Niet via de markt, maar via de hiërarchie organiseren

- Klassieke contractmodel aanvullen met besturings- en bewakingsstructuur. Bijvoorbeeld door het toevoegen van arbitrage en daarmee een soort van drie partijen contract.

${ }^{n r} 3$ Relationeel contract:voor nog complexere situaties. Soort van mini gemeenschap met een reeks normen en afspraken.

Frequente transacties met hoge investeringskarakteristiek. Er ontstaat een transactiespecifiek continu aanpassingsproces.

Onderlinge relatie staat centraal.

Williamson koppelt deze verschillende contractvormen aan de eerdere ordening van transacties langs de lijnen specificiteit en frequentie en komt zo tot het volgende overzicht.

\section{Investerings karakteristiek voor opdrachtnemers}

\begin{tabular}{llll} 
& $\begin{array}{l}\text { Non } \\
\text { specifiek }\end{array}$ & Gemengd & Specifiek \\
Incidenteel & $\begin{array}{l}\text { A markt; } \\
\text { klassiek } \\
\text { contract }\end{array}$ & $\begin{array}{l}\text { B markt; } \\
\text { neo klassiek } \\
\text { contract }\end{array}$ & $\begin{array}{l}\text { C markt; } \\
\text { neo klassiek } \\
\text { contract }\end{array}$ \\
Herhaaldelijk & $\begin{array}{l}\text { D markt; } \\
\text { klassiek } \\
\text { contract }\end{array}$ & $\begin{array}{l}\text { Eelationeel } \\
\text { contract }\end{array}$ & $\begin{array}{l}\text { F hierarchie; } \\
\text { relationeel } \\
\text { contract }\end{array}$ \\
\hline
\end{tabular}

Tabel v.2; Overzicht van transactietypen en meest gewenste contractvorm (Williamson)

TCE indiceert dus een neo klassieke contractering voor de meeste bouwwerken. In de praktijk wordt echter erg vaak gebruik gemaakt van

klassieke contracten waarbij gepoogd wordt 'alles' te voorzien en dicht te timmeren. Dit verhoogt transactiekosten, juridificeert aanbestedingen en nodigt uit de stukken met de 'stofkam' te bestuderen met het oog op het veilig stellen van de eigen belangen. Ter illustratie hier een passage die voor zich spreekt als het gaat om neo-klassiek en relationeel contracteren. Mr. ir. J.K. de Schipper schrijft hierover in recht.nl (no. 10-2007):

"De constructieve houding van partijen in de contractuele fase-waarvoor de basis gelegd wordt in de pre contractuele fase- lijkt daardoor een belangrijke succesfactor om te komen tot een voor beide partijen optimaal eindresultaat". "De concrete toepassing van de bovengenoemde oplossingen (neo klassiek en/of relationeel contracteren, $J v D$ ) is hoofdzakelijk voorbehouden aan de opdrachtgevers. De opdrachtgever is immers in het (aanbestedings)proces de dominante partij. Als opdrachtgevers hun aanbestedings en contracteringsbeleid mede inrichten op het opstellen van faire en evenwichtige contract- en aanbestedingsstukken, kan daar- 
mee een bijdrage worden geleverd aan het verkleinen van de onbalans tussen de opdrachtgever en de potentiële gegadigden. De uiteindelijke opdrachtnemer is hierdoor beter geïnformeerd en heeft daarmee meer zicht op een reëel contract. Dat dit ook voor de opdrachtgever wenselijk is, lijkt evident. Er zijn door de opdrachtnemer immers minder "verliezen" goed te maken en daarmee minder prikkels die strategisch (opportunistisch, JvD) gedrag stimuleren."

Turner (2004) geeft aan dat contracten een omgeving moeten creëren die gericht is op samenwerken waarbij de belangen van opdrachtgever en opdrachtnemer in elkaars verlengde liggen en beiden gediend worden. Daartoe zouden contracten stimuli moeten bevatten om in goede samenwerking projectdoelen te realiseren. Dagenais (2007) noemt dit de nieuwe contract moraliteit en geeft aan dat deze op meer vertrouwen is gebaseerd. In deze nieuwe moraliteit worden contractpartijen meer als partners gezien, wordt de inhoud van contracten als minder statisch (meer flexibel) gezien en existeert een contract niet in een vacuüm, maar interfereert het met haar omgeving. Dagenais stelt tevens dat partijen er beter aan doen conflicterende arbitrage methodes te mijden en in te zetten op preventieve benaderingen waarbij vertrouwen (de nieuwe moraliteit) centraal staat.

Coase maakte duidelijk dat markten niet vlekkeloos en niet kosteloos werken (zie ook Bremer, 2004). Er bestaan in tegenstelling tot de uitgangspunten van de klassieke theorieën wel degelijk wrijvingen. Transactiekosten worden vergeleken met fricties in fysieke systemen. Natuurkundigen hebben dit fenomeen grondig onderzocht in laboratoria en hadden een 'taal' om deze fricties te benoemen: wrijving, weestand, warmte etc. Economen ontbeerden een laboratoriumomgeving en beschikten niet over een dergelijke taal. Maar de metafoor van een geoliede machine die een hoog rendement genereert, en binnen de opgegeven marges produceert, laat zich vrij eenvoudig vertalen naar de samenwerkingssituaties bij een bouwproject.

Ook Simon borduurde voort op de TCE basis die Coase (1937) gelegd had. Hij betoogde dat de "homo economicus" (volledig geïnformeerd en in staat nutsmaximalisatie te berekenen) een fictie is uit de neo klassieke economie. Neo klassieke economie veronderstelt dat de mens onbeperkt rationeel en niet opportunistisch is. Stomp (2004) maakt daarbij het onderscheid tussen pre- en postcontractueel opportunisme: adverse selection (het vraagstuk van de selectie van de meest gerede partij) en moral hazard (het vraagstuk van het voorkomen van opportunistisch gedrag na gunning)

Principal agent theory

Kaplan (1995) beschrijft drie sturingsmechanismen

${ }^{n r} 1$ Control by persuasion; sturing d.m.v. overdragen informatie en overreding

$n r 2$ Control by incentives; sturing d.m.v. financiële prikkels

${ }^{n r} 3$ Control by directives and authority; sturing d.m.v. regels en voorschriften

Aannemers hebben vaak meer belang bij continueren van de relatie me de opdrachtgever dan bij de te behalen winst op dat ene project. De motivatie tot het leveren van goede prestaties, het goed samenwerken, het flexibel opstellen etc. ligt dan ook vaak in het zogenaamde opH (Over de Projecten Heen) principe. Dorée benoemt in zijn proefschrift (1996) dit OPH fenomeen voor het eerst. Dorée verbindt er twee conclusies aan

${ }^{n r} \mathbf{1}$ "aannemers streven continue relaties na.

$n r 2$ In continue relaties hebben aannemers minder neiging tot opportunistisch handelen, gedragen aannemers zich coulante en flexibeler jegens opdrachtgevers, zijn aannemers meer gemotiveerd tot het leveren van kwaliteit, speelt wederzijds vertrouwen een belangrijke rol en kan worden volstaan met minder toezicht".

Stomp schrijft daarover in zijn eerder aangehaalde artikel "Het aanbestedingsbeleid uit de schaduw":

“...Het OPH-mechanisme kan worden beschouwd als motivatie methode 
zoals noodzakelijk wordt geacht in de agency theorie om opportunisme te voorkomen. Dit mechanisme werkt als beheersingsmethode omdat het gedrag van de aannemer wordt beïnvloed. De basis van deze

beheersingsmethode wordt gevormd door de keuzevrijheid van de opdrachtgever en de bekendheid met het feit dat hij vaker vergelijkbare diensten/producten nodig heeft..."

Bonding en monitoring costs spelen zowel aan de zijde van de principal als bij de agent. Een agent die liever weinig monitoring ondergaat, zal moeten investeren in goede reputatie en dus veel bonding costs moeten maken.

- Monitoring Costs: zijn alle kosten die de principaal zich getroost om het gedrag van de agent in de gewenste richting te sturen

- Bonding costs: zijn alle kosten die de agent maakt om de principaal te overtuigen dat hij in zijn belang werkt en geen activiteiten zal ontplooien of nalaten die dat belang mogelijk kunnen schaden.

Monitoring and bonding costs werken min of meer als communicerende vaten. Door te investeren in kwaliteitszorg (bonding) kunnen kosten van toezicht (monitoring) dalen. Bij communicerende vaten blijft het totale volume gelijk, de verdeling van die volumina over de beide vaten varieert wel. Bij transactiekosten varieert echter ook de absolute hoogte ervan. De uitdaging is dus een optimum te vinden (voor wat betreft de absolute hoogte van de transactiekosten) waarbij bonding en monitoring costs zich zodanig tot elkaar verhouden dat opdrachtgever en opdrachtnemer dit beiden als een rechtvaardige en constructieve afspiegeling van hun samenwerkingsverhouding ervaren.

\section{Algemeen}

In het Journal of Managerial and Decision Economics (Kim \& Mahomey, 2005) is in het hiernaast afgebeelde overzicht opgenomen dat inzicht geeft in overlappingen en verschillen in de drie theorieën.
Agent theory

Unit of analysis

Principal - agent contract

Focal dimension

Incentives

(alignment agent

- principal)

Focal cost concern Residual loss

Contractual focus Ex ante incentive alignment,

monitoring

mechanisms

Theoretical

orientation

Strategic intent

Sources of

market frictions

Constrained

optimalization

Shareholdersview

Information

asymmetry,

unobservability,

risk aversion (by

agents)

\section{Property rights}

theory

Institution

Property rights

Externalities, ren seeking

Ex ante propertyrights allocation, Ex post distributional conflicts

Comparative assessment

Stakeholdersview

Externalities, unclearly defined

and difficult to enforce property rights, vested

interests
Transaction costs

theory

Transaction

Asset speficicity

Maladaptation, Holdup problems

Choise of (ex post) governance mechanism

Comparative

assessment

Shareholdersview

Boundend

rationality,

uncertainty,

information

asymmetry,

opportunism, asset specificity

Tabel v.3; Overzicht raakvlakken en overlappingen TCE theorieën. Bron: Kim \& Mahony 
Bijlage VI

PiPS versus NIE

Invloed op transactiekosten

\begin{tabular}{|c|c|c|c|c|}
\hline $\begin{array}{r}\text { PiPS } \\
\text { aspect }\end{array}$ & onderdeel & $\begin{array}{l}\text { Invloed op het } \\
\text { reduceren van } \\
\text { onzekerheid }\end{array}$ & $\begin{array}{l}\text { Invloed op } \\
\text { opportunis- } \\
\text { tisch gedrag }\end{array}$ & $\begin{array}{l}\text { Invloed op het } \\
\text { omgaan met } \\
\text { begrensde } \\
\text { rationaliteit }\end{array}$ \\
\hline \multirow[t]{4}{*}{ 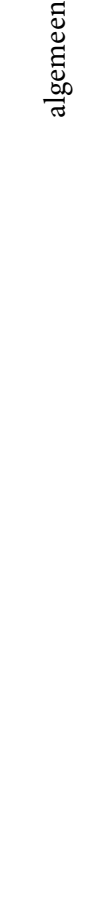 } & $\begin{array}{l}\text { pips filters zijn gericht op } \\
\text { het systematisch vergroten } \\
\text { van de voorspellende waarde } \\
\text { van het selectieproces. Dit } \\
\text { verkleint marktonzekerheid } \\
\text { en transactieonzekerheid. }\end{array}$ & ++ & $\mathrm{o}$ & + \\
\hline & $\begin{array}{l}\text { pips selecteert vooral op } \\
\text { performance. Daardoor } \\
\text { krijgen aannemers de moge- } \\
\text { lijkheid een gezonde marge } \\
\text { te maken. }\end{array}$ & + & ++ & o \\
\hline & $\begin{array}{l}\text { pips is gefocused op efficiënt } \\
\text { verlopend proces; zowel ex } \\
\text { ante als ex post. Alleen in- } \\
\text { formatie die onderscheidend } \\
\text { vermogen oplevert wordt } \\
\text { in ogenschouw genomen. }\end{array}$ & o & + & ++ \\
\hline & $\begin{array}{l}\text { pips bevordert het nadenken } \\
\text { over benodigde functiona- } \\
\text { liteiten en verkleint daarmee } \\
\text { de 'behoeften-onzekerheid'. }\end{array}$ & ++ & ++ & o \\
\hline
\end{tabular}


pips is een rationeel proces. Maakt zaken meetbaar.

Maakt dat de focus op

essenties is gericht.

pips biedt inschrijvers de ruimte met oplossingen

voor gevraagde functionaliteiten te komen i.p.v. sec het afprijzen van reeds uitgedetailleerde projecten.

Inschrijvers voelen zich uitgedaagd wanneer ze gevraagd wordt voor een

bekend budget maximale

value for money te leveren.

pips voorkomt het stellen van disproportionele eisen; inschrijvers kwalificeren

zichzelf door meer en/of

betere PPI, RAP's, sleutel-

functionarissen, prijs in te

zetten

Hanteren van PPI helpt om partij te selecteren die met grote kans op succes (voorspelbaarheid) het project op tijd, binnen budget en naar tevredenheid oplevert.

pips assesst sleutelfunctio-

narissen vanwege stempel

dat ze op het project en de

samenwerking drukken.

Hierdoor worden projectlei-

ders uit de anonimiteit

gehaald en raken ze vroeg

betrokken.

Doordat kwaliteit van

sleutelfunctionarissen als selectiecriterium meeweegt,

zijn inschrijvers geneigd

beste staf naar voren te

schuiven, in tegenstelling

tot handelwijze bij laagste

prijsmechanisme.

Doordat inschrijvers na-

denken over risico's en hoe

die te managen, wordt onze-

kerheid gereduceerd en kan gericht opgetreden worden wanneer risico's zich

voordoen.

$\approx$ Aanbieders kunnen zich

primair onderscheiden op kwaliteit, daarnaast ook op prijs.

تृ Risicoverdeling en overige openstaande punten worden transparant besproken en vastgelegd. Reduceert onzekerheid en zorgt voor alignment of goals.

Reduceert tevens informatie asymmetrie. 


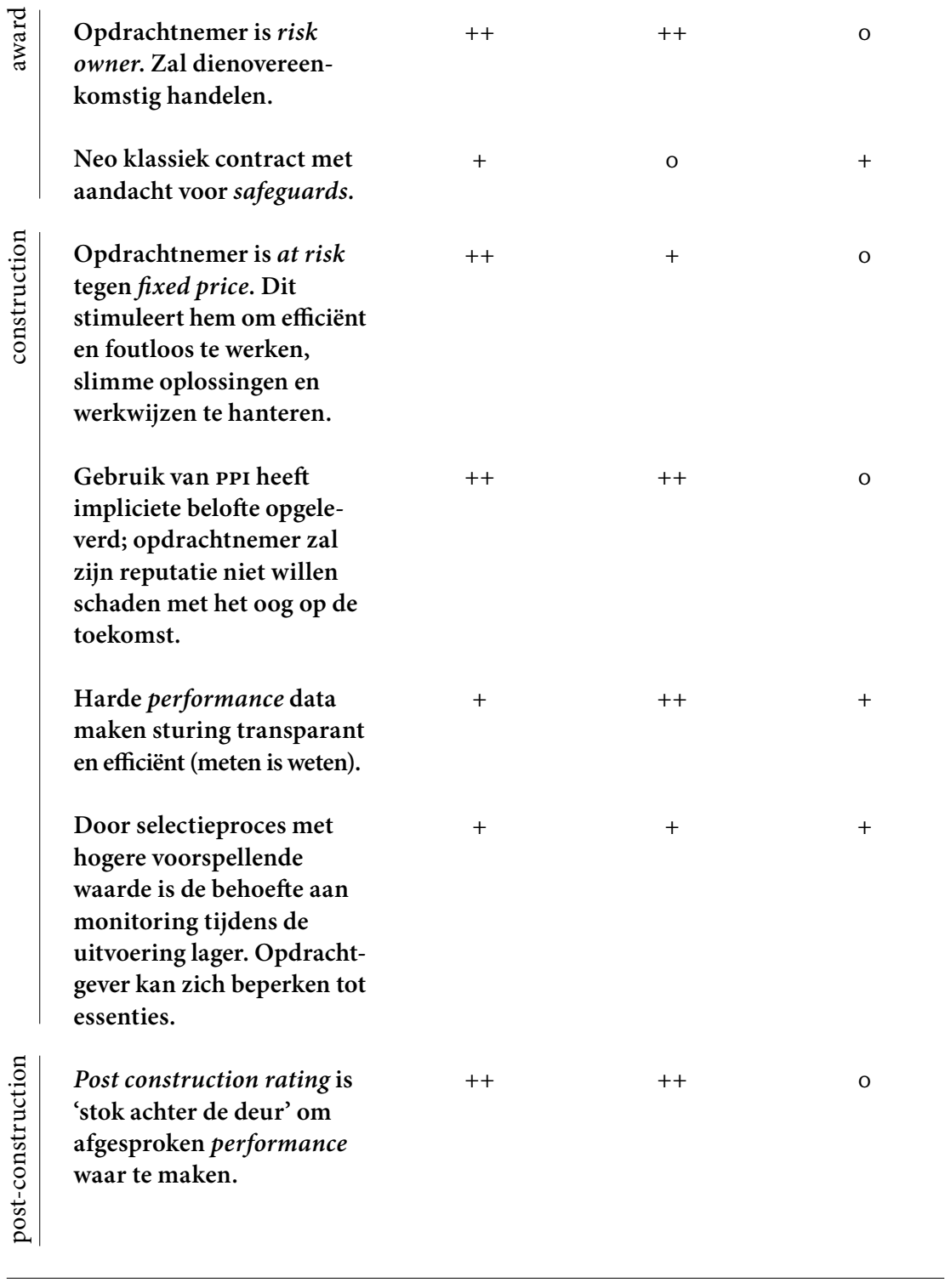

Behalve invloed op de transactiekosten, heeft pips ook invloed op de directe projectgebonden kosten. Het gaat er immers om dat de optelsom van de direct projectgebonden kosten en de transactiekosten zo laag mogelijk is. In onderstaande tabel wordt per pips filter aangegeven welke impact toepassing van dat filter kan hebben op de directe projectgebonden kosten.

Invloed op directe projectkosten

mechanisme effect

षี Opdrachtgever en opdrachtnemer moeten het toepassen van innovatieve elementen leren. Dat vraagt tijd, aandacht en energie. Het is belangrijk dat betrokkenen het hoe en waarom achter de innovatieve elementen begrijpen opdat ze deze adequaat kunnen hanteren. Dit vereist dus een extra investering.

ڤั Maakt mogelijk dat inschrijvers nieuwe (innovatieve) toepassingen, werkwijzen, materialen, detailleringen inbrengen op basis van hun meest recente ervaringen. Door deze inbreng van de markt kunnen effectievere en efficiëntere oplossingen worden ingebracht.

Door het hanteren van een functionele scope ervaren inschrijvers ruimte om het project naar hun hand te kunnen zetten en voelen ze zich uitgedaagd. Er wordt een appèl op hun vakmanschap gedaan. Hen wordt gevraagd met een oplossing te komen die zoveel mogelijk value for money biedt. Tevens worden ze veel vroeger bij het project betrokken. Deze aanpak kan in tegenstelling tot de traditionele versnipperde en volgtijdige aanpak tot kostenreducties leiden. 
Wanneer inschrijvers op basis van een functionele scope gevraagd wordt een oplossing aan te dragen voor het realiseren én het beheren/onderhouden van het project, zal de LCC oriëntatie zorgdragen voor oplossingen die over de gehele levenscyclus gezien een optimum bieden voor wat betreft initiële- en exploitatie kosten.

Wanneer inschrijvers het maximale budget kennen en weten dat ze met een oplossing moeten komen die daarbinnen past en tegelijkertijd veel waarde biedt (in vergelijking met oplossingen waa concurrenten komen), verkleint dat de kans op ongeldige inschrijvingen.

空 Het binnen budget en binnen de planning naar tevredenheid kunnen realiseren van in het verleden uitgevoerde projecten is een belangrijk PPI aspect. Die Past Performance Informatie biedt geen garantie voor het onderhavige project, maar vergroot wel de voorspelbaarheid en daarmee de kans dat de geselecteerde aannemer het onderhavige project zonder overschrijdingen van het budget (overschrijdingen die het gevolg zijn van initiatieven van opdrachtgevers zijde buiten beschouwing latend) en tijdig, naar tevredenheid op zal leveren.

De Pips interviews helpen een partij te selecteren die competent sleutelfunctionarissen in zal zetten. Dat vertaalt zich in projectbeheersing, vakmanschap, een meedenkende en oplossingsgerichte houding. In de praktijk (en ook uit onderzoek) is meermaals gebleken dat er een duidelijke relatie bestaat tussen de projectmanagementcapaciteiten van sleutelfunctionarissen en het beheersen van budgetten, planningen (overschrijden daarvan laat zich bijna altijd kapitaliseren in de vorm van extra kosten) en last but not least kwaliteit (waarde)
Goed en tijdig inzicht in te verwachten risico's en adequate remedies daarvoor laat zich vertalen in minder faal en herstelkosten, minder verloren tijd, kortom een effectiever en efficiënter procesverloop.

PIPS gaat niet voor 'laagste prijs' maar voor zoveel mogelijk waarde binnen een beschikbaar budget. Bij projecten die op laagste prij zijn gegund, treden in de praktijk vele discussies op over meerwerk, wordt opportunistisch gedrag als het ware uitgelokt. Aan het einde van de rit is de opdrachtgever daardoor vaak duurder uit, terwijl tegelijkertijd de waarde die het gerealiseerde project heeft juist lager uitvalt dan gedacht. Pips projecten laten een betere budgetdiscipline zien, prettiger samenwerking, belangen die meer in elkaars verlengde liggen dan tegengesteld zijn. Opdrachtgevers zijn significant meer tevreden met het eindresultaat. pips projecten kennen dus een betere prijs/kwaliteit verhouding.

Door de risicoverdeling volledig transparant en voor beide partijen acceptabel uit te werken kunnen opdrachtgever en opdrachtnemer zich niet verschuilen achter onduidelijkheden, aannames of onuitgesproken verwachtingen (ik dacht dat jij....). Daarin liggen in de praktijk veel oorzaken voor samenwerkingsfricties, (meerwerk)discussies en (dreigende) geschillen. Deze zaken werken in de regel altijd kostenverhogend.

Risico's worden overgedragen zoals besproken. Aannemer zal zijn risico's managen, want dat is direct in zijn belang (zie property rights theorie). Dit zal effect hebben op opleverniveau, faal en herstelkosten, tijdige oplevering. Heldere demarcatielijnen maken dat er weinig 'ruis' hoeft over te blijven hetgeen in de praktijk tot lagere kosten leidt. 
Aannemer heeft er belang bij efficiënt te werken, voorkomen van fouten, aandragen van oplossingen in plaats van problemen. Er is harde performance info beschikbaar die het volgen van het project op hoofdlijnen mogelijk maakt. Het RAP werpt zijn vruchten af; voor zich voordoende problemen zijn mogelijk al oplossingen voorhanden. De aannemer heeft het project naar zijn hand kunnen zetten, is al in een vroeg stadium betrokken, weet dat ie een gezonde marge kan maken, heeft ingestemd met de risico verdeling. Dat alles draagt bij aan het opleveren binnen budget en planning en naar (kwaliteits)tevredenheid van de opdrachtnemer.

Totale performance niveau is rechtevenredig met de kans op toekomstig werk. Vanwege dit zogenaamde OPH effect zal aannemer coulant en coöperatief zijn. Dat vertaalt zich in betere kostenbeheersing.
Tabel vi.2; Invloed van pips elementen op directe projectkosten

Wanneer we de pips variabelen aldus in verband brengen met de transactiekosten en de directe projectgebonden kosten, zien we dat pips in alle gevallen een reducerende werking heeft op het kostenniveau. Uitzondering wordt gevormd door de kosten die een organisatie moet maken om innovatieve elementen op een goede wijze toe te passen bij het voorbereiden, aanbesteden en realiseren van projecten. Het is dus zaak dat deze kosten in verhouding staan tot de projectbelangen en de te verwachten meerwaarde van innovatief aanbesteden.

Zoals hiervoor te lezen valt bij de ervaringen met de praktijkcases (hoofdstuk 5), is de investering in het leren werken met innovatieve elementen al snel lonend.

\section{Welke effecten hebben pips safeguards volgens opdrachtgevers} op hun eigen onzekerheid?

$\begin{array}{llllll}\text { Meer } & \begin{array}{l}\text { Behoefte } \\ \text { onzekerh. }\end{array} & \begin{array}{l}\text { Contract } \\ \text { onzekerh. }\end{array} & \begin{array}{l}\text { Onvoor- } \\ \text { ziene } \\ \text { info? }\end{array} & \begin{array}{l}\text { Extra } \\ \text { inspann. }\end{array} & \begin{array}{l}\text { Ver- } \\ \text { trouwen }\end{array}\end{array}$

Funcspec

Bijlage VII

PiPs safeguards versus onzekerheid en opportunisme

Safeguards versus onzekerheid Opdrachtgevers; in te vullen door opdrachtgevers.

Reduceert het gebruik van pips safeguards onzekerheid voor opdrachtgevers, volgens opdrachtgevers?

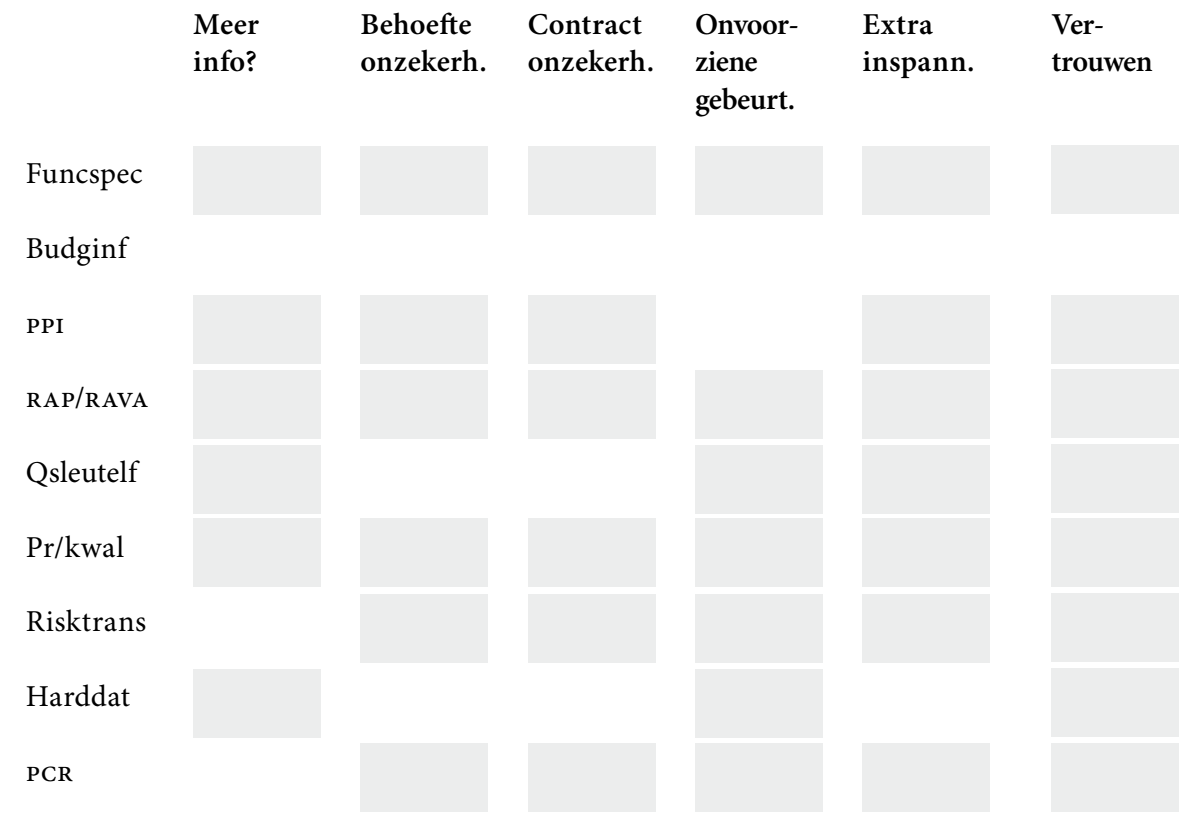

Tabel viI.1; Confrontaties piPs safeguards met onzekerheid opdrachtgevers 
NB: Confrontaties die niet vertaald zijn naar een statement in deze online-enqûete:

- Zijn confrontaties waarvan geen of een te gering verband verondersteld wordt

- Dragen niet bij aan de justificatie van de theoretische redeneringen

- Vertonen (te) veel overlap met statements die wel opgenomen zijn

- Zijn in onvoldoende mate te vertalen naar een helder statement

Verantwoording:

- Omtrent Budgetinf zijn geen stellingen opgenomen m.b.t. onzekerheid omdat dit informatie is die de opdrachtgever toch al heeft, los van de vraag of hij deze info deelt met inschrijvers. Het reduceert zijn onzekerheid m.b.t. de operationalisaties dan ook niet

- Omtrent PPI en onvoorziene gebeurtenissen is geen stelling opgenomen omdat informatie hieromtrent uit het verleden niet maatgevend hoeft te zijn voor zich in de toekomst voordoende onvoorziene gebeurtenissen

- Omtrent Qsleutelf en behoefte onzekerheid is geen stelling opgenomen omdat de behoeften al geformuleerd zijn voordat er zicht komt op de kwaliteit van in te zetten sleutelfunctionarissen

- Omtrent Qsleutelf en contractonzekerheid is geen stelling geformuleerd omdat de invloed van de kwaliteit van de sleutelfunctionaris op contractonzekerheid marginaal wordt verondersteld

- Omtrent Risktrans en 'meer info' is geen stelling geformuleerd omdat tussen deze zaken geen relatie wordt verondersteld

- Omtrent Harddat en behoefte onzekerheid is geen stelling geformuleerd omdat behoefte onzekerheid zich meer in het begin van het aanbestedingsproces manifesteert en Harddat pas na gunning

- Omtrent Harddat en contractonzekerheid is geen stelling geformuleerd omdat er geen duidelijk verband verondersteld wordt tussen beide zaken; je kunt immers goed over de performance geïnformeerd worden zonder dat je krijgt wat je beoogt

- Omtrent Harddat en 'extra inspannngen' is geen stelling geformuleerd omdat verondersteld wordt dat het beschikken over performance data van geringe invloed is op de bereidheid extra inspanningen te leveren

- Omtrent PCR en 'meer info' is geen stelling geformuleerd omdat de overige operationalisaties dit al afdekken.
Safeguards versus opportunistisch gedrag opdrachtnemers; in te vullen door opdrachtgevers:

Ontmoedigt het gebruik van pips safeguards opportunistisch gedrag van opdrachtnemers volgens opdrachtgevers?

\section{Welke effecten hebben pips safeguards volgens opdrachtgevers} op opportunistisch gedrag van opdrachtnemers?

\begin{tabular}{|c|c|c|c|}
\hline drag & $\begin{array}{l}\text { Onvold. } \\
\text { Vakmans }\end{array}$ & $\begin{array}{l}\text { Star \& } \\
\text { onredelijl }\end{array}$ & $\begin{array}{l}\text { Geen } \\
\text { coulance }\end{array}$ \\
\hline
\end{tabular}

Funcspec

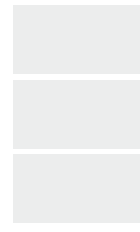

PPI

RAP/RAVA

Qsleutelf

Pr/kwal

Risktrans

Harddat
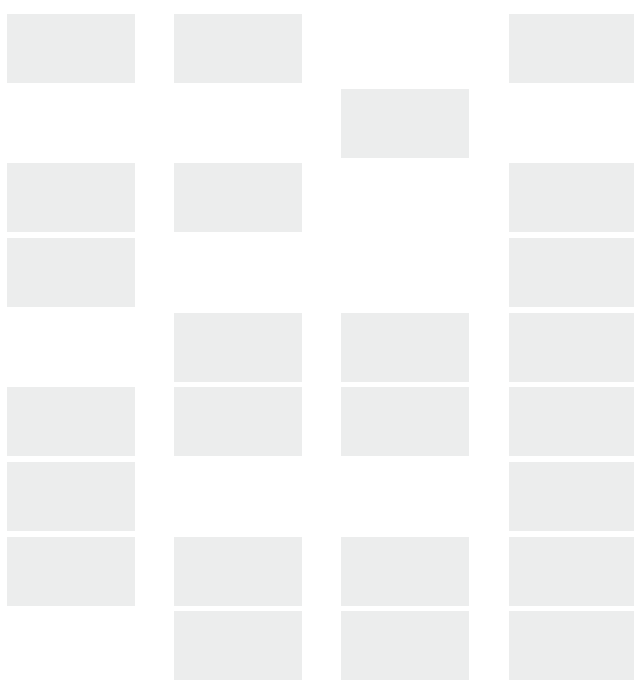
Gaten

Duiken \&

uitspelen

graaien

Funcspec

Budginf

PPI

RAP/RAVA

Qsleutelf

Pr/kwal

Risktrans

Harddat

PCR

Tabel viI.2; Confrontaties PiPs safeguards met opportunisme opdrachtnemers

\section{Verantwoording:}

- Algemeen: we hebben hier te maken met 8 operationalisaties van opportunistisch gedrag. In het algemeen wordt aanbevolen matrixvragen (zonder subkopjes) hooguit uit zes subvragen te laten bestaan. Om deze reden zijn hier keuzes gemaakt en een aantal confrontaties niet terug te vinden in de enquête. Bij die keuzes is leidend geweest dat voorrang is gegeven aan confrontaties waarbij duidelijker verbanden zijn voorondersteld.

NB: Confrontaties die niet vertaald zijn naar een statement in deze online-enqûete:

- Zijn confrontaties waarvan geen of een tegring verband verondersteld wordt

- Dragen niet bij aan de justificatie van de theoretische redeneringen

- Vertonen (te) veel overlap met statements die wel opgenomen zijn

- Zijn in onvoldoende mate te vertalen naar een helder statement 
Safeguards versus onzekerheid opdrachtnemers; in te vullen door opdrachtnemers:

Reduceert het gebruik van pips safeguards onzekerheid voor opdrachtnemers, volgens opdrachtnemers?

Welke effecten hebben pips safeguards volgens opdrachtnemers op hun eigen onzekerheid?

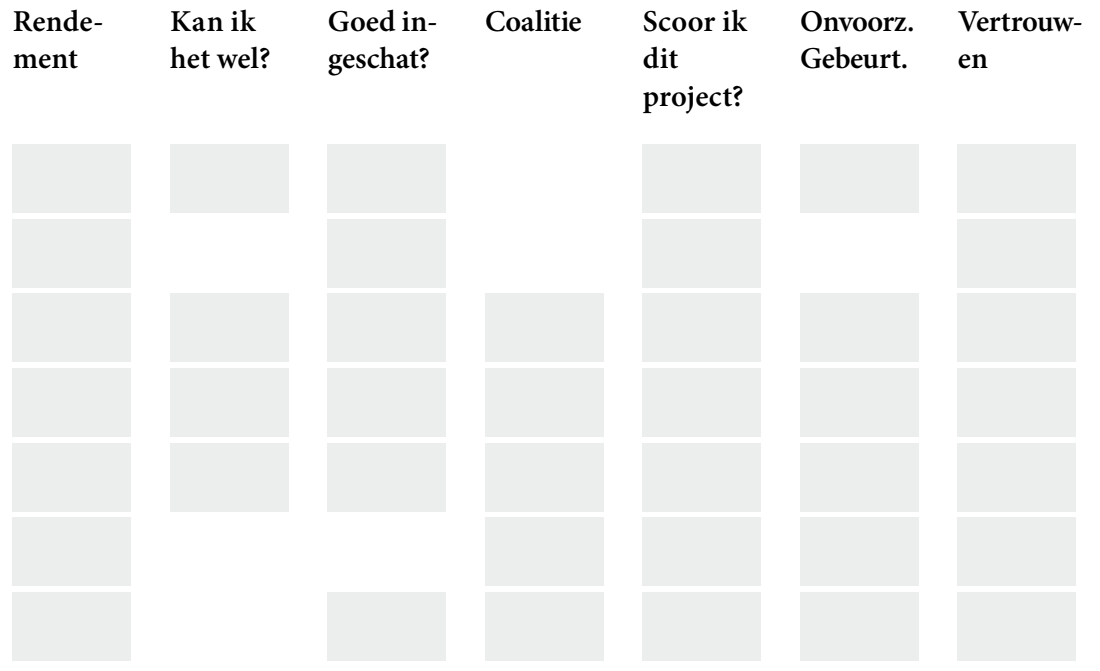

Harddat

PCR
NB: Confrontaties die niet vertaald zijn naar een statement in deze online-enqûete:

- Zijn confrontaties waarvan geen of een te gering verband verondersteld wordt

- Dragen niet bij aan de justificatie van de theoretische redeneringen

- Vertonen (te) veel overlap met statements die wel opgenomen zijn

- Zijn in onvoldoende mate te vertalen naar een helder statement

\section{Verantwoording:}

- Algemeen: we hebben hier te maken met zeven operationalisaties. In tegenstelling tot de vorige matrix is er hier voor gekozen bij drie safeguards alle zeven de confrontaties op te nemen vanwege de vooronderstelde duidelijke verbanden.

- Bij Harddat en PCR zijn geen stellingen geformuleerd omdat te geringe verbanden voorzien worden tussen deze safeguards en de operationalisaties.

- Omtrent Funcspec en 'coalitie' is geen stelling geformuleerd omdat een te gering verband wordt voorondersteld tussen deze zaken

- Datzelfde geldt voor de 3 ontbrekende confrontaties van de safeguard Budginf en voor de bij Risktrans ontbrekende confrontatie met 'kan ik het wel?'

- Ook voor wat betreft $\mathrm{Pr} / \mathrm{kwal}$ geldt dat met betrekking tot ' $\mathrm{kan}$ ik het wel' en 'goed ingeschat' een te gering verband wordt voorondersteld om er een stelling van te maken.

Tabel VII.3; Confrontaties PiPs safeguards met onzekerheid opdrachtnemers 
Safeguards versus opportunistisch gedrag opdrachtgevers; in te vullen door opdrachtnemers:

Ontmoedigt het gebruik van pips safeguards opportunistisch gedrag van opdrachtgevers, volgens opdrachtnemers?

\section{Welke effecten hebben pips safeguards volgens opdrachtnemers}

op opportunistisch gedrag van opdrachtgevers?

$\begin{array}{lllll}\begin{array}{l}\text { Info } \\ \text { Achterh. }\end{array} & \text { Prijsklem } & \begin{array}{l}\text { Niet } \\ \text { flexibel }\end{array} & \begin{array}{l}\text { Niet } \\ \text { objectief }\end{array} & \begin{array}{l}\text { Niet } \\ \text { open }\end{array}\end{array}$

Funcspec

Budginf

PPI

RAP/RAVA

Qsleutelf

Pr/kwal

Risktrans

Harddat
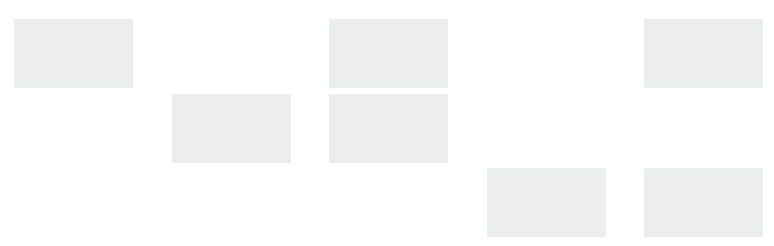

PCR
NB: Confrontaties die niet vertaald zijn naar een statement in deze online-enqûete:

- Zijn confrontaties waarvan geen of een te gering verband verondersteld wordt

- Dragen niet bij aan de justificatie van de theoretische redeneringen

- Vertonen (te) veel overlap met statements die wel opgenomen zijn

- Zijn in onvoldoende mate te vertalen naar een helder statement

Verantwoording:

- Algemeen: Opportunistisch gedrag bij opdrachtgevers is in de literatuur minder uitgewerkt dan aan opdrachtnemerskant. Dat maakte het lastiger de op basis van het literatuur onderzoek gevonden operationalisaties te vertalen naar stellingen op bais van de confrontatie met de safeguards

- Het wel/niet hanteren van RAP/RAVA, Harddat en PCR zal naar voorondersteld wordt niet veel impact hebben op de vraag of en in welke mate de opdrachtgever zich opportunistisch zal gaan gedragen; vandaar dat voor deze drie safeguards geen stellingen zijn opgenomen

- Voor de overige safeguards geldt dat alleen die stellingen zijn opgenomen waarvan voorondersteld wordt dat ze duidelijke verbanden bevatten tussen safeguards en operationalisaties van opportunistisch gedrag door de opdrachtgever

Tabel vir.4; Confrontaties pips safeguards met opportunisme opdrachtgevers. 
Inleiding ${ }^{15}$

Het in de markt zetten van een vraagspecificatie dient (ervan uitgaande dat de aanbesteder gehouden is Europees aan te besteden) te geschieden volgens vast omlijnde procedures. Er bestaan verschillende procedures. De keuze voor een bepaalde procedure kan niet geheel vrijelijk worden gemaakt. Bovendien past de ene procedure beter bij een bepaald project en bij voor dat project gemaakte keuzes omtrent bouworganisatievorm, vraagspecificatie en contractvorm.

Een aanbestedingsprocedure is een procedure met behulp waarvan een aanbesteder wil komen tot gunning van een opdracht aan een marktpartij, door daarbij een zekere mate van concurrentie op te roepen.

Bovenstaande houdt in dat pas van een aanbestedingsprocedure gesproken kan worden als de aanbesteder minstens twee marktpartijen tegelijkertijd benadert, met een uitnodiging tot deelname, en als deze marktpartijen ook op de hoogte zijn van het feit dat ze deelnemen aan een door de aanbesteder georganiseerde competitie. Het besef dat deelnemers in competitie tegelijkertijd met andere deelnemers dingen naar een opdracht is hierbij essentieel. Marktpartijen die aan een dergelijke procedure deelnemen, mogen ervan uitgaan dat de aanbesteder de procedure zodanig inricht en volgt, dat deelnemers gelijke kansen hebben om de opdracht te verwerven. Dit betekent dat een aanbesteder die eenmaal een aanbestedingsprocedure is gestart, niet meer geheel vrij is om naar eigen inzicht tot de keuze van een partij te komen aan wie het werk gegund zal worden. Hij zal de deelnemers op gelijke en niet discriminerende wijze moeten behandelen en de procedure tegen die achtergrond moeten inrichten en hanteren.

De beschikbare procedures verschillen nogal van elkaar, vandaar dat een bewuste en weloverwogen keuze voor een bepaalde procedure van groot belang is. Voor elke aanbesteding geldt dat de aanbestedende partij tegen zo laag mogelijke (totaal)kosten zal willen voorzien in de beoogde functionaliteiten. De belangrijkste verschillen zitten in de bekendmaking van de aanbestedingsprocedures. Er zijn procedures waarbij algemene bekendmaking achterweg kan blijven, anderen vragen
${ }^{115}$ De tekst van deze bijlage is gebaseerd op het consultatiedocument "Leidraad aanbesteden voor de bouw" onder eindredactie van prof. mr. dr. C.E.C

Jansen, vu

Amsterdam. 
juist om openbare bekendmaking. Bij algemene bekendmaking zijn transactiekosten in het algemeen hoger, maar aan de andere kant wordt het mededingingsbelang door deze procedure beter gediend dan door de andere procedures. Een ander belangrijk verschil zit in de mate waarin de verschillende procedures ruimte bieden om informatie uit te wisselen met afzonderlijke deelnemers. Kort gezegd bieden de concurrentiegerichte dialoog en de onderhandelingsprocedure daartoe (het uitwisselen van informatie) meer mogelijkheden dan de openbare en de niet openbare procedure.

\section{De openbare procedure}

Deze procedure is beschreven in hoofdstuk twee van het ARW. Dit betreft een procedure die algemeen bekendgemaakt moet worden. Alle in de opdracht geïnteresseerde partijen krijgen in beginsel de gelegenheid aan de procedure deel te nemen. Dit geschiedt door het direct doen van een inschrijving. $\mathrm{Na}$ indienen van de inschrijvingen beoordeelt de aanbesteder in één ronde of een inschrijver wordt uitgesloten, of aan geschiktheidseisen wordt voldaan en welke van de inschrijvingen op grond van het gekozen gunningscriterium als beste uit de bus komt. Deze procedure voorziet slechts marginaal in de mogelijkheid om bilateraal informatie uit te wisselen met individuele inschrijvers. Dat zelfde geldt voor ruimte die de aanbesteder heeft om te onderhandelen na ontvangst van de inschrijvingen.

\section{De niet openbare procedure}

Deze procedure is beschreven in hoofdstuk drie van het ARW. Ook deze procedure wordt -anders dan de naam wellicht doet vermoeden- algemeen bekend gemaakt. Alle geïnteresseerde partijen hebben in beginsel de gelegenheid te participeren. Ze melden zich in deze procedure eerst aan als gegadigde. Daarna beoordeelt de aanbesteder of marktpartijen in aanmerking komen uitgenodigd te worden voor het doen van een daadwerkelijke inschrijving. Deze procedure onderscheidt dus een zogenaamde selectiefase en een gunningsfase. De aanbesteder heeft de mogelijkheid vooraf aan te geven met bijvoorbeeld maximaal vijf partijen de gunningsfase in te willen gaan. Aanbesteder heeft dan de plicht gemotiveerd aan te geven welke vijf marktpartijen het meest geschikt zijn gebleken op grond van de vooraf bekend gemaakte selectiecriteria. Na ontvangst van de daadwerkelijke inschrijvingen volgt een tweede beoordelingsronde waarin bepaald wordt welke in schrijver -op grond van het vooraf bekend gemaakte gunningscriterium- als beste uit de bus komt. Ook bij deze procedure is bilaterale informatie uitwisseling slechts in begrensde mate mogelijk. Dat zelfde geldt voor mogelijkheden om na ontvangst van de inschrijvingen met partijen te onderhandelen.

\section{De concurrentiegerichte dialoog}

Deze procedure wordt geregeld in hoofdstuk vier van het ARW 2005. Het eerste stuk (de selectie van geschikte partijen) van deze procedure verloopt identiek aan de niet openbare procedure. Daarna worden de meest geschikte gegadigden uitgenodigd tot deelname aan een bilaterale dialoog ${ }^{116}$ met de aanbesteder. Doel van deze dialogen is dat de aan besteder probeert na te gaan welke oplossingen die bij de verschillende gegadigden voorhanden zijn het meest geschikt zijn om te voorzien in zijn vraag. De concurrentiegerichte dialoog kan niet zomaar voor elk project worden gekozen. Deze procedure is alleen toegestaan voor projecten die zodanig complex zijn dat de aanbesteder redelijkerwij niet in staat geacht kan worden om alleen (lees zonder de knowhow van marktpartijen) zijn vraag afdoende te kunnen specificeren en/o de financiële en/of juridische randvoorwaarden te kunnen bepalen. Wanneer geïntegreerde contractvormen als DBFM en DBFMO worden gehanteerd, wordt aan deze voorwaarden voldaan en mag deze procedure worden gevolgd.

Bij de dialogen mag gesproken worden over alle aspecten van het betreffende project. Wel moet de aanbesteder ervoor waken dat het verstrekken van discriminerende informatie aan één of meer gegadigden niet is toegestaan. De aanbesteder kan tijdens de dialoogronde aan gegadigden vragen hun oplossingen nader uit te werken. Deze uitgewerkte oplossingen worden door de aanbesteder beoordeeld aan de hand van het vooraf bekend gemaakte gunningscriterium waarbij bepaalde oplossingen afvallen. Daarna nodigt de aanbesteder de gegadigden wiens oplossingen niet zijn afgevallen uit tot het doen van een inschrijving. Deze inschrijvingen worden vervolgens weer beoordeeld, aan de best scorende inschrijver kan worden gegund. De concurrentiegerichte dialoog biedt dus goede mogelijkheden om voorafgaand aan 
de inschrijving bilateraal informatie uit te wisselen. Na ontvangst van de feitelijke inschrijving zijn de onderhandelingsmogelijkheden net zo beperkt als bij de twee hiervoor kort beschreven procedures.

\section{Onderhandelingsprocedure met voorafgaande bekendmaking}

Deze procedure wordt beschreven in hoofdstuk vijf van het ARW 2005.

Deze procedure start met een openbare bekendmaking van de aanbesteding. Ook hierbij verloopt het eerste deel conform de niet openbare procedure en de concurrentiegerichte dialoog. Na de selectiefase nodigt de aanbesteder partijen uit tot het doen van een inschrijving. $\mathrm{Na}$ beoordeling daarvan worden partijen uitgenodigd voor bilaterale onderhandelingen. Doel van die onderhandelingen is dat de aanbesteder probeert met ieder van de inschrijvers de contractuele voorwaarden (nader) vast te stellen. Tijdens het verloop van deze onderhandelingen kan de aanbesteder op basis van het vooraf bekend gemaakte gunningscriterium partijen laten afvallen. De onderhandelingen kunnen per inschrijver over verschillende aspecten gaan en kunnen dientengevolge ook wisselend verlopen, zowel qua inhoud als qua planning. De aanbesteder moet er wel voor waken dat geen discriminerende informatie aan één of meerdere partijen wordt versterkt. Aanbesteders mogen alleen in specifieke situaties voor deze procedure kiezen (als er sprake is van enkel onregelmatige of onaanvaardbare inschrijvingen, als de prijs vooraf niet is vast te stellen, als de opdracht niet nauwkeurig is te specificeren en bij onderzoeksopdrachten).

Onderhandelingsprocedure zonder voorafgaande bekendmaking Bij deze procedure (hoofdstuk zes van ARW 2005) wordt de procedure gestart zonder dat de opdracht algemeen bekend wordt gemaakt. In veel gevallen waarin deze procedure is toegestaan, zal de aanbesteder slechts één marktpartij uitnodigen. Daarmee is er geen sprake van mededinging en is deze procedure eigenlijk niet te kwalificeren als aanbestedingsprocedure (zie definitie tweede alinea van de inleiding van deze bijlage). Na ontvangst van de inschrijving nodigt de aanbesteder de inschrijver uit voor bilaterale onderhandelingen om de contractvoorwaarden (nader) vast te stellen. Aanbesteders mogen deze procedure enkel hanteren als bij de openbare procedure of de niet openbare procedure geen of geen geschikte (onregelmatig of onaanvaardbaar) inschrijvingen zijn binnen gekomen.

\section{Onderhandse procedure}

Deze procedure wordt beschreven in hoofdstuk zeven van het ARW 2005. Opdrachtgevers die aanbestedingsplichtig zijn in het kader van BAO, mogen deze onderhandse procedure niet gebruiken (voor werken onder de drempelbedragen vervalt deze verplichting en mag deze procedure wel worden gehanteerd tenzij de passende mate van openbaarheid zich hiertegen verzet). Bij deze procedure wordt de opdracht niet algemeen bekend gemaakt. De aanbesteder nodigt naar eigen inzicht enkele marktpartijen uit. De aanbesteder heeft vervolgens de vrijheid ofwel in één ronde ofwel in twee rondes (eerst selectie, dan gunning) te bepalen aan wie hij de opdracht zal gunnen. De mogelijkheden om bilateraal informatie uit te wisselen of te onderhandelen zijn bij deze procedure gelijk aan die van de openbare en niet openbare procedures.

\section{Concessieovereenkomst voor openbare werken}

Deze procedure wordt in hoofdstuk acht van het ARW 2005 beschreven. Deze procedure is minder duidelijk als zodanig te herkennen. Er is meer sprake van een set van bepalingen die in hun onderlinge samenhang een aanbestedingsprocedure vormen. De procedure start met een algemene aankondiging van het voornemen tot uitgifte van een concessie. Verder staat het de aanbesteder vrij de procedure in te richten zoals hem dat passend dunkt. Uiteraard dienen daarbij de aanbestedingsbeginselen ten aanzien van transparantie, non-discriminatie en proportionaliteit in acht te worden genomen. Ten aanzien van ruimte om bilateraal informatie uit te wisselen en na ontvangst van inschrij-

vingen daarover te onderhandelen, geldt hetzelfde als voor de openbare en niet openbare procedures.

\section{Raamovereenkomst met een enkele ondernemer}

Hiervan is sprake als een aanbesteder een van de hiervoor besproken procedures aanwendt om te komen tot een raamovereenkomst met één ondernemer. Een raamovereenkomst is in dezen te zien als een overeenkomst die voor een bepaalde periode de voorwaarden regelt op het gebied van te gunnen opdrachten. De procedurevoorschriften 
die in dit verband gelden zijn opgenomen in hoofdstuk negen van het ARW 2005. De aanbesteder beschikt over een zekere ruimte om informatie met de aanbieder uit te wisselen alvorens tot gunning over te gaan.

\section{Raamovereenkomst met meerdere ondernemers}

Een aanbesteder kan een van de hiervoor besproken procedures

gebruiken voor het sluiten van een raamovereenkomst met meerdere ondernemers. Wanneer de aanbesteder vervolgens concrete opdrachten wil gunnen, moet hij een aantal procedurevoorschriften in acht nemen. Afhankelijk van het antwoord op de vraag of de aanbesteder in dat concrete geval opnieuw mededinging haar werk wil laten doen, kunnen er twee procedures worden onderscheiden.

Ten eerste kan de aanbesteder de opdracht direct gunnen aan één van de ondernemers die partij zijn bij de raamovereenkomst. Ten tweede kan de aanbesteder opnieuw tot mededinging oproepen alvorens tot gunning over te gaan. Vooral voor deze tweede mogelijkheid zijn een aantal procedure voorschriften opgenomen in hoofdstuk tien van het ARW 2005. De procedure die in zo een geval wordt gevolgd, vertoont veel overeenkomsten met de onderhandse procedure.

\section{Bijlage IX}

\section{Interviewronde Juristen}

Vragenlijst interviewronde juristen

$n r 1$ Mag je van inschrijvers vragen, oordelen (tevredenheid, bi budget, bi planning) bij voormalig opdrachtgevers op te vragen over past performance en die oordelen mee laten wegen bij de aanbesteding? (Zie ARW 2005 pag 288)

$n r 2$ Mag je inschrijvers die van meer projecten, en van meer relevante en meer omvangrijke projecten PPI inleveren, een hogere score toekennen?

nr 3 Mag je consortia die al bewezen hebben succesvol samen te kunnen werken een hogere PPI score toekennen dan partijen die gezamenlijk inschrijven, maar nog niet eerder samen projecten gerealiseerd hebben?

$n r 4$ Mag je inschrijvers informeren over de hoogte van het beschikbare budget en hen uitdagen zoveel mogelijk value for money te offreren. Mag je daarbij aangeven dat overschrijding van het budget diskwalificatie betekent?

${ }^{n r} 5$ Mag je de kwaliteit, opleiding en vorming van sleutelfunctionarissen mee laten wegen? Mag je deze scores baseren op individuele interviews met medewerkers? Aan welke objectiviteits-eisen moet je dan voldoen?

nr 6 Mag je een overall score (m.b.t. de performance van een aannemer) van een bepaald project mee laten wegen bij de start van een volgende aanbesteding? 
$n r 7 \quad$ Mag de wijze waarop een inschrijver de functionele specs vertaalt naar een concrete oplossing (waarbij hij zijn kennis en ervaring en innovaties inbrengt) meewegen bij de beoordeling in een EU aanbestedingstraject? Moet dergelijke inbreng gezien worden als variant van een inschrijver en wat brengt dat dan met zich mee?

$n r 8$ Mogen de presentaties van de oplossingen van de inschrijvers leiden tot dialogen? Waar ligt hierin de grens?

a. Mogen deze dialogen dienen om interpretatieverschillen te verkleinen c.q. weg te nemen?

b. Mag je de kennis die geëtaleerd wordt tijdens een dergelijke presentatie en dialoog mee laten wegen?

${ }^{n r} 9$ Prof. Wedekind maakt in zijn afscheidsoratie (Te downloaden vanaf $w w w . i b r . n l)$ melding van een dereguleringsslag waaraan de Europese Commissie lijkt te beginnen.

a. Wat zijn verwachtingen hieromtrent, zal de inbreuk op de conracteervrijheid in de toekomst kleiner worden?

b. Op welke punten zal zich dat toespitsen?

c. Is de verwachting dat huidige "spanning" tussen innovatieve elementen en de Eu aanbestedingswet daardoor zal verkleinen?

d. Zo ja, op welke punten?

nr 10 Mag je nieuwkomers afwijzen als ze over onvoldoende PPI beschikken in vergelijking met andere inschrijvers?

nr 11 Mag je volstaan met een globale projectbeschrijving in functionele termen ("realiseren van een stallingsgarage op perceel $x$ voor 800 auto's die voldoet aan alle wettelijke eisen en die past bij de uitstraling van omliggende bebouwing") Zie BAO art. 23 Zie ARW 2005 2.5.2

nr 12 Biedt de experimenteerbepaling (ARW 2005 H11) uit ARW 2005 perspectief? Hoe kun je daar gebruik van maken? Wat zijn de voorwaarden? $n r 13$ Welke andere obstakels zijn er i.r.t. innovatieve elementen versus EU wet en welke oplossingen/remedies zijn in uw ogen mogelijk?

Deze interviewvragen zijn gesteld aan onderstaande personen (weergegeven in alfabetische volgorde):

Ir. N.A. Niels | Amstel, Bouwend Nederland

H. van Baayen | Directeur Kenniscentrum Aanbesteden Bouw

mr. B. van den Berg | Prorail

J. Berns | Adviseur Europa Decentraal

mw. mr. A.A. Boot | Boot Advocaten Amsterdam

mr.A.P.C.F. Doggen | ACA (advies centrum aanbesteding en bouw)

mw. mr. Dr. E.R. Manunza | vu Amsterdam. Universitair Hoofddocent Europees Recht

prof. G.W.A. van de Meent | Loyens Loeff

Tim Robbe $\mid a \delta$ Compendium

mr. dr. H.D. van Romburgh | LNV

mr. M.N. Strijker | Loyens Loeff

mr. D. E. van Werven | Bouwend Nederland 
Bijlage $\mathrm{X}$

Overzicht van BVP projecten door J. van Duren begeleid

\begin{tabular}{|c|c|c|c|c|}
\hline project & jaar & omschrijving & omvang & status \\
\hline umc St R OH1 & 2005 & $\begin{array}{l}\text { Herbekabelen } \\
\text { hoofdverdeelkasten } \\
\text { UMC St. Radboud }\end{array}$ & Ca. 65.000,- & opgeleverd \\
\hline UMC St R OH2 & 2005 & $\begin{array}{l}\text { Vernieuwen stoombe- } \\
\text { vochtiging UMC St. } \\
\text { Radboud }\end{array}$ & Ca. 160.00o,- & opgeleverd \\
\hline UMC St $\mathrm{R} \mathrm{OH}_{3}$ & 2005 & $\begin{array}{l}\text { Vervangen dakbedek- } \\
\text { kingspakket UMC St. } \\
\text { Radboud }\end{array}$ & Ca. 80.000,- & opgeleverd \\
\hline UMC St R parkeer & 2006 & $\begin{array}{l}\text { Nieuwbouw parkeer- } \\
\text { garage UMC St. } \\
\text { Radboud > } 630 \text { pp. }\end{array}$ & 4,2 miljoen & opgeleverd \\
\hline UMC St R fase III & 2007 & $\begin{array}{l}\text { E, w en B aanbest. } \\
\text { nieuwbouw UMC St. } \\
\text { Radboud Fase III }\end{array}$ & Ca. 60 miljoen & opgeleverd \\
\hline Bergbezinkbassin & $\begin{array}{l}2008 / \\
2009\end{array}$ & $\begin{array}{l}\text { Aanleg bergbezink- } \\
\text { bassin gemeente } \\
\text { 's-Hertogenbosch }\end{array}$ & $830.000,-$ & opgeleverd \\
\hline LvR Holzstr & 2010 & $\begin{array}{l}\text { Nieuwbouw } 7 \text { app. + } \\
\text { aanpassen belendingen } \\
\text { Land v. Rode }\end{array}$ & $1.520 .000,-$ & opgeleverd \\
\hline LvR 20 app & 2011 & $\begin{array}{l}\text { Nieuwbouw } 20 \text { zorg } \\
\text { app. Land v. Rode }\end{array}$ & 1.500.000,- & opgeleverd \\
\hline
\end{tabular}




\begin{tabular}{|c|c|c|c|c|}
\hline project & jaar & omschrijving & omvang & status \\
\hline LvR 31 won & 2011 & $\begin{array}{l}\text { Nieuwbouw } 31 \text { woning- } \\
\text { en lage EPC Land van } \\
\text { Rode }\end{array}$ & 4.100.000,- & opgeleverd \\
\hline LvR 12 ENW & 2011 & $\begin{array}{l}\text { Nieuwbouw } 12 \\
\text { energie neutrale } \\
\text { woningen Land v. } \\
\text { Rode }\end{array}$ & Ca. 1.80o.0oo,- & aanbesteed \\
\hline Berg en Terblijt & 2012 & $\begin{array}{l}\text { Nieuwbouw } 28 \\
\text { woningen Langen } \\
\text { Akker }\end{array}$ & Ca. 4.000.000,- & aanbesteed \\
\hline Cicero Pius & 2011 & $\begin{array}{l}\text { Renovatie \& } \\
\text { meerjaren onderhoud } \\
\text { zorgcentrum Pius }\end{array}$ & $4.800 .000,-$ & opgeleverd \\
\hline Cicero OdT & 2011 & $\begin{array}{l}\text { Nieuwbouw Zorgcen- } \\
\text { trum Op den Toren }\end{array}$ & 11 miljoen & aanbesteed \\
\hline Cicero 't Brook & 2012 & $\begin{array}{l}\text { Uitbreiding en } \\
\text { renovatie zorgcen- } \\
\text { trum 't Brook }\end{array}$ & Ca. 7 miljoen & $\begin{array}{l}\text { Onder } \\
\text { handen }\end{array}$ \\
\hline EIPA & 2012 & $\begin{array}{l}\text { Schoonmaakonder- } \\
\text { houd Europees } \\
\text { Instituut }\end{array}$ & Ca. 200.000,- & opgeleverd \\
\hline
\end{tabular}

Tabel X.1; overzicht BVP projecten door J. van Duren begeleid. 
Geef hier aan of $u$ onderstaande aspecten in de praktijk al hebt gehanteerd (al eerder toegepast niet/nauwelijks/regelmatig/veel):

$\square \quad$ Werk aanbesteden op basis van een oplossingsvrije specificatie

$\square$ Werk aanbesteden waarvoor $\mathrm{u}$ het maximaal beschikbare budget vooraf meedeelde aan gegadigden

$\square \quad$ Werk aanbesteden waarbij prestaties uit het verleden mede van invloed waren op de keuze van de aannemer

$\square \quad$ Werk aanbesteden waarbij u aannemers aan liet geven welke risico's ze zien en hoe ze denken die te managen

$\square \quad$ Werk aanbesteden waarbij de kwaliteit van projectleider en (hoofd) uitvoerder van de aannemer mede van invloed was op de keuze van de aannemer

$\square \quad$ Werk aanbesteden waarbij naast prijs ook kwaliteit van de aanbieding van invloed was op de keuze van de aannemer

$\square \quad$ Werk aanbesteden waarbij u de risico's die de aannemer beter kon dragen ook daadwerkelijk aan hem overdroeg

$\square \quad$ Werk aanbesteden waarbij u de performance van de aannemer volgde aan de hand van periodiek door hem zelf op te leveren "facts en figures"

$\square \quad$ Werk aanbesteden waarbij u bij de oplevering van dat werk een overall Performance toekende aan de aannemer, die tevens van invloed was op zijn kansen op toekomstig werk
Stellingen over effecten van PiPs safeguards i.r.t. Onzekerheid Opdrachtgevers

(ONZ - OG)

In te vullen door opdrachtgevers

Bij projecten die functioneel gespecificeerd aanbesteed worden,

${ }^{n r} \mathbf{1}$ beschik ik in mindere mate over informatie om het verloop van het project te kunnen voorspellen

$n r 2$ ben ik minder onzeker over de manier waarop we de vraag hebben geformuleerd

${ }^{n r} 3$ ervaar ik meer onzekerheid over de contractuele vastlegging van hetgeen overeen gekomen is

${ }^{n r} 4$ heb ik minder zorgen over onvoorziene gebeurtenissen

${ }^{n r} 5$ ervaar ik meer onzekerheid over de coöperatieve houding van de aannemer

nr 6 sterkt dat mijn vertrouwen in de geselecteerde aannemer

Als prestaties uit het verleden meegewogen hebben bij de aanbesteding,

$n r 7$ beschik ik over meer informatie om het verloop van het project te kunnen voorspellen

$n r \boldsymbol{8}$ ben ik minder onzeker over de manier waarop we de vraag hebben geformuleerd

${ }^{n r} 9$ ben ik minder onzeker over de contractuele vastlegging van hetgeen is overeengekomen

$n r 10$ ben ik minder onzeker over de coöperatieve houding van de aannemer 
${ }^{n r} \mathbf{1 1}$ sterkt dat mijn vertrouwen in de geselecteerde aannemer.

Als aannemers van te voren nagedacht hebben over risico's en hoe daarmee om te gaan,

$n r 12$ beschik ik over meer informatie om het verloop van het project te kunnen voorspellen

nr 13 ben ik minder onzeker over de manier waarop we de vraag hebben geformuleerd

$n r 14$ ben ik minder onzeker over de contractuele vastlegging van hetgeen is overeengekomen

${ }^{n r} 15$ heb ik minder zorgen over onvoorziene gebeurtenissen

${ }^{n r} \mathbf{1 6}$ ben ik minder onzeker over de coöperatieve houding van de aannemer

${ }^{n r} \mathbf{1 7}$ sterkt dat mijn vertrouwen in de geselecteerde aannemer.

Als de kwaliteit van sleutelfunctionarissen van invloed is geweest op het verkrijgen van werk,

${ }^{n r} \mathbf{1 8}$ beschik ik over meer informatie om het verloop van het project te kunnen voorspellen

${ }^{n r} 19$ heb ik minder zorgen over onvoorziene gebeurtenissen

$n r \mathbf{2 0}$ ben ik minder onzeker over de coöperatieve houding van de aannemer

$n r \mathbf{2 1}$ sterkt dat mijn vertrouwen in de geselecteerde aannemer.
Als behalve prijs ook kwaliteit van invloed is geweest op het verkrijgen van werk,

nr 22 beschik ik over meer informatie om het verloop van het project te kunnen voorspellen

$n r 23$ ben ik minder onzeker over de manier waarop we de vraag hebben geformuleerd

nr 24 ben ik minder onzeker over de contractuele vastlegging van hetgeen is overeengekomen

nr 25 heb ik minder zorgen over onvoorziene gebeurtenissen

nr 26 ben ik minder onzeker over de coöperatieve houding van de aannemer

$n r \mathbf{2 7}$ sterkt dat mijn vertrouwen in de geselecteerde aannemer

Als aannemers bij acceptatie van werk ook verantwoordelijk worden voor kosten, planning en kwaliteit van dat op te leveren werk,

$n r \mathbf{2 8}$ ben ik minder onzeker over de manier waarop we de vraag hebben geformuleerd

$n r \mathbf{2 9}$ ben ik minder onzeker over de contractuele vastlegging van hetgeen is overeengekomen

${ }^{n r} \mathbf{3 O}$ heb ik minder zorgen over onvoorziene gebeurtenissen

nr 31 ben ik minder onzeker over de coöperatieve houding van de aannemer

${ }^{n r} \mathbf{3 2}$ sterkt dat mijn vertrouwen in de geselecteerde aannemer 
Als aannemers bij oplevering van het werk een totaal oordeel wordt toegekend dat de kans op toekomstig werk beïnvloedt,

nr 33 ben ik minder onzeker over de manier waarop we de vraag hebben geformuleerd

${ }^{n r} \mathbf{3 4}$ ben ik minder onzeker over de contractuele vastlegging van hetgeen is overeengekomen

${ }^{n r} 35$ heb ik minder zorgen over onvoorziene gebeurtenissen

nr 36 ben ik minder onzeker over de coöperatieve houding van de aannemer

nr 37 sterkt dat mijn vertrouwen in de geselecteerde aannemer

Als ik tijdens de bouw beschik over "harde" data over de performance van de aannemer,

nr $3 \mathbf{8}$ beschik ik over meer informatie om het verloop van het project te kunnen voorspellen

${ }^{n r} 39$ heb ik minder zorgen over onvoorziene gebeurtenissen

${ }^{n r} \mathbf{4 O}$ sterkt dat mijn vertrouwen in de geselecteerde aannemer
Stellingen over effecten van PiPs safeguards i.r.t. Opportunistisch gedrag

Opdrachtnemers (OPP - oN)

In te vullen door opdrachtgevers

Bij functioneel gespecificeerde projecten:

$n r 1$ Vertonen aannemers na gunning in mindere mate 'claimgedrag'

${ }^{n r} 2$ ervaar ik in de praktijk coöperatiever gedrag van de aannemer

${ }^{n r} 3$ ervaar ik in de praktijk meer eigen initiatief van de zijde van de aannemer

${ }^{n r} 4$ ervaar ik dat aannemers makkelijker bereid zijn gemaakte fouten te herstellen

${ }^{n r} 5$ ervaar ik dat aannemers minder geneigd zijn onvolkomenheden in het bestek uit te buiten

Wanneer ik vooraf aangeef wat het maximaal beschikbare budget is:

$n r 6$ vertonen aannemers na gunning in mindere mate 'claimgedrag'

$n r 7$ ervaar ik in de praktijk een open en oprechte houding van de zijde van de aannemer

$n r \mathbf{8}$ ervaar ik dat aannemers minder geneigd zijn onvolkomenheden in het bestek uit te buiten

nr 9 heb ik minder last van laag inschrijven en achteraf proberen voordelen binnen te halen 
Als prestaties uit het verleden meegewogen hebben bij de aanbesteding:

$n r \mathbf{1 0}$ vertonen aannemers na gunning in mindere mate 'claimgedrag'

${ }^{n r} \mathbf{1 1}$ heb ik minder last van laag inschrijven en achteraf proberen voordelen binnen te halen

${ }^{n r} \mathbf{1 2}$ vertoont de aannemer na gunning in hogere mate coöperatief gedrag

${ }^{n r} \mathbf{1 3}$ tonen aannemers na gunning in hogere mate eigen initiatief

$n r 14$ zijn aannemers na gunning in hogere mate bereid gemaakte fouten te herstellen

${ }^{n r} 15$ ervaar ik dat aannemers minder geneigd zijn onvolkomenheden in het bestek uit te buiten

Als aannemers van te voren nagedacht hebben over risico's en hoe daarmee om te gaan:

nr 16 heb ik minder last van laag inschrijven en achteraf proberen voordelen binnen te halen

${ }^{n r} \mathbf{1 7}$ heb ik in de praktijk minder last van het inzetten van te laag geschoold personeel

${ }^{n r} \mathbf{1 8}$ ervaar ik in de praktijk coöperatiever gedrag aan de zijde van de aannemer

$n r 19$ zijn aannemers na gunning in hogere mate bereid gemaakte fouten te herstellen
Als de kwaliteit van sleutelfunctionarissen van invloed is geweest op het verkrijgen van werk:

$n r \mathbf{2 O}$ ervaar ik na gunning meer oprechtheid en openheid van de zijde van de aannemer

nr 21 ervaar ik na gunning in geringere mate 'claimgedrag'

nr 22 ervaar ik na gunning een meer coöperatieve houding aan de zijde van de aannemer

nr 23 ervaar ik na gunning meer eigen initiatief van de zijde van de aanneme

Als behalve prijs ook kwaliteit van invloed is geweest op het verkrijgen van werk,

nr 24 ervaar ik na gunning minder 'claim gedrag' van de aannemer

nr 25 ervaar ik na gunning meer openheid en oprechtheid van de aannemer

nr 26 zetten aannemers na gunning beter geschoold personeel in

$n r \mathbf{2 7}$ stellen aannemers zich na gunning coöperatiever op

nr 28 zijn aannemers na gunning makkelijker bereid gemaakte fouten te herstellen

nr 29 ervaar ik na gunning meer eigen initiatief van de aannemer 
Als aannemers bij acceptatie van werk ook verantwoordelijk worden voor kosten, planning en kwaliteit van dat op te leveren werk,

$n r \mathbf{3 0}$ zetten ze beter geschoold personeel in

nr 31 stellen aannemers zich na gunning coöperatiever op

nr 32 zijn aannemers na gunning makkelijker bereid gemaakte fouten te herstellen

nr 33 vertonen ze na gunning minder 'claim gedrag'

Als aannemers bij oplevering van het werk een totaal oordeel wordt toegekend dat de kans op toekomstig werk beïnvloedt,

${ }^{n r} 34$ vertonen aannemers tijdens de bouw minder 'claim gedrag'

nr 35 zetten aannemers tijdens de bouw beter geschoold personeel in

nr 36 ervaar ik na gunning meer eigen initiatief van de aannemer

nr 37 zijn aannemers tijdens de bouw makkelijker bereid gemaakte fouten te herstellen

nr 38 zijn aannemers er tijdens de bouw minder op uit onvolkomenheden in het bestek uit te buiten

nr 39 ervaar ik na gunning meer openheid en oprechtheid van de aannemer

Als ik tijdens de bouw beschik over 'harde' data over de performance van de aannemer,

${ }^{n r} \mathbf{4 0}$ ervaar ik na gunning minder 'claim gedrag' van de aannemer nr 41 zal de aannemer beter geschoold personeel inzetten

nr $\mathbf{4 2}$ stellen aannemers zich na gunning coöperatiever op

${ }^{n r} 43$ ervaar ik na gunning meer eigen initiatief van de aannemer

nr 44 ervaar ik na gunning meer oprechtheid en openheid van de zijde van de aannemer

nr 45 zijn aannemers tijdens de bouw makkelijker bereid gemaakte fouten te herstellen 


\section{Enquête opdrachtnemers (PiPSON)}

Geef hier aan in welke sector u overwegend actief bent. Kies s.v.p. de sector waarin $\mathrm{u}$ het meest actief bent als opdrachtgever:

$\square \quad$ Woningbouw

$\square \quad$ Utiliteitsbouw

$\square$ Grond en Weg en Waterbouw (GWw)

Hoeveel jaren ervaring heeft u in 'de Bouw' Kies s.v.p. één interval die het meest op u van toepassing is:

$\square \quad \mathrm{O}^{\mathrm{t}} / \mathrm{m} 5$ jaren

$\square \quad 6 \%$ m 10 jaren

$\square \quad 11 \mathrm{t} / \mathrm{m} 15$ jaren

$\square \quad$ Meer dan 15 jaren

Werkt u overwegend voor publieke- of private opdrachtgevers?

$\square \quad$ Overwegend publieke opdrachtgevers

$\square \quad$ Overwegend private opdrachtgevers

Is uw achtergrond overwegend:

$\square$ (bouw)technisch

$\square \quad$ Bedrijfskundig/economisch

$\square$ Juridisch

$\square \quad$ overig

Geef hier aan of $\mathrm{u}$ onderstaande aspecten in de praktijk al bent tegengekomen (al eerder mee gewerkt niet/nauwelijks/regelmatig/veel):

$\square \quad$ inschrijven op werk dat oplossingsvrij gespecificeerd was

$\square \quad$ inschrijven op werk waarvoor u vooraf geïnformeerd werd over het maximaal beschikbaar budget

$\square \quad$ inschrijven op werk waarbij prestaties uit het verleden mede van invloed waren op de kans het werk gegund te krijgen 
$\square$ inschrijven op werk waarbij u aan moest geven welke risico's u ziet en hoe $u$ denkt die te zullen managen

$\square \quad$ inschrijven op werk waarbij de kwaliteit van projectleider en (hoofd) uitvoerder mede van invloed waren op de kans het werk gegund te krijgen

$\square \quad$ inschrijven op werk waarbij naast prijs ook kwaliteit van invloed waren op de kans het werk gegund te krijgen

$\square \quad$ inschrijven op werk waarbij de opdrachtgever risico's die u beter kunt dragen ook daadwerkelijk aan u overdroeg

$\square \quad$ inschrijven op werk waarbij uw performance periodiek aan de hand van 'facts and figures' werd gevolgd

$\square \quad$ inschrijven op werk waarbij u een overall score werd toegekend bij oplevering, die tevens van invloed was op toekomstige kansen op werk
Stellingen over effecten van PiPs safeguards i.r.t. Onzekerheid Opdrachtnemers

(oNZ - ON)

In te vullen door opdrachtnemers

Als opdrachtgevers projecten functioneel gespecificeerd aanbesteden,

${ }^{n r} \mathbf{6}$ zie ik meer mogelijkheden een gezond rendement te kunnen maken

$n r 7$ ervaar ik grotere onzekerheid ten aanzien van de voor dat project benodigde kennis

$n r \mathbf{8}$ ervaar ik meer onzekerheid met betrekking tot het juist inschatten van het werk

${ }^{n r} \mathbf{9}$ maakt dat die aanbesteding voor mij onzekerder

$n r 10$ kan ik lastiger inspelen op onvoorziene gebeurtenissen

${ }^{n r} 11$ heb ik minder vertrouwen in een goede afloop van dat project

Als opdrachtgevers vooraf vertellen wat het maximaal beschikbare budget is dat aangewend kan worden,

${ }^{n r} 12$ zie ik meer mogelijkheden een gezond rendement te kunnen maken

${ }^{n r} 13$ ervaar ik minder onzekerheid met betrekking tot het juist inschatten van het werk

nr 14 maakt dat die aanbesteding voor mij minder onzeker

${ }^{n r} 15$ heb ik meer vertrouwen in een goede afloop van dat project 
Als opdrachtgevers bij aanbestedingen prestaties uit het verleden mee wegen,

${ }^{n r} \mathbf{1 6}$ zie ik meer mogelijkheden een gezond rendement te kunnen maken

${ }^{n r} 17$ ervaar ik minder onzekerheid ten aanzien van de voor dat project benodigde kennis

${ }^{n r} \mathbf{1 8}$ ervaar ik minder onzekerheid met betrekking tot het juist inschatten van het werk

nr 19 ben ik minder onzeker over het functioneren van de projectorganisatie

nr 20 maakt dat die aanbesteding voor mij minder onzeker

${ }^{n r} \mathbf{2 1}$ kan ik makkelijker inspelen op onvoorziene gebeurtenissen

${ }^{n r} 22$ heb ik meer vertrouwen in een goede afloop van dat project

Als ik als aannemer van te voren ben gevraagd na te denken over risico's en hoe daarmee om te gaan,

$n r \mathbf{2 3}$ zie ik meer mogelijkheden een gezond rendement te kunnen maken

nr 24 ervaar ik minder onzekerheid ten aanzien van de voor dat project benodigde kennis

nr 25 ervaar ik minder onzekerheid met betrekking tot het juist inschatten van het werk

nr 26 ben ik minder onzeker over het functioneren van de projectorganisatie nr 27 makkt dat een aanbesteding voor mij minder onzeker

nr 28 kan ik makkelijker inspelen op onvoorziene gebeurtenissen

$n r 29$ heb ik meer vertrouwen in een goede afloop van dat project

Als opdrachtgevers bij de aanbesteding van werk de kwaliteit van sleutelfunctionarissen mee wegen,

nr $\mathbf{3 0}$ zie ik meer mogelijkheden een gezond rendement te kunnen maken

nr $3 \mathbf{1}$ ervaar ik minder onzekerheid ten aanzien van de voor dat project benodigde kennis

nr 32 ervaar ik minder onzekerheid met betrekking tot het juist inschatten van het werk

nr 33 ben ik minder onzeker over het functioneren van de projectorganisatie

nr 34 maakt dat die aanbesteding voor mij minder onzeker

nr 35 kan ik makkelijker inspelen op onvoorziene gebeurtenissen

nr 36 heb ik meer vertrouwen in een goede afloop van dat project

Als opdrachtgevers naast prijs ook kwaliteit mee wegen bij het aanbesteden van werk,

nr 37 zie ik meer mogelijkheden een gezond rendement te kunnen maken

nr 38 ben ik minder onzeker over het functioneren van de projectorganisatie 
${ }^{n r} 39$ maakt dat die aanbesteding voor mij minder onzeker

$n r 40$ kan ik makkelijker inspelen op onvoorziene gebeurtenissen

${ }^{n r} \mathbf{4 1}$ heb ik meer vertrouwen in een goede afloop van dat project

Als opdrachtgevers mij als aannemer verantwoordelijk willen maken voor kosten, planning en kwaliteit van het project,

${ }^{n r} 42$ zie ik meer mogelijkheden een gezond rendement te kunnen maken

${ }^{n r} 43$ ervaar ik meer onzekerheid met betrekking tot het juist inschatten van het werk

${ }^{n r} 44$ ben ik minder onzeker over het functioneren van de projectorganisatie

${ }^{n r} 45$ maakt dat een aanbesteding voor mij minder onzeker

nr 46 kan ik makkelijker inspelen op onvoorziene gebeurtenissen

${ }^{n r} 47$ heb ik meer vertrouwen in een goede afloop van dat project
Stellingen over effecten van PiPs safeguards i.r.t. Opportunistisch gedrag Opdrachtgevers

(OPP - OG )

In te vullen door opdrachtnemers

Als opdrachtgevers een functioneel gespecificeerd project aanbesteden,

${ }^{n r} 1$ maak ik me zorgen over het open en eerlijk delen van beschikbare informatie

$n r 2$ houden ze star vast aan die functionele specificatie

${ }^{n r} 3$ maak ik me zorgen over openheid en eerlijkheid

Als opdrachtgevers vooraf vertellen wat het maximaal beschikbare budget is dat aangewend kan worden,

${ }^{n r} 4$ houden ze daar star aan vast

${ }^{n r} 5$ willen die toch voor een dubbeltje op de eerste rang zitten

Als opdrachtgevers bij aanbestedingen prestaties uit het verleden mee wegen

$n r 6$ maak ik me zorgen of dat wel open en eerlijk gebeurt

$n r 7$ maak ik me zorgen over de objectiviteit waarmee dat gebeurt

Als opdrachtgevers bij de aanbesteding van werk de kwaliteit van sleutelfunctionarissen mee wegen,

$n r \mathbf{8}$ maak ik me zorgen of dat wel open en eerlijk gebeurt

${ }^{n r} 9$ maak ik me zorgen over de objectiviteit waarmee dat gebeurt 
Als opdrachtgevers naast prijs ook kwaliteit mee wegen bij het aanbesteden van werk,

${ }^{n r} 10$ maak ik me zorgen over de objectiviteit waarmee dat gebeurt

${ }^{n r} 11$ maak ik me zorgen of dat wel open en eerlijk gebeurt

Als opdrachtgevers de aannemer verantwoordelijk willen maken voor kosten, planning en kwaliteit van het project,

${ }^{n r} 12$ maak ik me zorgen over het open en eerlijk delen van beschikbare informatie

${ }^{n r} 13$ willen die toch voor een dubbeltje op de eerste rang zitten

${ }^{n r} 14$ maak ik me zorgen over redelijke en flexibele opstelling van die opdrachtgevers

\section{over de auteur}

Joop van Duren werd op twee september 1959 geboren. In 1980 behaalde hij zijn hts diploma bouwkunde. Na enkele startersfuncties in de bouw maakte hij in 1986 de overstap naar de wereld van Facility Management. Hij bekleedde enkele functies in profit en not for profit omgevingen en studeerde bij het IBW Hogere Bedrijfskunde en General Management voor Hoger Kader. In 2002 maakte hij de overstap naar Zuyd Hogeschool als senior docent Facility Management. Vanaf 2003 participeerde hij in het Lectoraat FMInnovation alwaar hij kennis maakte met pips. Vanaf 2005 heeft dit promotieonderzoek een belangrijk deel van zijn werk gevormd. Sinds medio 2008 is hij op parttime basis actief als directeur Onderzoek en Ontwikkeling bij Inteon. Bij Zuyd Hogeschool zijn de belangrijkste aandachtsgebieden Inkopen en aanbesteden, strategisch Facility Management, coördinatie van het FM avondonderwijs en contracting activiteiten. Ook de European Master Facility Management in opleidingslocatie Maastricht staat onder zijn inhoudelijke leiding. Bij de ontwikkeling van de Aanbestedings Academie Limburg is Joop van Duren nauw betrokken. 


\section{reflectie op de rol van Kashiwagi bij PiPs in NL}

Dean Kashiwagi hanteert zijn Best Value benadering al geruime tijd in de USA. Hij is geïnteresseerd in het exporteren van zijn gedachtengoed. Nederland zou daarbij als bruggehoofd naar 'de rest' van het continent een belangrijke rol kunnen vervullen. De eerste contacten werden in 2003 gelegd met o.a. de Rijksgebouwendienst (George Ang) en UMC St Radboud (Felix van Baal). De contacten tussen Felix van Baal en Dean Kashiwagi enerzijds en Felix van Baal met Mark Erik Nota (Lector FMInnovation) anderzijds leidden ertoe dat een eerste voorstudie van pips werd gemaakt.

Dean Kashiwagi was in 2004 bereid tijdens een van zijn Nederlandse reizen deze voorstudie te bespreken. Hij was enthousiast over de manier waarop pips in die voorstudie werd geïnterpreteerd en beschreven. Daarnaast bestond de behoefte bij Felix van Baal de pips methodiek uit te testen. Dit werd ingegeven door een zekere onvrede vanuit de traditionele benadering van aanbestedingen en minder bevredigende resultaten die dat opgeleverd heeft. Om meer over pips te weten te komen zijn enkele bachelor en master studenten met deelvragen vanuit de voorstudie aan de slag gegaan. Tevens is begin 2005 deelgenomen aan de jaarlijkse pips conference in Phoenix, Arizona, usA. Master 
${ }^{117}$ Onder andere van Rws en Ballast Nedam. afstudeerder Andries van Bentum, twee projectmanagers van Bedrijf Huisversting van UMC St Radboud en de auteur van dit proefschrift hebben daar gesproken met opdrachtgevers en opdrachtnemers, gediscussieerd met Dean Kashiwagi en John Savicky en data meegekregen over het verloop van de eerste 400 Pips projecten in USA.

Bij de eerste Nederlandse pips praktijkcases heeft Dean Kashiwagi geen inhoudelijke rol gespeeld. Achterliggende oorzaak hiervoor is gelegen in het feit dat de trainingen (en daarmee samenhangende kosten) die Dean Kashiwagi wilde verzorgen voor de eerste drie onderhouds-

projecten disproportioneel groot en veel omvattend waren gezien de beperkte omvang en complexiteit van de aan te besteden opdrachten. De belangstelling voor pips groeide echter en op verschillende plaatsen werden initiatieven genomen. Rijkswaterstaat, enkele gemeentes, maar ook enkele aannemers wilden er kennis van nemen en de methodiek benutten bij het selecteren, contracteren en managen van hun onderopdrachtnemers en/of leveranciers.

Jeroen van der Rijt en Sicco Santema hebben toen het voorstel gedaan 'pips pioniers' bijeen te brengen in zogenoemde "type A meetings" om ervaringen uit te wisselen. Dean Kashiwagi heeft ook deelgenomen aan enkele van deze meetings en daarin zijn visie gegeven op de gehanteerde werkwijze, tips en adviezen verstrekt om valkuilen te voorkomen en nu en dan college gegeven.

Tijdens deze meetings is eenmaal aandacht besteed aan de drie onderhoudsprojecten van UMC St Radboud (17 november 2008) en tweemaal aandacht besteed aan de aanbesteding van het bergbezinkbassin ( 22 juni 2009 en 17 november 2009) voor de gemeente 's-Hertogenbosch. Op 27 september 2010 tenslotte, is de aanbesteding van de Holzstraat in Kerkrade onderwerp van gesprek geweest. Daarnaast zijn diverse concrete toepassingen ${ }^{117}$ die buiten het bestek van dit proefschrift vallen onder de loep genomen. De bijdragen en reflecties van Dean Kashiwagi bij deze type A meetings zijn betekenisvol geweest en hebben bijgedragen aan een beter begrip van de methodiek en effectievere toepassing ervan. 
